\title{
Excavations at the Early Caddo Period Mound Pond Site (41HS12) in Harrison County, Texas
}

\author{
Glenn T. Goode \\ Timothy K. Perttula \\ Heritage Research Center, Stephen F. Austin State University \\ Leslie L. Bush \\ Heritage Research Center, Stephen F. Austin State University \\ Shawn Marceaux \\ LeeAnna Schniebs
}

See next page for additional authors

Follow this and additional works at: https://scholarworks.sfasu.edu/ita

Part of the American Material Culture Commons, Archaeological Anthropology Commons, Environmental Studies Commons, Other American Studies Commons, Other Arts and Humanities Commons, Other History of Art, Architecture, and Archaeology Commons, and the United States History Commons

Tell us how this article helped you.

This Article is brought to you for free and open access by the Center for Regional Heritage Research at SFA ScholarWorks. It has been accepted for inclusion in Index of Texas Archaeology: Open Access Gray Literature from the Lone Star State by an authorized editor of SFA ScholarWorks. For more information, please contact cdsscholarworks@sfasu.edu. 


\section{Excavations at the Early Caddo Period Mound Pond Site (41HS12) in Harrison County, Texas}

Authors

Glenn T. Goode, Timothy K. Perttula, Leslie L. Bush, Shawn Marceaux, LeeAnna Schniebs, and Jesse Todd

Creative Commons License

(c) (1) (8)

This work is licensed under a Creative Commons Attribution-NonCommercial 4.0 International License 


\title{
Excavations at the Early Caddo Period Mound Pond Site (41HS12) in Harrison County, Texas
}

\author{
Glenn T. Goode, Timothy K. Perttula, Leslie L. Bush, Shawn Marceaux,
} LeeAnna Schniebs, and Jesse Todd

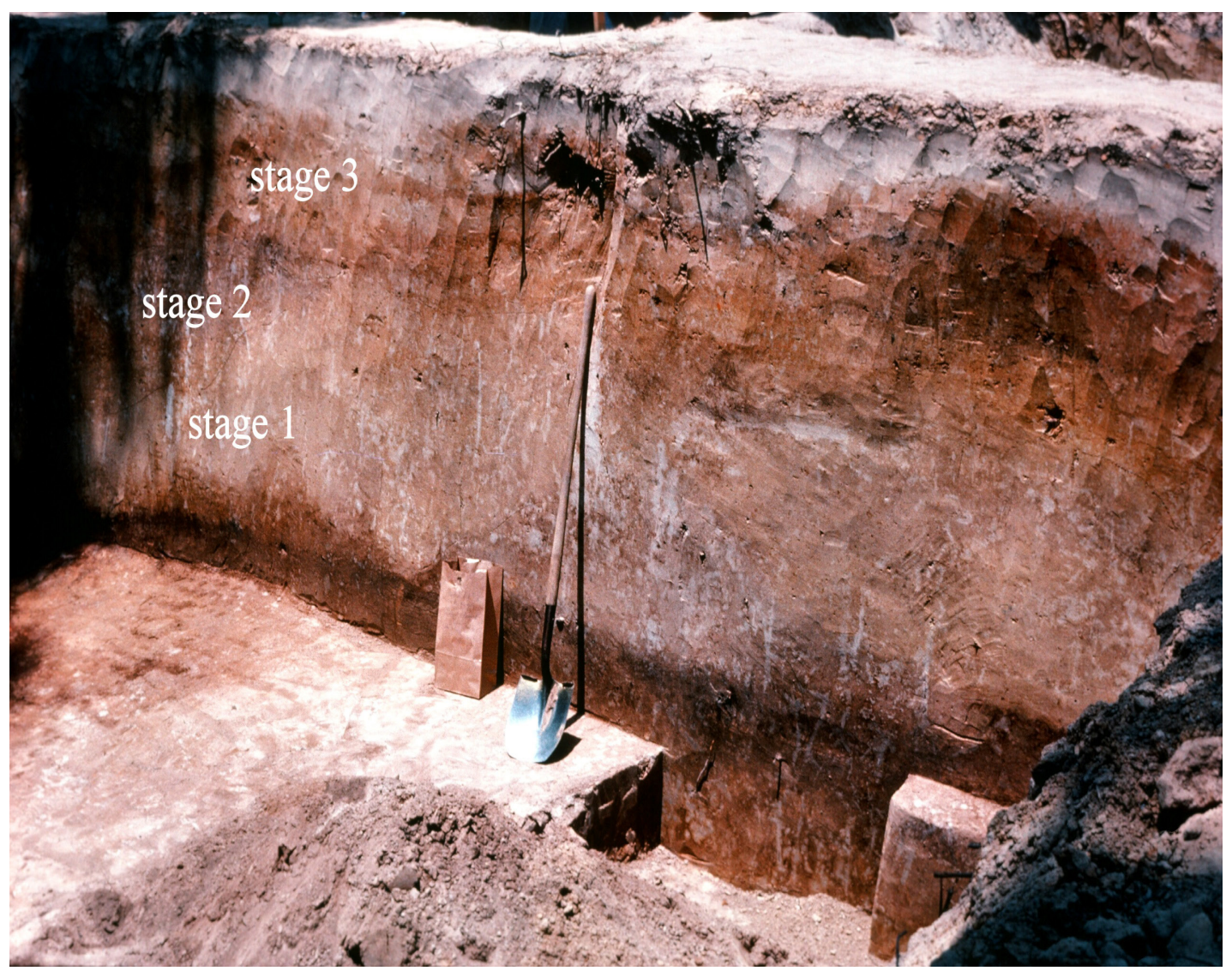

Special Publication No. 38

Friends of Northeast Texas Archaeology, Austin and Pittsburg 


\title{
Editor, Timothy K. Perttula 10101 Woodhaven Dr. Austin, Texas 78753 tkp4747@aol.com
}

Distribution, Bo Nelson, 344 CR 4154

Pittsburg, Texas 75686

RBoNelson@aol.com

\begin{abstract}
Cover art:
Cover art: View to the north of the north wall and floor of the Mound Pond block excavation after removal of the midden and the structure floor.
\end{abstract}

Copyright (C) 2015, Friends of Northeast Texas Archaeology

(Pittsburg and Austin) 


\section{Table of Contents}

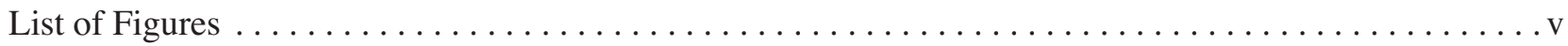

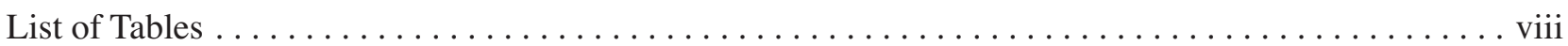

Chapter 1, Introduction, Ancestral Caddo Context, and Environmental Setting,

by Glenn T. Goode, Timothy K. Perttula, and Leslie L. Bush . . . . . . . . . . . . . . . 1

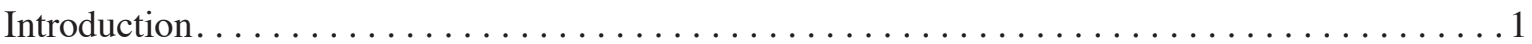

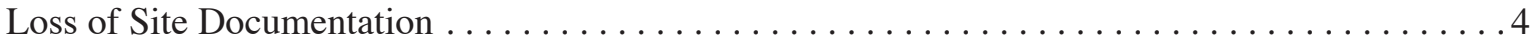

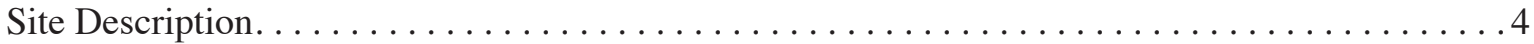

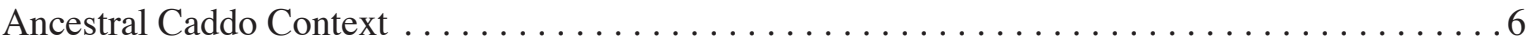

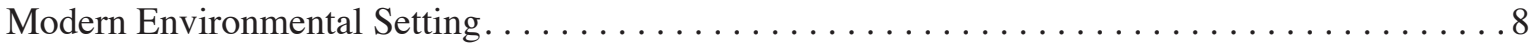

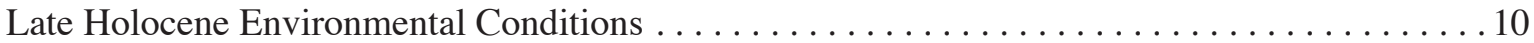

Chapter 2, Archaeological Investigations at the Mound Pond Site, by Glenn T. Goode . . . . . . . . . . 11

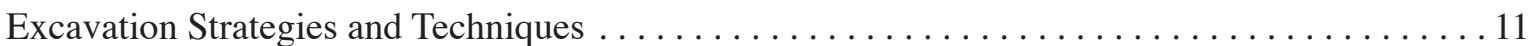

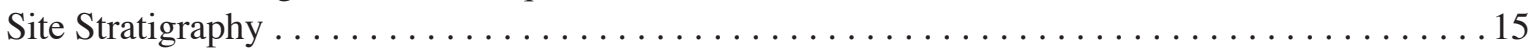

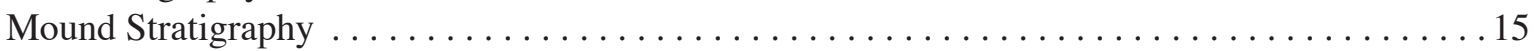

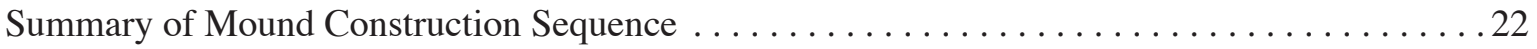

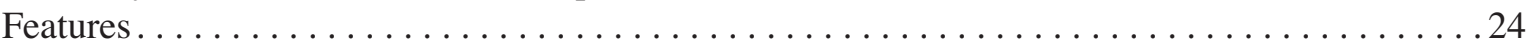

Chapter 3, Radiocarbon Dating, by Timothy K. Perttula ....................... 27

Chapter 4, Analysis of the Lithic Artifacts from the Mound Pond Site, by Glenn T. Goode . . . . . . . . . 31

Notable Attributes of the Mound Pond Lithic Assemblage . . . . . . . . . . . . . . . . 31

Lithic Raw Materials . . . . . . . . . . . . . . . . . . . . . . . . . . . 31

Diagnostic Tools, Non-Diagnostic Tools, and Tool Preforms $\ldots \ldots \ldots \ldots \ldots \ldots \ldots \ldots \ldots$

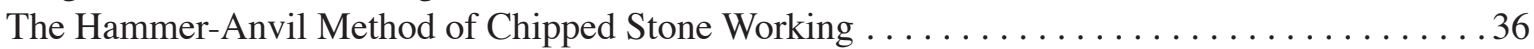

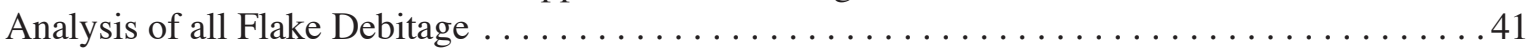

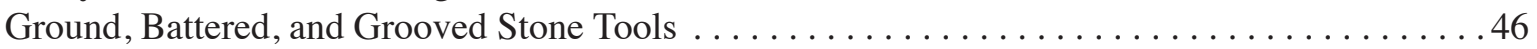

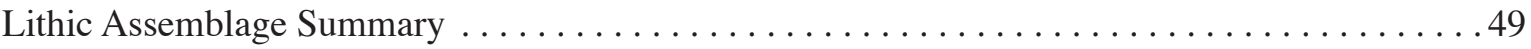

Chapter 5, Ceramic Vessel Sherds and other Clay Artifacts, by Timothy K. Perttula

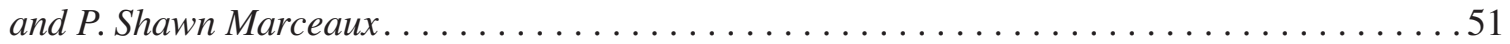

Plain Rim, Body, and Base Sherds from the Mound Pond site .................51

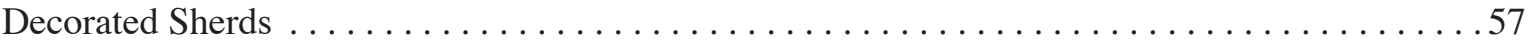

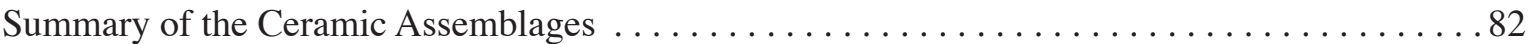

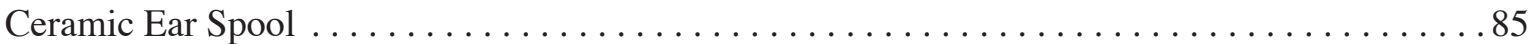

Burned Clay, Daub, and Mud Dauber Nests. . . . . . . . . . . . . . . . . . . . . 86

Chapter 6, Faunal Analysis from the Mound Pond Site: An Early Caddo Mound Site

in Harrison County, Texas, by LeeAnna Schniebs . . . . . . . . . . . . . . . . . . . . . . . . . . . 87

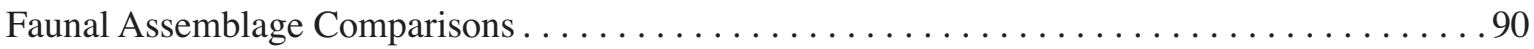


Chapter 7, Shell Analysis, by Jesse Todd . . . . . . . . . . . . . . . . . . . . . . . . .93

Chapter 8, Floral Remains from the 1977 Investigations at Mound Pond (41HS12),

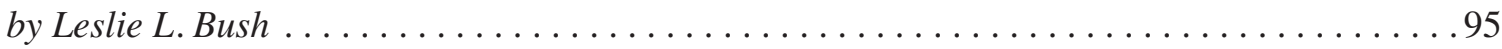

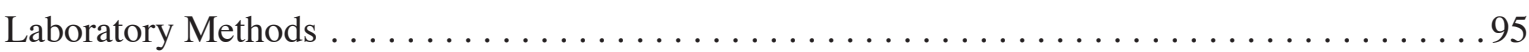

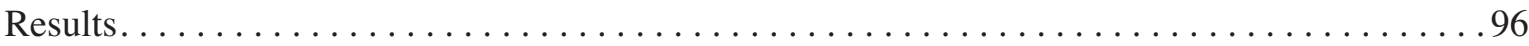

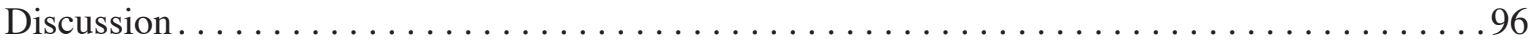

Chapter 9, Summary and Conclusions, by Glenn T. Goode and Timothy K. Perttula . . . . . . . . . . . . 101

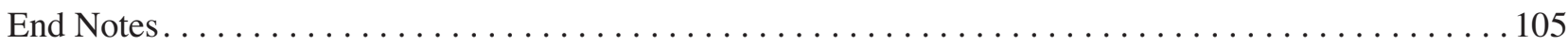

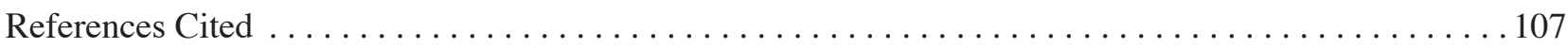

Appendix 1, Lot Numbers and Proveniences, Mound Pond Site $(41 \mathrm{HS} 12) \ldots \ldots \ldots \ldots \ldots \ldots \ldots$

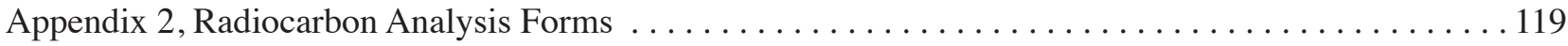

Appendix 3, Detailed Analysis of a Sample of Plain Sherds from the Mound Pond Site (41HS12), by P. Shawn Marceaux . . . . . . . . . . . . . . . . . . . . . . . . . 125

Appendix 4, Detailed Analysis of Decorated Sherds from the Mound Pond Site (41HS12),

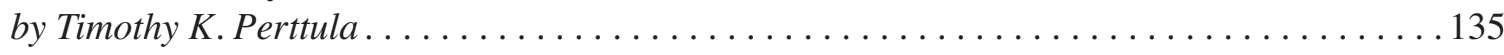




\section{List of Figures}

1. The location of the Mound Pond site in the East Texas Pineywoods $\ldots \ldots \ldots \ldots \ldots \ldots \ldots \ldots \ldots$

2. Clarence H. Webb in west trench observing north wall profile; Dave Brown to his left in hat; and Forrest Murphey standing behind wheelbarrow; view east $\ldots \ldots \ldots \ldots \ldots \ldots \ldots \ldots$

3. Excavation in the West Trench. Left to right: Rob Schleier (Kilgore, Texas), David C. Brown, Rodney Still, and Forrest Murphey; view east. . . . . . . . . . . . . . . 3

4. Forrest Murphey standing on the mound; view to the north... $\ldots \ldots \ldots \ldots \ldots \ldots \ldots \ldots \ldots$

5. View towards Area B from the top of the mound; view to the south. $\ldots \ldots \ldots \ldots \ldots \ldots \ldots \ldots$

6. Dave Brown digging in the North Trench at the northern margin of the mound; Mound

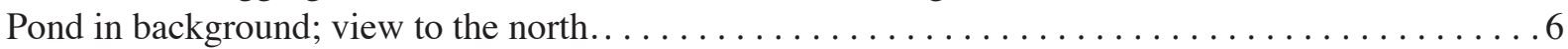

7. Schematic profile of the flat-topped mound at the Mound Pond site, redrawn from

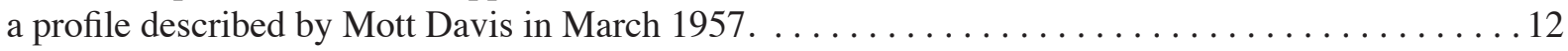

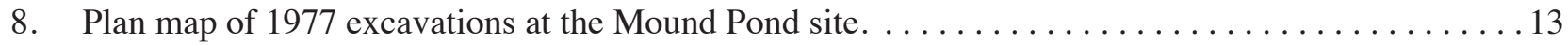

9. West trench, south wall profile: a, left hand side of the profile; $b$, right hand side

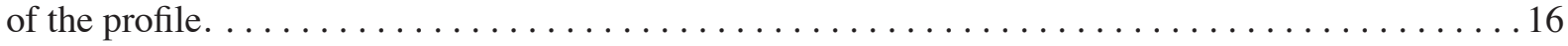

10. Representative site profile in West Trench, Unit N98/E98, south wall. $\ldots \ldots \ldots \ldots \ldots \ldots \ldots$

11. Block excavation, north wall profile: $a$, north wall; $b$, north and west walls $\ldots \ldots \ldots \ldots \ldots$

12. View west of the block excavation, north and west wall profiles; balk separating Block and West trench. . . . . . . . . . . . . . . . . . . . . . . . . . 19

13. West by northwest view of the block excavation in midden deposit and overlying erosional deposits in north and west walls. The floor is mainly of 2 x 2 m Unit N97/E111,

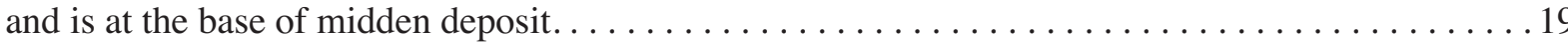

14. South wall of East trench, with east view of light-colored sandy berm partially

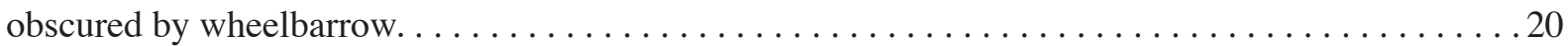

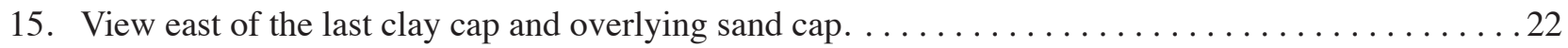

16. View to the northeast of Unit N95/E115, and a posthole and thermally discolored

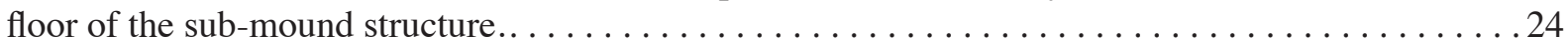

17. View to the north of the north wall and floor of block excavation after removal of the midden and the structure floor. This is a work shot without a scale, but the length

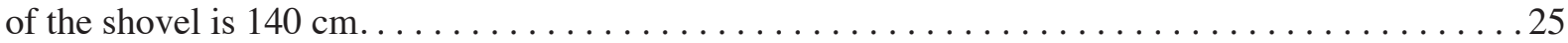

18. OxCal calibrations for Beta-303736 and Beta-303737 in sub-mound midden deposits at the Mound Pond site: a, Beta-303736; b, Beta-303737. Figure courtesy of Robert Z. Selden, Jr. . . . . . . . . . . . . . . . . . . . . . . . . . . . . . . . . . . . . . . . . . 29

19. Selected tools from Mound Pond: a, arrow point; b-c, arrow point preforms; d-h, modified flakes; i-j, chipped pebble fragments; k-1, ground stone tool fragments;

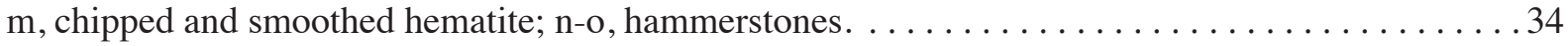

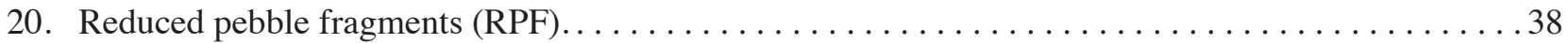




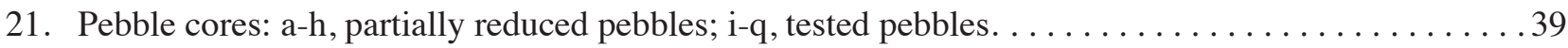

22. Hammer-anvil flake debitage: a-g, H-A 1 flakes; h-n, H-A 2 flakes; o-z, H-A 3 flakes;

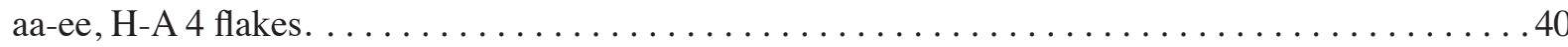

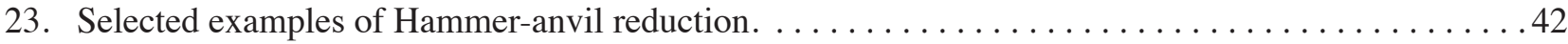

24. Ground stone tools from the Mound Pond site: a-c, pitted stones; d, smoothed/grooved stone.. . . . . 47

25. Red-slipped, engraved, and a finely-made Crockett Curvilinear Incised rim sherd: a, exterior red-slipped; b-c, Holly Fine Engraved; d, horizontal and hatched engraved diagonal zone rim; e, Crockett Curvilinear Incised rim sherd. Provenience: a, no provenience; b-c, N100 E108, lv. 2; d, N100 E102, 20-35 cm bs; e, N100 E112, 138-150 cm bs. . . . . . . . . . .60

26. Horizontal incised sherds from the midden and mound deposits. Provenience: a, N97 E111, 0-5 cm in midden; b, N100 E102, 20-35 cm bs; c, N100 E104, 20-35 cm bs. . . . . . .63

27. Horizontal, parallel, and parallel-diagonal incised sherds from the mound deposits. Provenience: a, N100 E100, 50-65 cm bs; b, N100 E108, 0-20 cm bs; c, N100 E102,

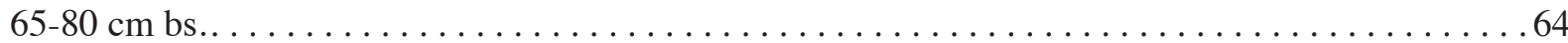

28. Incised and Incised-punctated sherds from the mound and midden deposits; a, diagonal incised; b, cross-hatched incised; c, chevron incised; d, diagonal incised on collared rim, and fingernail punctated rows. Provenience: a, N100 E108, 0-20 cm bs; b, N100 E106, level 1; c, N100 E108, 0-5 cm in midden; d, N100 E102, 65-80 cm bs. . . . . . . . . . . . . 65

29. Other incised decorative elements on sherds from the mound deposits: a, parallel and diagonal incised lines; $b$, panels filled with incised lines; $c$, diagonal incised rim panels and horizontal incised lines; diagonal incised body. Provenience: a, N100 E104, 35-50 cm bs; b, N100 E102, 20-35 cm bs; c, N100 E104, 20-35 cm bs.. . . . . . . . . . . . . . . . . .6 65

30. Fingernail punctated body sherds. Provenience: a, N100 E104, 35-50 cm bs; b, N100 E106, level 2 . . . . . . . . . . . . . . . . . . . . . . . . . . . . . . . . . . . . . . . . 67

31. Punctated and incised-punctated sherds from the mound deposits: a, tool punctated; b-c, curvilinear incised-punctated; d, horizontal incised lines over tool punctated rows; e, V-shaped punctated body sherds; $\mathrm{f}, \mathrm{V}$-shaped punctations and parallel incised lines. Provenience: a, N100 E100, 20-35 cm bs; b, N100 E102, 35-50 cm bs; c-d, N100 E106, level 2; e, N100 E108, 80-97 cm bs; f, N100 E110, 110-130 cm bs. . . . . . . . . . . 68

32. Incised-punctated rim sherds. Provenience: a-b, no provenience; c, N100 E108, 0-20 cm bs; d, N100 E108, 80-97 cm bs; e, N100 E102, 20-35 cm bs.. . . . . . . . . . . . . . . . 71

33. Incised-punctated body sherds from the mound deposits. Provenience: a-b, N100 E106, level 1. . . . . . . . . . . . . . . . . . . . . . . . . . . . . . . . . . . 72

34. Band punctated rim sherd from the mound deposits. Provenience: N100 E108, $85-100 \mathrm{~cm}$ bs... . . . . . . . . . . . . . . . . . . . . . . . . . . . . . . . . . . . 73

35. Coles Creek Incised sherds from the sub-mound midden deposits: a, Coles Creek Incised, var. Chase; b-c, Coles Creek Incised, var. Mott. Provenience: a, no provenience; b-c, N95 E115, 0-10 cm in midden. . . . . . . . . . . . . . . . . . . .76

36. Coles Creek Incised, var. Blakely carinated bowl. Provenience: N100 E110, midden.. . . . . . . . . 77 
37. Coles Creek Incised, var. Coles Creek and Coles Creek Incised, var. unspecified rim sherds in the midden deposits: a-b, Coles Creek Incised, var. Coles Creek; c, Coles Creek Incised, var. unspecified. Provenience: a, N97 E111, 0-5 cm in the midden; b, N97 E115, 0-10 cm

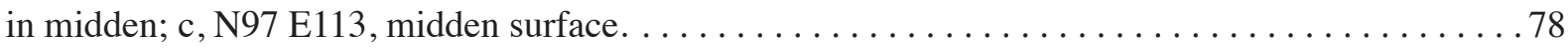

38. Coles Creek Incised, var. Coles Creek sherds with horizontal incised lines and lower impressed triangles. Provenience: a, N97 E115, 0-10 cm in midden; b, N97 E113, midden surface. . . . . . . . 79

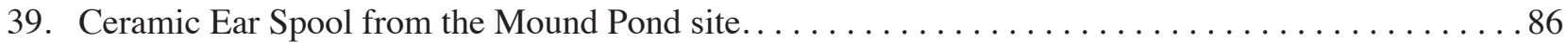

40. Acorn nut meat from Lot 93, N100 E110, sub-mound midden deposits, $175 \mathrm{~cm}$ bs . . . . . . . .96 


\section{List of Tables}

1. Vegetation communities near Mound Pond. Communities ordered from driest to wettest; dominant species in each are listed first (from Bezanson 2000; Diggs et al. 2006:89,

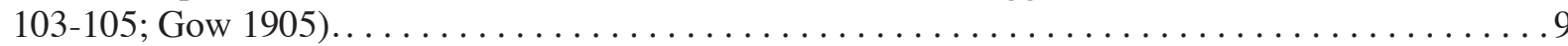

2. Radiocarbon Dates obtained from Beta Analytic from the Mound Pond site................28

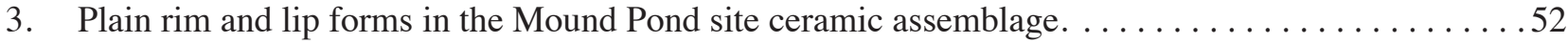

4. Temper classes in the plain ware in the Mound Pond site ceramic assemblage.............53

5. Firing conditions in the plain ware in the Mound Pond (41HS12) ceramic assemblage..........55

6. Surface treatment in the plain ware in the Mound Pond site ceramic assemblage...........56

7. Mean thickness of rim, body, and base sherds in the plain, utility, and fine wares. .........56

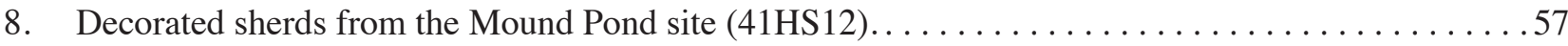

9. Fine ware sherds in the mound deposits at the Mound Pond site................... 58

10. Incised sherds in mound deposits at the Mound Pond site $\ldots \ldots \ldots \ldots \ldots \ldots \ldots \ldots \ldots \ldots \ldots$

11. Punctated, pinched, and punctated-pinched sherds in the mound deposits at the Mound Pond site. . . . . . . . . . . . . . . . . . . . . . . . . . . . . . . . . .67

12. Incised-impressed triangles, incised-pinched, incised-punctated, and band punctated sherds in the mound deposits at the Mound Pond site. . . . . . . . . . . . . . . . . . . . 69

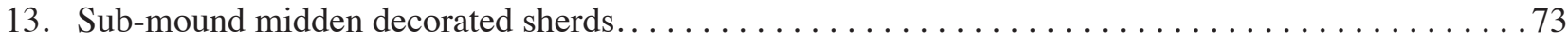

14. Area B decorated sherds......................................... 79

15. Temper and paste attributes in the decorated sherds from the Mound Pond site . . . . . . . . . 80

16. Firing conditions in the decorated sherds from the Mound Pond site $\ldots \ldots \ldots \ldots \ldots \ldots \ldots \ldots$

17. Sherd assemblage comparisons between the Mound Pond site and selected sites

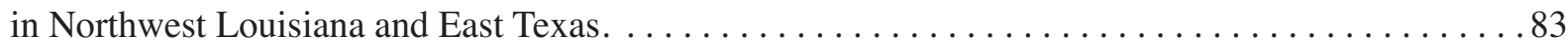

18. Summary of faunal taxonomic recovery from the Mound Pond site $(41 \mathrm{HS} 12) \ldots \ldots \ldots \ldots \ldots 7$

19. Distribution of Mound Pond site (41HS12) faunal remains by provenience . . . . . . . . . 88

20. Faunal assemblage comparisons between the mound and sub-mound midden deposits

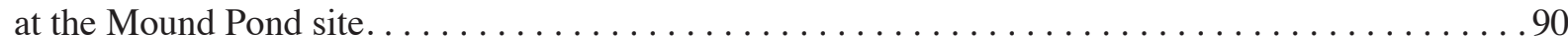

21. Faunal assemblage composition on other Caddo sites dating from ca. AD. 970-1200 . . . . . . . .91

22. Non-botanical items identified in carbon samples from the Mound Pond site (41HS12). . . . . . .95

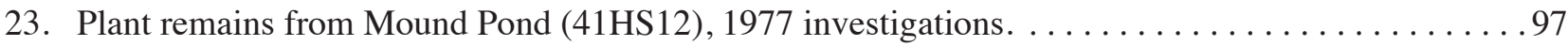

24. Proximate analysis of three edible tree nuts and corn meal per $100 \mathrm{~g}$ dry weight

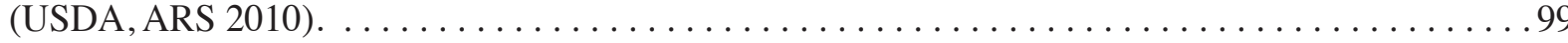




\section{Acknowledgments}

We would like to thank Lance Trask for preparing the figures and artifact photographs in this publication. We also thank Dr. Robert Z. Selden, Jr. for encouraging the completion of the manuscript, and we appreciate the comments on the manuscript by Jeff Girard and two anonymous reviewers. 



\title{
Chapter 1, Introduction, Ancestral Caddo Context, and Environmental Setting
}

\author{
Glenn T. Goode, Timothy K. Perttula, and Leslie L. Bush
}

\section{Introduction}

\section{Glenn T. Goode}

This publication summarizes major archaeological findings from the July 1977 excavations at the Mound Pond site (41HS12), in the Pineywoods of Harrison County, Texas. The site lies on the south, or right, bank of Big Cypress Creek in the upper reaches of Caddo Lake, approximately $4 \mathrm{~km}$ north of the village of Uncertain (Figure 1).

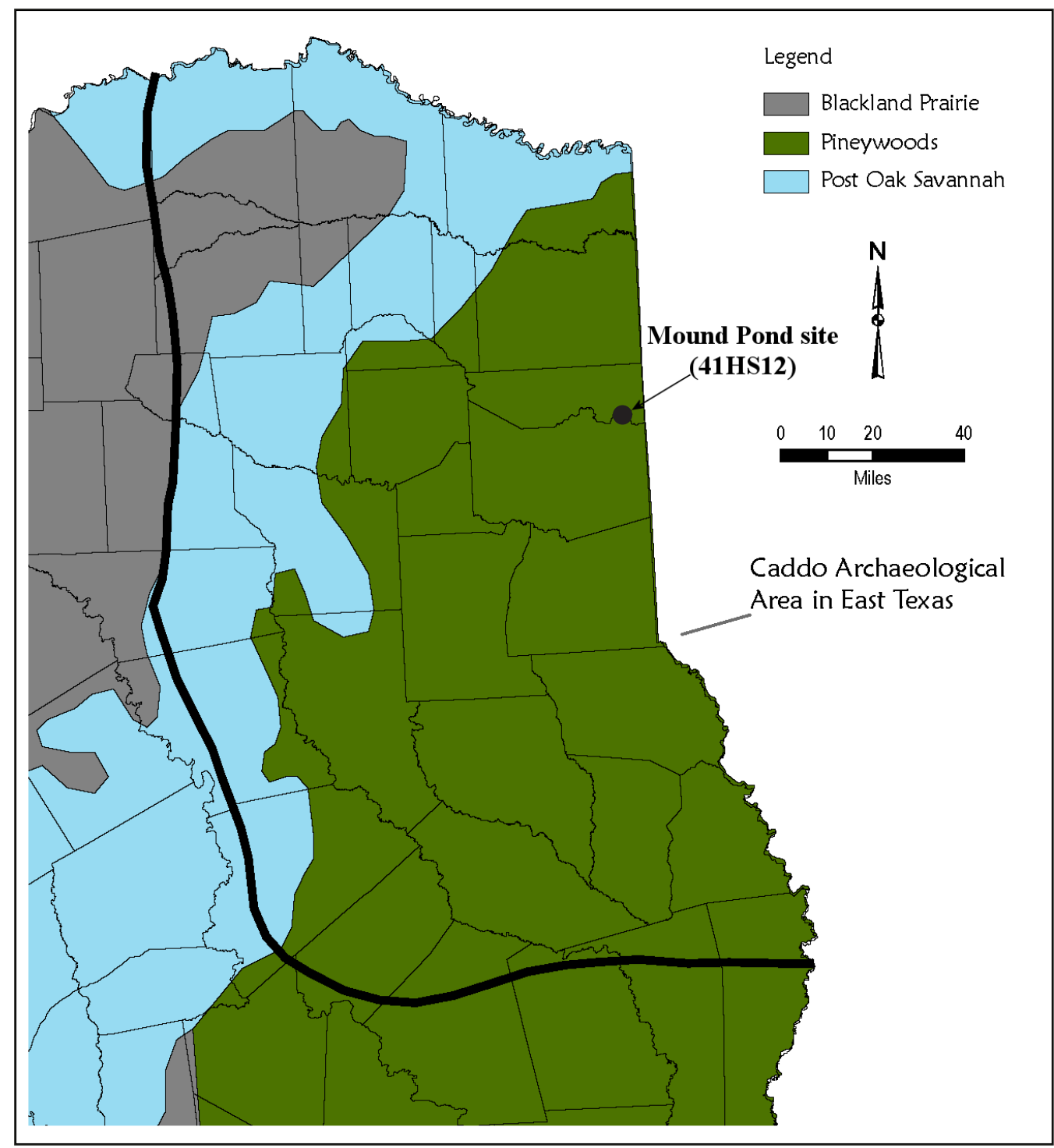

Figure 1. Location of the Mound Pond site in the northeastern Harrison County, Texas, Pineywoods. 
The Mound Pond Site was recorded by Dr. E. Mott Davis (The University of Texas at Austin) in the 1950s, during the time that he was conducting investigations at nearby Lake O' the Pines Reservoir. Early in 1977, Forrest Murphey, of Marshall, Texas, approached Glenn Goode about assisting in a test excavation of the large mound at the site. Mr. Murphey (now deceased) had been informed that the landowners intended to build a house on the site, and that the mound would be leveled to make a flat surface. Forrest was a knowledgeable avocational archaeologist of the region, having worked for several years with Dr. Clarence H. Webb and others at the Resch site (Webb et al. 1969) on Potters Creek south of Marshall, Texas.

In preparation for this undertaking, Goode conducted a file and library search at the Texas Archeological Research Laboratory (TARL) at the University of Texas at Austin, and discussed with Dr. Dee Ann Story (director of TARL) the feasibility of attempting such an effort. It was agreed that given the circumstances of impending destruction, an attempt to learn as much as possible in the three weeks available should be made. With Murphey and Goode being the only individuals committed to the entire project, and with no money to hire a crew, they turned to both the avocational and professional communities for assistance. East Texas residents David C. (Dave) Brown of Texarkana Junior College, and Rodney Still, of Kilgore, devoted significant time and expertise to the project. Dave had considerable archaeological experience in East Texas, having worked on several projects for Southern Methodist University in the 1960s. In 1974, Rodney had worked with Goode and the Texas Highway Department at the Marshall Powder Mill excavations (Luke 1978), and he was keenly interested in all aspects of Caddo and moundbuilder archaeology.

Notable authorities on Caddo archaeology who contributed to the project included Dee Ann Story, Clarence H. Webb, E. Mott Davis, Harry J. Shafer, and John E. (Jack) Keller. Jack's wife, Lynn Keller, accompanied him to the site. Shafer brought the Texas A \& M University (TAMU) archaeological field school to assist toward the end of the project; Ed Baxter and Steve Ursay of TAMU also assisted. Other professionals, mostly with some connection to TARL at that time, who participated included Molly Godwin, Jane Laurens, Virginia Christie, Gene P. Davis, Martha Hemphill, and Jean Hudson. Other volunteers included James L. Knox, Jr. of Atlanta, Texas, Kenneth and Sandy Campbell of Marshall, Texas, and Dave Brown's anthropology class from Texarkana College. In addition, a backhoe operator was hired to dig trenches in the mound. All together, approximately three dozen individuals contributed to the excavations (Figures 2-3).

The Mound Pond excavation was done during the first three weeks of July 1977 and, as such, falls within scopes of work usually described as test excavations. This was all the time that was available, and soon afterward the mound was essentially leveled and a structure on stilts built upon it.

Monetary donations were made by Dr. Dee Ann Story, Max Lale of Marshall, Dr. Clarence H. Webb of Shreveport, Louisiana, Ms. Solon Hughes, Curator of the Harrison County Museum, Wesley Ellis of Marshall Pottery, the Harrison County Commissioner's Court, Forrest Murphey, and Glenn T. Goode.

At the Memorial gathering for Dee Ann Story in February 2011, Timothy K. Perttula approached Glenn Goode about the status of the Mound Pond project. We agreed that an effort should be made to finally get the work published, despite the missing site documentation, and relying on gratis contributions by the report's primary authors. Shortly thereafter, we met at TARL, collected the artifacts and proceeded with the analysis. It is fair to say that without Dr. Perttula's interest, energy, and expertise the project would remain unfinished. Thus, a debt of gratitude is owed to Tim for insisting that this publication see the light of day. 


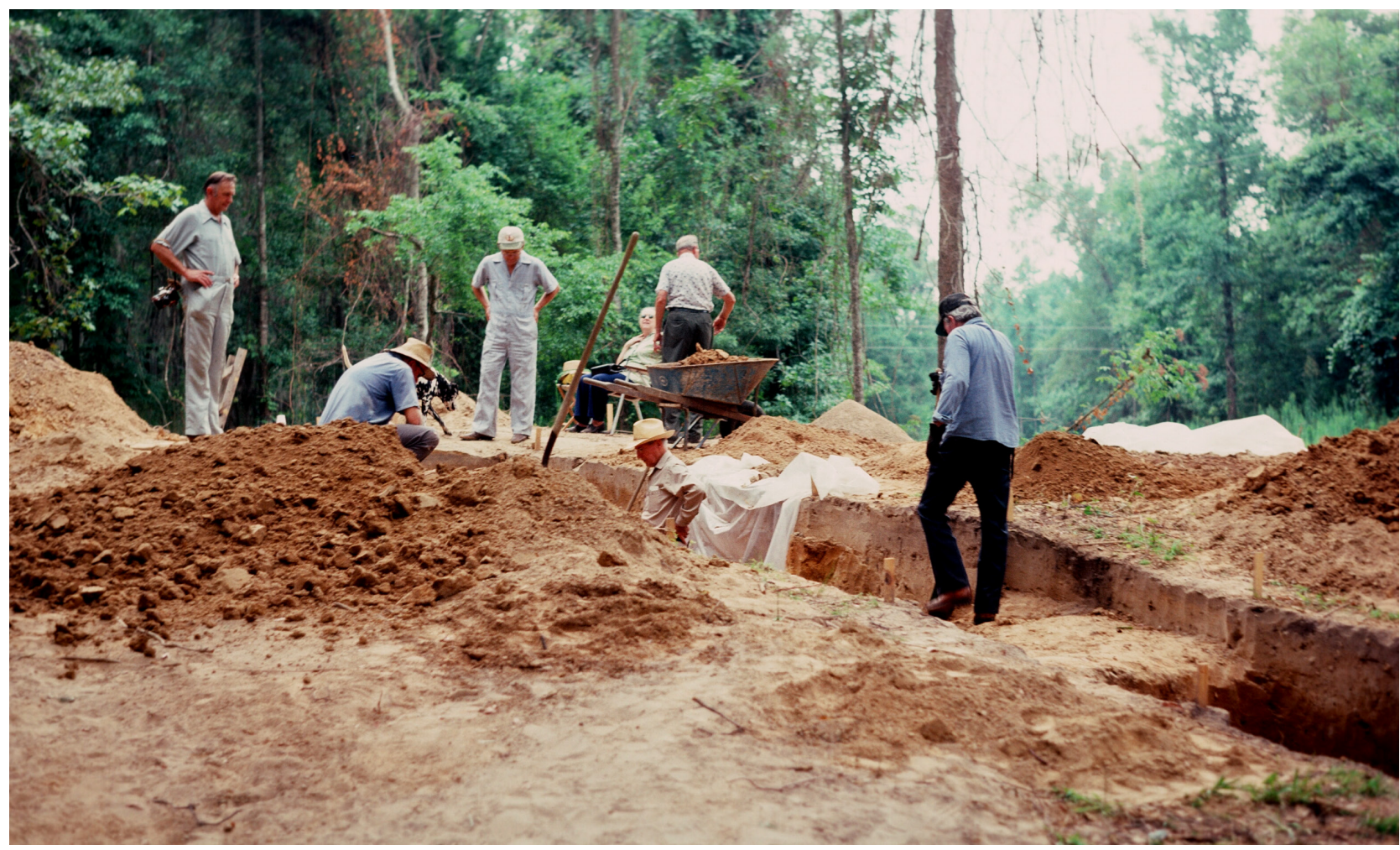

Figure 2. Clarence H. Webb in West Trench observing north wall profile; Dave Brown to his left in hat; and Forrest Murphey standing behind wheelbarrow; view east.

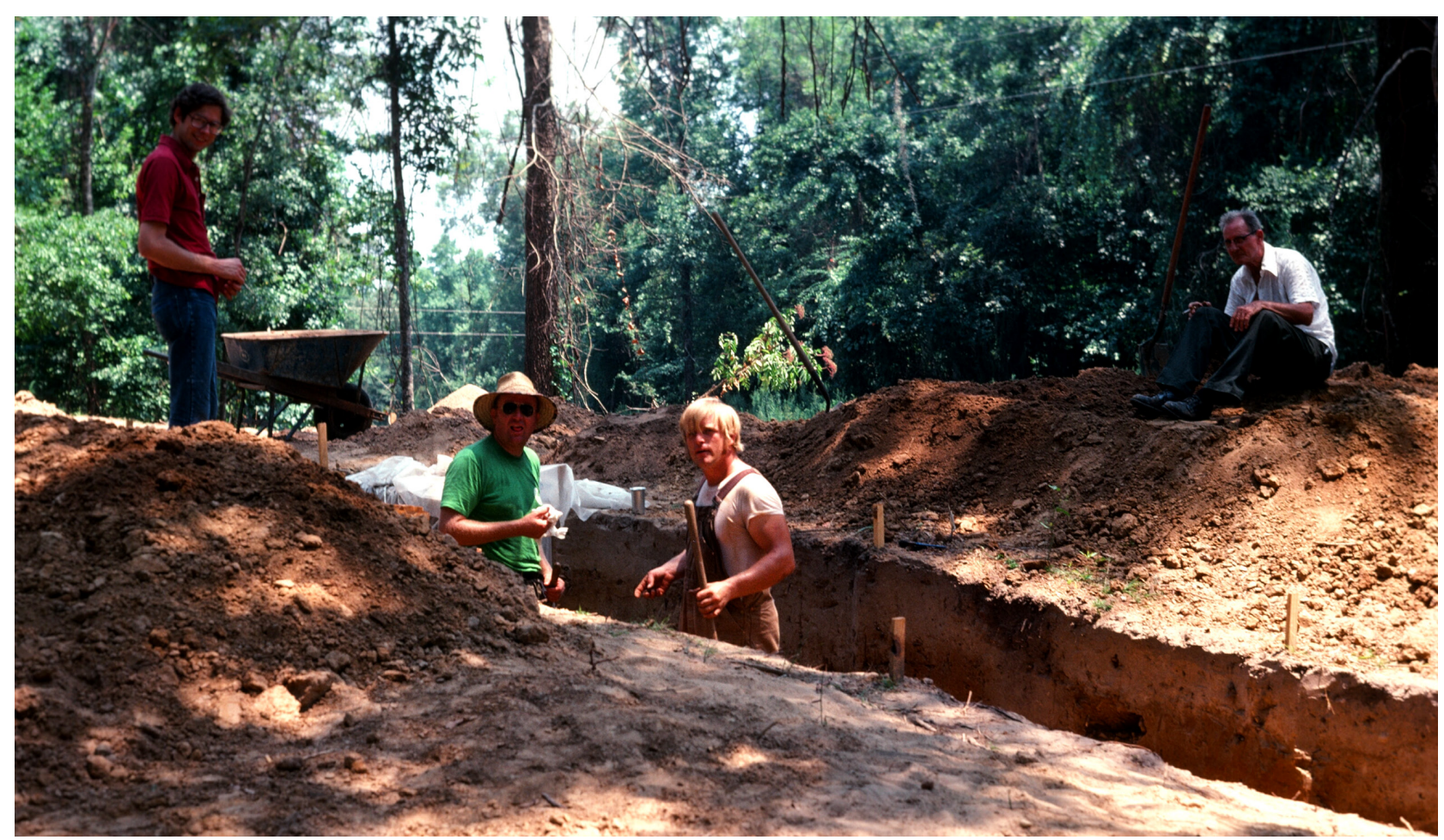

Figure 3. Excavation in the West Trench. Left to right: Rob Schleier (Kilgore, Texas), David C. Brown, Rodney Still, and Forrest Murphey; view east. 
This publication is dedicated to the memory of Forrest E. Murphey, David (Dave) C. Brown, E. Mott Davis, Dee Ann Story, and Clarence H. Webb, all of whom contributed to the excavation of the Mound Pond site.

\section{Loss of Site Documentation}

The primary reason for the considerable delay in reporting on the excavations at this site was the loss in 1979 of the greater portion of the site documentation. Included in the loss were almost all of the field notes, some of the photographs, the contour map log, and the photographic log, but not the artifacts, soil samples, or profiles. In the early 1990s, Goode and Dr. Darrel Creel (TARL) studied the profiles at TARL, before Dr. Creel submitted two samples for radiocarbon assay. At some unknown time since then, the profiles also disappeared and a concerted search did not find them. Therefore, this reporting lacks in many ways the records necessary to discuss details of profiles and mound construction.

In the early 1990s an inventory of the artifacts was made, but the great majority of the tools and more than half of the debitage could not be found for this analysis.

Fortunately, a sufficient number of color slides survived to provide an overview of the site excavations, as well as enough detail to present a general picture of the mound excavations. There is only one image of a portion of the north trench, very few of the east trench, and generally an insufficient number to reconstruct several of the profiles. As luck would have it, however, most of the slides are work shots instead of the final, cleaner, photographs that were taken. A single roll of black and white images also survived, but none contribute anything not better seen in the color slides.

\section{Site Description}

The investigated portion of the Mound Pond site lies on an alluvial terrace on the right, or south, bank of Big Cypress Creek (known as Big Cypress Bayou at this location). This is within $50 \mathrm{~m}$ of a small meander lake (a relict channel of Big Cypress Creek) known as Mound Pond, and approximately $300 \mathrm{~m}$ from a horseshoe bend in the creek to the northwest.

Cultural manifestations at the site consist of a low, flat-topped earthen mound (Figure 4) and habitation areas both near the mound and more than $50 \mathrm{~m}$ from it, including one area to the southwest designated as Area B (Figure 5). The mound was approximately $30 \mathrm{~m}$ in diameter and $1.85 \mathrm{~m}$ high at the mound center. The northern edge of the mound is near the margin of the first terrace of Big Cypress Creek, and from there it is approximately $25 \mathrm{~m}$ to Mound Pond (Figure 6). Near the center of the mound there was a shallow depression which Forrest Murphey knew to be a pothole. It reached below the bottom of the mound deposit, the last $50+\mathrm{cm}$ apparently having been dug with posthole diggers.

Other prehistoric occupations nearby, including another earthen mound, are approximately 200 to 300 $\mathrm{m}$ west of Mound Pond, at an area designated by the trinomial 41HS29. This site was visited by E. Mott Davis in 1957, and he described the mound as being conical, about 60-70 ft. in diameter (ca. 18.4-21.4 $\mathrm{m}$ ), 9-10 ft. in height (ca. 2.7-3.0 m), composed of light and dark sand, and without exposed cultural material (notes at TARL). Whether or not this mound is related to the one at Mound Pond is not known, but it seems likely that it is; the current condition of the 41HS29 earthen mound is not known. In any event, we do not discuss this mound at 41HS29 in this publication.

The ground surface of the terrace around Mound Pond is generally flat, but has small pimple mounds scattered here and there. The area was heavily wooded for the most part, although there had been 


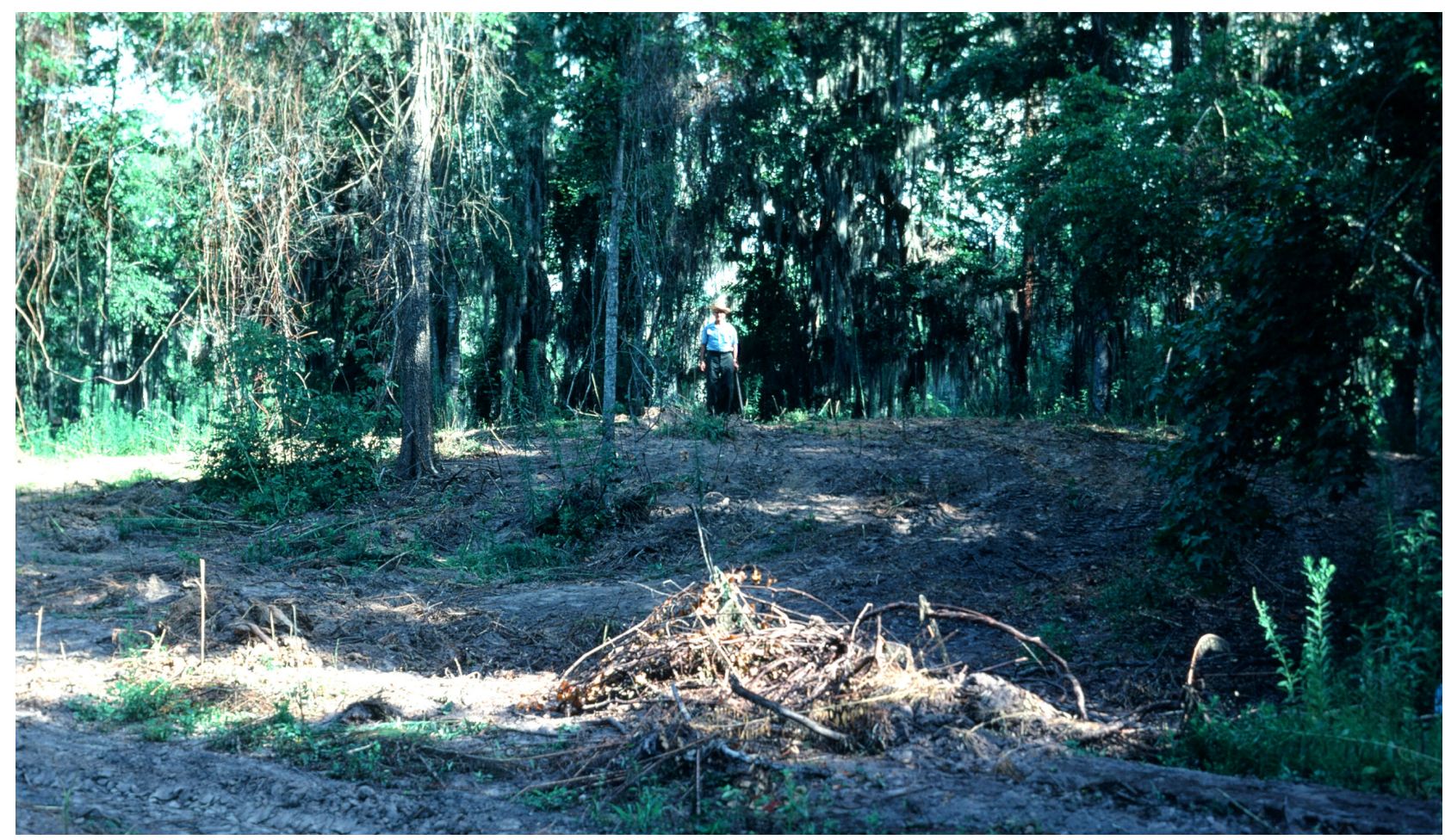

Figure 4. Forrest Murphey standing on the mound; view to the north.

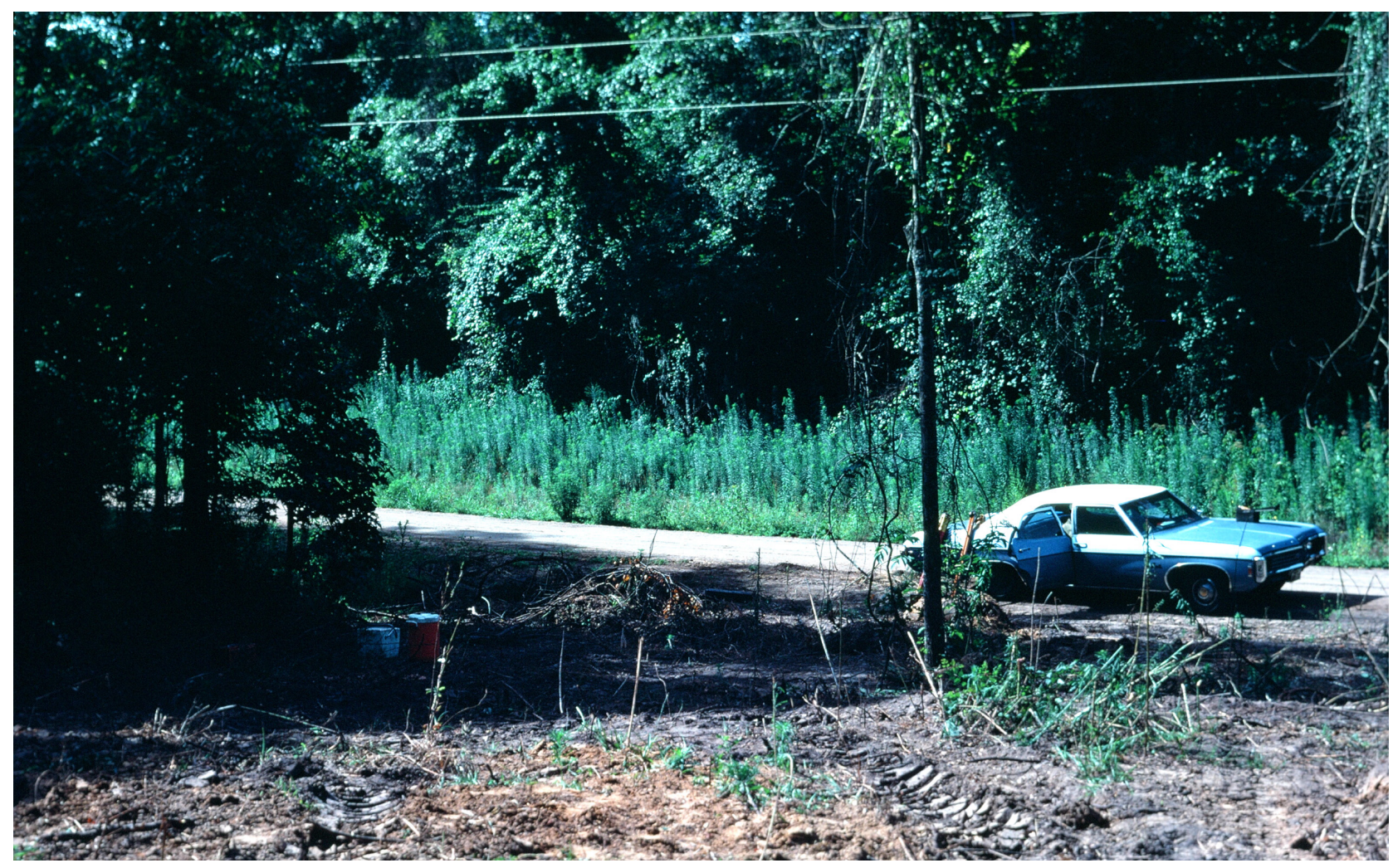

Figure 5. View towards Area B from the top of the mound; view to the south. 


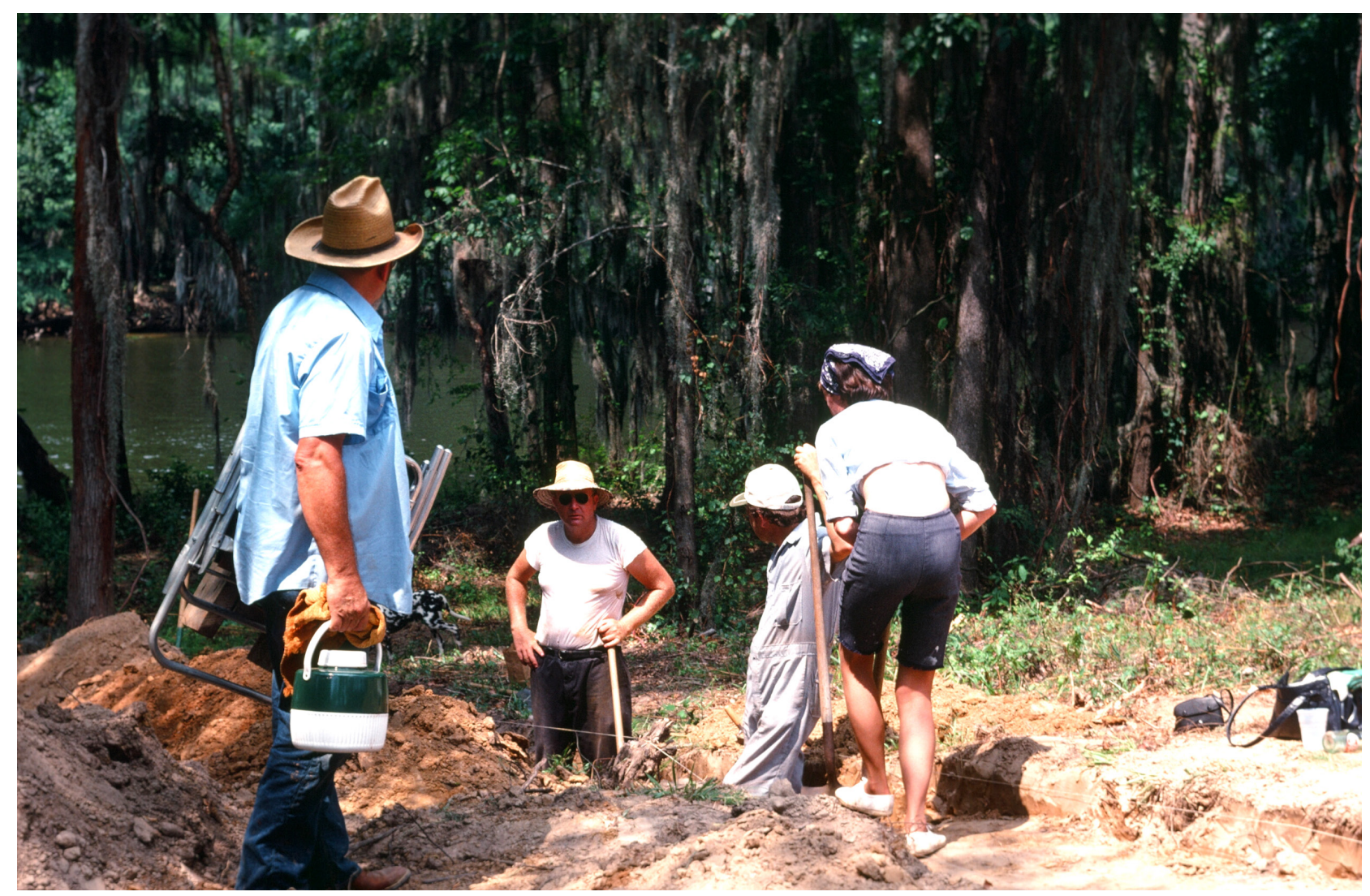

Figure 6. Dave Brown digging in the North Trench at the northern margin of the mound; Mound Pond in background; view to the north.

considerable clearing for houses near Mound Pond; there were structures both to the east and west, within $75 \mathrm{~m}$ of the mound. A narrow asphalt-paved road ran approximately $20 \mathrm{~m}$ south of the mound.

The profusion of woody vegetation at the site included elm, sweetgum, pine, holly, cane, and a variety of oaks, along with an abundance of underbrush. However, the mound itself was devoid of any sizeable woody vegetation, as it most likely had been cleared in recent years.

\section{Ancestral Caddo Context}

\section{Timothy K. Perttula}

The Mound Pond site is one of only a few excavated Early Caddo period mound sites in the region where the findings from archaeological investigation have been studied and published. These few other ancestral Caddo mound sites, each with multiple mounds, include the George C. Davis site (41CE19) on the Neches River (Story 1981 (ed.), 1997, 1998, 2000), the Boxed Springs site (41UR30) on the Sabine River (Perttula and Wilson 2000; Perttula 2011 (assembler); Shafer 2011), the Hudnall Pirtle site (41RK4) on the Sabine River (Bruseth 1991; Bruseth and Perttula 2006), and the James Pace site (16DS268) on the Sabine River (Girard 2014), the Mounds Plantation site (16CD12) on the Red River (Girard 2012; Webb and McKinney 1963, 1975), and the Gahagan site (16RR1) on the Red River (Emerson and Girard 2004; Webb and Dodd 1939). 
Caddo sites of this age are situated primarily on elevated landforms (alluvial terraces and rises, natural levees, and upland edges) adjacent to the major streams, as well as along minor tributaries and spring-fed branches. Proximity to arable sandy loam soils was preferred by Caddo peoples for settlement locations, presumably because of good drainage for habitation, and for cultivation purposes.

The majority of these Caddo sites are:

permanent settlements that have evidence of the structures, including posts, pits, and features marking their residency, along with the cemeteries and graves where the dead were buried; the middens where the animal and plant food refuse was discarded amidst broken stone tools and pottery vessels; and the material remains of tools and ceramics used in the procurement and processing of the bountiful resources of the region. They represent the settlements of Caddoan [sic] communities and sociopolitical entities, and the civic-ceremonial centers that were their focus (Perttula 1993:125).

The distribution of Caddo settlements across the landscape suggests that all habitats were used to some extent, either intensively as locations for the sedentary communities and farmsteads (that may have been occupied for single or multiple generations), or periodically by groups in logistical camps where specific natural resources could be procured by the Caddo in bulk (i.e., hardwood mast or stands of wild plants). Along the Red River, and probably on the other large streams or rivers in the Pineywoods, a particular focus of settlement was along natural levees in recently abandoned meander belts, and these habitats "served as an ideal context for a dispersed community" in a major floodplain landscape (Girard 1997:156).

The most common types of Caddo settlements in the region during these periods of time appear to be small year-round hamlets and farmsteads with circular to rectangular structures. These settlements sometimes occur in association with small household cemeteries, and occasionally with a larger cemetery (> 10 burials). Larger communities (covering more than 10 acres) have also been recognized that occur in association with mound centers, such as the large settlements at George C. Davis, Boxed Springs, and Hudnall-Pirtle. Shaft burials of high status individuals have been documented in mound contexts at George C. Davis (Story 1997, 1998, 2000) and a few other mound centers (such as Washington Square, Boxed Springs, and Sanders [41LR2]; see Corbin and Hart 1998; Hamilton 1997), and they also occur in non-mound contexts at several sites along the Red River during this period of time (see Bruseth 1998).

Certainly the most thoroughly studied Early Caddo period site in the East Texas region is the George C. Davis site, a large village and mound center on the Neches River. Calibrated radiocarbon dates from village contexts establish that the site was occupied beginning by the mid-9th century A.D., and then was continuously settled to the end of the 13th century A.D. (Story 2000). A large number of structures were built on, and adjacent to, Mound A, and the extensive structure rebuilding there indicates that particular restricted area was preferred for settlement by the Caddo. Geophysical surveys in the village have also documented a wide distribution of households there (Creel et al. 2004; Walker 2009). Calibrated dates from a few contexts suggest that the George C. Davis site was inhabited as late as ca. A.D. 1300 (see Story 1997, 2000), some time after the Mound Pond site was abandoned. There were three mounds at the Davis site, including Mound A (flat-topped platform), Mound C (burial mound) built over a large premound burial pit in the 10th century A.D. and containing an estimated 25-30 elite burial pits, and Mound B (flat-topped platform) constructed about A.D. 1200 or slightly earlier (Story 1997, 1998).

Both temple and burial mounds were built by these Pineywoods Caddo groups. The larger sites are important civic-ceremonial centers containing multiple mounds and associated villages, and 
these generally date after ca. A.D. 900; the smaller mounds at sites such as Mound Pond appear to represent mounds built over temple structures or other specialized buildings that were periodically burned, destroyed, and covered over with mound fill (see Trubitt 2009). The multiple mound centers are rather evenly spaced along the Red River, Sabine River, and Big Cypress Bayou, and those that are contemporaneous may represent hierarchical systems of an "integrated...regional network of interaction and redistribution" (Thurmond 1990:234). The distribution, number, and spacing of mound centers, particularly the sites with multiple mounds, in East Texas and adjoining parts of southwestern Arkansas and northwestern Louisiana clearly indicates that the Caddo peoples who built and used these mounds were integrated into societies of considerable socio-political complexity. Along with other Early Caddo period mound centers, the study of the archaeology of the Mound Pond site can contribute to a better understanding of "multi-community polities in the Caddo Area" (Girard 2014:79) as well as how the development of the mound at the site is related to the emergence of complex Caddo societies at both local and broader regional scales.

These ancestral Caddo groups seem to have been horticulturists, cultivating maize and squash, along with several kinds of native seeds (Perttula 2008c), gathered nuts and tubers/storage roots, and were proficient hunters of deer, fish, and many other animal species. The available paleobotanical and bioarchaeological evidence (including stable carbon isotopes on human remains from the Caddo area; see Wilson 2012) does not indicate, however, that Caddo groups became dependent or reliant upon maize and other domesticated crops until after about A.D. 1300 (Wilson and Perttula 2013). By ca. A.D. 1450, maize comprised more than $50 \%$ of the diet of many Caddo groups.

\section{Modern Environmental Setting}

\section{Leslie L. Bush}

The site lies on a terrace overlooking Big Cypress Creek, just south of what is now Mound Pond in northern Harrison County near Caddo Lake (see Figure 1). Artifacts indicate that the Caddo occupation occurred about A.D. 1000, if not later during the Early Caddo period.

Caddo Lake as it appears today is a recent phenomenon, shaped in part by dams constructed in the 20th century. Caddo Lake was present when 19th century European settlers arrived, however, and it was sometimes referred to as "Fairy Lake" or "Ferry Lake" in these accounts (Diggs et al. 2006:151). Current theory holds that Caddo Lake is a drowned floodplain created by the Great Raft that formed on the Red River over the course of the 18th century. Fred Dahmer, a long-time resident in the Caddo Lake area, is of the opinion that prior to the Great Raft, Caddo Lake was not a true lake but a "system of creeks, ponds, lakes, and swamps interspersed with islands and hillocks of dry ground. In the rainy season there were good-sized lakes; in the dry season it was a large swamp" (Dahmer 1995:4).

Certainly the wetter environments associated with Big Cypress Creek would have included floodplains, levees, and back swamps. The climax upland vegetation was characterized by shortleaf pine communities before extensive logging in the late 19th century. Mixed deciduous-loblolly pine communities were found on steep slopes and along tributary streams where they were somewhat protected from the forest fires that ensured the dominance of shortleaf pines and oaks in the uplands. Vegetation typically associated with these environments is listed in Table 1. 
Table 1. Vegetation communities near Mound Pond. Communities ordered from driest to wettest; dominant species in each are listed first (from Bezanson 2000; Diggs et al. 2006:89,103-105; Gow 1905).

\begin{tabular}{|c|c|}
\hline Environment & Typical vegetation \\
\hline Forested Uplands & $\begin{array}{l}\text { Shortleaf pine (Pinus echinata) } \\
\text { White ash (Fraxinus americana) } \\
\text { Spanish oak (Quercus falcata) } \\
\text { Black oak (Quercus velutina) } \\
\text { Post oak (Quercus stellata) } \\
\text { Blackjack oak (Quercus marilandica) } \\
\text { Hickory (Carya spp.) } \\
\text { Pecan (Carya illinoinensis) } \\
\text { Sassafras (Sassafras albidum) } \\
\text { Sweetgum (Liquidambar styraciflua) }\end{array}$ \\
\hline Slopes and coves & $\begin{array}{l}\text { Loblolly pine (Pinus taeda) } \\
\text { White oak (Quercus alba) } \\
\text { Southern red oak (Quercus falcata) } \\
\text { Black hickory (Carya texana) } \\
\text { Sweetgum (Liquidambar styraciflua) } \\
\text { Black gum (Nyssa sylvatica) } \\
\text { Water oak (Quercus nigra) } \\
\text { Black cherry (Prunus serotina) } \\
\text { Beech (Fagus grandifolia) } \\
\text { Elm (Ulmus spp.) } \\
\text { Red maple (Acer rubrum) } \\
\text { Magnolia (Magnolia grandiflora) } \\
\text { American holly Ilex opaca) } \\
\text { Sassafras (Sassafras albidum) } \\
\text { American beautyberry (Callicarpa americana) } \\
\text { Farkleberry (Vaccinium arboretum) } \\
\text { Virginia creeper (Parthenocissus quinquefolia) } \\
\text { Muscadine grape (Vitis rotundifolia) }\end{array}$ \\
\hline Regularly inundated levees & $\begin{array}{l}\text { Loblolly pine (Pinus taeda) } \\
\text { Water oak (Quercus nigra) } \\
\text { Sweetgum (Liquidambar styraciflua) } \\
\text { Willow oak (Quercus phellos) } \\
\text { Laurel oak (Quercus laurifolia) } \\
\text { Overcup oak (Quercus lyrata) } \\
\text { Cane (Arundinaria gigantea) }\end{array}$ \\
\hline
\end{tabular}


Table 1. Vegetation communities near Mound Pond, cont.

\begin{tabular}{|c|c|}
\hline Seasonally flooded river floodplains & $\begin{array}{l}\text { Willow oak (Quercus phellos) } \\
\text { Laurel oak (Quercus laurifolia) } \\
\text { Swamp chestnut oak (Quercus michauxii) } \\
\text { Sweetgum (Liquidambar styraciflua) } \\
\text { American elm (Ulmus americana) } \\
\text { Swamp tupelo (Nyssa biflora) } \\
\text { Red maple (Acer rubrum) } \\
\text { Deciduous holly (Ilex decidua) } \\
\text { American snowbell (Styrax americana) } \\
\text { Mayhaw (Crataegus opaca) }\end{array}$ \\
\hline Semi-permanently flooded swamps (shallow) & $\begin{array}{l}\text { Water elm (Planera aquatica) } \\
\text { Carolina ash (Fraxinus caroliniana) } \\
\text { Black willow (Salix nigra) } \\
\text { Bald cypress (Taxodium distichum) }\end{array}$ \\
\hline Semi-permanently flooded swamps (deep) & $\begin{array}{l}\text { Bald cypress (Taxodium distichum) } \\
\text { Water tupelo (Nyssa aquatica) } \\
\text { Yellow-pond lily (Nuphar lutea) } \\
\text { Buttonbush (Cephalanthus occidentalis) }\end{array}$ \\
\hline
\end{tabular}

\section{Late Holocene Environmental Conditions}

\section{Timothy K. Perttula}

Changes in solar radiation inferred from atmospheric delta C14 variation (Bradley et al. 2003:Figure 6.13 ) in the Late Holocene (ca. 2000-750 years B.P.) provide a useful climatic proxy for environmental conditions, especially mean annual temperature and precipitation, during the time when the Mound Pond site was occupied (ca. 750-1100 years B.P.). One of the colder and drier periods occurred at 700 years B.P. (Wolf climatic minimum), but there were other peaks in cooler and drier temperatures during the Medieval minimum at ca. 1200 and 1150 years B.P, and then again at 900 years B.P. during the Ort minimum. Otherwise, it appears that climatic conditions during the time of the Mound Pond occupation were generally equitable, and not often characterized by dramatic and profound fluctuations. Viau et al. (2002) indicates that this part of the Late Holocene was one of climatic amelioration with peaks and valleys in temperature and precipitation, culminating in a warm period about 1000 years B.P.

Tree-ring or dendrochronological analysis of cypress trees and logs also indicates that droughts were not uncommon in the Late Holocene in East Texas, as there were numerous wet and dry spells between ca. A. D. 1000-1700. Wetter and warmer conditions were two times as likely to occur as drier and droughty conditions in the earlier part of the period (perhaps during the latter part of the temporal interval when the Mound Pond site was occupied), beginning after A.D. 900, but by the early 15th century, drier years were much more common (Perttula 2008a:72 and Table 3-1). 


\title{
Chapter 2, Archaeological Investigations at the Mound Pond Site
}

\author{
Glenn T. Goode
}

As previously noted in Chapter 1, there are two artificially constructed earthen mounds known that are believed to be part of the Mound Pond site, the first mound (41HS12) standing along the eastern part of an alluvial terrace of Big Cypress Creek, and a second mound (41HS29) standing at the western end of the terrace. The first mound at the Mound Pond site, the main subject of this publication, is a flat-topped mound recorded by Davis as being ca. $100 \mathrm{ft}$. $(30 \mathrm{~m})$ in diameter and ca. 4-5 ft. $(1.85 \mathrm{~m})$ in height. There was an associated habitation area marked by an extensive midden deposit described by E. W. Hayner as more than $3 \mathrm{ft}$. in depth (December 26, 1960 letter from Hayner to E. Mott Davis, in Texas Archeological Research Laboratory files). As mentioned in Figure 5, one part of this habitation area was designated Area B in the 1977 excavations.

The second mound (41HS29) was a conical mound that measured 60-70 ft. in diameter and 9-10 ft. in height in the mid-1950s when Hayner excavated a $4 \times 7 \mathrm{ft}$. pit in the center of the mound to a depth of $6 \mathrm{ft}$. below the present ground surface. The mound fill was described by Hayner as being composed of sandy sediments. When E. Mott Davis examined the profile of the pit in October 1957, he described it as "light sand below (ca. $6 \mathrm{ft}$. deep) dark above. Some gray lenses. No sign of occupation" (notes on file at the Texas Archeological Research Laboratory, The University of Texas at Austin).

In March 1957, Mott Davis cut a 4 x $1 \mathrm{ft}$. profile in the top of the mound at the Mound Pond site (41HS12) that was excavated to a depth of $2.3 \mathrm{ft}$. (Figure 7). That profile encountered two red clay zones that may represent clay caps for structures, but the total depth of the mound profile was not exposed at that time. An engraved Caddo sherd was noted in the profile above the lower red clay zone. This profile is superseded by the profiles of the 1977 excavations that are described below.

\section{Excavation Strategies and Techniques}

The primary strategy of the Mound Pond excavations was to excavate two trenches that would intersect, or nearly so, near the center of the mound (Figure 8). These trenches would be excavated to submound levels, and, should time allow, the plan also included a block excavation in at least one quadrant of the mound. If sufficient manpower could be found, the plan was to excavate as much as one-half of one trench by hand, but without expecting to complete more than one-half of a full trench in this manner.

As it turned out, the western half (also called Trench 1) of the trench oriented east-west was excavated by hand to sub-mound levels, and the eastern half, also called Trench 2, was dug with a backhoe. In this report, the western half is designated the west trench, and the eastern half as the east trench. In the east trench, at the base of the mound and near the center of the mound, an undesignated test pit was dug $50 \mathrm{~cm}$ below the mound well into sterile sandy clay deposits. This was the last pit excavated at the site.

For the north-south trench, the north half (also called Trench 4) was excavated partly by hand and partly by backhoe, and it is designated as the north trench. This trench ran from near mound center to the northern edge of the mound. Because the block excavation was done in the southwest quadrant, a south trench was not dug. Instead, the east wall of the block served as a south trench profile, and the west wall also served as a south trench profile; a record of only this west wall profile has survived. 


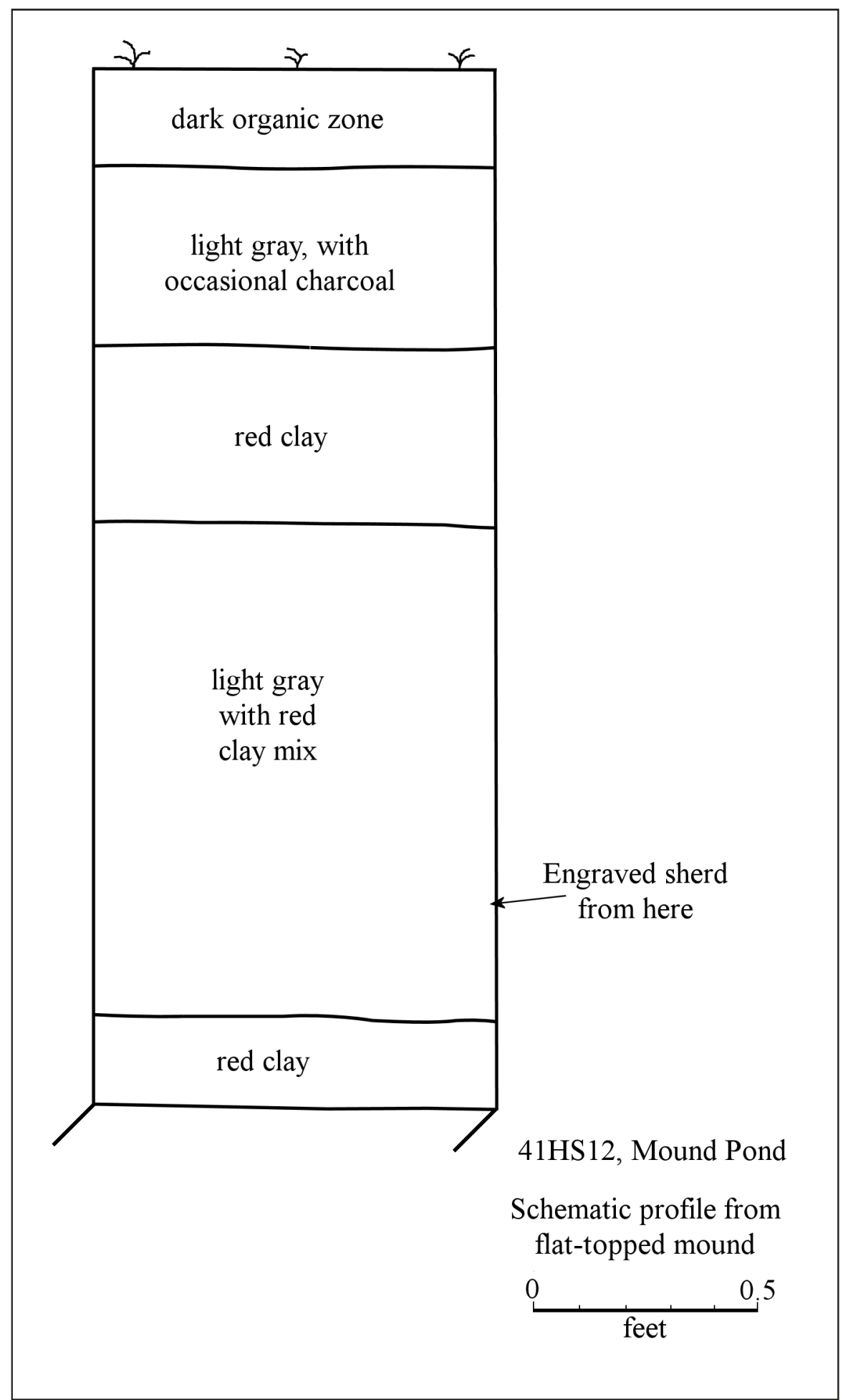

Figure 7. Schematic profile of the flat-topped mound at the Mound Pond site, redrawn from a profile described by Mott Davis in March 1957. 


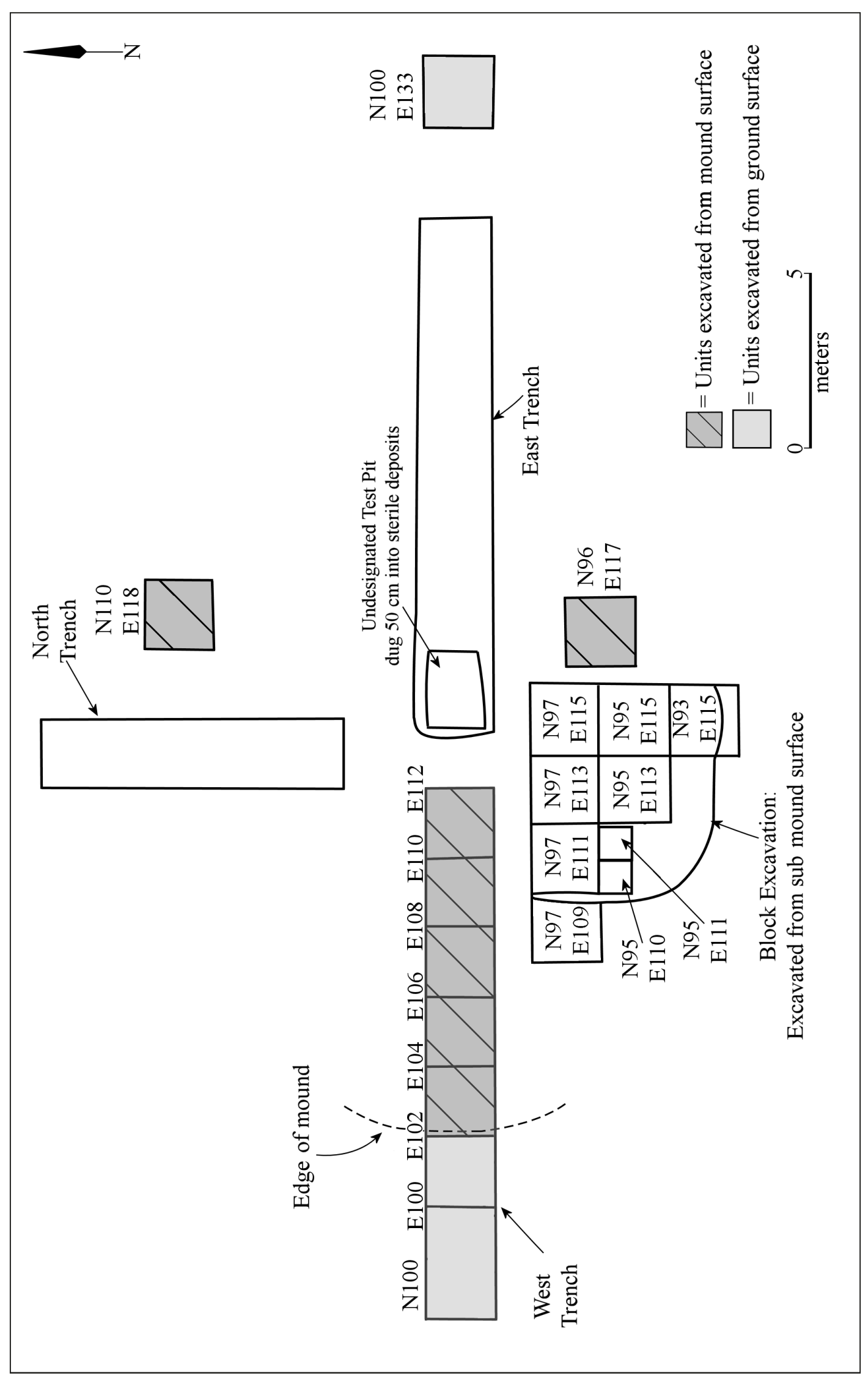

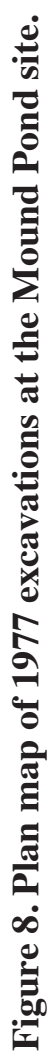


In the block excavation, the backhoe was used to remove mound fill down to within approximately $30 \mathrm{~cm}$ of a dense black midden deposit that had been discovered in the west trench, at the base of the mound. This midden deposit occurred only on the western side of mound center, and it was much denser along the south side of the trench; thus, the southwestern quadrant seemed the logical direction to explore the midden further with a block excavation.

The backhoe excavations were monitored closely for cultural materials and features, but no cultural features were observed, perhaps partly because we were not lucky enough to find a backhoe bucket without teeth. Structural features such as clay caps were highly visible and were shovel-shaved and/or troweled looking for cultural and structural clues.

Prior to commencing the excavation, readings for a contour map were taken with transit and stadia by Murphey and Goode, who were the only crew for a few days. To the west of the mound, readings were taken up to approximately $100 \mathrm{~m}$ from the mound vicinity, but not nearly that far to the east due to dense vegetation in places, and because a number of houses were in this area. To the north, Mound Pond was approximately $25 \mathrm{~m}$ from the mound, and a slightly greater distance was clear to the south before dense vegetation began. After the map readings had been completed, the transit was used to lay out a grid, with the primary line being the east-west axis; the north-south line was also staked at this time. The elevation datum was a large nail driven into a large tree just beyond the southwestern margin of the mound, and within a few meters of the paved road.

Following grid layout, hand excavation of the east-west trench was started from the west side of the mound, in a 2 x 3 m unit designated N100/E100 at the northeast corner. A backhoe was not yet available, so only the trench excavation by hand continued for several days. Depending on circumstances, the hand excavations were mostly done in 15 or $20 \mathrm{~cm}$ levels, with the matrix screened through 1/4-inch hardware cloth. Upon reaching the sub-mound midden and structure floor, smaller tools were used and levels were decreased to $10 \mathrm{~cm}$ in thickness.

The main purpose of the hand excavation was to detect clues of mound construction, and to find cultural features and artifacts that could be associated with particular episodes of construction and habitation. In this trench excavation, there were encountered in places lenses of orange clay that were presumed to represent episodes of clay capping. In some places the caps were fairly dense clay approximately $10 \mathrm{~cm}$ in thickness, while in others they were thinner and/or had sand interspersed in what seemed more like a zone of fill than an actual clay cap. These same attributes, or composition, of the clay caps and lenses were observed in all of the excavations, being for the most part in the upper half, or less, of the mound fill.

As briefly noted above, in the west trench, near the central portion of the mound, and immediately below the sandy fill of the first stage of mound building, there was encountered a dense midden deposit consisting of dark brown, gray, and black loamy and greasy matrix containing abundant artifacts and other habitation detritus. When this midden was found, excavation tools were changed to small tools such as trowels, which up to this point had been used mainly just to trowel floors and walls of units.

Likewise, when the sub-mound cultural deposit - the house floor and the midden - was encountered in the block excavation, the excavation from then on was almost entirely by trowel. Some of the $2 \times 2 \mathrm{~m}$ units of the block were excavated as $1 \times 2 \mathrm{~m}$ areas, and levels were reduced to $10 \mathrm{~cm}$ and sometimes 5 $\mathrm{cm}$ in thickness.

Other than artifacts, materials collected included charcoal and paleobotanical samples, large soil samples, and a pollen column of smaller soil samples. Among the final work was the drawing and photograph- 
ing of the wall profiles. At least one wall was recorded in each trench, and in other cases shorter or special sections of various walls were recorded. Inspiration was provided by Dr. E. Mott Davis, who was very much at home recording profiles, and by Dr. Clarence H. Webb, who was truly in his element excavating the midden, discussing mound building, and the relationship of Coles Creek and Caddo archaeology.

\section{Site Stratigraphy}

As noted previously, the earthen mound at the Mound Pond site was constructed at the margin of an alluvial terrace, very near to a meander lake called Mound Pond. In the mound vicinity most of the terrace is relatively flat, although there are widely scattered pimple mounds. The location at which the mound was eventually constructed was somewhat elevated above the general ground surface, however, possibly due to it being the location of one or more pimple mounds (Figure 9). In fact, in one of the missing profiles it appeared that two such small mounds or rises had been leveled by Caddo peoples preparatory to constructing the house at that location.

The best profile of site stratigraphy outside the mound is in Unit N98/E98, just beyond the western margin of the mound (see Figure 9). This profile is of the south wall (Figure 10): Zone 1: 0-18 cm, light gray fine loamy sand; Zone 2: 18-34 cm, light brown loamy to clayey sand with abundant reddish-brown mottles; Zone 3: $34-54 \mathrm{~cm}$, pale brown clayey sand with abundant reddish-brown mottles; and Zone 4: $54-58 \mathrm{~cm}$, brown sandy clay with darker brown and olive mottles. Essentially this same profile occurred in the test pit dug in Area B, approximately 50 m southwest of the mound area.

\section{Mound Stratigraphy}

The first occupation of the site where the mound was eventually built included a structure erected on a sandy surface. The ground surface here appears to have been somewhat higher than the surrounding terrace, possibly due to the presence of one or two pimple mounds; this surface appears to have been leveled prior to construction. At the time of excavation, the sub-mound deposit in the west trench (see Figure 10) consisted of approximately $10 \mathrm{~cm}$ of loamy sand overlying a heavily mottled brown deposit that ranged from clayey sand to sandy clay. The sub-mound occupation surface was readily identifiable in most profiles, particularly in places where evidence of burning was well preserved.

\section{First Stage of Mound Building}

Following the occupation of the pre-mound surface, a structure built there was burned and then at some point was covered with a small mound apparently composed entirely of sand. The first sand put down was a darker brown color due to the presence of organic material and this deposit appears to have been mounded up in places as much as $70 \mathrm{~cm}$ near the center of the mound, with much less of it used farther away. The underlying deposit was rich in clay and therefore is not the source of this darker sand. Next, the light to pale brown sand from a different deposit was added (Figure 11; see also Figure 9) to complete the covering of the burned structure.

Nothing was found that would suggest a significant amount of time elapsed between the burning and the covering of the structure. Judging only by the extent of this sandy deposit to N100/E106 in the west trench (see Figure 9), it is estimated that this covering, or mound, of sand was approximately $16-18 \mathrm{~m}$ in diameter, and its height was very close to $1.0 \mathrm{~m}$.

This small sandy mound, then, is the first stage of mound building, and it appears to have been abandoned after construction, or at least was not added to for some time, because the mound's surface 

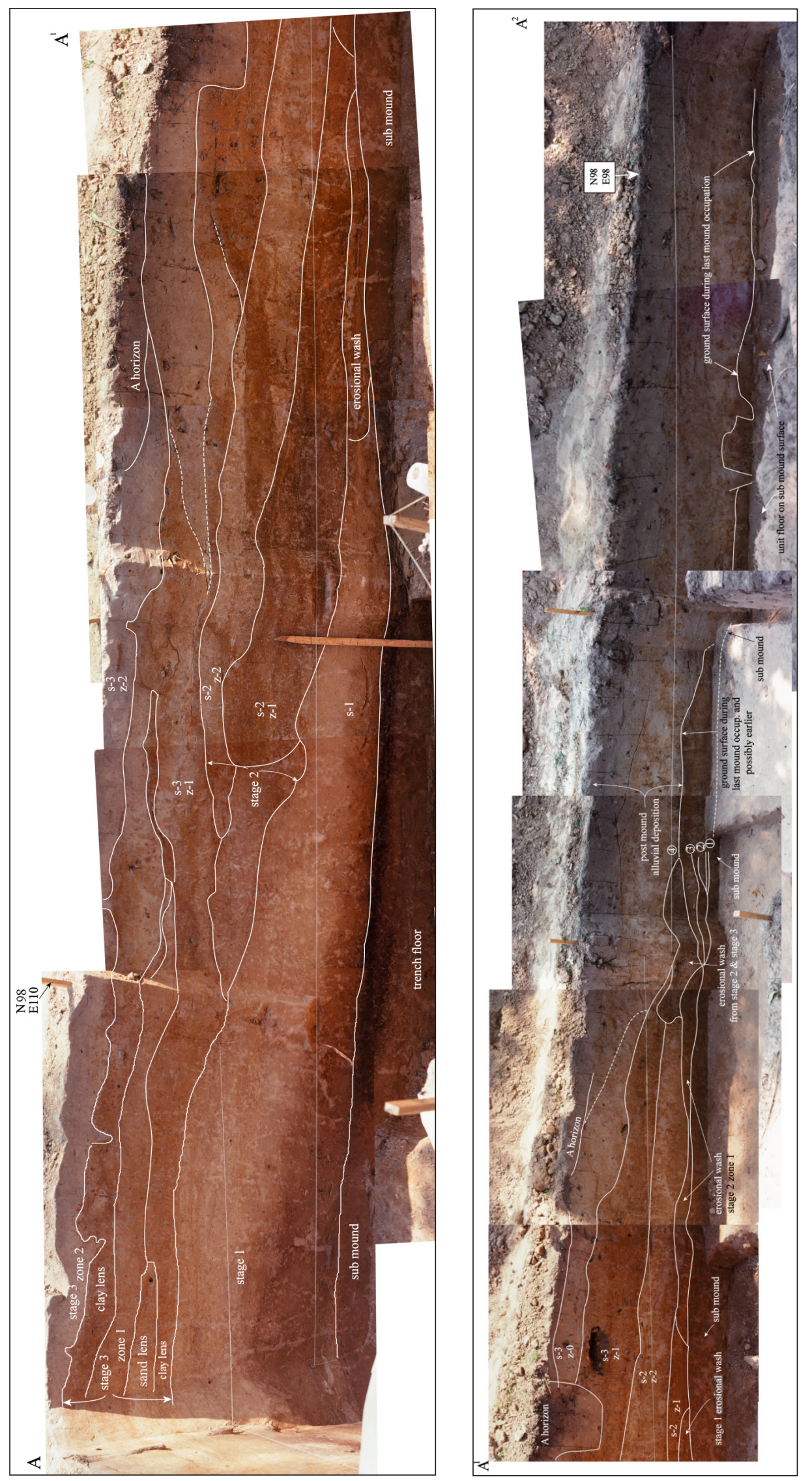

 


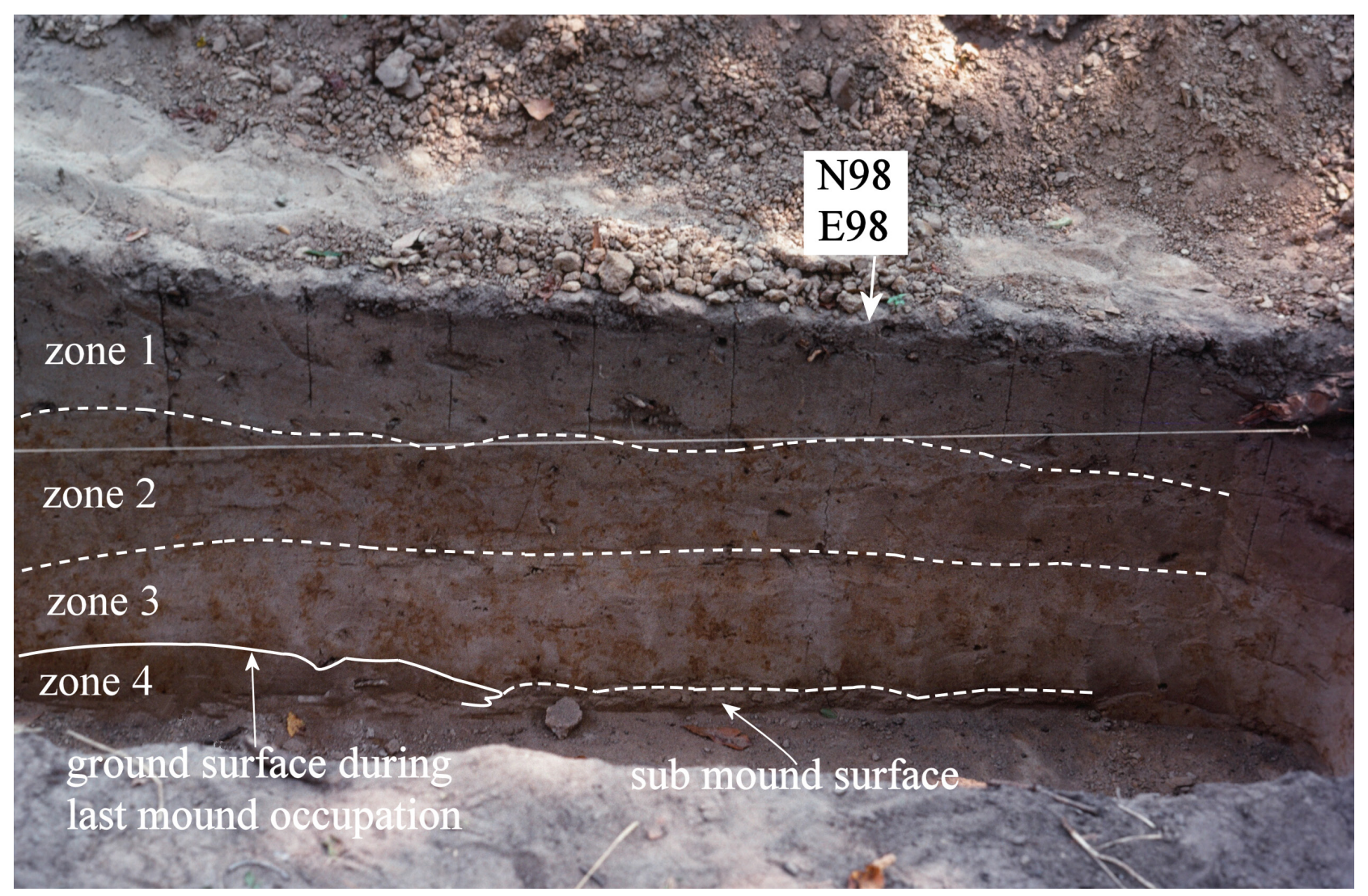

Figure 10. Representative site profile in West Trench, Unit N98/E98, south wall.

has erosional damage. The sandy matrix from multiple erosional episodes then accumulated along the mound's margins in extremely thin lenses. These erosional deposits can be clearly seen in the west trench (see Figure 9), and in the west wall of the Block Excavation (Figure 12; see also Figure 11).

A closer view of the erosional deposits overlying the black midden deposit is provided in Figure 13. It appears that there are two main zones of erosional deposition, the deeper one associated with Stage 1 of the mound, and the upper one probably also associated with Stage 1, although there may be some Stage 2 admixture. Most Stage 2 erosional deposits should be farther to the south where the Stage 2 margin was.

These erosional deposits occur in the west wall profile of the block excavation, the wall also being the western edge of Unit N97/E111. This is a $2 \times 2$ m unit and most of its floor is in this view shown in Figure 13. The floor of the unit is the base of the midden deposit, which gradually slopes downward to the west and northwest.

There is another feature of mound construction that should be mentioned, although there is only one available oblique and indistinct view of it from a distance (Figure 14). In the East Trench, approximately 8-10 m east of the center of the mound, a berm of whitish-gray sand occurred in both the south and north walls; and in both walls of the North Trench, and at a similar distance from the mound center. Thus, the berm was semi-circular and flanked perhaps as much as (or more than) the eastern half of the mound. It is believed, although without absolute certainty, that this berm was also constructed on the sub-mound surface; it was approximately $2.5 \mathrm{~m}$ in width and $85 \mathrm{~cm}$ in height, with a rounded top. The berm did not occur in the west trench or the block excavation. 

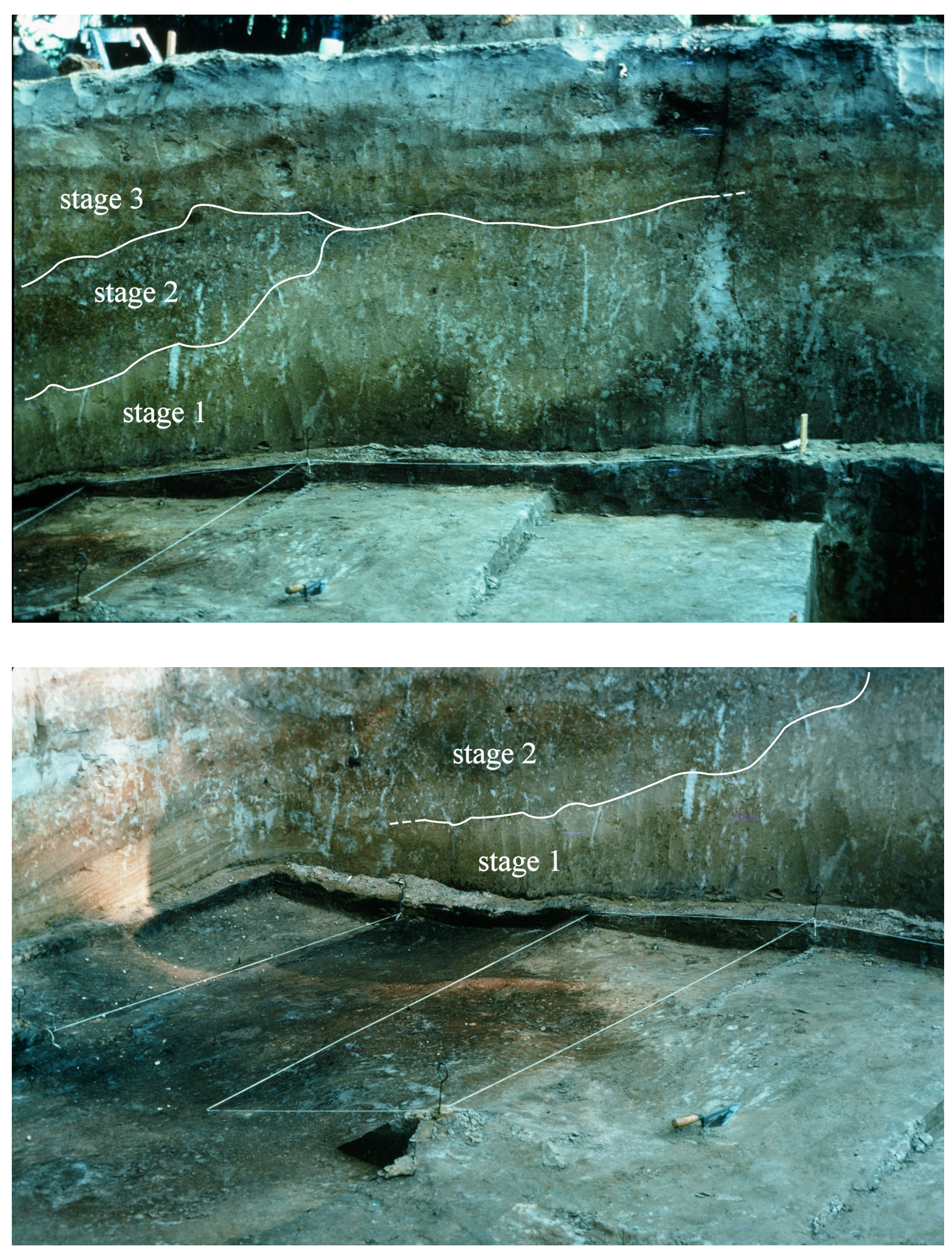

Figure 11. Block excavation, north wall profile. 


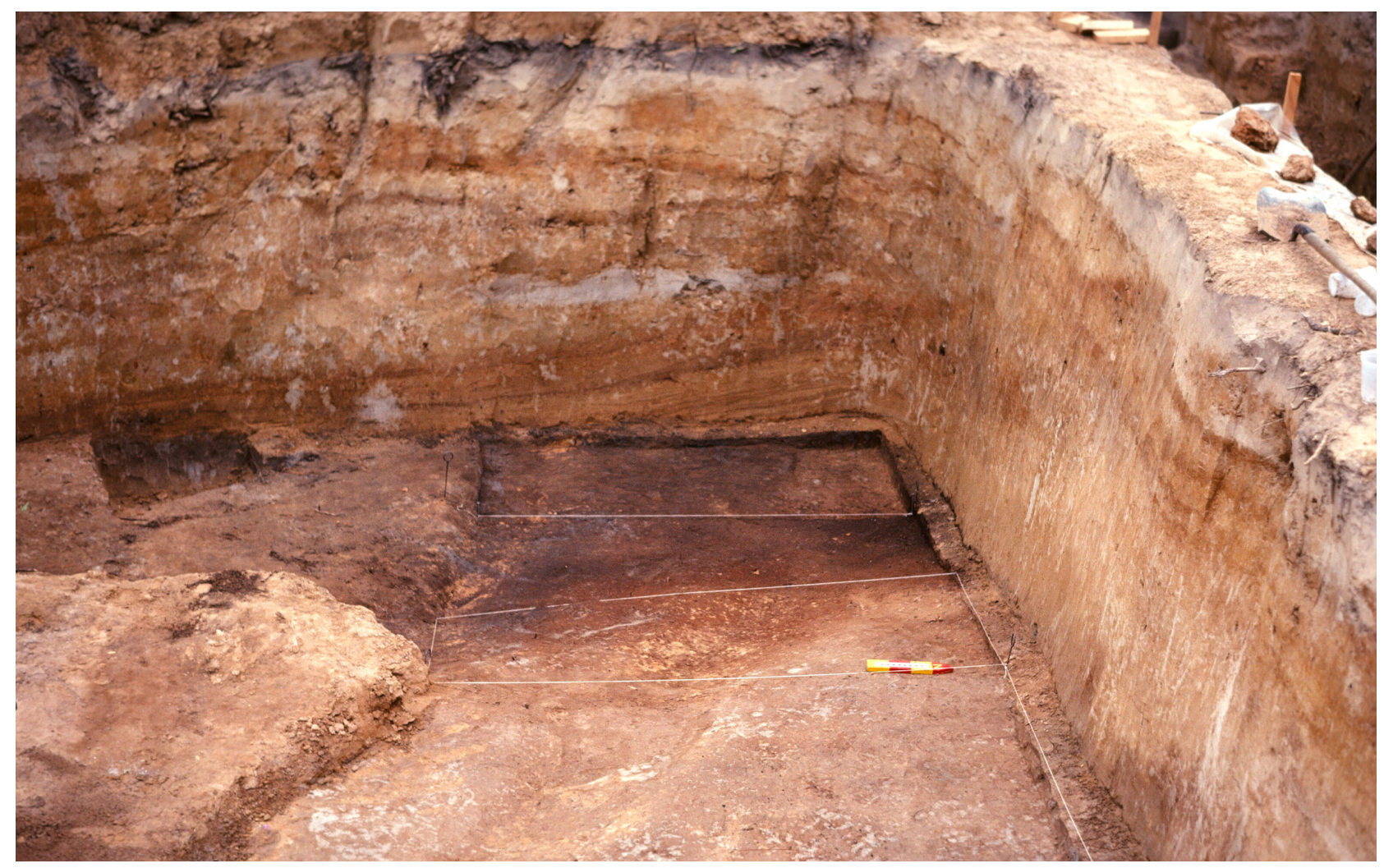

Figure 12. View west of the block excavation, north and west wall profiles; balk separating Block and West trench.

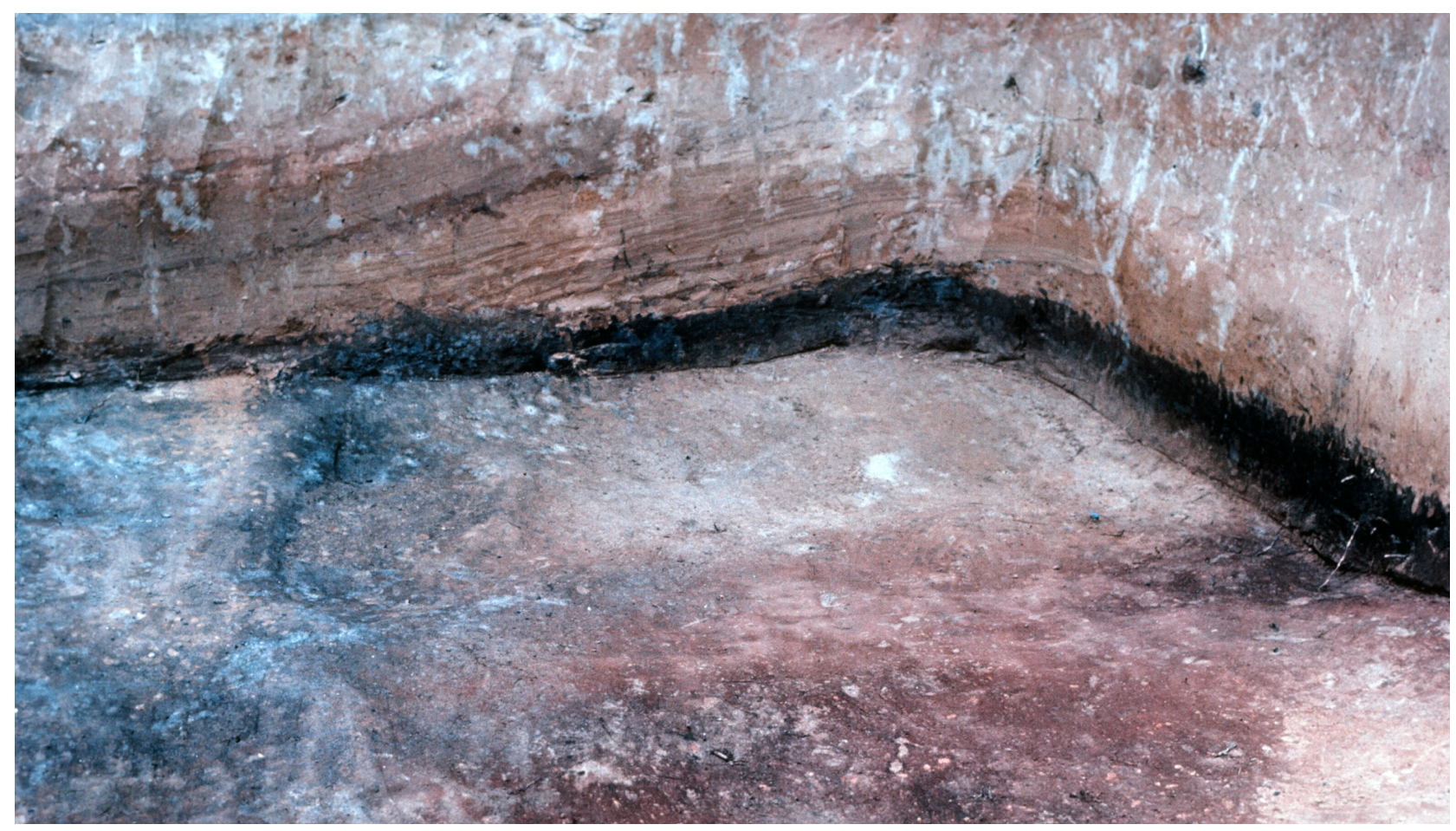

Figure 13. West by northwest view of the block excavation, with midden deposit and overlying erosional deposits in north and west walls. The floor is mainly of $2 \times 2 \mathrm{~m}$ Unit N97/E111, and is at the base of midden deposit. 


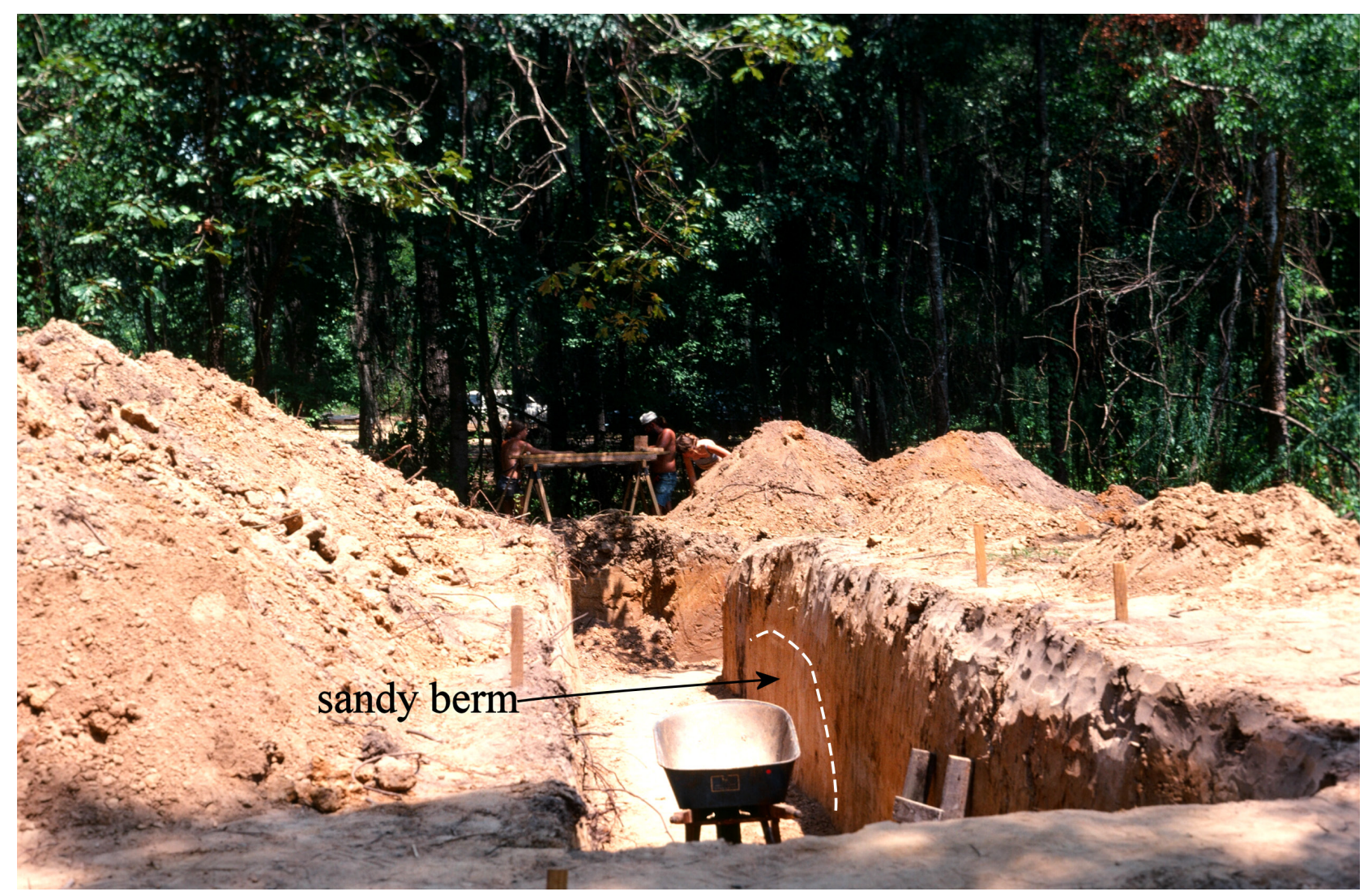

Figure 14. South wall of East trench, with east view of light-colored sandy berm partially obscured by wheelbarrow.

\section{Second Stage of Mound Building}

After a perhaps substantial period of time, Caddo peoples returned and enlarged the mound, although these inhabitants did not make the kinds of ceramics that were prevalent in the sub-mound occupation (see below). This was the second stage of mound building, and it appears that only the margins were added to while the central portion was left as it was. The second stage addition is seen in the south wall of the west trench (see Figure 9) and in the north wall of the Block Excavation (see Figure 11), as well as in the west wall of the Block Excavation (see Figure 12).

In Figure 8, the zones labeled Stage 2, Zones 1 and 2, are believed to represent the Stage 2 addition. Zone 1 was mostly orange clay, and after it was laid down there was another episode of erosion, although seemingly much less substantial than the erosion from Stage 1. Zone 2, mostly sand, was then applied to bring more of the mound up to the height of Stage 1. The Stage 2 mound likely then served as a platform for the first structure on the mound, partly because there was a posthole from this surface in the south wall of the east trench. From this Stage 2, Zone 2 surface there is also a deposit of erosional wash documented in the west trench profile (see Figure 9). Therefore, there appears to have been another hiatus in occupation following Stage 2, but again, there is only a fraction of the erosional deposit associated with Stage 1. Erosional deposits from Stage 2 probably also exist in the west wall of Figure 12, but the origin of some of these deposits is less clear here. 
The photographic documentation of these trenches is the only surviving record of the mound building sequence, and it is only in the West Trench that the mound's margin is seen. Stage 2 expanded the diameter of the mound, to the west, by approximately $8 \mathrm{~m}$. Given the symmetry of the mound it is reasonable to estimate that it was expanded by roughly equal amounts in all directions.

\section{Third Stage of Mound Building}

The third stage of mound building appears to be the most complex, as it encompasses several alternating lenses of clay and sand, and lenses composed of both. Technically speaking, Stage 3 should perhaps be regarded as a number of stages - perhaps four-but each profile is different, and some lenses are so thin and/or discontinuous as to make precise delineation and identification (as a clay cap, or not) virtually impossible. In any event, the series of additions called Stage 3 stands out from the previous two mound building stages.

Without knowing how much time elapsed between Stage 2 and Stage 3, or the significance of the hiatus or of the subsequent addition itself, it is clear that the first Stage 3 addition was a lens, or cap, of sandy orange clay. In the west trench (see Figure 9), this first cap is best seen in the south wall of Unit N100/ E112 (beginning at left margin) as being an approximately $10 \mathrm{~cm}$ thick deposit but thickening to about 20 $\mathrm{cm}$ near Unit N100/E110. The uppermost cap is also clearly visible, but in between the two there appears to be a third, very thin, lens that is separated by sand, but then is just barely above the first lens, and finally appears to merge with it. In the Block Excavation north wall profile (see Figure 11), there appear to be four clay lenses of varying thickness, and which, although generally lying flat, are either discontinuous or irregular in places. Moving, then, from mound center toward the west, the clay lenses become impossible to follow, but are then somewhat better defined in the west wall of the Block Excavation (see Figure 12). The underlying Stage 2 deposit is also substantial in this profile, and the sub-mound midden and the overlying erosional surfaces from Stage 1 (and possibly Stage 2) are clearly visible.

Stage 3, then, appears to comprise at least four lenses of clay, between alternating lenses of sand, with the uppermost sandy layer being the fourth one. If each clay lens represents a typical clay cap applied after a structure had been removed, then several structures may be represented in Stage 3. If this is in fact the case, then each pair of clay and sand lenses has a total thickness of only about $20 \mathrm{~cm}$. Also not clear is when the alternating sand lenses were applied, but it would have been prior to construction of a new building. One thing that is obvious is that a sand lens was applied prior to the last occupation, but a clay cap was not applied after that occupation (Figure 15). Another thing that was obvious is that none of the structures of Stage 3 were burned. The total thickness of the Stage 3 deposit is approximately $85 \mathrm{~cm}$.

Evidence of at least a second structure on the mound, this time in Stage 3, occurred in the south wall profile (which is missing) of the East Trench. There, approximately 3-4 m east of the mound center, was another posthole that has been interpreted to be associated with the last structure on the mound.

In the west trench profile (see Figure 9), at the mound's western margin, there is an erosional accumulation that is at least partly from Stage 2, but probably also partly from Stage 3. However, compared to the erosional deposits from Stage 1 and Stage 2, this deposit seems like a very small amount for a mound standing for a lengthy period of time. Beyond the mound's western margin, sloping down to the west, there is a relict ground surface - now covered with alluvial deposits - that was the ground surface during and after the Stage 3 occupations. This surface does not retain any erosional deposits. Due to the fairly steep drop-off here, perhaps erosional deposits washed farther down slope. It is also significant to note that below this relict surface there are at least three earlier ones that are related to the earlier occupations 


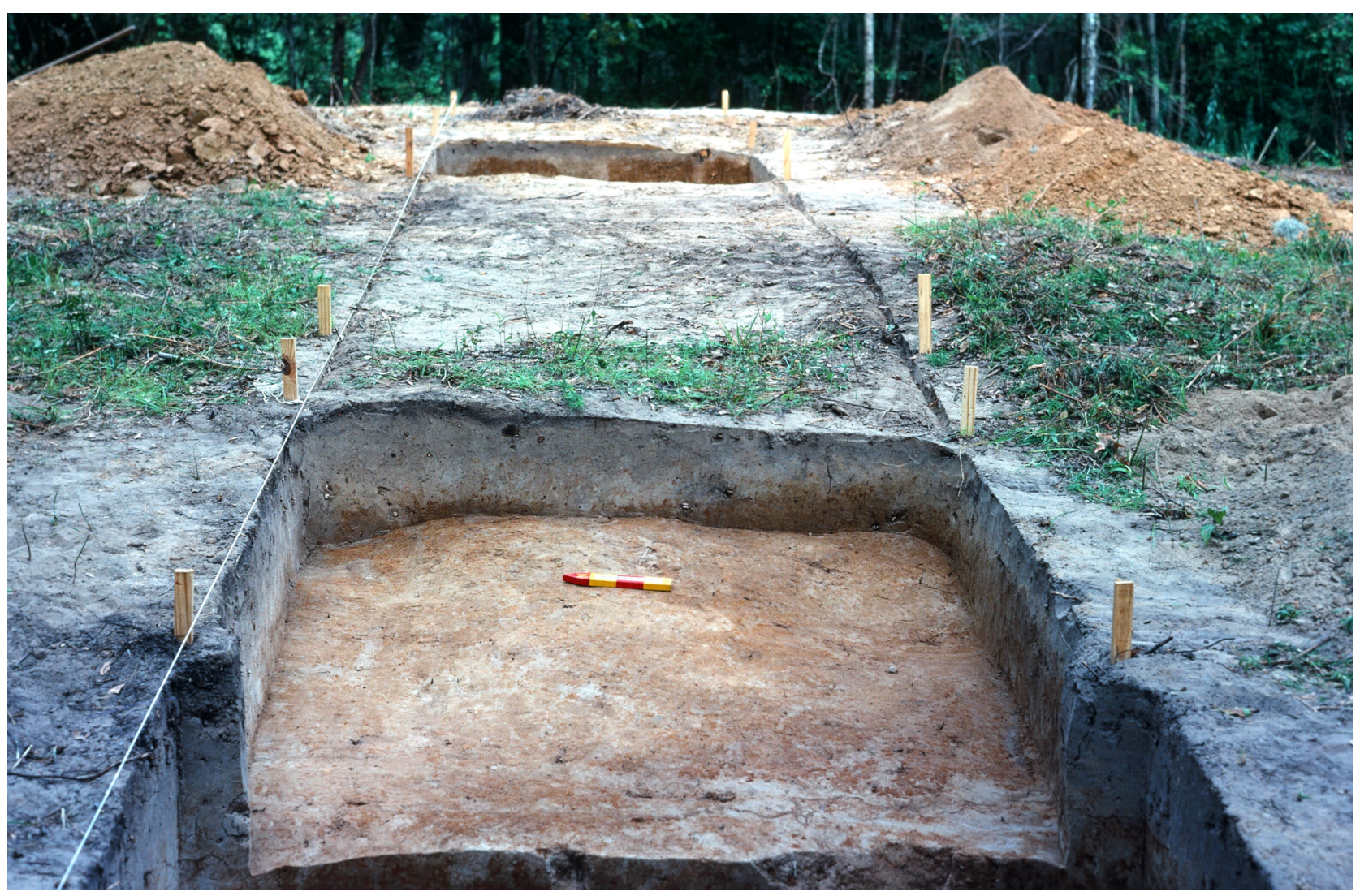

Figure 15. View east of the last clay cap and overlying sand cap.

of the site. Each surface was preserved by alluvial deposition (with perhaps some colluvial run-off from the mound), with deposition of perhaps $60 \mathrm{~cm}$ following the last habitation.

In the West Trench profile (see Figure 9) it appears that the Stage 3 additions did not increase the mound's diameter at all in this direction. Stage 3, then, was devoted only to making a higher platform for the structures.

\section{Summary of Mound Construction Sequence}

\section{Stage 1}

After a house was built and occupied on the original ground surface, it was burned and covered with a mound of sand. Some of the first sandy deposits laid down were small mounds of darker brown matrix that apparently contained significant amounts of decomposed organic material. Then, a lighter-colored sand was used to complete the process. The maximum height of this Stage 1 deposit is approximately 1.0 $\mathrm{m}$, and the projected diameter is $16-18 \mathrm{~m}$.

\section{Erosional Interval 1}

After the first stage of mound construction was completed, there apparently was a hiatus in use of this portion of the site. The evidence of this hiatus comes in two forms, both being the result of erosion. The 
mound's surface was misshapen by erosion and the eroded sandy sediment built-up in thin lamina that appear as extensions of the Stage 1 deposit.

\section{Stage 2, Zone 1}

When work resumed on the construction of the mound, it did not raise the height at the center of the mound, but consisted of expanding the diameter and bringing a portion of the mound up to the original maximum height of Stage 1. A layer of orange clay was added, tying onto Stage 1 in the vicinity of N100/ E110 (see Figure 9).

\section{Erosional Interval 2}

Following the addition of Stage 2, Zone 1, there was an interval of erosion that was much less substantial than the erosion from the Stage 1 mound.

\section{Stage 2, Zone 2}

This sandy cap completed the Stage 2 addition, and a posthole in the (missing) East Trench profile indicates that a structure was built upon the expanded surface of Stage 1, at that time a combination of Stages 1 and 2. This was the first structure built on the mound.

\section{Erosional Interval 3}

This erosional interval consisted of sandy deposits washed from the Stage 2, Zone 2 surface and collected along the mound's western margin.

\section{Stage 3}

The first addition to the mound in Stage 3 was a clay cap $10+\mathrm{cm}$ in thickness. It was then overlain by a sandy cap of similar thickness, and the two are interpreted as being a set, the sandy lens seemingly having been applied before a structure was erected. Apparently, this same scenario was repeated at least three more times, although it is not known how many or what kind of structures were built in Stage 3. Also, there were no clues regarding depositional or temporal intervals between the various sets, or sub-stages. This is because the only surviving profile depicting the margin of Stage 3 is the West Trench (see Figure 9), and the various sets of clay/sand are not distinct here. There were no indications that any structures on the mound were burned.

\section{Erosional Interval 4: abandonment of the mound}

At the western margin of the mound (see Figure 9), there was some erosion from Stage 3, but this cannot be tied to any particular habitation of the site during the perhaps lengthy duration of the Stage 3 occupation. If there was much erosion following the last habitation, these deposits apparently accumulated down-slope beyond the excavations. Following the last occupation, approximately $60 \mathrm{~cm}$ of alluvial deposit accumulated on the mound's western flank. 


\section{Features}

The few features found in the test excavation include a hearth, three post holes, and a midden deposit. Other anomalous soil changes were mostly observed in wall profiles, but there was insufficient time to investigate them. This was also the case regarding certain unexplained aspects of mound construction.

Feature 1 was a small hearth in Unit N110/E118, at the contact of the uppermost sandy deposit and the underlying clay cap, at a depth of approximately $15-20 \mathrm{~cm}$. Sub-round in shape and $50-60 \mathrm{~cm}$ in diameter, the hearth consisted of thoroughly burnt and fractured flint pebble fragments, which occurred as small clusters and scattered fragments rather than a continuous layer of rock. The clay base was burnt and discolored and lumps of burnt clay were present, as were scattered, small flecks of charcoal.

Feature 2 was a post hole that was exposed on the sub-mound house floor (Figure 16) in Unit N95/ E115. It was approximately $35 \mathrm{~cm}$ in diameter and $40+\mathrm{cm}$ in depth. The upper $20-25 \mathrm{~cm}$ of fill were light yellowish-brown loamy sand, and the deeper portion contained mixed brown, reddish-brown, and charcoal-stained loamy sand, along with sufficient charcoal for a radiocarbon sample. Nearby, other much smaller areas of the light yellowish-brown matrix were irregularly shaped and only $2-3 \mathrm{~cm}$ thick.

Feature 3 was a midden deposit that may have accumulated mostly or entirely outside the sub-mound structure. In the north wall profile of the block excavation (Figure 17), near grid point N97/E111, the submound surface begins to gradually slope downward to the west, but the midden starts approximately 50

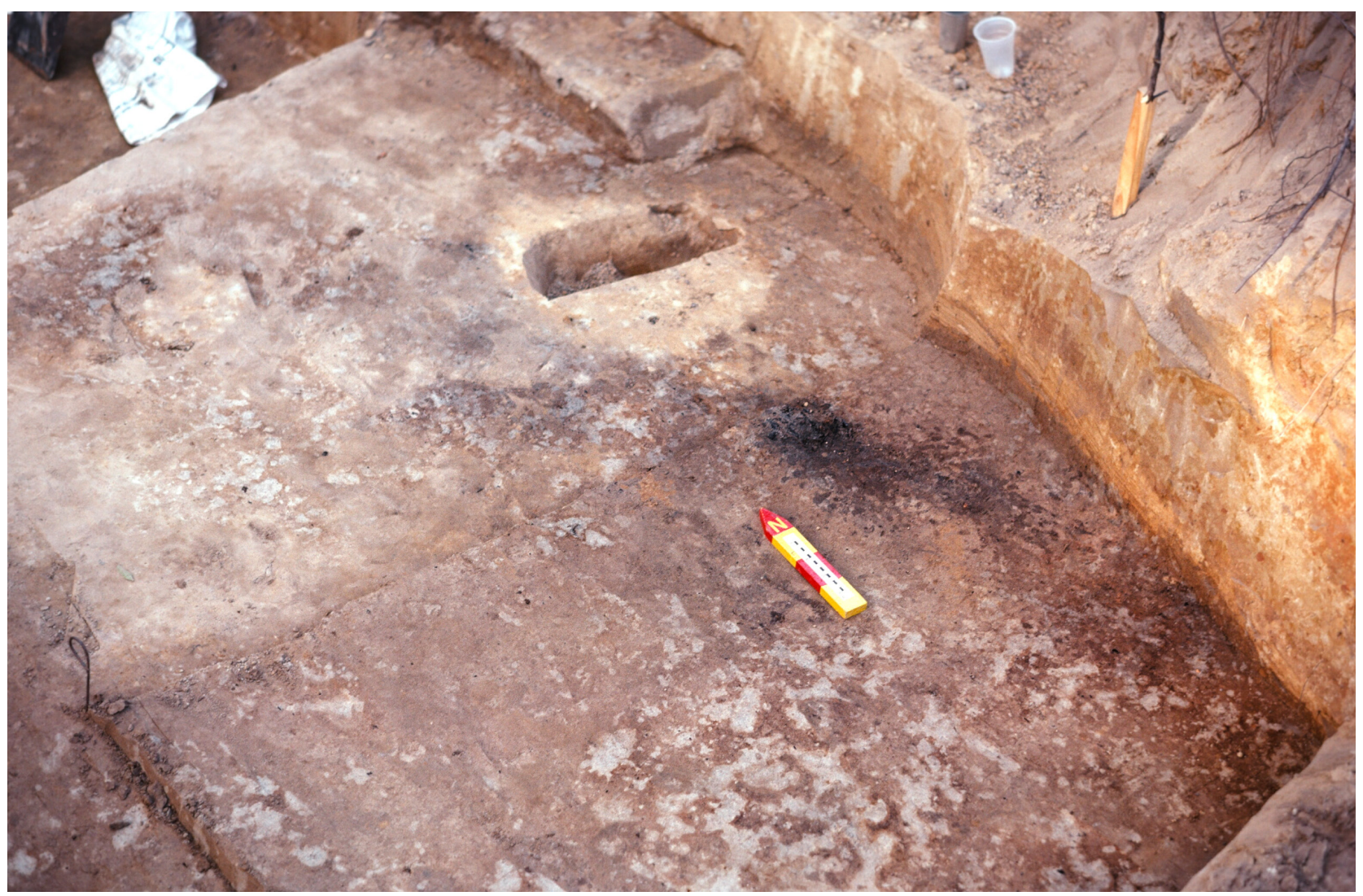

Figure 16. View to the northeast of Unit N95/E115, and a posthole and thermally discolored floor of the sub-mound structure. 


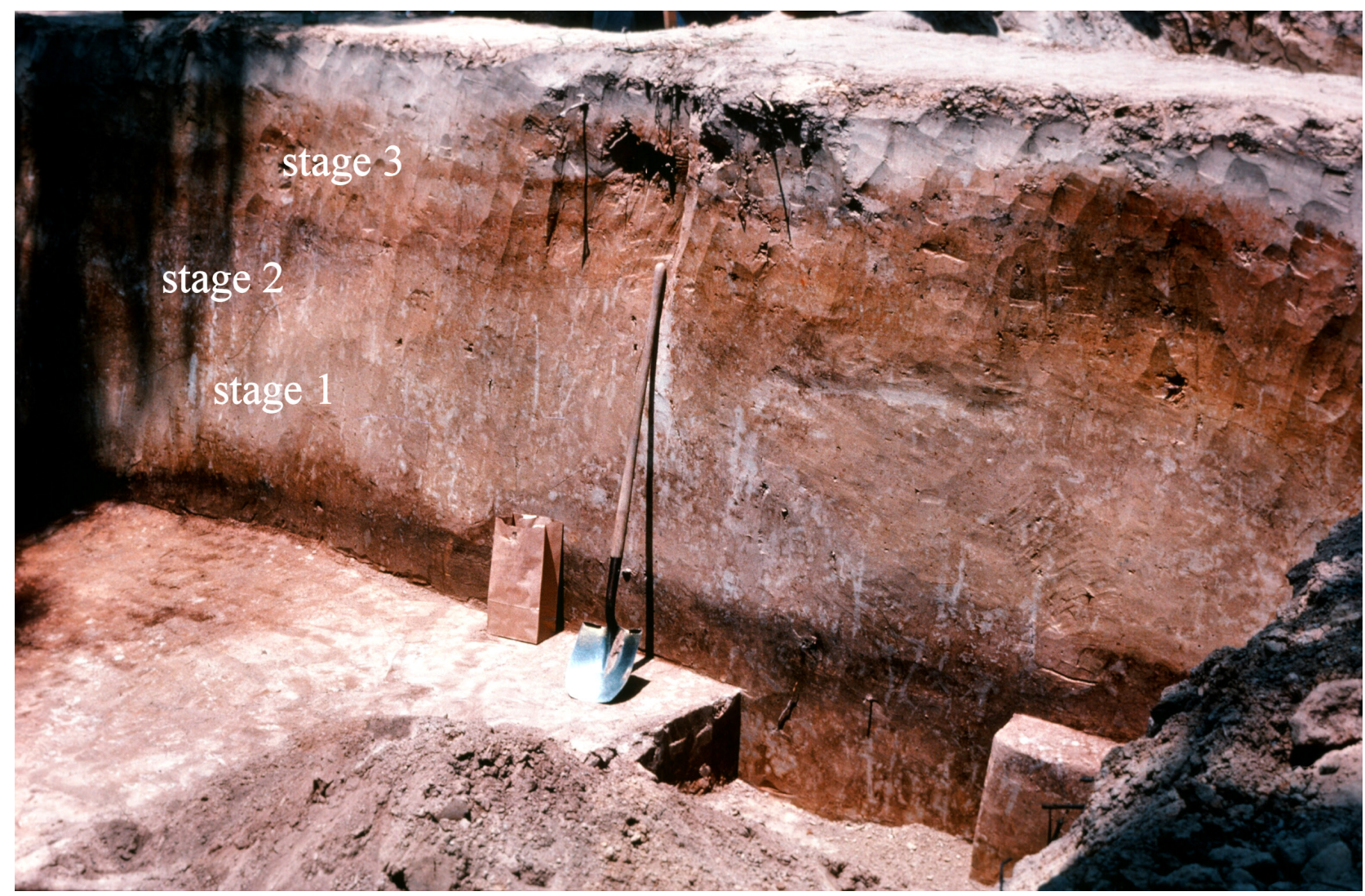

Figure 17. View to the north of the north wall and floor of block excavation after removal of the midden and the structure floor. This is a work shot without a scale, but the length of the shovel is $140 \mathrm{~cm}$.

$\mathrm{cm}$ east of that point on level ground: the edge of the structure was not detected. In any case, the densest portion of the midden was in Unit N97/E111, and both its base and surface sloped downward to the west, and then extended into and beyond the unit's west wall (see Figure 13).

Ranging from 6-12 cm in thickness, the midden was composed of dark brown, dark gray, and black loamy sand, so heavily enriched by organic material that it had a moist clayey texture and a greasy feel. It contained a large quantity of artifacts (especially Coles Creek style horizontal incised ceramics), plant and animal remains, burnt clay, and charcoal. 



\section{Chapter 3, Radiocarbon Dating}

\section{Timothy K. Perttula}

Two radiocarbon dates had been previously obtained from samples gathered during the 1977 excavations in the mound and sub-mound midden deposits at the Mound Pond site. The samples were selected by Glenn T. Goode and delivered to Dr. Darrell G. Creel at the Texas Archeological Research Laboratory at The University of Texas at Austin (Darrell G. Creel, 2011 personal communication):

- CAMS 396, charred nut, conventional age of $900 \pm 140$ B.P., from N100/E110, Level 10 (99.6099.50 m elevation), collected 7/16/1977. Level 10 (>170 cm bs) marks the sub-mound midden deposits in this unit. Using IntCal09 (Reimer et al. 2009), the 1 sigma calibration age range is 682-935 B. P. or A.D. 1015-1268. At 2 sigma, the calibrated age range is 639-1070 B.P. or A.D. 880-1311.

- CAMS 397, charred wood, conventional age of $970 \pm 120$ B.P., from Feature 2 (charred wood in post hole from the sub-mound floor), 99.80-99.70 m elevation, collected 7/23/1977. At one sigma, the calibrated age range is 739-975 B.P. or A.D. 975-1211. The 2 sigma calibrated age range is $673-1148$ B.P. or A.D. 802-1277.

Because of the large standard deviations on both AMS samples, these dates from the mound deposits are not considered to be particularly useful in establishing the age of mound construction with any certitude. At one sigma (67 percent probability), the mean calibrated age range of the two dates is A.D. 995-1240, falling squarely in the Early Caddo period (ca. A.D. 1000-1200). The two sigma (95 percent probability) mean calibrated age range is substantially larger, A.D. 841-1294, perhaps suggesting that the initial archaeological deposits at the site began to accumulate in the Formative Caddo period (ca. A.D. 800-1000), but continued to accumulate into the Middle Caddo period (ca. A.D. 1200-1450); it is not certain where the samples actually date within the calibrated age ranges. Based on the kinds of decorated sherds found in both the mound and the sub-mound midden, the latest calibrated ages of the two dates seem implausible.

Two additional radiocarbon samples were submitted to Beta Analytic, Inc. from the Mound Pond site in 2011, after the paleobotanical materials had been analyzed and separated into wood charcoal, nut meat, and nutshells (see Bush, below). These two samples came from the sub-mound midden deposits, with the purpose being to precisely establish their age, because the first two radiocarbon dates did not accomplish that due to their wide standard deviations:

- $\quad$ N100 E 100, midden, ca. $175 \mathrm{~cm}$ bs, charred Carya sp. nutshell (1.03 g), and

- $\quad \mathrm{N} 100 \mathrm{E} 108$, midden surface to $5 \mathrm{~cm}$ below the midden surface, charred Carya sp. nutshell (0.32 g)

The results of the latest radiocarbon dating analysis are provided in Table 2 (see also Appendix 2). The 2 sigma calibrated age ranges for the two samples of charred Carya sp. nutshells from sub-mound midden deposits range from A.D. 1030-1220, with calibrated intercepts at A.D. 1050, A.D. 1090, A.D. 1130, A.D. 1140, and A.D. 1170. These calibrated age ranges fall squarely in the Early Caddo period (ca. A.D. 1000-1200). 
Table 2. Radiocarbon Dates obtained from Beta Analytic from the Mound Pond site.

\begin{tabular}{lllllll}
\hline Provenience & $\begin{array}{l}\text { Lab No. } \\
\text { age (B.P.) }\end{array}$ & $\begin{array}{l}\text { Measured } \\
\text { age (B.P.) }\end{array}$ & $\begin{array}{l}\text { Conventional } \\
\text { cal (A.D.) }\end{array}$ & $\begin{array}{l}\text { 1 sigma } \\
\text { cal (A.D.) }\end{array}$ & $\begin{array}{l}\text { 2 sigma } \\
\text { cal A.D. }\end{array}$ & Intercept \\
\hline $\begin{array}{l}\text { N100 E100, } \\
\text { midden, 175 }\end{array}$ & B-303736 & $870 \pm 30$ & $880 \pm 30$ & $1160-1210$ & $1040-1100$, & 1170 \\
cm bs & & & & & $1120-1220$ & \\
$\begin{array}{l}\text { N100 E108, } \\
\text { midden } \\
\text { surface to }\end{array}$ & B-303737 & $890 \pm 30$ & $930 \pm 30$ & $1040-1160$ & $1030-1170$ & 1050, \\
$\begin{array}{l}5 \text { cm bs } \\
\text { midden } \\
\text { surface }\end{array}$ & & & & & 1090, \\
\hline
\end{tabular}

The mean of the conventional ages for all four radiocarbon samples from the Mound Pond site is $920 \pm 35$ B.P. (A.D. $1030 \pm 35$ ). Using the IntCal09 calibration (Reimer et al. 2009), the 1 sigma age range of the averaged dates is A.D. 1037-1163, while the 2 sigma age range of these dates is A.D. 1024-1212.

OxCal v4.1.7 calibrations provide slightly different age ranges at 2 sigma (95.4 percent probability) for the two most recent Mound Pond dates, with age ranges that extend from A.D. 1025-1221 (Figure 18a-b). The principal peaks in probability for both calibrated dates range from A.D. 1025-1169 (Figure 18b) and A.D. 1150-1220 (Figure 18a). 

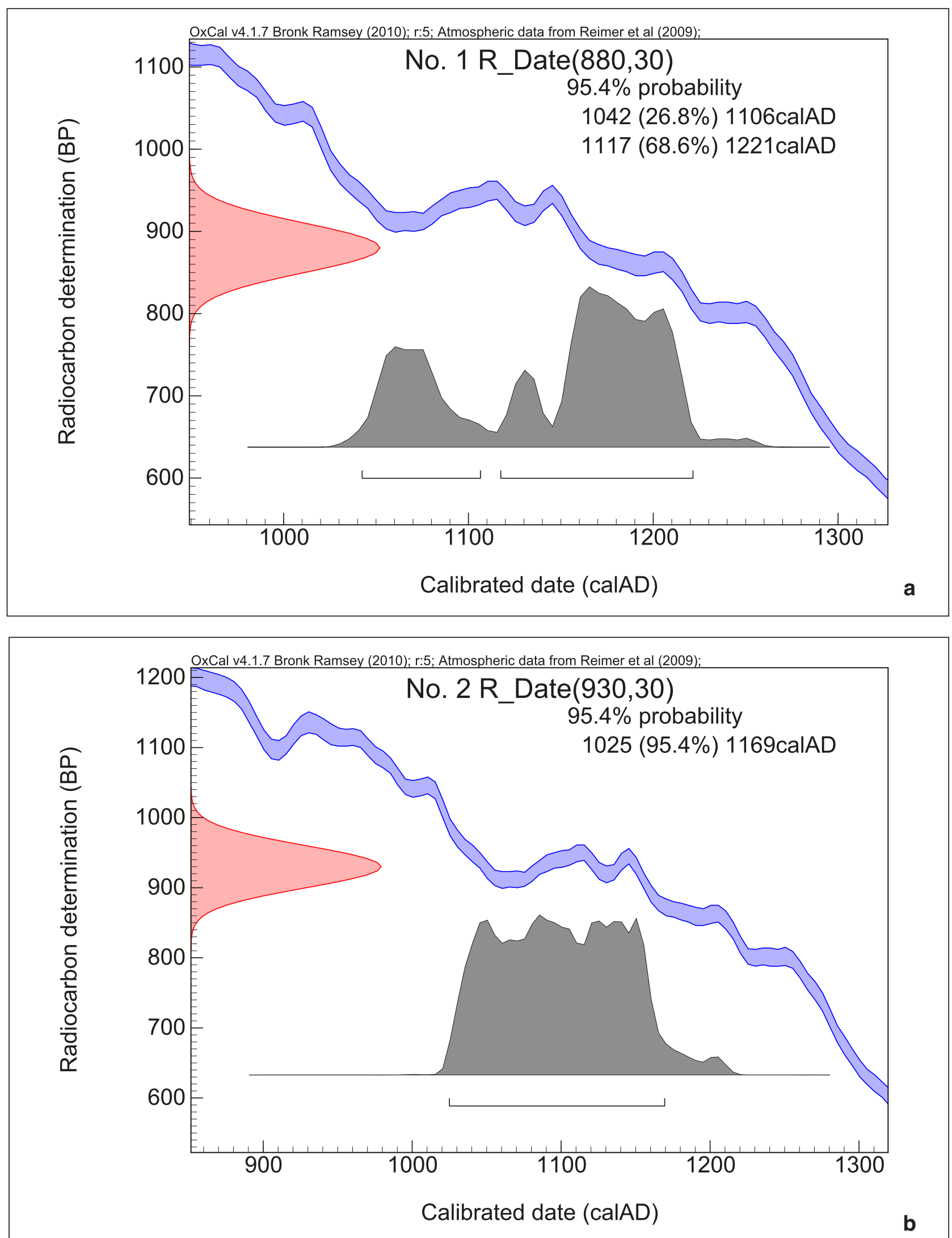

b

Figure 18. OxCal calibrations for Beta-303736 and Beta-303737 in sub-mound midden deposits at the Mound Pond site: a, Beta-303736; b, Beta-303737. Figure courtesy of Robert Z. Selden, Jr. 



\title{
Chapter 4, Analysis of the Lithic Artifacts from the Mound Pond Site
}

\author{
Glenn T. Goode
}

The lithic artifacts recovered from the excavations at the Mound Pond site amount to approximately 1500 specimens. As is often the case in lithic assemblages in this part of East Texas (Webb et al. 1969; Young 1981; Brewington et al. 1995), the great majority of these artifacts are pieces of flake and core debitage from the manufacture of chipped stone tools, a sample of approximately 1400 specimens. The sample of lithic tools is approximately 7 percent of the total assemblage.

For the following analysis, a much smaller portion of the lithic assemblage, both debitage and tools, is available because most of the recovered artifacts can no longer be found and their whereabouts are unknown. Thus, the analyzed debitage sample $(n=644)$ consists of 522 flakes and fragments, 105 reduced cores, and 17 tested pebbles. The analyzed tools consist of a single diagnostic formal tool (an arrow point), non-diagnostic shaped specimens, flake tools modified by minor shaping and/or use, and tool blanks or preforms broken during manufacture or otherwise discarded. However, the specimen inventory on file at TARL at least provides basic information on the missing artifacts, such as type designations of certain arrow points.

Other recovered lithic materials include 248 fragments of burned and fractured flint, approximately 100 small to very small unmodified siliceous pebbles, and numerous, mostly small, pieces of ferruginous sandstone. None of these materials are considered to be artifacts although all were brought to the site by its inhabitants.

\section{Notable Attributes of the Mound Pond Lithic Assemblage}

The most notable features of the Mound Pond lithic assemblage are: (1) a great majority of the specimens are made of lithic materials that were locally and regionally available; (2) the average size of the chipped stone specimens is quite small, and this is an indication that the average size of the original raw materials also was relatively small; (3) a majority of the flake debitage has features of either hard or soft hammer percussion, but a significant percentage has either features of both methods, or they retain no distinctive features at all; (4) specimens apparently made by the pressure-flaking method occur in the sample, although artifacts of such small size are often indistinguishable from other small debitage; and (5) a majority of the reduction of flint pebbles (and possibly some small cobbles) was done by a stone-working method termed Hammer-Anvil Percussion. This method is often called bipolar flaking or bipolar percussion and has been discussed by many analysts such as Hayden (1980) and Dockall (in Brewington et al. 1995).

\section{Lithic Raw Materials}

As analysis of the lithic debitage progressed it was soon apparent that most artifacts were made of locally and regionally available lithic materials (see Banks 1990; Brewington et al. 1995; Dowd 2011), and they were distinctly small. Also common for this region, a great majority of the artifacts are various kinds of chert, with jasper and flint being the most abundant kinds (for descriptions of chert and flint, see Leudtke [1992]). The source of the jasper is Red River gravels, but most of the flint is from unknown, possibly numerous, sources. A total of eight kinds of lithic materials have been identified in the sample, but only four kinds are represented by more than five specimens. 
By far the most abundant raw material represented in the flake debitage is Red River jasper (Dowd 2011) with 370 specimens, or 71 percent of the total of 522 identifiable flakes. This material occurs in the region as small gravels, being mostly of pebble size $(<64 \mathrm{~mm})$ and small cobble size $(>64 \mathrm{~mm})$, and it is commonly found in the uplands between drainages and along stream beds in the Red River drainage, especially. According to Larry Banks (personal communications, 1995 and 2013), the most common siliceous stone resource in the Big Cypress Creek drainage is chert, occurring as small gravels of various colors. Red River jasper is also said to be less common than chert in the Big Cypress drainage. Bo Nelson (2013 personal communication) affirms that Red River jasper occurs in the Big Cypress drainage, along with chert, quartzite, and petrified wood. In the Wentworth Scale, most of the pebbles used at Mound Pond would be classified as very coarse gravel (30-60 mm). Red River jasper has been called claystone and/or siltstone for many years (Perttula and Nelson 2011).

The 72 reduced pebbles of Red River jasper account for 68.6 percent of the 105 cores in the sample, a frequency very close to that of the flake debitage. The largest of these core fragments, termed Reduced Pebble Fragments (RPF), are only $50 \mathrm{~mm}$ in maximum dimension. Some RPF are of such small size as to have precluded any chance of successful reduction, yet they were broken in apparent attempts to produce something useful. Approximately 33 percent of $105 \mathrm{RPF}$ specimens are fewer than $30 \mathrm{~mm}$ in greatest dimension.

Of the very small sample of chipped stone tools available for analysis from the Mound Pond site, 74 percent are made of Red River jasper. Thus, in all three of the major artifact categories - flakes, cores, and tools - the frequency of Red River jasper averages around 70 percent.

The second most abundant raw material at Mound Pond is classified as flint, with 107 specimens of flake debitage, or 20.3 percent of the flake sample. There are 30 flint cores, which are 28.6 percent of the $105 \mathrm{RPF}$ (cores). The flint sample consists of various materials which often have a more glassy character than the Red River jasper, and come in a wider range of colors and textures. Translucency is common in this sample, and it is suspected that a substantial percentage of the flint debitage is from non-local sources. If this were as much as 33 percent of the flint flake sample, that would amount to no more than 7 percent of the total. A fair amount resembles materials that could be found in Red River gravels, and other varieties appear to be from farther afield in Arkansas, Oklahoma, and Texas. Only one specimen is novaculite and it is from Arkansas, Oklahoma, or Red River gravels, and there is another piece that resembles Woodford chert from a Southeast Oklahoma source area (there is also an undescribed biface of novaculite; see End Note 1).

Another 10-20 percent of the flint debitage resembles raw materials available to the west along the Trinity River drainage, and farther west. Various shades of gray, tan, and brown are common in this material. One fragment of a fairly large flake is a gray, glassy, flint that may have come from Central Texas.

A single small flake of Manning Fused Glass (Brown 1976) suggests that at least minor amounts of most lithic materials available across the southwestern Caddo area made their way to the Mound Pond site. This flake almost certainly was removed at the Mound Pond site from a core, preform, or tool that had been brought there.

The third most abundant lithic material is fine-grained quartzite, but there are only 15 flakes (ca. 3 percent of the debitage) and one core (RPF). This material is sometimes referred to as Potter Chert or Ogallala quartzite, and it is fairly abundant in certain locales generally to the west of the site. Another lithic material common in certain parts of East Texas is silicified wood, but it totaled only eight flakes (1.5 percent) and two cores (RPF). Silicified wood is much more common on sites to the south and 
southwest in East Texas. The fifth most numerous material is a medium/coarse-grained quartzite, and it is represented by five flakes (1 percent).

\section{Diagnostic Tools, Non-Diagnostic Tools, and Tool Preforms}

A modest sample of diagnostic tools and other tools was recovered at the Mound Pond site, but only a very small number is available for analysis. The reason for this is that only the small number can be found today, and the whereabouts of the larger sample is not known. According to the Specimen Inventory, part of the cataloguing was done at TARL in August 1991, and this was then continued in January 1992 by the same student. A much smaller amount of the cataloguing was done by another student, but this work is undated. ${ }^{1}$

\section{Arrow Point Fragments}

There are four arrow point fragments in the sample. One of these is sufficiently complete to allow confident identification.

Specimen 53 (Figure 19a) is a basal and shoulder fragment. The stem is expanding/bulbar and the one remaining barb is upturned toward the distal tip. The lateral edge of the blade, which begins at the barb, is recurved, but extends only $3.5 \mathrm{~mm}$ to where the point is broken. The configuration of stem, barb, and blade resembles the Friley type (Suhm and Jelks 1962). This fragment is almost $3 \mathrm{~mm}$ in thickness and is made of multi-colored yellow and brown Red River jasper.

Also in Lot 53 are two other fragments from what may have been completed arrow points, but they cannot be identified as to type: one is a distal tip and the other is a medial fragment with one straight shoulder, but without the stem. The tip is made of pink and yellowish flint, while the medial fragment is a yellowish-brown Red River jasper. The fourth fragment (Lot 353) is very small, having one square shoulder and a portion of a short stem that was expanding with a concave base. This fragment is made of glossy olive-brown Red River jasper.

\section{Arrow Point Preforms}

There is one unbroken arrow point preform (see Figure 19b) in this sample, but it could not be reduced further due to excessive thickness. Also from Lot 53, its dimensions are: length, $19 \mathrm{~mm}$; width, 15 $\mathrm{mm}$; and thickness, $5.5 \mathrm{~mm}$. Although this specimen was too thick and small to finish into an arrow point, the artisan managed to preserve a small amount of red color at the tip. This was a common, colorful feature of regional arrow point manufacture; this preform is made of yellowish-brown Red River jasper.

A second specimen is a fragment of a preform that was still thick when broken by exposure to heat. Its red color is at least partly due to heat exposure; it is almost $6 \mathrm{~mm}$ thick and appears to be made of Red River jasper.

A third preform, from Lot 327 (see Figure 19c) is a small, thin, triangular specimen that was discarded when the stem was broken. Its thickness is $3.3 \mathrm{~mm}$ and it is made of the red variety of Red River jasper.

\section{Biface Fragments}

Specimen 309 is a medial fragment of a biface made of coarse-grained gray to light brown quartzite. It was broken by at least one snap fracture, being a tough material that is difficult to work. The biface is 


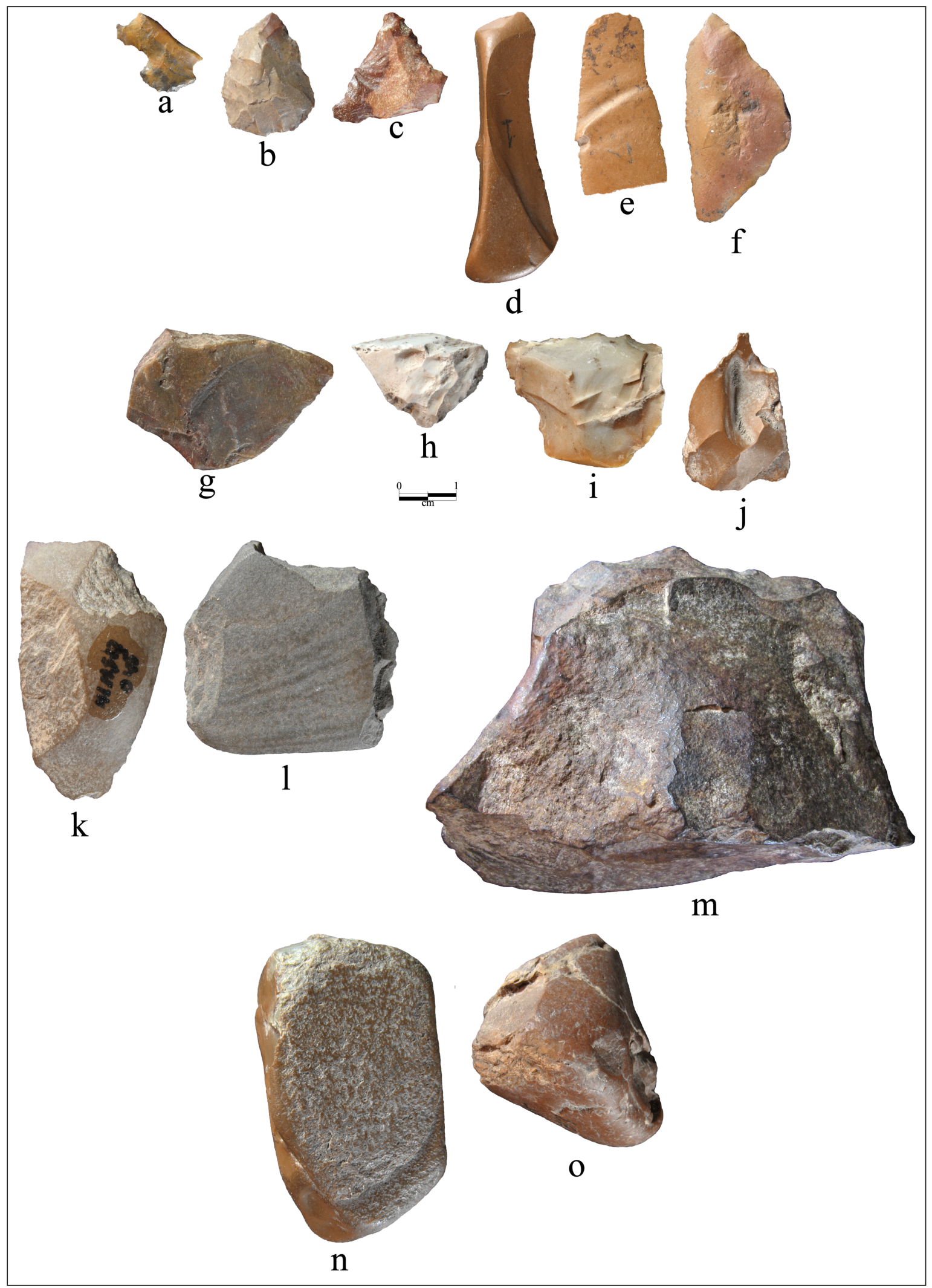

Figure 19. Selected tools from Mound Pond: a, arrow point; b-c, arrow point preforms; d-h, modified flakes; i-j, chipped pebble fragments; k-l, ground stone tool fragments; $\mathbf{m}$, chipped and smoothed hematite; n-o, hammerstones. 
$37 \mathrm{~mm}$ in greatest dimension and its thickness $(9.7 \mathrm{~mm})$ suggests that the intended, but never-completed, tool was a biface such as a dart point.

Specimen 007 is a small nondescript biface fragment made of dark red Red River jasper that retains a small area of dark red cortex. Its greatest dimension is $25 \mathrm{~mm}$ and its thickness is $8.5 \mathrm{~mm}$.

Specimen 351 is a small bifacial fragment, made of fine-grained quartzite, with gray-colored cortex in two areas. It is $24 \mathrm{~mm}$ in length, $6 \mathrm{~mm}$ in thickness, and is pink to dark brownish-red in color.

There are two bifacial fragments from Lot 303, both made from thin pebbles and retaining small sections of cortex on opposing surfaces. The specimens, approximately $25 \mathrm{~mm}$ in length, were broken during manufacturing; one is $4.2 \mathrm{~mm}$ in thickness and the other is $6.4 \mathrm{~mm}$ in thickness. They are made of light yellowish-brown Red River jasper, and the very thin cortex is a darker brown color.

Lot 170 has two small, nondescript biface fragments. Both are made of the red variety of Red River jasper.

\section{Modified Flakes}

A small sample of flakes modified by chipping and/or use occurs in the Mound Pond assemblage. Only one of the complete flakes is larger than $40 \mathrm{~mm}$, but these modified flakes are among the larger ones in the assemblage.

Specimens 340 (see Figure 19d) and 030 have use-wear along one lateral edge. The wear occurs as "nicking" (Shafer 1973), in which very small flakes were removed, almost continuously in this case, for a span of $15 \mathrm{~mm}$ on one, and $25 \mathrm{~mm}$ on the other.

Specimen 321 has nicking along sections of two lateral edges. Specimen 175 has edge "trimming" (Shafer 1973) along one edge (10 mm in length); this probably involved the removal of a continuous row of minute flakes with a pressure-flaking tool.

Lot 303 has two specimens (see Figure 19e-f) with edge nicking along one edge. These flakes are made of Red River jasper.

Shaped like a small scraper, Specimen 254 (see Figure 19g) is a sub-triangular flake, wider than long, that has use wear on both lateral edges and the distal edge; its dimensions are length, $21 \mathrm{~mm}$; width, $32 \mathrm{~mm}$; and thickness, $6 \mathrm{~mm}$. The lateral edges are trimmed, rounded, and smooth. The distal edge has discontinuous nicking, rounding, and smoothing from comparatively heavy work for such a small tool. This specimen is made of an unidentified variety of flint; its colors are brown, olive, red, and reddish-brown.

Specimen 61 (see Figure 19h) is a small triangular flake that has use-wear along the distal edge. Its natural shape resembles a very small scraper; its dimensions are: length, $15 \mathrm{~mm}$; width, $22 \mathrm{~mm}$; and thickness, $5 \mathrm{~mm}$. The use removed a continuous row of minute, almost microscopic, flakes. From the right corner of the distal edge a small flake scar extends almost to mid-blade, and removed whatever use-wear was present. This specimen has the only recognized occurrence of age-related patination in the assemblage. The dorsal surface, partly cortical, is the color of milk, and most of the ventral surface is a very pale brown color; the patina obscures the natural color of the flint. 


\section{Chipped Pebble Fragments}

These two specimens are small fragments of pebbles that were minimally chipped following thorough reduction. This reduction was apparently intended to produce useful flakes.

Specimen 218 (see Figure 19i) is a RPF that has a shape similar to a very small scraper. This shape was achieved by the removal of small flakes along two of the three edges; no use-wear is apparent on these edges. This specimen is made of a pale brown flint that has the hard cortex common on gravels.

Specimen 192 (see Figure 19j) is a RPF that broke in a way that created a natural point, such as that common on engraving tools. A few pressure flakes were then removed from one side to better shape the point; however, there is no apparent use-wear visible under low magnification although this appears to be a useful tool.

Specimen 351 is a small pebble fragment that was very minimally chipped following reduction of the original pebble. This chipping resulted in a very rudimentary and apparently unfinished pointed end, which does not appear to have been used.

\section{The Hammer-Anvil Method of Chipped Stone Working}

As previously noted, most of the locally and regionally available lithic raw materials in northeastern Texas are relatively small in size. Judging by the largest cores, core fragments, and flakes found at the Mound Pond site, siliceous lithic materials larger than small cobbles (> $64 \mathrm{~mm}$ ) were not often worked at the site.

When raw materials are as small as were most of the pebbles and small cobbles found here, breaking them is much easier using some kind of hammer-anvil method than it is using just the hands. In many cases it would have been extremely difficult, and in others, impossible, to break such hard stones of such small size, because the extreme force required is such that the hand alone cannot hold the stone immobile when the blow is struck. Thus, anvil stones are believed to have been widely used in this part of the Caddo Area.

Although none have survived, it is likely that non-lithic materials such as rawhide and/or wood were used as anvils for lithic reduction. While anvil stones of good size are solid and unyielding, they are still subject to breakage when harder stones are being broken upon them. This would not be the case with wooden anvils, well-suited for cushioning larger and harder cores. Much smaller wooden anvils, used together with leather pads, are useful when breaking pebbles so small that they need to be held in the hand, because they are too small to hold upon an anvil. Wooden anvils and wooden/leather anvils have been used effectively in lithic knapping experiments by Goode. Anvils, therefore, would seem to have been essential elements of the reduction process at Mound Pond because the lithic resources were generally quite small and almost certainly were challenging to work.

Across this broad region there were limited materials available for anvils, and artifacts of ferruginous sandstone are the only ones known to survive. Artifacts termed pitted stones, usually made of such sandstone, are common in the region and many may have been used as anvils (see Fields and Gadus 2012). Three pitted stones were found at the Mound Pond site (see below). 


\section{Debitage of the Hammer-Anvil Method of Direct Percussion}

The reduction of siliceous pebbles and cobbles by hammer-anvil percussion at Mound Pond created two classes of debitage: cores/fragments and flakes/fragments. Although an undetermined quantity of this debitage is indistinguishable from that of standard hard hammer percussion, a significant amount has characteristics of the hammer-anvil method of reduction.

In the analyzed sample of Mound Pond debitage, 105 specimens can be classified as fragments of cores (Figure 20). However, because of certain distinctive and sometimes unusual features of these fragments - features especially of the hammer-anvil reduction method-another term is used to describe them: Reduced Pebble Fragments (RPF).

This more precise term implies that these objects lack some of the primary features ordinarily associated with the cores of many Archaic and Late Prehistoric assemblages, namely that they lack signs of being reduced in predictable ways that would have rendered obvious useful results; and that they are of significantly smaller size: so small, in fact, that it was often not possible to reduce them in a predictable manner.

In sharp contrast to more typical cores, the Mound Pond pebble cores were so small it appears that often the only thing possible to predict was that the pebbles would break if struck hard enough. Many of these specimens are fewer than $30 \mathrm{~mm}$ in greatest dimension, and are for the most part mere fragments of pebbles. There are a good many in the 30-40 mm range, but few larger than $40 \mathrm{~mm}$ (see Figure 20). The largest cores, which were reduced less, are only slightly larger than these and are called Partially Reduced Pebbles (Figure 21a-h), or Tested Pebbles (Figure 21i-q).

There are other commonly noted features of these RPF. They include (1) percussion blows struck from multiple directions, (2) percussion blows struck from vertical, or very close to it, (3) heavy impact cavities and scars, and occasional intact partial Hertzian cones, (4) shatter and snap breaks, especially if the pebbles were flat, (5) hinge fractures and stacked/multiple fractures, (6) occasional extremely flat ventral surfaces without percussion rings, bulbar prominence, or negative bulbar depressions, and (7) even after some RPF were very small, there were further removals of very small flakes, seemingly useless, by free-hand percussion. In an assemblage of cores the presence of these attributes, several of which may occur on a given specimen, appear to be unmistakable evidence of the hammer-anvil method of siliceous stone reduction. Because just such specimens comprise the entire assemblage of cores from Mound Pond, the hammer-anvil method was clearly the primary way that pebble-sized resources were reduced at the site. Furthermore, this is the only method by which such pebbles could have been reduced with any chance of success.

Of the flake debitage likely associated with the hammer-anvil method at Mound Pond, four categories of flakes were regularly observed. Most notable among these are flakes apparently made by design, as opposed to flakes that were incidental by-products of the reduction process. These include some of the larger and more symmetrical, linear, flakes (termed H-A 1 flakes), some that appear to be of useful size and shape. Some of the distinctive features of HA-1 flakes include: (1) platforms are the rounded-to-flat, cortex-covered, unmodified surface of a pebble; (2) the percussion removal blow was struck at or near vertical; (3) at the point of impact, such blows often produced a quite small semi-cone, which is the bulb of percussion; and (4) there are few, if any, percussion rings on the very flat ventral surface of the flake.

There are only 16 complete and fragmentary specimens that are considered to be H-A 1 flakes. Thus it is reasonable to assume that other useful flakes were turned into tools (Figure 22a-g). 


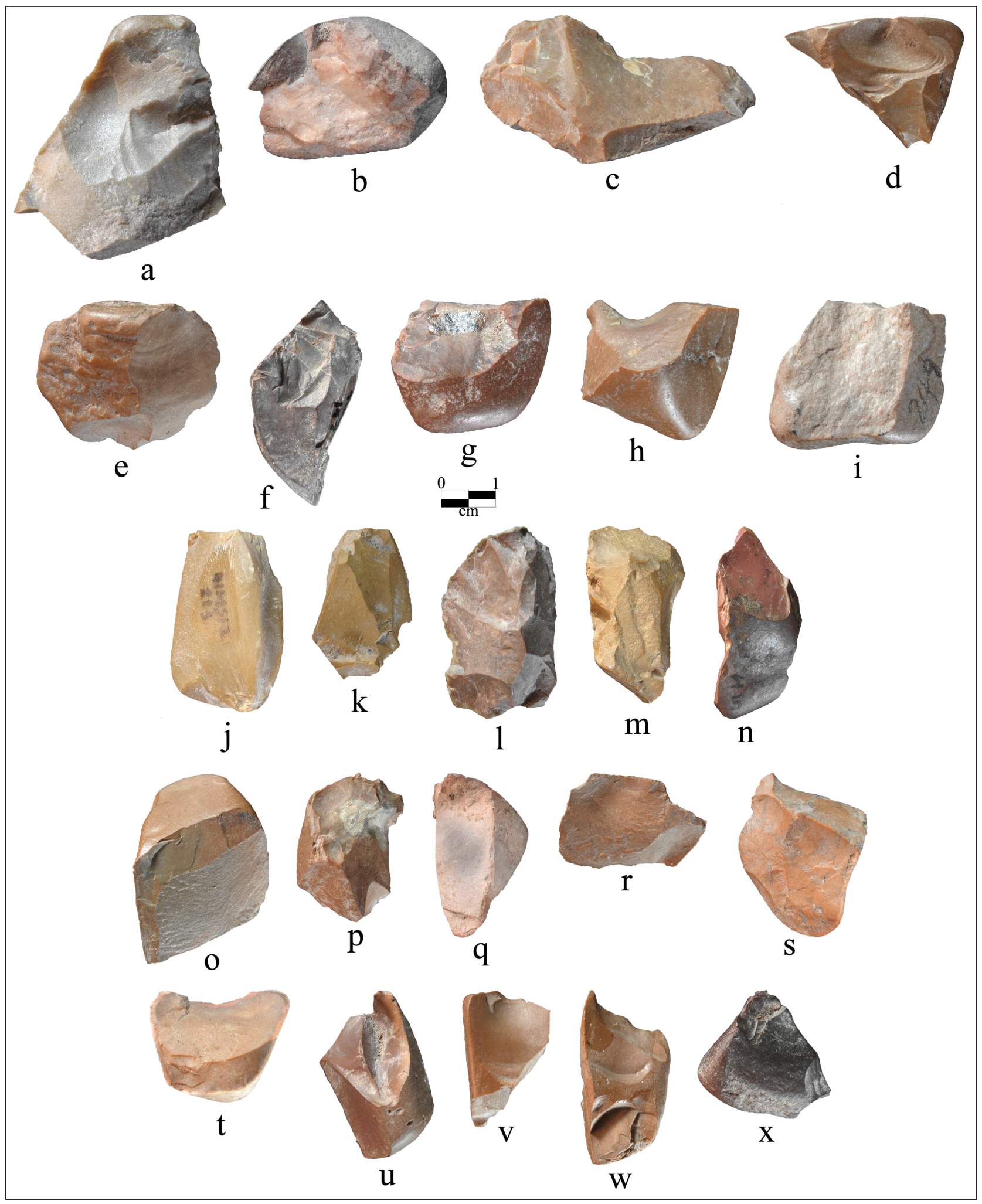

Figure 20. Reduced pebble fragments (RPF). 


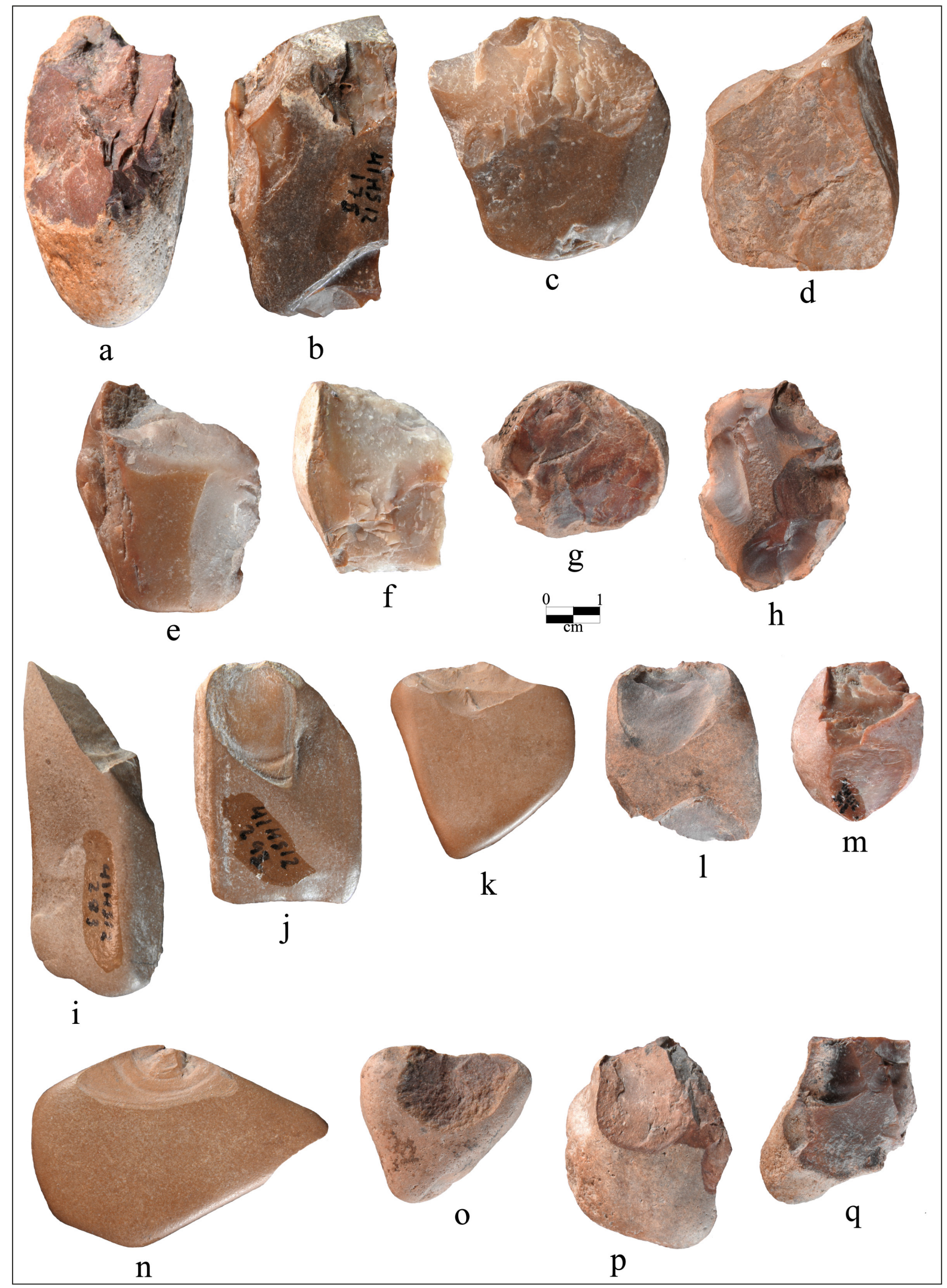

Figure 21. Pebble cores: a-h, partially reduced pebbles; i-q, tested pebbles. 


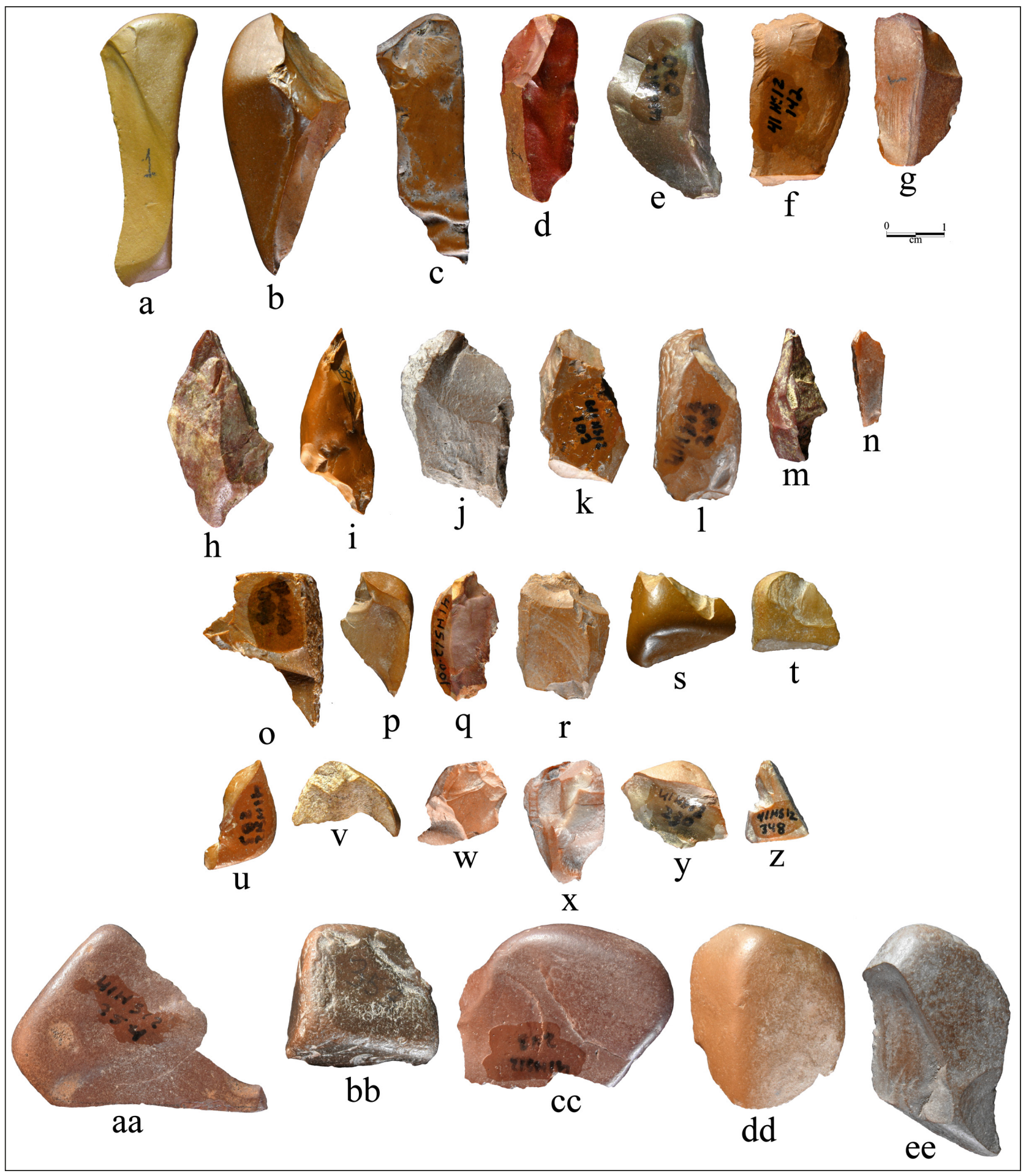

Figure 22. Hammer-anvil flake debitage: a-g, H-A 1 flakes; h-n, H-A 2 flakes; o-z, H-A 3 flakes; aa-ee, H-A 4 flakes. 
The second category of hammer-anvil flakes (H-A 2) is shatter spalls (see Figure 22h-n). They are incidental flakes that tend to be relatively long and narrow. For the most part, these specimens are linear flake fragments, many of which split at the point of percussion and do not retain the platform. Shatter spalls may have the shape of a long triangle, usually being the result of a flake splitting into multiple fragments. The ventral surfaces of these fragments are quite flat and often lack percussion rings, signs that vertical percussion blows also removed these specimens. In addition, they are thick in relation to width, and overall would have been less useful than the more complete flakes; some of these exceed 30 $\mathrm{mm}$ in length, but not $40 \mathrm{~mm}$. None of the H-A 2 flakes has any obvious evidence of usage.

The third kind of flake (H-A 3) from hammer-anvil reduction, also of incidental origin, is the smallest, usually less than $20 \mathrm{~mm}$ in greatest dimension. They are either shatter fragments or irregular flakes (see Figure 22o-z), and the common term chip would apply to some. In addition to usually being too small for meaningful usage, the great majority of H-A 3 flakes are irregularly shaped, and there are no obvious indications that any were used. None of these particular flakes could be demonstrated to be a product of hammer-anvil percussion, but, given the prevalence of the method, many almost certainly are.

Category H-A 4 flakes are some of the larger, thicker, and wider flakes (see Figure 22aa-ee) from Mound Pond. Some of these, while technically flakes, also fit the description of RPF and appear to be prime examples of hammer-anvil reduction. These specimens derive from pebbles so thin that, when struck by percussion blows, some separated into two pieces of nearly equal size, sometimes with the flake section actually being larger than the remaining core section. Such flakes were not made by design, but are common by-products of a reduction method often dependent more on chance than on design and skill. Selected examples of hammer-anvil percussion are presented in Figure 23.

\section{Analysis of all Flake Debitage}

A sample consisting of 522 pieces of flake debitage was analyzed using multiple flake categories with multiple variables applied to each individual specimen. This method of analysis (Goode 2002) entails separating the flake debitage into eight categories based on how the flakes were made, and the completeness of the specimens. Then, several other attributes are examined to complete the analysis. Regarding how flakes are produced, it has been clearly established that the reduction, or knapping, of siliceous stones was done by a very limited number of methods. The methods recognized are (1) hard hammer percussion, (2) hard hammer-anvil percussion, (3) soft hammer percussion, and (4) pressure flaking. There is also a possibility that some work was done by indirect percussion, but such debitage can be difficult or impossible to distinguish.

In the present scheme, Debitage Categories 1 and 2 represent the residue of hard hammer percussion, with Category 1 being complete flakes and Category 2 being incomplete flakes. Categories 3 and 4 are for flakes - complete and incomplete-produced by soft hammer percussion; Categories 5 and 6 are flakes produced by indeterminate means; Category 7 consists of flake fragments lacking platforms; and Category 8 represents shattered fragments from percussion flaking.

The other attributes then applied to these eight categories are: (1) size, (2) color, (3) presence/absence of cortex, (4) presence/absence of thermal alteration, (5) modification by humans, (6) presence/absence of patina, and (7) special attributes such as production by hammer-anvil technique, or nonlocal origin. Inherent in this scheme is the realization that not all flake debitage can be identified as to method of production. Categories 5 and 6 contain the flakes of indeterminate production methods, flakes which, for example, often carry characteristics of both hard and soft hammer percussion, or typical characteristics of neither method. Also possibly subsumed in categories 5 and 6 are certain flakes produced by indirect 


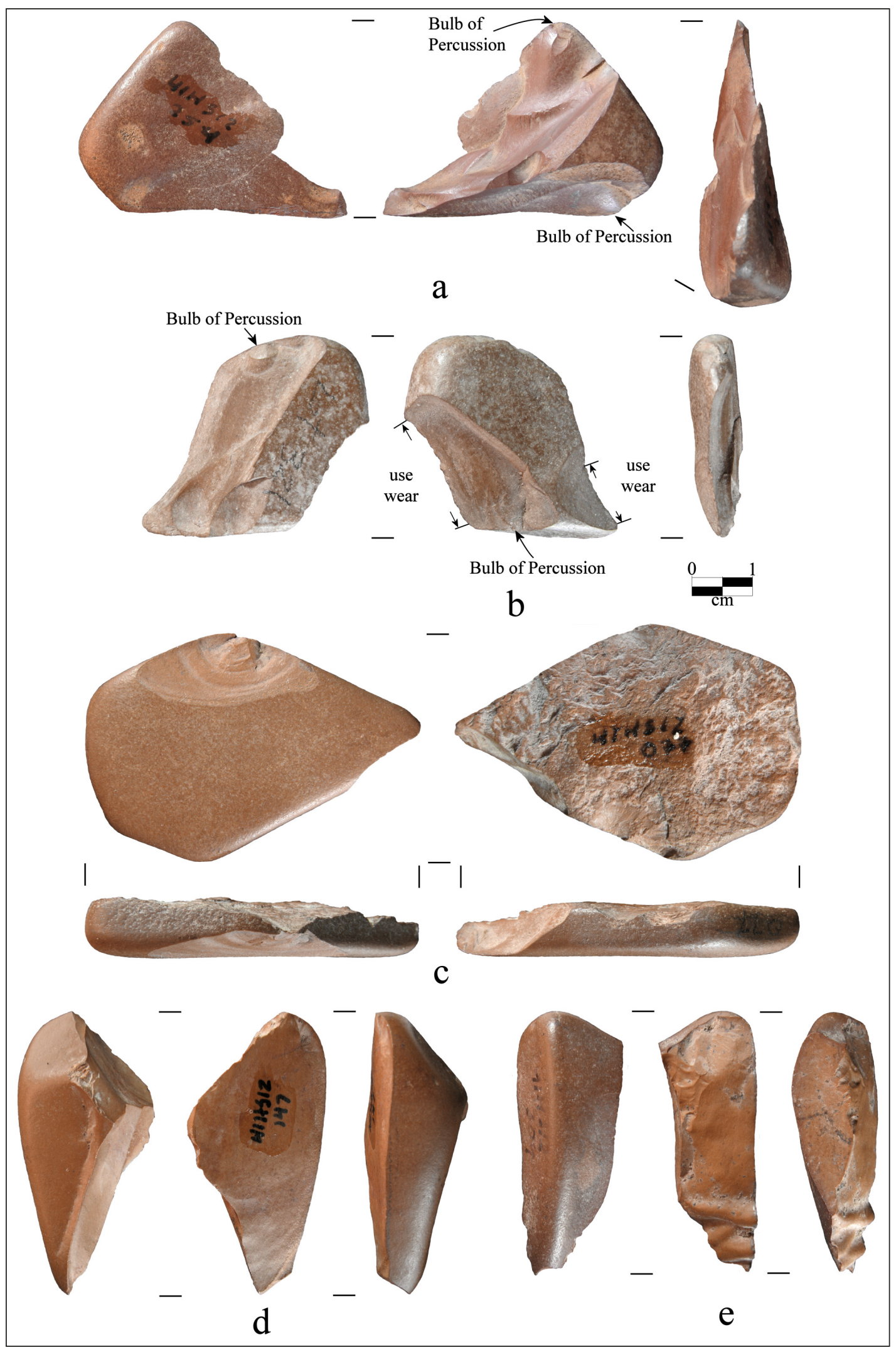

Figure 23. Selected examples of Hammer-anvil reduction. 
percussion or by pressure flaking. Regarding the latter, it is relatively easy to make by hard or soft hammer percussion very small flakes that overlap the characteristics of certain pressure flakes. Therefore, a general rule regarding size is that the smaller the flake, the more difficult it can be to determine how it was made.

\section{Debitage Percentages}

In this assemblage there are 127 hard hammer flakes, 85 soft hammer flakes, and 125 Indeterminate flakes, for a total of 337 specimens with platforms. Comparing all flakes with platforms, then, hard hammer flakes comprise 37.7 percent of the total, the soft hammer flakes 25.2 percent of the total, and the 125 indeterminate flakes another 37.1 percent of the total.

If only the hard hammer and soft hammer flakes are compared, then the figures are 59.9 percent that are hard hammer and 40.1 percent are soft hammer. These percentages, with a majority of hard hammer flakes, are very similar to those of a Late Prehistoric (ca. post-A.D. 1000) component at the Anthon site in southern Uvalde County (Goode 2002), and to several other Late Prehistoric components analyzed by Goode.

But the percentages of hard hammer versus soft hammer flakes from Archaic components at Anthon is just the opposite of the Late Prehistoric figures, as there are considerably more soft hammer flakes. This is a pattern seen at several other Central Texas sites analyzed by Goode, including 41CM25 (Malof et al. 2007), and several other sites analyzed by LeRoy Johnson (1994 personal communication).

The relatively high percentage of indeterminate flakes in the Mound Pond assemblage is likely a result of significant usage of the hammer-anvil method on very small resources, this being a method that often produces flakes without typical features of hard hammer percussion, and most especially without features of soft hammer percussion. In Central Texas assemblages such as Anthon where the hammer-anvil method was not used, the percentage of indeterminate flakes is typically only between 10-20 percent.

The fact that the percentages of platform flakes in the Mound Pond Caddo flake debitage-derived from much different lithic resources and partly by a much different reduction method-closely resembles the percentages of Late Prehistoric (post-A.D. 900) debitage from far away is testimony to the stark difference between Archaic (dating from ca. 8000-500 B.C.) and Late Prehistoric/Caddo stone-working methods. In both areas, East Texas and Central Texas, the post-A.D. 900 flint knapping focus was much more on using hard hammers to make blanks for very small bifaces and flake tools, as opposed to using soft hammers to make larger bifaces. Among Central Texas sites, at least, even in the absence of diagnostic artifacts, this recurring difference in flake debitage is sufficiently reliable to place cultural components in time, as either Archaic or Late Prehistoric there or Archaic/Woodland or Caddo in East Texas, depending on the percentages of hard and soft hammer flakes.

\section{The Attributes as Applied to the Debitage Categories}

Of the seven attributes noted above, Modification and Special Attributes are not discussed in this section. Neither is particularly relevant to this assemblage, and such vestiges of these attributes as exist are subsumed in other discussions.

\section{Attribute 1: Size}

The attribute Size can sometimes be a key to the source and size of lithic resources, and to the kinds of tools that were made at a particular site. As previously stated, it is common knowledge that across 
much of East Texas the native siliceous lithic resources are relatively small; thus, the larger raw materials or tools are often of non-local origin. At the Resch site (Webb et al. 1969) in southern Harrison County, for example, the great majority of tools - dart points, especially-made from local resources are relatively small. Certain larger tools from this site, such as a Motley dart point, are of larger size and made of non-local materials.

At the Mound Pond site, all categories of the lithic artifact assemblage - raw materials, tools, and debitage - are small, and in many cases, they are unusually small. Of tested pebbles, often with only one or two flakes removed, there are only two specimens that exceed $50 \mathrm{~mm}$ in length. Approximately 12 other tested pebbles are between 40 and $50 \mathrm{~mm}$ in length, and several others are less than $40 \mathrm{~mm}$ in length. These are the largest specimens in the collection.

The artifacts classified as cores - herein called RPF - are naturally even smaller due to reduction. The great majority of these 105 depleted pebble fragments are smaller than $40 \mathrm{~mm}$, and more than half are smaller than $30 \mathrm{~mm}$.

Using a coded range of sizes, the size $(\mathrm{Sz})$ of each piece of flake debitage was recorded, as follows: $\mathrm{Sz}$ 1, 1-5 mm; Sz 2, 6-10 mm; Sz 3, 11-20 mm; Sz 4, 21-30 mm; Sz 5, 31-40 mm; Sz 6, 41-50 mm; and Sz 7, 51-60 mm. No Sz 1 specimens were recorded, although many were almost that small. Sz 2 has 55 specimens, or 10.5 percent of the sample. Sz 3 is by the far the most numerous with 338 specimens, or 64.6 percent of the sample. Sz 4 debitage includes 109 specimens (20.8 percent). Sz 5 has 18 specimen (3.4 percent) and Sz 6 has only three specimens (less than 1 percent). More than 75 percent of the artifacts are smaller than $20 \mathrm{~mm}$ and 96 percent are smaller than $30 \mathrm{~mm}$, extremely small materials by any standard.

The overall picture of lithic resource material and artifact size at Mound Pond, then, is one of very small locally and regionally available materials being used perhaps 90 percent of the time. There are three dart points in the collection, and the appreciable amount (40 percent) of soft hammer flakes, suggests that at least some bifaces were made or refurbished here. However, the Caddo occupations are undoubtedly responsible for the great majority of the lithic materials.

\section{Attribute 2: Color}

The attribute color may be a useful clue in identifying raw material sources, and to a moderate extent this is true of the present assemblage, although the primary material, Red River jasper, has a fairly wide color range, but its origin is known to be southeastern Oklahoma and from there it was widely distributed in Red River gravels (Dowd 2011). This material occurs mostly in the common colors of brown, yellow, and red, and there are several shades, as well as combinations, of all three.

A total of 16 colors and combinations of colors was recorded for the debitage. The greatest diversity of color occurs in the flint sample, and a good many colors are represented by only a few specimens, sometimes just a single specimen. Such is the case with the one flake of novaculite, one flake of Woodford chert, and the one flake of Manning Fused Glass. Other than Red River jasper, these appear to be the only specimens sufficiently distinctive to be identified to a particular type of material. As previously observed, a good many sources appear to be represented in the sample of flint. Certain colors and textures of the flints are suggestive of an origin in fairly distant areas such as the drainages of the Trinity and Red rivers (Banks 1990, and 1995 personal communication). 


\section{Attribute 3: Cortex}

The outer rind, or cortex, of siliceous stones can be helpful in determining the sources of raw materials found at a particular site, and can be a good indicator of relative distances to material sources. Cortex is also one of the best indicators of the condition - whether unmodified cobble or bifacial blank - of lithic resources brought to a site.

Cortical material was observed on 336 of the 522 specimens (64 percent). Given that hammer-anvil and other hard hammer percussion methods of reduction were used here on small, cortex-covered pebbles and cobbles, a high percentage of cortex flakes was expected.

The hard hammer flakes have a fairly high incidence of cortical remnants, 59 percent of the sample. The presence of cortical remnants on 41 percent of the soft hammer sample is fairly high, although this amount may be typical of the region. In other regions of Texas, and especially in Archaic assemblages, the incidence of cortex on soft hammer debitage is not nearly so high.

One factor that may explain the high incidence of cortex on soft hammer flakes is that the bifacial blanks used here were generally quite small, apparently used mostly for small unidentified bifaces and arrow points. Thus, it could have been difficult to remove all cortex until very near completion, so that it would not be unusual to find bits of cortex even on final stage thinning flakes. The high incidence of cortex in the Mound Pond assemblage is typical of sites that are reasonably close to the primary materials that were used.

\section{Attribute 4: Thermal Alteration}

Of the 522 pieces of flake debitage, 53 (10.1 percent) have clear evidence of modification by heat. Since thermal alteration at lower intensity can be difficult to detect, there very well were other thermally altered specimens that went unrecognized.

In some cases, it appears that the heating was done intentionally to improve the flaking quality of a bifacial blank, for example. In other cases this was not as clear cut, and it is likely that some, perhaps most, of the heating did not happen intentionally. In any event, thermal alteration does not appear to be a significant feature of the Mound Pond lithic debitage assemblage.

A much larger sample of flint fragments was damaged $(n=248)$, and many pieces were actually created by exposure to excessive heat. None of these fragments are considered to be artifacts but are obviously the result of cultural activity. What precise activities produced the burnt specimens is not known, but they are widespread through the cultural deposits.

\section{Attribute 5: Patination}

The patina commonly found on lithic artifacts, primarily of Archaic age and older, in areas such as Central Texas, can be an indicator of considerable age, but it is never anything approaching a reliable indicator of age. A single artifact with patination was recovered from the Mound Pond test excavation, however. Because of its patination, this flake tool may have originated from a Central Texas lithic source. 


\section{Ground, Battered, and Grooved Stone Tools}

\section{Pitted Stones}

The three pitted stones found at Mound Pond are small cobble-size pieces of ferruginous sandstone. Specimen 332 is roughly sub-rectangular in shape, with a maximum dimension of $96 \mathrm{~mm}$, a width of 86 $\mathrm{mm}$, and a thickness of $44 \mathrm{~mm}$. It has one pit on each face, with the larger, generally circular, one having dimensions of $32 \times 29 \mathrm{~mm}$, and being approximately $10 \mathrm{~mm}$ deep; the surface of this depression is pitted and rough (Figure 24a). The pit on the opposite face has a generally oval shape with dimensions of $34 \times 24 \mathrm{~mm}$, and a depth of approximately $10 \mathrm{~mm}$. The surface of this pit is much smoother than the larger, circular pit. The rough surface of the larger pit could be the result of hammer-anvil flaking, but if the smoother pit was used for flint reduction, a soft material such as leather would have separated the flint from the anvil. Along the right side of the stone and near the edge there is a straight groove that is $48 \mathrm{~mm}$ in length. It ranges from 1.5-3.5 $\mathrm{mm}$ in width and from 1-3 $\mathrm{mm}$ in depth. There are several areas of battering on the stone, from apparent but unknown usage.

Specimen 341 (see Figure 24b) has a fairly large pit on one face, but no evidence of usage elsewhere. This stone has a roughly triangular shape and may have been broken at some point; its dimensions are length, $92 \mathrm{~mm}$; width, $78 \mathrm{~mm}$; and thickness, $57 \mathrm{~mm}$. The pit is generally oval and approximately $44 \times 37$ $\mathrm{mm}$ in size; its depth is approximately $9 \mathrm{~mm}$. The pit surface is somewhat uneven but relatively smooth.

Specimen 137 (see Figure 24c) is a pitted stone that was broken, possibly during use, and has a generally triangular shape; its dimensions are length, $91 \mathrm{~mm}$; width, $71 \mathrm{~mm}$; and thickness, $49 \mathrm{~mm}$. There are two overlapping, shallow pits on one surface but the other is very rough and unmodified. The stone has at least one, and possibly two, fracture surfaces, with one of the fractures running through one of the shallow pits. The complete pit is oval-shaped, with dimensions of $37 \mathrm{x} 25 \mathrm{~mm}$ and a depth of 3-4 $\mathrm{mm}$. The incomplete pit is approximately $2.5 \mathrm{~mm}$ in depth. This specimen is different in that most of the surface outside the pits is lightly to moderately smoothed. This smoothing obviously is not the result of hammer-anvil flaking and the shallow pits probably would have been less useful than deeper ones for that activity.

\section{Ground Stone Tool Fragments}

Specimen 045 (see Figure 19k) is a fragment of a highly smoothed ground stone tool, possibly an axe; it is a fragment of a larger flake, and is $42 \mathrm{~mm}$ in length and $8 \mathrm{~mm}$ in thickness. This flake appears to be a metamorphic rock and it has two flake scars on its dorsal surface. This suggests that the original tool was broken, and then some portion of it was further worked in a refurbishing attempt.

Specimen 342 (see Figure 191) is a fragment, essentially square, of a flat (10 mm thick) and highly smoothed tool of unknown use; its dimensions are length, $32 \mathrm{~mm}$; width, $32 \mathrm{~mm}$; and thickness, $10 \mathrm{~mm}$. Both surfaces are smoothed and one edge remains of the original partially smoothed stone. The square shape was created by flaking the broken tool from three directions, thus creating three of the edges; this specimen appears to be made of indurated sandstone. Artifacts of similar shape and size are sometimes identified as slotting tools or pieces esquilles (Goodyear 1974).

\section{Flat, Smoothed Stones}

Specimen 088 is a flat and thin fragment of ferruginous sandstone. It has a roughly rectangular shape that is the result of four breaks of the original, larger stone; its dimensions are length, $82 \mathrm{~mm}$; width, 


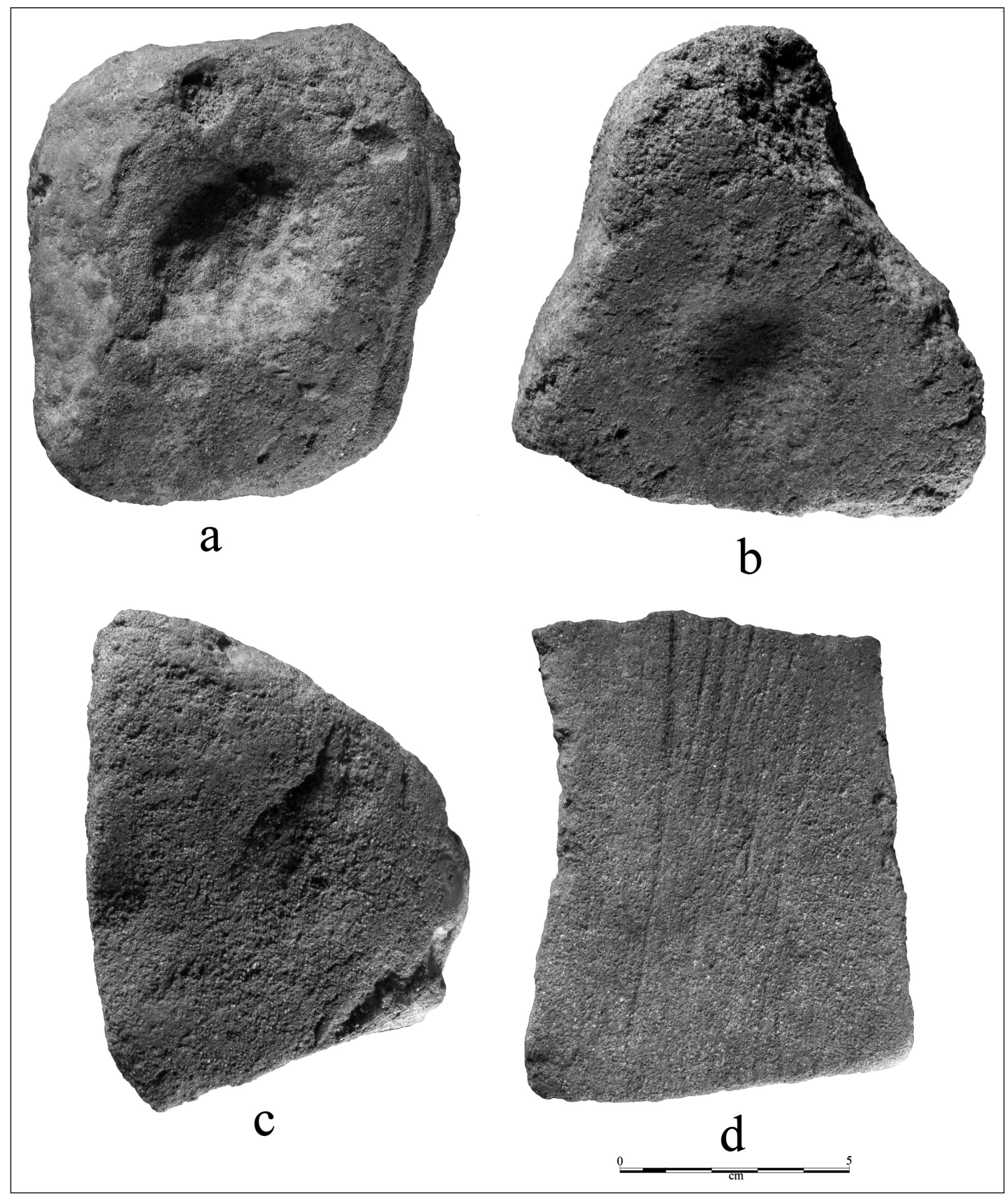

Figure 24. Ground stone tools from the Mound Pond site: a-c, pitted stones; d, smoothed/grooved stone. 
$68 \mathrm{~mm}$; and thickness, $14 \mathrm{~mm}$. The obverse face is mildly convex with a relatively rough and shallowly pitted surface, but there is light to moderate smoothing on the high and/or flat areas. The reverse face is mildly concave, is finer-grained, and not nearly as pitted. Covering the face is light to moderate smoothing from possible usage as a grinding slab. The four breaks mentioned above were intentionally done in a manner that produced a relatively smooth fracture surface, and they were done with a single snap fracture similar to snap-breaking a piece of flint. The edges of the snap-breaks are not worn, thus the specimen was apparently used very little, if at all, after the breaking.

Specimen 104 (see Figure 24d) is a flat and thin fragment of ferruginous sandstone that is a virtual duplicate of Specimen 088, although it is somewhat larger. It has a very similar sub-rectangular shape created by breaking the original stone four times; its dimensions are length, $95 \mathrm{~mm}$; width, $80 \mathrm{~mm}$; and thickness, $14 \mathrm{~mm}$. The obverse face is quite flat, relatively rough and shallowly pitted, and has light smoothing on many of the higher spots. The reverse face is very slightly concave and less rough and pitted; light to moderate smoothing covers most of this surface, but it is not nearly as smooth, or as thick, as metates generally are.

The reverse face on this specimen has a linear area of grooved lines that extend across the long axis, from one broken edge to the other (see Figure 24d). One of the outside lines is the only one that extends unbroken to the opposite edge; it varies from 1-3 $\mathrm{mm}$ in width and 1-2 $\mathrm{mm}$ in depth. The other six or seven lines are distinct at one edge but become indistinct and sporadic across the stone. These lines have been mostly smoothed out by the grinding activity of a tool similar to a mano. These grooves are only 1-1.5 $\mathrm{mm}$ in width and not that deep.

Three of the broken surfaces have one edge that is smoothed for part or all of its length. These edges all adjoin the concave face and the smoothing indicates that the stone was used after breakage, unlike Specimen 088.

\section{Chipped and Smoothed Hematite Fragment}

Specimen 183 (see Figure $19 \mathrm{~m}$ ) is a small cobble-sized fragment of modified hematite that has areas of chipping and other areas of smoothing. In shape, this relatively heavy and dense fragment roughly resembles the bit end of an axe or gouge; its dimensions are length, $52 \mathrm{~mm}$; width, $70 \mathrm{~mm}$; and thickness, $38 \mathrm{~mm}$. One area of chipping is at the bit end and the chipping was done unifacially, producing an edge that is somewhat jagged and rough. Most of this edge is rounded and smoothed from use on some relatively soft material; there is no micro-fracturing of the edge from heavy usage. The opposite end of the specimen is flat and resembles the platform of a flint core. There are flake scars on this surface and several other short flake scars that originate from this surface, and run down the sides of the specimen. Along one edge of the flat platform surface there is a narrow linear area that is highly smoothed; this smoothed area was larger but was reduced by the removal of flakes. Most of the high spots along the edges are rounded and smoothed; the manner of usage is unknown.

\section{Hammerstones}

Specimen 348 (see Figure 19n) and Specimen 237 (see Figure 19o) are angular flint pebbles that appear to have been minimally used as hammerstones. Specimen 348 is $40 \mathrm{~mm}$ in length, $30 \mathrm{~mm}$ in width, and $22 \mathrm{~mm}$ in thickness; Specimen 237 is $30 \mathrm{~mm}$ in length, $28 \mathrm{~mm}$ in width, and $26 \mathrm{~mm}$ in thickness. Both have pronounced battering along one edge where three facets meet. The cortex of Specimen 348 is glossy brown, while the cortex of Specimen 237 is dull brownish-red; both appear to be some material other than Red River jasper. While hammerstones of such small size probably could not 
have been used effectively in hammer-anvil reduction, they would have been useful in knapping activities such as platform preparation.

\section{Lithic Assemblage Summary}

The assemblage of lithic materials recovered at the Mound Pond site is apparently almost totally of Caddo origin. As such, it allows for the analysis of Caddo resource collection and tool-making strategies. The location of this site, on Big Cypress Bayou not far west of the Texas-Louisiana line, is somewhat off the beaten path in terms of availability of siliceous stone resources. Locally available materials are not known to be abundant and most definitely are not of large, or even medium, size. Mound Pond is a fair distance from all of the more abundant materials of East Texas, such as the fine-grained quartzite and flint gravels to the west, and the silicified wood to the southwest. Certain abundant resources of Oklahoma and Arkansas also are quite distant, so the primary material found at Mound Pond is Red River jasper, along with flint gravels also primarily from the Red River drainage.

The generally small size of their lithic resources presented certain challenges to stone workers at Mound Pond, challenges that were not easily overcome and often times not at all. Judging by just how small some of the tested cores are, it may be fair to say that the flint knappers were literally desperate in trying to break them. Many were impossible to break into something useful, and many that were broken were successfully split only by resorting to the hammer-anvil method of stone working. Possible anvils used for this purpose at Mound Pond occur in the form of two of the three pitted stones of ferruginous sandstone in the assemblage. Since we do not know exactly how the anvils were used, we can only speculate about the wear on them caused by lithic reduction. There is also the likelihood that wood and leather, separately or together, were used as anvils, or as support for stone anvils. Experiments by Goode using wood and/or leather as anvils to aid reduction of flint pebbles have been successful.

At Mound Pond, hammer-anvil percussion was used to reduce pebbles into useful pieces such as flake blanks that were turned into several kinds of tools. Arrow points are the most numerous of these, and there are small numbers of unifaces, perforators, and utilized flakes used without prior modification by chipping. Hammer-anvil reduction produces certain debitage that is sometimes quite distinctive, and this includes cores and three or four classes of flakes. Identifying certain hammer-anvil debitage is often aided by the small size and shape of specimens, especially when the parameters of lithic resources demand the hammer-anvil method for any chance of successful reduction. Much debitage, however, cannot be assigned to any particular method of reduction with certainty; therefore, it is not possible to quantify the degree of hammer-anvil usage at Mound Pond, beyond saying that the method was used frequently for the smaller resources.

Among the Mound Pond debitage there are certain larger flakes and core fragments that undoubtedly were reduced by standard free-hand percussion using hard hammerstones, which often produce unmistakable debitage. Considerably more accuracy and reliability are inherent in this method; thus, it would have been used whenever possible on the larger pebbles and small cobbles. While hard hammers are necessary for initial reduction of many raw materials - such as siliceous gravels of whatever size - they are also the best tool for making platforms on bifaces of all but the smallest sizes. Naturally, as bifacial blanks become smaller preforms, there is a concomitant reduction in the size of the hard hammers, often seen as small abrading/chipping stones of quartzite or indurated sandstone. Bifacial blanks and preforms, then, were often further reduced and almost finished by soft hammer percussion, using tools such as batons of antler, and this produces debitage that is quite distinctive. Compared to the hard hammer debitage (60 percent), 40 percent of the flake debitage was produced by soft hammer percussion. This finding-more 
hard-hammer than soft-hammer debitage-reflects a trend typical for this region (as it is for others) and for the period after ca. A.D. 800 and to the 14th century A.D.

Arrow points would have been made almost strictly by pressure flaking and some of the smallest debitage very likely comes from such work. Other bifaces such as dart points were also finished by pressure flaking, so a fair sample of pressure flakes is to be expected in the assemblage. The problem with identifying pressure flakes, beyond the fact that many shatter into tiny fragments, is that small flakes resembling pressure flakes are frequently made by small percussion tools. The indirect percussion method of stone working was possibly also used at Mound Pond.

Other than arrow points and arrow point preforms, the only bifaces available for analysis are a few very small fragments. The missing specimens would have been helpful in providing a better picture of the movement of lithic materials on a regional scale. For example, the one biface cited as being made from novaculite likely traveled a fair distance before ending up at Mound Pond. While it is possible that the one flake of novaculite found at the site came from this biface, just as likely it did not: the main point of this being that only two artifacts of this desirable material are known from the site.

The non-siliceous, ground stone tools used at Mound Pond constitute a modest sample including several common tool forms of the region. Included is a possible fragment of an axe, a possible slotting tool (also chipped), pitted stones, and a smoothed and chipped fragment of hematite. A flat and thin fragment of ferruginous sandstone is smoothed from apparent grinding, and has a series of parallel, shallow grooves on it.

The overall picture of chipped stone tool manufacture and use at the Mound Pond site, then, is one of reliance primarily on small, locally available siliceous gravels; but non-local materials are also present. Reduction of these resources often required a hammer-anvil technology, practiced across a broad region, wherever such small resources were needed. These characteristics, and all others involving regional chipped-stone working, are reflected in the lithic assemblage of Mound Pond. Arrow points are the most common tool, other bifaces are neither numerous nor large, true unifaces are rare, and utilized flakes are fairly common. All in all, the Mound Pond lithic assemblage is typical of the time and region, and if it contains elements of Archaic use, they apparently occur in insignificant numbers. 


\title{
Chapter 5, Ceramic Vessel Sherds and other Clay Artifacts
}

\author{
Timothy K. Perttula and P. Shawn Marceaux
}

The assemblage of ceramic vessel sherds from the Mound Pond site totals 3071 sherds. Approximately 80 percent of the sherds are plain (either plain rims from plain vessels or the plain body and base sherds from plain or decorated vessels), and the remainder are decorated with a variety of design elements and motifs. The analysis of the plain and decorated sherds from the site follow the protocols outlined by Perttula (2010:29-30).

\section{Plain Rim, Body, and Base Sherds from the Mound Pond site}

\section{Shawn Marceaux}

The ceramic assemblage from the Mound Pond site (41HS12) includes a substantial number of plain sherds. Documentation from inventory forms in the files at the Texas Archeological Research Laboratory (TARL) suggests that previous investigations recovered more than 1,400 plain sherds from mound deposits, over 480 plain sherds from midden deposits below the mound, and 74 plain sherds from Area B. An examination of the collected materials (including the bag inventory tags with total numbers of sherds listed on them) indicates that the total number of plain sherds in the Mound Pond site collection that has been stored at TARL is in fact around 2,474. It is also clear that previous efforts sorted and bagged most, although not all, of the plain sherds into categories of rim, base, or body. The plain sherds in the collection were not organized by any other attributes (i.e., temper, paste, and/or provenience).

For this analysis, I have examined a sample (about 11 percent) of these plain sherds for characteristics related to ceramic production and technology. Specifically, this analysis focused on the rim form, the lip form, and the vessel form, if possible, of the plain sherds as well as characteristics of temper and paste, firing conditions, surface treatment, and the thickness of plain sherds (Appendix 3).

Of particular interest were the plain rims, then large plain body sherds, and finally a small number of plain base sherds. An effort was made to select sherds for detailed analysis that were obviously from different vessels as well. Using lot numbers to identify specific contexts, I selected a sample of plain rim $(n=44)$, base $(n=15)$, and body $(n=208)$ sherds from three different areas of the site for detailed study: the mound, the sub-mound midden deposit, and Area B, a habitation area near the mound.

\section{Comparisons of Plain Rim and Lip Forms}

The large number of plain rim sherds recovered from the Mound Pond site-even disregarding the rim sherds that are so small that it is virtually impossible to discern whether they are from a plain or decorated vessel-suggests plain vessels are abundant in the ceramic assemblage. Rim sherds indicate the plain vessels likely include simple bowls, carinated bowls, bottles, and jars. There are also at least six body sherds from carinated bowls that have been broken at the point of carination (four of these sherds are from the mound deposits and two sherds are from sub-mound midden deposits). There are no plain rims from Area B.

The primary rim form for plain vessels, around 90 percent of those identified, is a direct or vertical rim (Table 3). Most of these rims are likely from simple bowls or carinated bowls (as are the inverted rim vessels), but there is also at least one plain bottle and rims from perhaps several plain jars. Only two 
examples of inverted rims are present in the assemblage, one from the mound deposits and the other from the midden deposits below the mound.

Table 3. Plain rim and lip forms in the Mound Pond site ceramic assemblage.

\begin{tabular}{lll}
\hline Rim form-lip form & Mound & Sub-Mound \\
\hline Direct rim-flat lip & $16.7^{*}$ & 10.0 \\
Direct rim-rounded lip & 37.5 & 30.0 \\
Direct rim-thinned lip & 4.2 & 5.0 \\
Inverted rim-rounded lip & 4.2 & 5.0 \\
& & \\
? rim-flat lip & 4.2 & 15.0 \\
? rim-rounded lip & 33.3 & 30.0 \\
? rim-rounded lip, folded outward & - & 5.0 \\
& & \\
Summary of Rim and Lip Forms & & \\
& 93.3 & 90.0 \\
Direct rim & 6.7 & 10.0 \\
Inverted rim & & 25.0 \\
Flat lip & 20.8 & 5.0 \\
Thinned lip & 7.2 & 65.0 \\
Rounded lip & - & 5.0 \\
Rounded lip, folded outward &
\end{tabular}

*percentage

Overall, rim and lip attributes from the mound and sub-mound deposits are comparable. Direct rims recovered from the two areas have several types of lip forms. Rounded lips are most frequent (30-37.5 percent), followed by flat lips (10-16.7 percent) and thinned lips (4.2-5 percent). In contrast, the only lip attribute on inverted rims is a rounded lip (4.2-5 percent).

Irrespective of rim form, rounded lips appear on three-quarters of the plain rim sherds from mound deposits. Rounded lips occur in slightly smaller amounts in the sub-mound midden deposits, but there is also one vessel with a rounded lip that has been folded outward. Flat lips and thinned lips are more common in the sub-mound midden deposits. Approximately 30 percent of the plain ware rims from the sub-mound deposits have these two lip attributes, compared to 25 percent of the plain ware rims from the mound.

The plain ware rims with a measurable orifice diameter range from 8 to more than $25 \mathrm{~cm}$ in size. This range in sizes of the plain wares - based on estimated orifice diameters of 10 sherds - suggests that vessels were made for use of individual servings (at the smaller orifice diameter ranges) as well as multiple servings (at the $25+\mathrm{cm}$ orifice diameter range).

According to the estimated orifice diameter, the largest plain vessels are from the mound deposits. This may relate to communal ceremonies associated with a large number of people (i.e., feasting) or other events related to the occupation, construction, or function of the mound. Interestingly, many of the smallest vessels are also recovered in the mound deposits. Vessels from the sub-mound deposits are moderately-sized with estimated orifice diameters that range from $12-19+\mathrm{cm}$. 


\section{Technological Comparisons of Plain Rim, Body, and Base Sherds}

Certain technological attributes of the ceramic vessel sherds from the Mound Pond site can be compared to determine if there are differences in how the vessels were made, fired, and used across the site during its different periods of use by Caddo peoples. The ceramic attribute data reviewed below are based on a detailed examination of a sample of plain rim, base, and body sherds $(n=267)$ from the three different areas identified at the site (see Appendix 3).

The plain vessel sherds are from vessels tempered primarily with grog (fired clay and/or crushed sherds). Grog appears as the sole temper inclusion, and also occurs in conjunction with other types of temper inclusions such as bone and hematite (Table 4). It is also present in more than half of the temper classes. Depending on the area of the site, grog temper inclusions are present in 83.4-96 percent of the sample of sherds. Grog temper use appears to be slightly more common in the sherds from sub-mound midden deposits and Area B (both over 90 percent), but this depends on the specific temper-paste associations found in the vessel sherds. For example, grog and bone occur in combination more frequently in sherds from the mound and Area B (37.7-40 percent) than they do in the sub-mound midden deposits (28.7 percent).

Table 4. Temper classes in the plain ware in the Mound Pond site ceramic assemblage.

\begin{tabular}{llll}
\hline Temper class & Mound & $\begin{array}{l}\text { Sub-Mound } \\
\text { Midden }\end{array}$ & Area B \\
\hline $\begin{array}{l}\text { grog } \\
\text { grog/sandy paste }\end{array}$ & $39.7^{*}$ & 64.4 & 53.3 \\
grog-bone & 1.3 & - & 40.0 \\
grog-hematite & 37.7 & 25.7 & - \\
grog-hematite/sandy paste & 4.0 & 5.9 & - \\
bone & 0.7 & - & - \\
bone/sandy paste & 13.2 & 3.0 & - \\
none/sandy paste & 1.3 & - & \\
Summary of Temper Classes: & & 1.0 & \\
& 2.0 & & 43.3 \\
sherds with grog temper & 83.4 & & - \\
sherds with bone temper & 52.3 & 96.0 & - \\
sherds with hematite temper & 4.6 & 28.7 & \\
sherds with sandy paste & 5.3 & 1.0 & \\
\hline
\end{tabular}

*percentage

As noted, in addition to grog, many of the sherds have crushed and burned bone pieces used as temper. Bone-tempered ceramics are most common in the mound deposits, occurring in just over half of the sampled sherds (see Table 4). There are only minor differences in the frequency of bone temper from Area B (46.7 percent), but more significant differences in the sherds from pre-mound midden deposits (28.7 percent). The percentages of bone as the sole temper inclusion also support the fact that 
bone-tempered vessel sherds are much more common in the mound deposits (14.5 percent) at the Mound Pond site than in Area B (6.7 percent) or the sub-mound midden deposits ( 3 percent).

Temper inclusions found in the paste of plain vessel sherds include the remains of crushed hematite as well (4.6-5.9 percent by area). Hematite temper use occurs exclusively in association with grog temper. Although no hematite was recognized in the sample of sherds from Area B, the amount of sherds with hematite tempering from mound and sub-mound deposits is comparable.

There is little variability in the use of different temper-paste combinations at the Mound Pond site, as there are only eight temper-paste combinations (see Table 4). This is comparable to the low number of temper-paste combinations in early Historic Caddo sites in the upper Neches River basin (see Perttula 2007, 2008a, 2008b), but not nearly as diverse as seen in many other prehistoric Caddo sites; for examples, there were 31 temper-paste combinations at a ca. A.D. 1150-1430 site reported by Perttula and Nelson (2003) in the Angelina River basin in East Texas. This limited number of temper-paste combinations suggests that the ceramics from the Mound Pond site are a product of a well-developed and relatively homogeneous ceramic vessel-making tradition.

The majority of the vessel sherds from the Mound Pond site have a clayey paste. Clays used for vessel manufacture were probably gathered from nearby alluvial settings, most likely within a short (1-7 km away, at most) distance from the settlement (Arnold 2000:343; Arthur 2006:52). This insured that potters hauling clay back to a site did not expend an inordinate amount of time and energy on that task, limiting their production effort. Arthur (2006:52) points out that potters are likely to select lower quality clays for vessel manufacture than high quality clays if the latter are farther away.

Only nine sherds from the detailed sherd analysis sample from the Mound Pond site have a sandy paste, and all but one of these sherds is from the mound deposits (see Table 4). In other words, the highest proportions of sandy paste sherds are from mound deposits (5.3 percent), with lesser amounts among the sherds in the sub-mound deposits ( 1 percent) and none from Area B. Nearly half the sherds with sandy paste have no temper, but the remainder have other inclusions such as grog, bone, or hematite as well.

The Caddo fired plain wares at the Mound Pond site in several different ways, and the cross-section of sherds were examined in order to determine these firing environment conditions. The cross-section reveals the firing core, along with oxidation patterns that occur during the firing or as the vessels cool (Teltser 1993:Figure 2; Perttula 2005:Figure 5-30).

The ceramics wares at Mound Pond were typically fired in a regular or well-controlled fashion inside a bed of coals from an open wood fire. This is indicated by the higher proportions of sherds with cross-sections that indicate the vessels were completely oxidized (A) or reduced (B) during firing, or fired in a reducing environment and then cooled in the open air (F, G, and H). Together, these three categories are present in 82.1 percent of the plain sherds from the mound, 69.2 percent of the plain sherds from sub-mound midden deposits, and 60 percent of the sherds from Area B (Table 5). In the mound deposits and the sub-mound midden deposits, the majority of sherds are from vessels fired in a reducing environment, then cooled in the open air (45.5-60.3 percent), leaving a thin oxidized zone on one or both vessel core surfaces. 
Table 5. Firing conditions in the plain ware sherds in the Mound Pond (41HS12) ceramic assemblage.

\begin{tabular}{llll}
\hline Firing Condition* & Mound & Sub-Mound & Area B \\
\hline A (oxidizing) & $9.3^{* *}$ & 6.9 & 13.3 \\
B (reducing) & 12.6 & 16.8 & 20.0 \\
C & 4.0 & 1.0 & 26.7 \\
D (incompletely & 0.7 & 1.0 & - \\
E oxidized) & 10.6 & 19.8 & 26.7 \\
F & 24.5 & 15.8 & - \\
G (reducing, but & 29.8 & 28.7 & 13.3 \\
H (cooled in open air) & 6.0 & 1.0 & - \\
I & - & 4.0 & - \\
J (sooted, smudged, & 0.7 & - & - \\
K reheated) & 0.7 & 2.0 & - \\
L & 0.7 & 2.0 & \\
X (multiple oxidizing & 0.7 & 1.0 & \\
and reducing zones) & & & \\
\hline
\end{tabular}

*after Teltser (1993:Figure 2) and Perttula (2005:Figure 5-30)

** percentage

The three categories of less controlled or sustained firing includes vessels that were incompletely oxidized during firing (C, D, and E), possibly re-heated, sooted, or smudged (I, J, K, and L), or are sherds that have multiple reducing/oxidizing bands (X). Sherds cross-sections indicate these categories comprise 18.1 percent of the plain sherds from the mound, 30.8 percent of the plain sherds from sub-mound midden deposits, and 40 percent of the sherds from Area B.

It does appear that sherds from the mound and sub-mound deposits are from vessels that were fired in a similar manner (see Table 5). For example, these areas have comparable proportions of oxidized (6.99.3 percent), incompletely oxidized (15.3-21.8 percent), and reduced (12.6-16.8 percent) firing conditions. As mentioned above, the rates of reduced firing conditions, with subsequent cooling of the vessel in the open air (45.5-60.3 percent), are also much different from Area B (26.7 percent). Firing conditions tend to be more heterogeneous among the sherds from Area B, although this may be due to the small sample size from this part of the site.

Many of the vessel sherds from the Mound Pond site retain evidence of the smoothing of interior and/or exterior surfaces (Table 6). These surface treatments were done to thin and even out the vessel surfaces, strengthen them by melding coil joins, and even to create a surface appearance that enhanced the vessel decoration. In all likelihood, smoothing (especially smoothing on vessel interior surfaces) was consistently done to lower the permeability and increase the heating effectiveness of particular vessels (cf. Rice 1996:148). 
Table 6. Surface treatment in the plain ware sherds in the Mound Pond site ceramic assemblage.

\begin{tabular}{llll}
\hline Surface Treatment & Mound & Sub-Mound & Area B \\
\hline Interior smoothed & $47.7^{*}$ & 86.1 & 60.0 \\
Exterior smoothed & 50.3 & 88.1 & 26.7 \\
\hline
\end{tabular}

*percentage

It appears that the plain ware vessel sherds from sub-mound midden deposits have smoothed surfaces more frequently than the plain sherds from other areas (see Table 6); this may be a product of the fact that the sherds were well-preserved in the midden deposits, which tends to better preserve and not erode sherd surfaces. Surface smoothing on the interior and exterior surfaces of sherds from sub-mound midden deposits ranges from 86.1-88.1 percent. Around half of the plain sherds from the mound deposits have smoothed surfaces on the interior and exterior surfaces. Although there are differences in the relative proportion of smoothed surface treatments from the two contexts, the interior and exterior surface treatment of vessel sherds is consistent in each of these two areas. In contrast, the surfaces of plain sherds were treated differently in Area B. The interior of plain sherds from Area B have smoothing 60 percent of the time (not very different from the other areas), but only 26.7 percent of the exterior sherd surfaces have been smoothed. The reason for these differences is unclear, but may relative to differences in the kind and character of the vessels made, used, and discarded in these areas. Sub-mound and mound sherds may be the product of the use of more fine wares (which are usually smoothed and/or burnished on both surfaces), compared to a higher use of utility ware jars, which are typically smoothed only on the interior vessel surface.

On average, the plain wares from each of the areas at the Mound Pond site are thin-walled, with a sturdy, flat, and thick base. The mean thickness for rim and body sherds from the different areas of the site varies only from 5.9-6.8 $\mathrm{mm}$ in width (Table 7), with a one standard deviation range in the mean of 4.8-8.5 $\mathrm{mm}$. The relatively thick bases, constructed to be flat and disk-shaped for stability, have mean thicknesses of 10.6-14.6 mm in width. The sub-mound midden sherds are consistently thicker than the sherds from the mound deposits, on the order of 30-40 percent of one standard deviation for the rim and body sherds, and with a one standard deviation difference between the base sherds.

Table 7. Mean thickness of rim, body, and base sherds in the plain, utility, and fine wares.

\begin{tabular}{llll}
\hline Provenience & $\begin{array}{l}\text { Rim } \\
(\mathbf{m m})\end{array}$ & $\begin{array}{l}\text { Body } \\
(\mathbf{m m})\end{array}$ & $\begin{array}{l}\text { Base } \\
(\mathbf{m m})\end{array}$ \\
\hline Mound & $6.2 \pm 1.4(\mathrm{n}=24)$ & $6.3 \pm 1.4(\mathrm{n}=117)$ & $10.6 \pm 2.0(\mathrm{n}=10)$ \\
Sub-Mound & $6.7 \pm 1.8(\mathrm{n}=20)$ & $6.8 \pm 1.2(\mathrm{n}=76)$ & $14.6 \pm 3.9(\mathrm{n}=5)$ \\
Area B & - & $5.9 \pm 1.0(\mathrm{n}=15)$ & - \\
\hline
\end{tabular}

The rim sherds from the mound deposits range from 3.9-8.7 mm, the body sherds range from 3.5$10.4 \mathrm{~mm}$, and the base sherds range from $6.8-13.1 \mathrm{~mm}$. The rim sherds from sub-mound deposits range from 3.8-10 mm, the body sherds range from 4.6-10.7 mm, and the base sherds range from 8.3-17.9 mm. The generally thicker sherds from the sub-mound deposits may relate to the earlier period of occupation represented by those ceramics compared to the sherds from overlying mound deposits. 


\section{Decorated Sherds}

\section{Timothy K. Perttula}

There are 597 decorated sherds in the Mound Pond ceramic assemblage, most of them from mound deposits (70 percent) (Table 8 ). About 22 percent of the decorated sherds are from the sub-midden midden deposits, 2 percent are from Area B, and 7 percent have no provenience information (i.e., the sherd is not labeled with a lot number). With 2474 plain rim, body, and base sherds, the plain to decorated sherd ratio $(\mathrm{P} / \mathrm{DR})$ for the assemblage as a whole is 4.14. As has been discussed on several occasions, this P/DR is consistent with other pre-A.D. 1200 Caddo ceramic assemblages in much of East Texas. Looking at Early Caddo to Historic Caddo ceramic assemblages in the region through time, ceramic assemblages have lower proportions of undecorated sherds through time and thus a lower P/DR ratio (Perttula 2008a:9, 315-317). Analyzed pre-A.D. 1200 sites have plain/decorated sherd ratios that range between 2.97-4.80. Middle Caddo sites (ca. A.D. 1200-1450) have ratios that range between 1.30-2.65. In known Late Caddo sites in the Neches, Angelina, and Sabine River basins, by contrast, the P/DR ranges from only 1.30-0.47. Finally, post-A.D. 1680 Caddo occupations in the Neches-Angelina river basin have $\mathrm{P} / \mathrm{DR}$ ratios that range from $0.20-0.30$.

Table 8. Decorated sherds from the Mound Pond site (41HS12).

\begin{tabular}{|c|c|c|c|}
\hline Decorative Method & $\begin{array}{l}\text { Mound } \\
\mathrm{n} / \%\end{array}$ & $\begin{array}{l}\text { Midden } \\
\mathrm{n} / \%\end{array}$ & $\begin{array}{l}\text { Area B } \\
\mathrm{n} / \%\end{array}$ \\
\hline Engraved & $28 / 6.8 \%$ & $5 / 3.8 \%$ & $\underline{2 / 18 \%}$ \\
\hline Incised & $252 / 61 \%$ & $\underline{116 / 87 \%}$ & $6 / 55 \%$ \\
\hline Incised-Pinched & $1 / 0.2 \%$ & - & - \\
\hline Incised-Punctated & $\underline{64 / 15.5 \%}$ & $2 / 1.5 \%$ & - \\
\hline Incised-impressed triangles & $2 / 0.5 \%$ & $\underline{6 / 4.5 \%}$ & - \\
\hline Impressed Triangles & - & $1 / 0.8 \%$ & - \\
\hline Pinched & $4 / 1.0 \%$ & $2 / 1.5 \%$ & - \\
\hline Punctated & $49 / 11.9 \%$ & $1 / 0.8 \%$ & $\underline{2 / 18 \%}$ \\
\hline Band Punctated & $4 / 1 \%$ & - & $\underline{1 / 9 \%}$ \\
\hline Punctated-Pinched & $1 / 0.2 \%$ & - & - \\
\hline Slipped & $\underline{8 / 2 \%}$ & - & - \\
\hline Totals & $413 / 100 \%$ & $133 / 100 \%$ & $11 / 100 \%$ \\
\hline
\end{tabular}

note: bolded column entries represent significantly different ceramic proportions by provenience 
Although the sherd sample sizes are not comparable from one provenience to another (see Table 8), the proportions of the different decorative methods represented in the sherds indicate that the ceramics from each provenience may not be contemporaneous. The midden deposits under the mound are dominated by sherds from incised vessels, many of the Coles Creek Incised type, as well as sherds from vessels with incised lines and impressed triangles (also Coles Creek Incised) (see Table 8), and a few engraved, pinched, punctated, and incised-punctated vessel sherds. Incised sherds remain common in both the Mound and Area B assemblages, but with few Coles Creek Incised vessel sherds. More common in these two assemblages, which both date later than the sub-mound midden deposit, are incised-punctated, punctated, band punctated, engraved, and slipped sherds.

\section{Mound Deposits}

The decorated ceramic sherds from the mound deposits have the widest diversity of decorative methods and elements in the Mound Pond ceramic assemblage, but this may simply be a product of the much larger sample $(n=413)$ compared to the sub-mound midden $(n=133)$, and Area $B(n=11)$. The majority of the decorated sherds are from vessels decorated with incised lines, incised-punctated elements, or punctations made by different wood or cane tools as well as fingernails.

Fine ware sherds in the mound deposits account for only 8.7 percent of the decorated assemblage (see Table 8), and 11.3 percent of the rim sherds. These fine wares, in turn, are sorted into engraved (78 percent) and slipped (22 percent) groups (Table 9); the engraved sherds include 90 percent of the fine ware rims.

Table 9. Fine ware sherds in the mound deposits at the Mound Pond site.

\begin{tabular}{|c|c|c|c|}
\hline Decoration & Rim & Body & $\mathrm{N}$ \\
\hline $\begin{array}{l}\text { Opposed curvilinear engraved lines, } \\
\text { broad and fine, Holly Fine Engraved }\end{array}$ & - & 2 & 2 \\
\hline Curvilinear engraved lines & - & 4 & 4 \\
\hline $\begin{array}{l}\text { Curvilinear lines and excised zone, } \\
\text { Holly Fine Engraved }\end{array}$ & 1 & - & 1 \\
\hline Single curvilinear engraved line & - & 1 & 1 \\
\hline Diagonal engraved lines & 1 & - & 1 \\
\hline Horizontal engraved line & 1 & 1 & 2 \\
\hline $\begin{array}{l}\text { Horizontal engraved lines, fine, } \\
\text { Hickory Fine Engraved }\end{array}$ & 2 & - & 2 \\
\hline Horizontal engraved lines, CB & - & 1 & 1 \\
\hline $\begin{array}{l}\text { Horizontal and curvilinear engraved } \\
\text { lines, fine }\end{array}$ & 1 & - & 1 \\
\hline Horizontal and diagonal engraved lines & 1 & - & 1 \\
\hline $\begin{array}{l}\text { Horizontal and diagonal engraved } \\
\text { lines, excised triangle, Holly } \\
\text { Fine Engraved }\end{array}$ & - & 1 & 1 \\
\hline $\begin{array}{l}\text { Horizontal and diagonal hatched } \\
\text { engraved lines }\end{array}$ & 1 & - & 1 \\
\hline
\end{tabular}


Table 9. Fine ware sherds in the mound deposits at the Mound Pond site, cont.

\begin{tabular}{|c|c|c|c|}
\hline Decoration & Rim & Body & $\mathrm{N}$ \\
\hline $\begin{array}{l}\text { Horizontal, diagonal, and curvilinear } \\
\text { engraved lines, fine }\end{array}$ & 1 & - & 1 \\
\hline Parallel engraved lines & - & 2 & 2 \\
\hline Parallel engraved lines, fine & - & 1 & 1 \\
\hline $\begin{array}{l}\text { Parallel and diagonal opposed } \\
\text { engraved lines }\end{array}$ & - & 1 & 1 \\
\hline Straight engraved line & - & 5 & 5 \\
\hline Subtotal, Engraved & 9 & 19 & 28 \\
\hline brown slipped, ext. surface & - & 1 & 1 \\
\hline red slipped, ext. surface & 1 & 2 & 3 \\
\hline red slipped, ext. surface, Bottle & - & 4 & 4 \\
\hline Totals & 10 & 26 & 36 \\
\hline
\end{tabular}

$\mathrm{CB}=$ carinated bowl

The engraved sherds are from a mix of fine ware vessels that feature curvilinear lines, horizontal lines, and diagonal lines on the rim panels, either as the sole elements or in combination with each other (Figure 25b-c; see Table 9); 32 percent have curvilinear lines, while the remainder have straight or geometric elements. Six of the sherds are from Holly Fine Engraved vessels, with fine lines, and three other sherds with simple sets of horizontal engraved lines are from Hickory Engraved vessels. One rim sherd has a set of three horizontal engraved lines as well as a diagonal engraved zone filled with hatched lines (Figure 25d); this set of decorative elements is common in both Early and Middle Caddo period contexts in East Texas and along the Red River in Northwestern Louisiana.

The slipped sherds, both brown and red in color (see Figure 25a), are from bowls, carinated bowls, and bottles. The one red-slipped rim indicates that vessels decorated only with a red slip are present in the mound deposit decorated sherd assemblage.

Sherds from incised vessels are well-represented in the Mound Pond mound decorated sherd assemblage, accounting for 61 percent of all the sherds (see Table 8) and 51 percent of the decorated rim sherds (Table 10). Straight, horizontal, and diagonal incised lines are by far the most common decorative elements and motifs in the incised vessels, and only 0.4 percent of the incised sherds in the mound deposit have curvilinear lines. More than 73 percent of the incised rims are from vessels with horizontal incised lines (Figures 26a-c and 27a, c); another 15 percent have diagonal incised lines (Figure 28a); 7 percent have horizontal and diagonal lines (Figures 27b and 29c); 2 percent have vertical incised lines; and 2 percent are from Crockett Curvilinear Incised vessels (see Figure 25e) with diagonal incised scroll lines and curvilinear hatched scroll fill zones (see Suhm and Jelks 1962:Plate 17b, f-g, m; Webb and McKinney 1975:Figure 10a). 


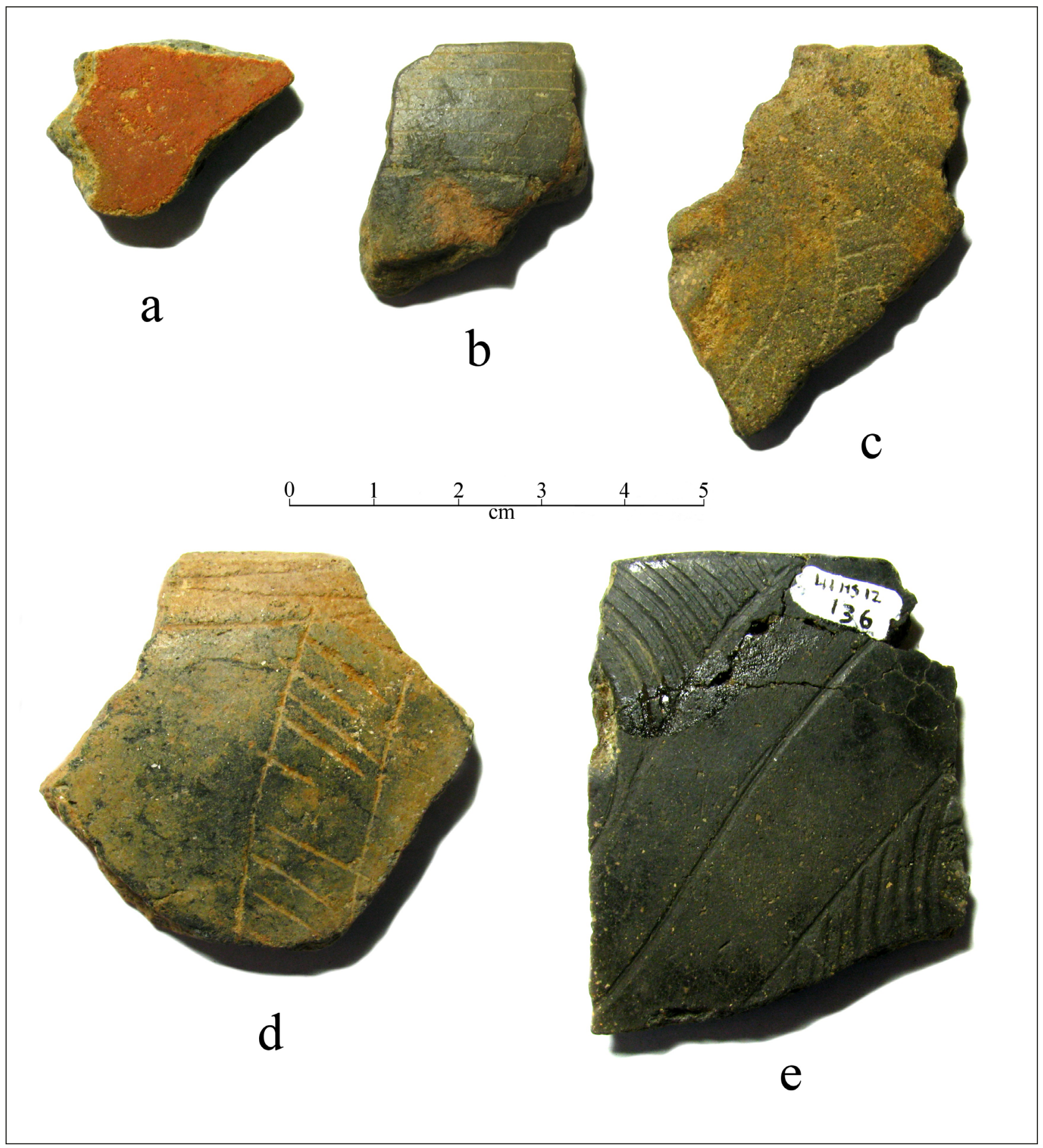

Figure 25. Red-slipped, engraved, and a finely-made Crockett Curvilinear Incised rim sherd: a, exterior red-slipped; b-c, Holly Fine Engraved; d, horizontal and hatched engraved diagonal zone rim; e, Crockett Curvilinear Incised rim sherd. Provenience: a, no provenience; b-c, N100 E108, lv. 2; d, N100 E102, 20-35 cm bs; e, N100 E112, 138-150 cm bs. 
Table 10. Incised sherds in mound deposits at the Mound Pond site.

\begin{tabular}{|c|c|c|c|}
\hline Decoration & Rim & Body & $\mathrm{N}$ \\
\hline Cross-hatched incised lines & - & 3 & 3 \\
\hline Curvilinear incised line & - & 1 & 1 \\
\hline Diagonal incised lines & 6 & 2 & 8 \\
\hline Diagonal opposed incised lines & - & 15 & 15 \\
\hline $\begin{array}{l}\text { Diagonal incised lines and curvilinear } \\
\text { hatched zones, Crockett } \\
\text { Curvilinear Incised }\end{array}$ & 1 & - & 1 \\
\hline Horizontal incised lines & 13 & 2 & 15 \\
\hline Horizontal incised lines, overhanging & 7 & 2 & 9 \\
\hline Horizontal incised lines, closely-spaced & 3 & 1 & 4 \\
\hline $\begin{array}{l}\text { Horizontal incised lines, closely- } \\
\text { spaced, overhanging }\end{array}$ & 2 & - & 2 \\
\hline Horizontal incised lines, widely-spaced & 2 & - & 2 \\
\hline $\begin{array}{l}\text { Horizontal incised lines, widely- } \\
\text { spaced, overhanging }\end{array}$ & - & 2 & 2 \\
\hline Horizontal incised line. mid-rim & 1 & - & 1 \\
\hline $\begin{array}{l}\text { Horizontal incised lines and lower } \\
\text { incised triangles }\end{array}$ & - & 1 & 1 \\
\hline $\begin{array}{l}\text { Horizontal incised lines, vertical } \\
\text { incised lines on body }\end{array}$ & 1 & - & 1 \\
\hline Horizontal incised line, int. surface & 1 & - & 1 \\
\hline Horizontal and cross-hatched incised lines & - & 1 & 1 \\
\hline Horizontal and diagonal incised lines & 1 & - & 1 \\
\hline $\begin{array}{l}\text { Horizontal and diagonal incised lines, } \\
\text { carinated bowl }\end{array}$ & - & 2 & 2 \\
\hline $\begin{array}{l}\text { Horizontal and diagonal incised lines, } \\
\text { closely-spaced }\end{array}$ & - & 1 & 1 \\
\hline $\begin{array}{l}\text { Horizontal and diagonal incised, excised } \\
\text { triangle, cf. Holly elements }\end{array}$ & 1 & - & 1 \\
\hline $\begin{array}{l}\text { Panels of horizontal and diagonal } \\
\text { incised lines; diagonal incised on body }\end{array}$ & 1 & - & 1 \\
\hline Opposed incised lines & - & 11 & 11 \\
\hline Closely-spaced parallel incised lines & - & 22 & 22 \\
\hline $\begin{array}{l}\text { Closely-spaced parallel incised lines, } \\
\text { overhanging }\end{array}$ & - & 3 & 3 \\
\hline Parallel incised lines & - & 75 & 75 \\
\hline
\end{tabular}


Table 10. Incised sherds in mound deposits at the Mound Pond site, cont.

\begin{tabular}{lccc}
\hline Decoration & Rim & Body & N \\
\hline Parallel incised lines, overhanging & - & 8 & 8 \\
Parallel and cross-hatched incised lines & - & 1 & 1 \\
Parallel and diagonal incised lines & - & 9 & 9 \\
Parallel and diagonal incised lines, & - & 1 & 1 \\
$\quad$ Crockett Curvilinear Incised & - & 41 & 31 \\
Straight incised line & - & 3 & 1 \\
Straight incised line, overhanging & - & 1 & 2 \\
Vertical incised lines & - & 2 & 2 \\
Vertical incised and diagonal opposed & & 1 & \\
incised lines & & & \\
$\quad$ diagonal opposed lines, Dunkin Incised & 1 & 211 & 252 \\
\hline Totals & 41 & & \\
\hline
\end{tabular}

Of the incised sherds from the mound deposits whose orientation is reasonably certain $(n=78)$, almost half of them are from vessels with multiple horizontal incised lines. Approximately 34 percent of these have overhanging lines, either closely-spaced (Coles Creek Incised, var. Mott) or widely-spaced (Coles Creek Incised, var. Coles Creek). Overall, of the 190 incised sherds that have or are presumed to have horizontal incised decorations, only 14 percent have overhanging lines; in the sub-mound midden deposits, 60 percent of the horizontal incised sherds have overhanging lines. These may be from both Coles Creek Incised and Davis Incised vessels.

The diagonal and diagonal opposed incised sherds account for 9.1 percent of the incised sherds and 14.6 percent of the incised rims. These sherds appear to be from Dunkin Incised vessels (see Suhm and Jelks 1962:Plate 19b, g-h). The sherds with vertical incised lines or vertical panels (see Figure 29b) may also be from Dunkin Incised vessels. So too may be the three cross-hatched incised body sherds and one body sherd with horizontal and cross-hatched incised lines (see Suhm and Jelks 1962:Plate 19i). One unique incised rim sherd has both horizontal and diagonal-filled panels (see Figure 29c), while another rim has Holly Fine Engraved style horizontal and diagonal sets of lines (see Suhm and Jelks 1962:Plate 40a), but executed as fine incised lines and an associated hatched triangle rather than engraved lines and an excised triangle element.

Punctated sherds comprise 11.9 percent of the decorated sherds in the mound deposits. These sherds primarily have fingernail punctated elements (Table 11 and Figure 30), but there are also tool punctated sherds (22 percent of the punctated sherds), including triangular-shaped punctations (Figure 31a), sherds with linear punctations ( 2 percent), and three with closely-spaced vertical rows of small V-shaped punctations (Figure 31e). The V-shaped punctated rows resemble Chevalier Stamped, var. Chevalier (Brown 1998:34; Phillips 1970:65). 


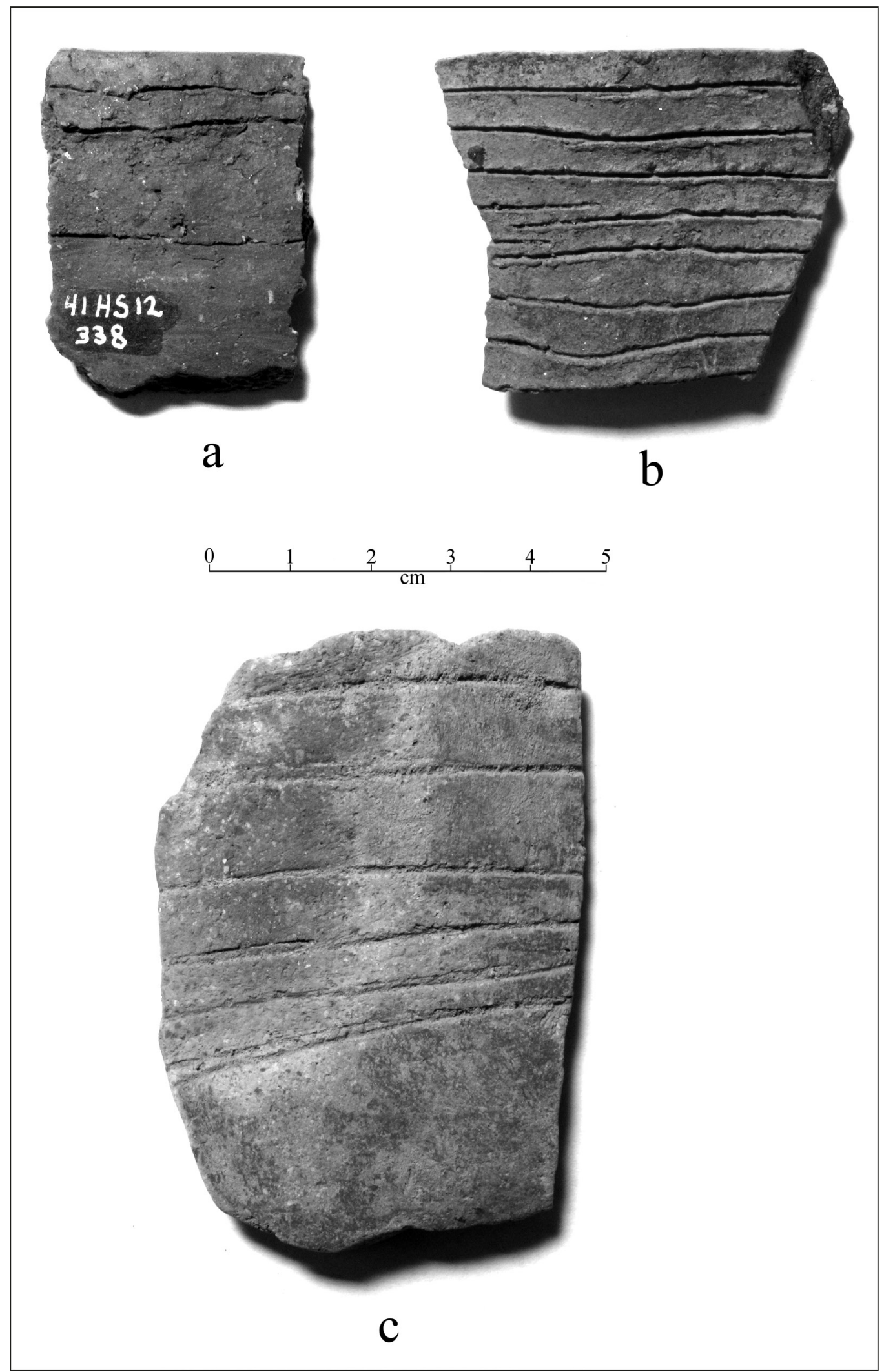

Figure 26. Horizontal incised sherds from the midden and mound deposits. Provenience: a, N97 E111, 0-5 cm in midden; b, N100 E102, 20-35 cm bs; c, N100 E104, 20-35 cm bs. 


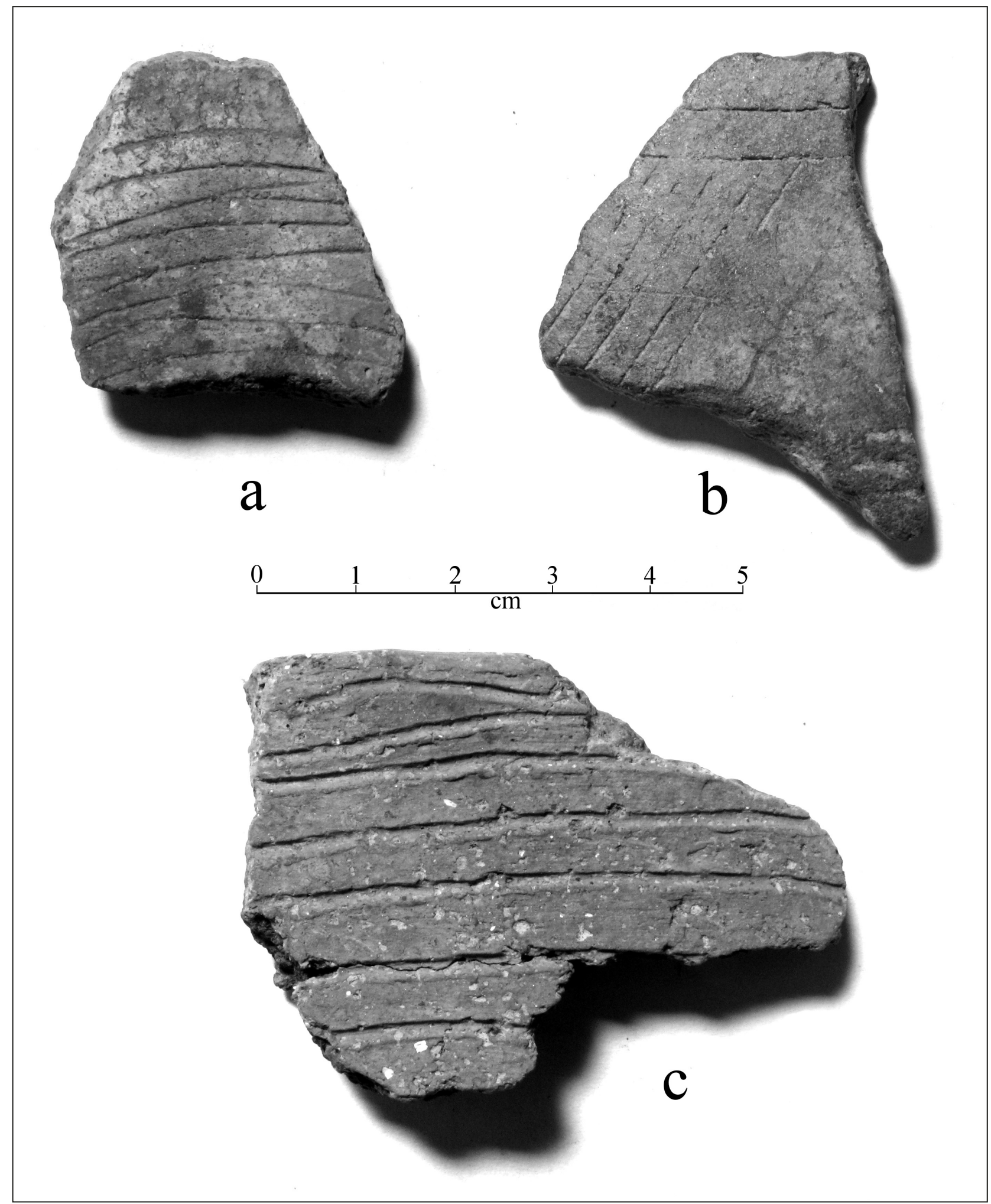

Figure 27. Horizontal, parallel, and parallel-diagonal incised sherds from the mound deposits. Provenience: a, N100 E100, 50-65 cm bs; b, N100 E108, 0-20 cm bs; c, N100 E102, 65-80 cm bs. 


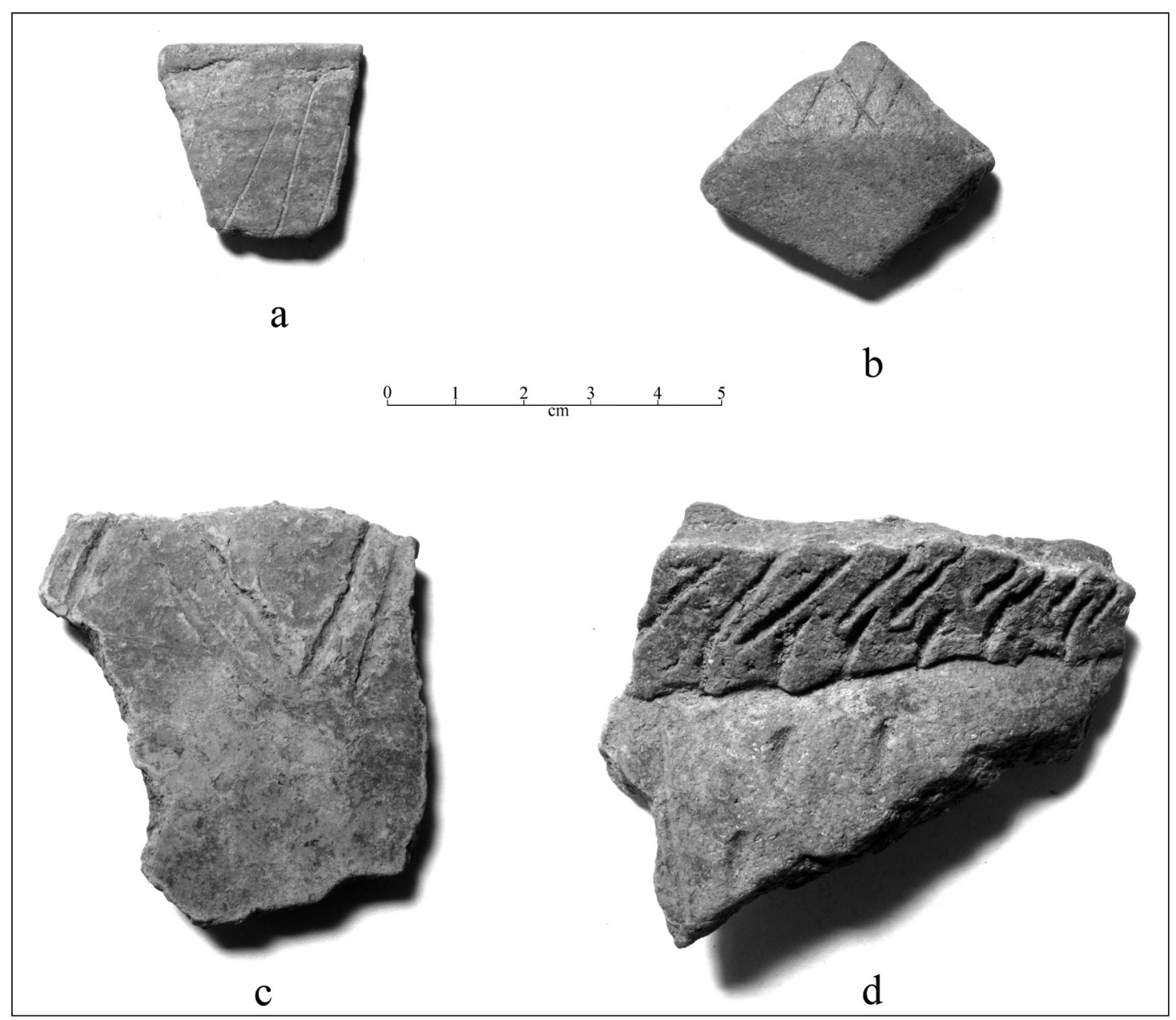

Figure 28. Incised and Incised-punctated sherds from the mound and midden deposits; a, diagonal incised; b, cross-hatched incised; $c$, chevron incised; d, diagonal incised on collared rim, and fingernail punctated rows. Provenience: a, N100 E108, 0-20 cm bs; b, N100 E106, level 1; c, N100 E108, 0-5 cm in midden; d, N100 E102, 65-80 cm bs.

The five Hollyknowe Ridge Pinched body sherds comprise 1.2 percent of the decorated sherds in the mound deposit assemblage (see Tables 8 and 11). This is slightly less than the percentage of pinchedridged sherds in the sub-mound midden deposits. One rim in the mound deposit sherd assemblage has horizontal incised lines with a row of pinched ridges under the vessel lip and above the incised lines (see Table 12, below). It may be stylistically related to Hollyknowe Ridge Pinched.

In addition to the few Coles Creek Incised sherds with incised elements that can only be identified to a specific variety (see above), two Coles Creek Incised, var. Coles Creek body sherds are present in the mound deposits that have horizontal incised lines above a row of impressed triangles (Table 12). These represent 0.5 percent of the decorated sherds in this component, compared to 5.3 percent of the decorated sherds in the sub-mound midden assemblage. The frequency of the impressed triangle as a decorative element may thus have chronological significance because it is more common in the midden deposits buried by later mound deposits than it is in the overlying mound deposits. 


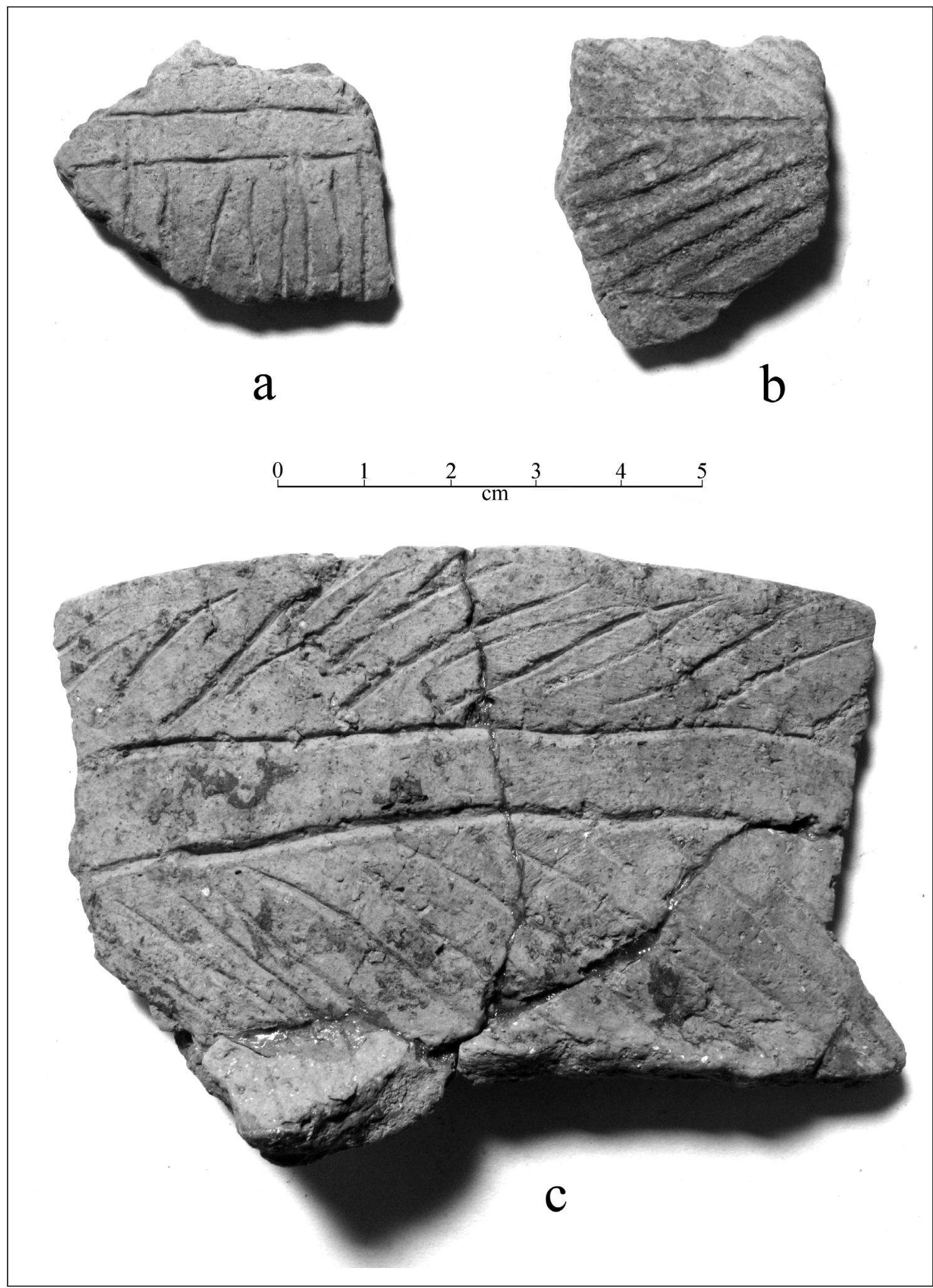

Figure 29. Other incised decorative elements on sherds from the mound deposits: a, parallel and diagonal incised lines; $b$, panels filled with incised lines; $c$, diagonal incised rim panels and horizontal incised lines; diagonal incised body. Provenience: a, N100 E104, 35-50 cm bs; b, N100 E102, 20-35 cm bs; c, N100 E104, 20-35 cm bs. 
Table 11. Punctated, pinched, and punctated-pinched sherds in the mound deposits at the Mound Pond site.

\begin{tabular}{lccc} 
Decoration & Rim & Body & N \\
\hline Fingernail punctated, free & - & 6 & 6 \\
Fingernail punctate, single & 1 & 5 & 6 \\
Fingernail punctated row or rows & - & 22 & 1 \\
Linear punctate row & - & - & 1 \\
Tool punctated row under vessel lip & 1 & 5 & 8 \\
Tool punctated rows & 3 & 1 & 2 \\
Tool punctate, single & 1 & 3 & 3 \\
Vertical rows of small punctations & - & 43 & 49 \\
Subtotal, Punctated & 6 & 1 & 1 \\
Curvilinear pinched ridges & - & 3 & 3 \\
Parallel pinched ridges & - & & 1 \\
Vertical rows of small punctations on & - & 1 & 54 \\
pinched ridges & & 48 & \\
\hline Totals & 6 & & \\
\hline
\end{tabular}

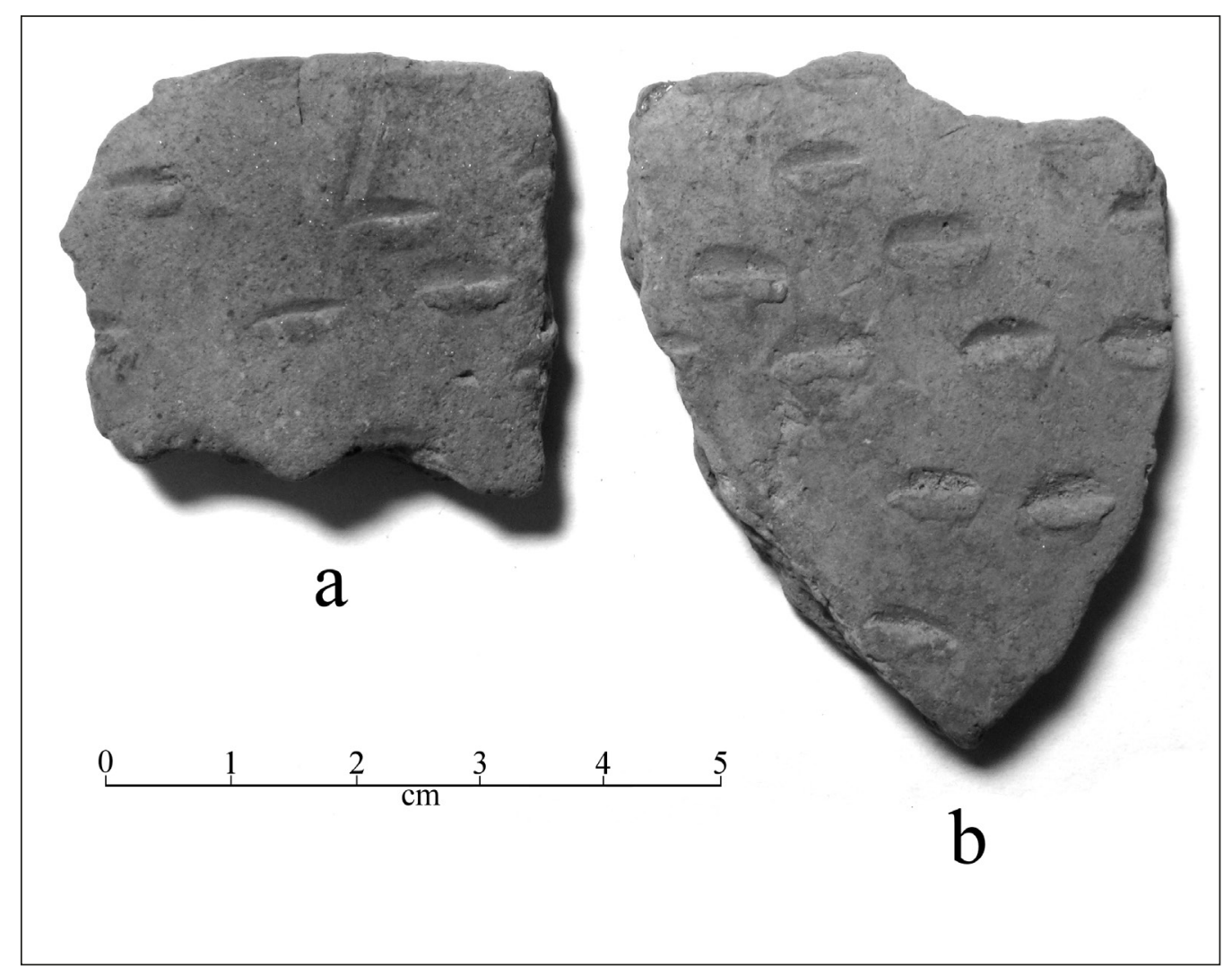

Figure 30. Fingernail punctated body sherds. Provenience: a, N100 E104, 35-50 cm bs; b, N100 E106, level 2. 


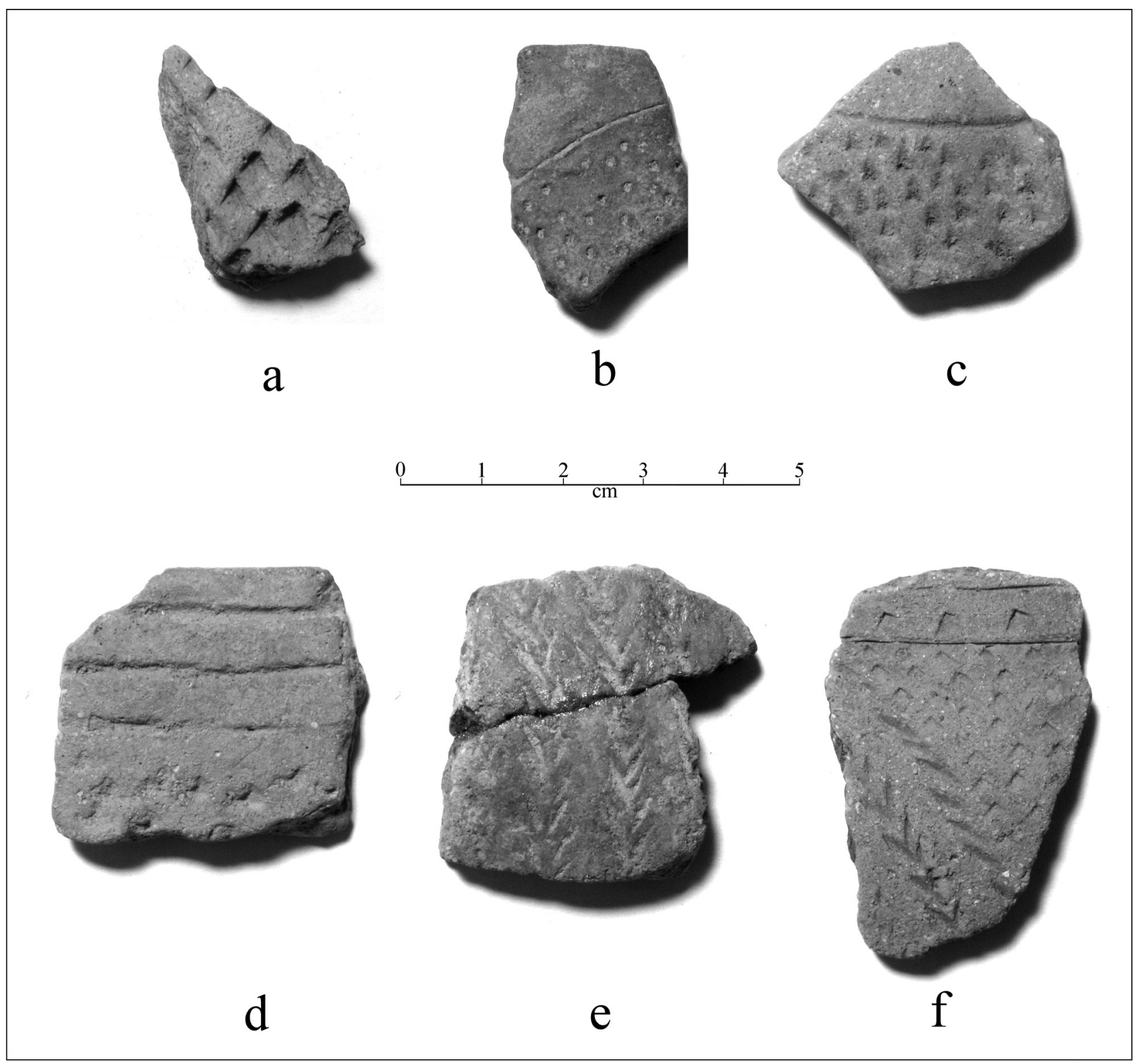

Figure 31. Punctated and incised-punctated sherds from the mound deposits: a, tool punctated; b-c, curvilinear incised-punctated; d, horizontal incised lines over tool punctated rows; e, V-shaped punctated body sherds; f, V-shaped punctations and parallel incised lines. Provenience: a, N100 E100, 20-35 cm bs; b, N100 E102, 35-50 cm bs; c-d, N100 E106, level 2; e, N100 E108, 80-97 cm bs; f, N100 E110, 110-130 cm bs.

The incised-punctated sherds in the mound deposit sherd assemblage comprise 15.5 percent of the assemblage as a whole, and they are a significant aspects of the sherds from this component at the Mound Pond site. Moreover, 27 percent of the decorated rims in this assemblage are from incised-punctated vessels. About 5 percent of the incised-punctated sherds feature circular or curvilinear zones filled with tool or cane punctations (see Figure 31b-c), and these sherds are likely from Crockett Curvilinear Incised vessels (see Suhm and Jelks 1962:Plate 17). Another 25 percent have incised panels filled with punctations. The remainder of the incised-punctated sherds in the mound deposits have horizontal, parallel-straight, diagonal, and vertical incised lines with horizontal or vertical rows of punctations (Figures 32a-e and 
Table 12. Incised-impressed triangles, incised-pinched, incised-punctated, and band punctated sherds in the mound deposits at the Mound Pond site.

\begin{tabular}{|c|c|c|c|}
\hline Decoration & Rim & Body & $\mathrm{N}$ \\
\hline $\begin{array}{l}\text { Horizontal incised lines and impressed } \\
\text { triangles, Coles Creek Incised }\end{array}$ & - & 2 & 2 \\
\hline $\begin{array}{l}\text { Horizontal incised lines, with pinched } \\
\text { row under lip }\end{array}$ & 1 & - & 1 \\
\hline $\begin{array}{l}\text { Circular incised zone filled with tool } \\
\text { punctates }\end{array}$ & - & 1 & 1 \\
\hline $\begin{array}{l}\text { Circular incised zone filled with small } \\
\text { circular punctates }\end{array}$ & 1 & - & 1 \\
\hline $\begin{array}{l}\text { Incised chevron with vertical row of } \\
\text { tool punctates }\end{array}$ & - & 4 & 4 \\
\hline $\begin{array}{l}\text { Curvilinear incised zone filled with } \\
\text { circular punctations }\end{array}$ & - & 1 & 1 \\
\hline $\begin{array}{l}\text { Curvilinear incised zone adjacent to } \\
\text { tool punctates }\end{array}$ & - & 1 & 1 \\
\hline $\begin{array}{l}\text { Curvilinear and diagonal incised } \\
\text { zones filled with tool punctates, CB }\end{array}$ & - & 1 & 1 \\
\hline $\begin{array}{l}\text { Diagonal incised lines and fingernail } \\
\text { punctated row at rim-body juncture, } \\
\text { collared rim }\end{array}$ & 1 & - & 1 \\
\hline $\begin{array}{l}\text { Diagonal incised lines, with finger- } \\
\text { nail punctated row under lip }\end{array}$ & 1 & - & 1 \\
\hline $\begin{array}{l}\text { Diagonal incised line above finger- } \\
\text { nail punctated row }\end{array}$ & - & 1 & 1 \\
\hline $\begin{array}{l}\text { Diagonal incised with tool punctated } \\
\text { row under vessel lip }\end{array}$ & 8 & - & 8 \\
\hline $\begin{array}{l}\text { Diagonal incised with tool punctated } \\
\text { row at lip; lip notched }\end{array}$ & 2 & - & 2 \\
\hline $\begin{array}{l}\text { Diagonal incised lines and tool } \\
\text { punctated row }\end{array}$ & - & 5 & 5 \\
\hline $\begin{array}{l}\text { Diagonal opposed incised lines with } \\
\text { tool punctated row and diagonal tool } \\
\text { punctated row through incised lines }\end{array}$ & - & 1 & 1 \\
\hline $\begin{array}{l}\text { Diagonal opposed incised lines and } \\
\text { tool punctates in triangular zone }\end{array}$ & - & 1 & 1 \\
\hline $\begin{array}{l}\text { Diagonal opposed incised panels, with } \\
\text { tool punctated rows between panels }\end{array}$ & 1 & 1 & 2 \\
\hline
\end{tabular}


Table 12. Incised-impressed triangles, incised-pinched, incised-punctated, and band punctated sherds in the mound deposits at the Mound Pond site, cont.

\begin{tabular}{|c|c|c|c|}
\hline Decoration & Rim & Body & $\mathrm{N}$ \\
\hline $\begin{array}{l}\text { Horizontal incised lines above circular } \\
\text { punctated rows }\end{array}$ & 1 & - & 1 \\
\hline $\begin{array}{l}\text { Horizontal incised lines, tool punctated } \\
\text { row under lip }\end{array}$ & 2 & - & 2 \\
\hline $\begin{array}{l}\text { Horizontal incised lines adjacent to } \\
\text { tool punctated row }\end{array}$ & - & 3 & 3 \\
\hline $\begin{array}{l}\text { Horizontal incised lines above row } \\
\text { of tool punctates }\end{array}$ & - & 1 & 1 \\
\hline $\begin{array}{l}\text { Horizontal incised lines between } \\
\text { rows of tool punctations }\end{array}$ & 1 & - & 1 \\
\hline $\begin{array}{l}\text { Horizontal incised line below tool } \\
\text { punctated rows }\end{array}$ & 1 & - & 1 \\
\hline $\begin{array}{l}\text { Horizontal incised line below collar, } \\
\text { tool punctated row on collar }\end{array}$ & 1 & - & 1 \\
\hline $\begin{array}{l}\text { Horizontal and diagonal incised lines } \\
\text { and triangular zone of cane punctates }\end{array}$ & - & 1 & 1 \\
\hline Incised triangle filled with tool punctations & - & 1 & 1 \\
\hline $\begin{array}{l}\text { Parallel incised lines adjacent to finger- } \\
\text { nail punctated zone }\end{array}$ & - & 5 & 5 \\
\hline Parallel incised lines and tool punctated row & - & 1 & 1 \\
\hline $\begin{array}{l}\text { Parallel incised lines adjacent to tool } \\
\text { punctated zone }\end{array}$ & - & 2 & 2 \\
\hline $\begin{array}{l}\text { Straight incised line adjacent to single } \\
\text { tool punctate }\end{array}$ & - & 1 & 1 \\
\hline $\begin{array}{l}\text { Straight incised line adjacent to rows } \\
\text { of tool punctates }\end{array}$ & - & 3 & 3 \\
\hline $\begin{array}{l}\text { Straight incised line adjacent to finger- } \\
\text { nail punctated rows }\end{array}$ & - & 2 & 2 \\
\hline $\begin{array}{l}\text { Straight incised line adjacent to finger- } \\
\text { nail punctated zone }\end{array}$ & - & 2 & 2 \\
\hline $\begin{array}{l}\text { Vertical incised lines and fingernail } \\
\text { punctated row on same line; lip } \\
\text { notched }\end{array}$ & 1 & - & 1 \\
\hline $\begin{array}{l}\text { Vertical incised lines and vertical tool } \\
\text { punctated row through lines }\end{array}$ & - & 1 & 1 \\
\hline $\begin{array}{l}\text { Vertical incised lines above tool } \\
\text { punctated row or rows }\end{array}$ & - & 2 & 2 \\
\hline
\end{tabular}


Table 12. Incised-impressed triangles, incised-pinched, incised-punctated, and band punctated sherds in the mound deposits at the Mound Pond site, cont.

\begin{tabular}{lccc}
\hline Decoration & Rim & Body & N \\
\hline Subtotal, Incised-Punctated & 22 & 44 & 66 \\
$\begin{array}{l}\text { Horizontal incised lines and band of } \\
\text { impressed triangles, band punctated } \\
\begin{array}{l}\text { Horizontal incised band filled with tool } \\
\text { punctates, band punctated }\end{array}\end{array}$ & 1 & - & 1 \\
$\begin{array}{l}\text { Horizontal incised band filled with } \\
\text { tool punctates; horizontal and } \\
\text { diagonal rows of tool punctates }\end{array}$ & - & 1 & 1 \\
$\begin{array}{l}\text { Parallel incised lines with tool } \\
\text { punctated row between, band punctated }\end{array}$ & - & 1 & 1 \\
Subtotal, Band Punctated & - & 1 & 1 \\
\hline \begin{tabular}{l} 
Totals \\
\hline
\end{tabular} & 1 & 3 & 4 \\
\hline
\end{tabular}

$\mathrm{CB}=$ carinated bowl

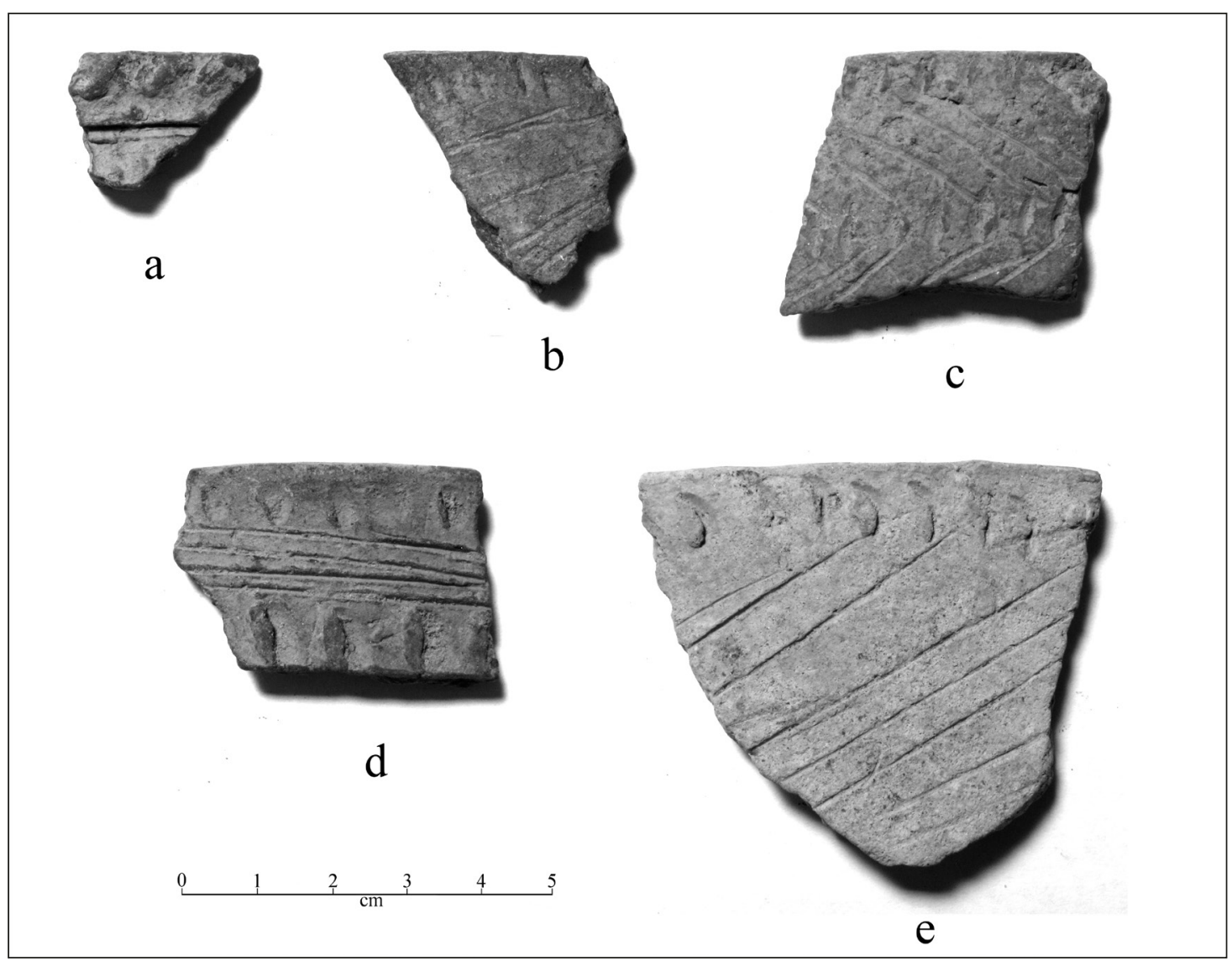

Figure 32. Incised-punctated rim sherds. Provenience: a-b, no provenience; c, N100 E108, 0-20 cm bs; d, N100 E108, 80-97 cm bs; e, N100 E102, 20-35 cm bs. 


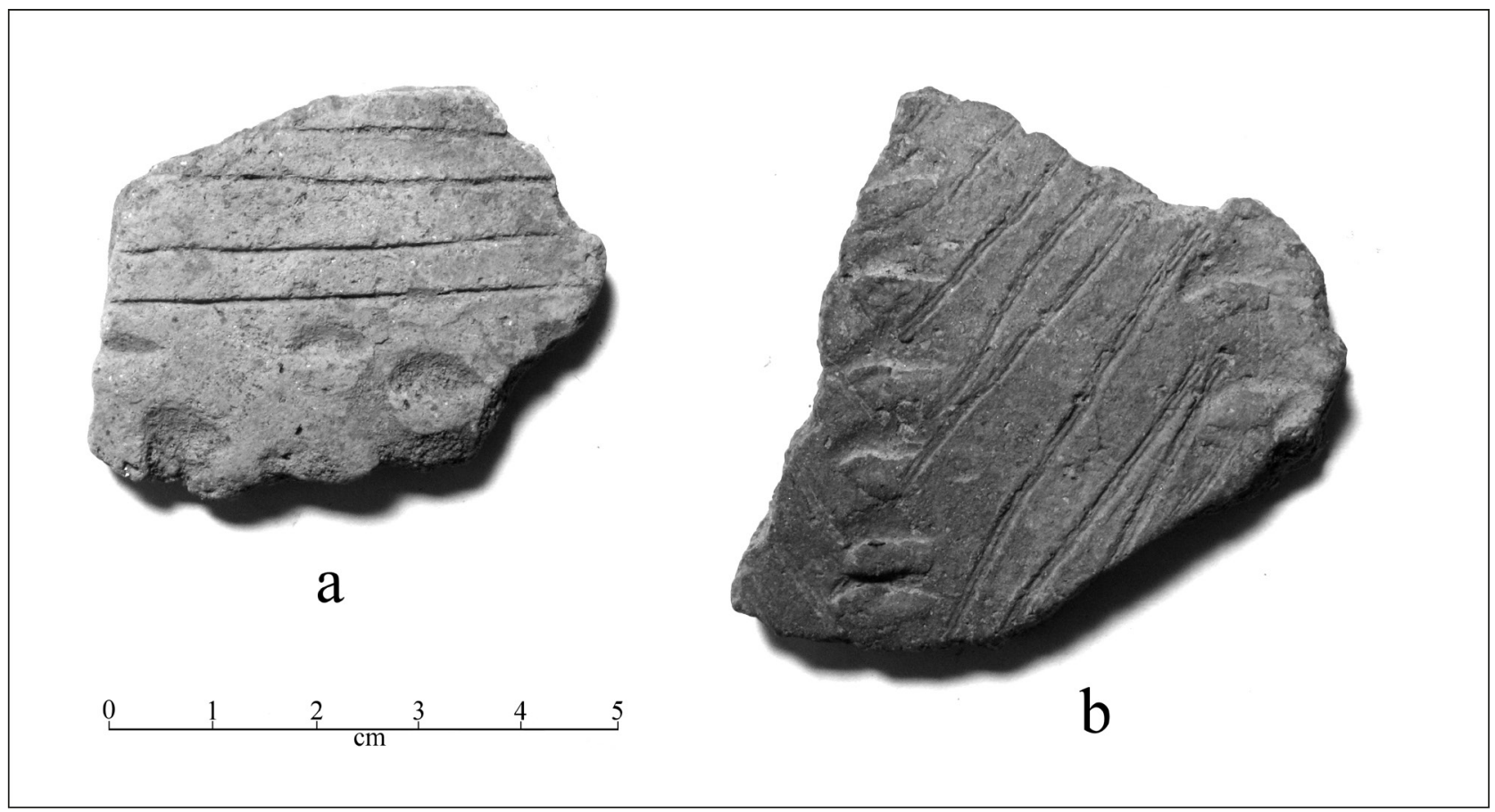

Figure 33. Incised-punctated body sherds from the mound deposits. Provenience: a-b, N100 E106, level 1.

$33 b$ ), incised triangles filled with punctations, or rows of punctations adjacent to sets of parallel or horizontal incised lines (Figure 33a).

Approximately 72 percent of the incised-punctated sherds in the mound deposits have tool punctations, followed by fingernail punctations ( 20 percent), large circular punctations ( 5 percent, see Figure $33 \mathrm{a})$, and cane punctations ( 2 percent). The most distinctive rims have a row of punctations under the vessel lip (see Figure 32a-b, e), and most commonly sets of diagonal incised lines pitched either to the left or the right. Others have rows of punctations under the vessel lip along with panels of horizontal or diagonal incised lines separated by a second punctated row at mid-rim (see Figure 32c-d). Punctations on these incised-punctated sherds tend to occur in a single row under the vessel lip, or a single row at the rim-body juncture. Vertical rows of punctations are associated with incised chevrons (see Figure 33b).

Two incised-punctated rim sherds in the mound deposits are lip notched (see Table 12). One has diagonal incised lines as the main decorative motif, and the punctated row has been placed at the lip instead of under the vessel lip. The other lip notched rim has vertical incised lines and fingernail punctations on the same line on the rim itself, with the lip itself being notched.

Four of the incised-punctated sherds in the mound deposit decorated sherd assemblage are classified as band-punctated. They have parallel or horizontal incised lines with bands of impressed triangles (Figure 34) or single rows of tool punctations between the incised lines. Regarding the former, Girard (2009a:28) has made the suggestion that these sherds with impressed punctations between incised lines are a regional variant of Coles Creek Incised, var. Coles Creek. The latter band punctated sherds warrant separation as a distinct kind of decorative element from those that have large impressed triangles, primarily because the large impressed triangles suggest a direct connection with the Coles Creek Incised or Weches Fingernail Impressed types. 


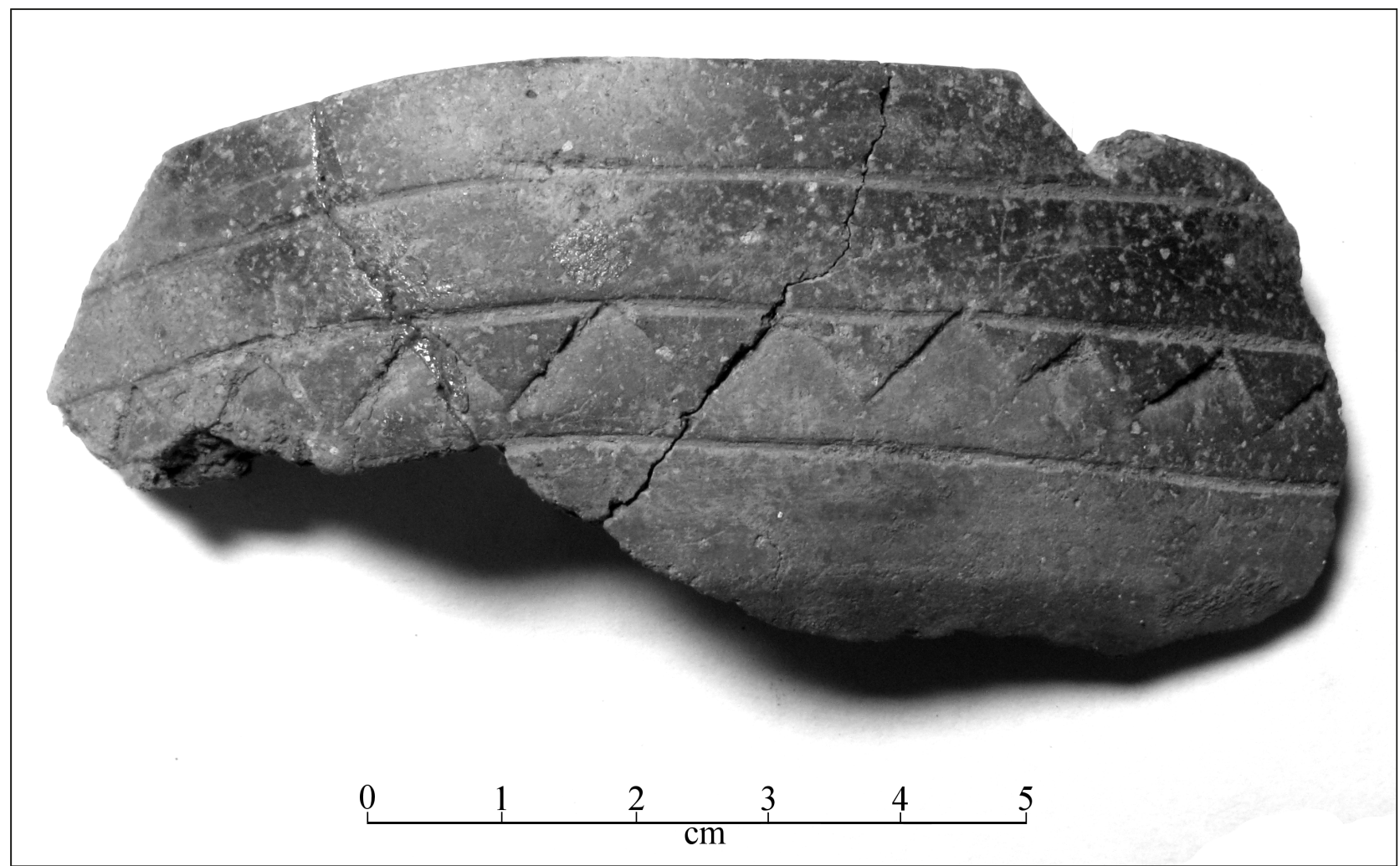

Figure 34. Band punctated rim sherd from the mound deposits. Provenience: N100 E108, 85-100 cm bs.

\section{Sub-mound Midden Deposits}

The decorated ceramic assemblage from the sub-mound midden deposits at the Mound Pond site is very distinctive as a group. Story (1990a:745) had commented some years ago that "a preliminary examination of the sherd collection indicates Coles Creek and early Caddoan styles both present with the Coles Creek material evidently being earlier of the two. Similarities to Mounds Plantation in northwestern Louisiana are strong." The sherds in the sub-midden deposits, as indicated by Story (1990a), are dominated by horizontal incised Coles Creek Incised types with overhanging lines; only one incised sherd had an incised lip line (Table 13). Some of the horizontal incised sherds could also be from Davis Incised vessels (Suhm and Jelks 1962:35 and Plate 18). It is likely that vessels of both types were made locally, based on chemical analysis of the paste from Coles Creek Incised vessel sherds found in East Texas (Walters and Perttula 2010:37 and Figure 3).

Table 13. Sub-mound midden decorated sherds.

$\begin{array}{llll}\text { Decoration } & \text { Rim } & \text { Body }\end{array}$

Curvilinear engraved line

Curvilinear and straight engraved lines

Straight engraved line

Horizontal incised lines

Horizontal incised line, mid-rim, Coles Creek Incised

$\begin{array}{lll}- & 1 & 1 \\ - & 1 & 1 \\ - & 3 & 3 \\ 5 & 1 & 6 \\ 1 & - & 1\end{array}$


Table 13. Sub-mound midden decorated sherds, cont.

\begin{tabular}{|c|c|c|c|}
\hline Decoration & $\operatorname{Rim}$ & Body & $\mathrm{N}$ \\
\hline $\begin{array}{l}\text { Horizontal incised line, mid-rim, } \\
\text { overhanging line, Coles Creek Incised }\end{array}$ & 5 & - & 5 \\
\hline $\begin{array}{l}\text { Horizontal incised lines, collared, } \\
\text { Coles Creek Incised }\end{array}$ & - & 1 & 1 \\
\hline $\begin{array}{l}\text { Horizontal incised lines, collared, } \\
\text { overhanging, Coles Creek Incised }\end{array}$ & 1 & - & 1 \\
\hline Horizontal incised lines, closely-spaced & 10 & 1 & 11 \\
\hline $\begin{array}{l}\text { Horizontal incised lines, closely- and } \\
\text { widely-spaced }\end{array}$ & 4 & - & 4 \\
\hline Horizontal incised lines, widely-spaced & 4 & 1 & 5 \\
\hline $\begin{array}{l}\text { Horizontal incised, widely-spaced, and } \\
\text { overhanging, Coles Creek Incised }\end{array}$ & 10 & 10 & 20 \\
\hline $\begin{array}{l}\text { Horizontal incised lines, widely-spaced } \\
\text { and overhanging; incised lip line, } \\
\text { Coles Creek Incised }\end{array}$ & 1 & - & 1 \\
\hline $\begin{array}{l}\text { Horizontal incised lines, overhanging } \\
\text { Coles Creek Incised }\end{array}$ & 4 & 13 & 17 \\
\hline $\begin{array}{l}\text { Horizontal incised lines and incised } \\
\text { pendant triangles, Coles Creek Incised }\end{array}$ & - & 2 & 2 \\
\hline Incised chevron & - & 2 & 2 \\
\hline Parallel incised lines & - & 12 & 12 \\
\hline Parallel incised lines, overhanging & - & 7 & 7 \\
\hline Parallel incised lines, closely-spaced & - & 2 & 2 \\
\hline $\begin{array}{l}\text { Parallel incised lines, closely-spaced, } \\
\text { overhanging }\end{array}$ & - & 7 & 7 \\
\hline Straight incised line & - & 8 & 8 \\
\hline Straight incised line, overhanging & - & 4 & 4 \\
\hline $\begin{array}{l}\text { Incised triangle filled with fingernail } \\
\text { punctations }\end{array}$ & - & 1 & 1 \\
\hline $\begin{array}{l}\text { Parallel incised lines above fingernail } \\
\text { punctated zone }\end{array}$ & - & 1 & 1 \\
\hline $\begin{array}{l}\text { Horizontal incised lines and impressed } \\
\text { triangles, Coles Creek Incised }\end{array}$ & - & 3 & 3 \\
\hline $\begin{array}{l}\text { Horizontal incised lines and impressed } \\
\text { triangles, overhanging lines, Coles } \\
\text { Creek Incised }\end{array}$ & - & 3 & 3 \\
\hline Impressed triangles, Coles Creek Incised & - & 1 & 1 \\
\hline
\end{tabular}


Table 13. Sub-mound midden decorated sherds, cont.

\begin{tabular}{lccc}
\hline Decoration & Rim & Body & N \\
\hline Parallel pinched ridges & - & 1 & 1 \\
Vertical pinched ridges & 1 & - & 1 \\
Fingernail punctated rows & - & 1 & 1 \\
\hline Totals & 46 & 87 & 133 \\
\hline
\end{tabular}

The horizontal incised sherds from the Mound Pond site account for 56 percent of the decorated sherd assemblage from the sub-mound midden deposits, but 98 percent of the incised rim sherds (see Table 13). Vessels with incised decorations are clearly the predominant decorative class, both among the utility wares as well as among the entire decorated sherd assemblage in this unique deposit. The majority of the incised sherds - especially the rim sherds - are from vessels with one to many horizontal incised lines on the rim of bowls (Figures 35-37). All of the incised sherds are probably from different varieties of post-A.D. 850-1000 Coles Creek Incised vessels (see Brown 1998; Girard 2014; Phillips 1970), including var. Coles Creek (but without a punctated row or impressed triangles below the horizontal lines, Figure 35a-b), var. Chase (Figure 36a) with its collared rim, var. Hardy, var. Mott (Figure 35b-c), and var. Blakely (Figure 37). Approximately 60 percent of the horizontal incised sherds have overhanging lines: the incised lines were made with "a flat ended tool held at an oblique angle to vessel wall" (Phillips 1970:72). Most of these have multiple and widely-spaced lines.

Those sherds that have closely spaced horizontal incised lines are probably from Coles Creek Incised, var. Mott (those with overhanging lines), or var. Hardy or var. Blakely (those varieties without overhanging lines) (Brown 1998:9). Almost all of the sherds with closely-spaced horizontal lines do not have overhanging lines. Those with widely-spaced horizontal incised lines that do have overhanging lines are sherds from Coles Creek Incised, var. Coles Creek vessels. Several sherds have both closely-spaced and widely-spaced horizontal incised lines (see Figure 27a), but no overhanging lines.

One Coles Creek Incised, var. Campbellsville rim sherd has widely-spaced horizontal incised lines and a single incised line on the lip. Another horizontal incised sherd has a set of incised pendant triangles below the bottom horizontal line; this incised element is likely a simulation of the row of impressed triangles found below the lowest horizontal incised line on Coles Creek Incised, var. Coles Creek vessels.

Other horizontal incised sherds $(n=6)$ have a single row of impressed triangles below the incised lines (Figure 38a-b), and one body sherd just has impressed triangles (see Table 13). These are from Coles Creek Incised, var. Coles Creek vessels. The row of large impressed-punctated triangles was "evidently made with a corner of the same flat-ended tool" (Phillips 1970:70) used to make the horizontal incised lines on the vessels.

A number of the incised sherds have straight or parallel sets of lines, and are likely from the lower rim and upper body area of horizontal incised vessels. They are almost equally divided between those with overhanging lines $(n=18)$ and those without $(n=22)$. These are most likely also from Coles Creek Incised vessels. One sherd has an incised chevron that may be from a Dunkin Incised vessel (see Figure 28c). It has a chevron-shaped set of opposed diagonal incised lines, perhaps from the lowermost part of the rim decoration (see Suhm and Jelks 1962:Plate 19f-g). 


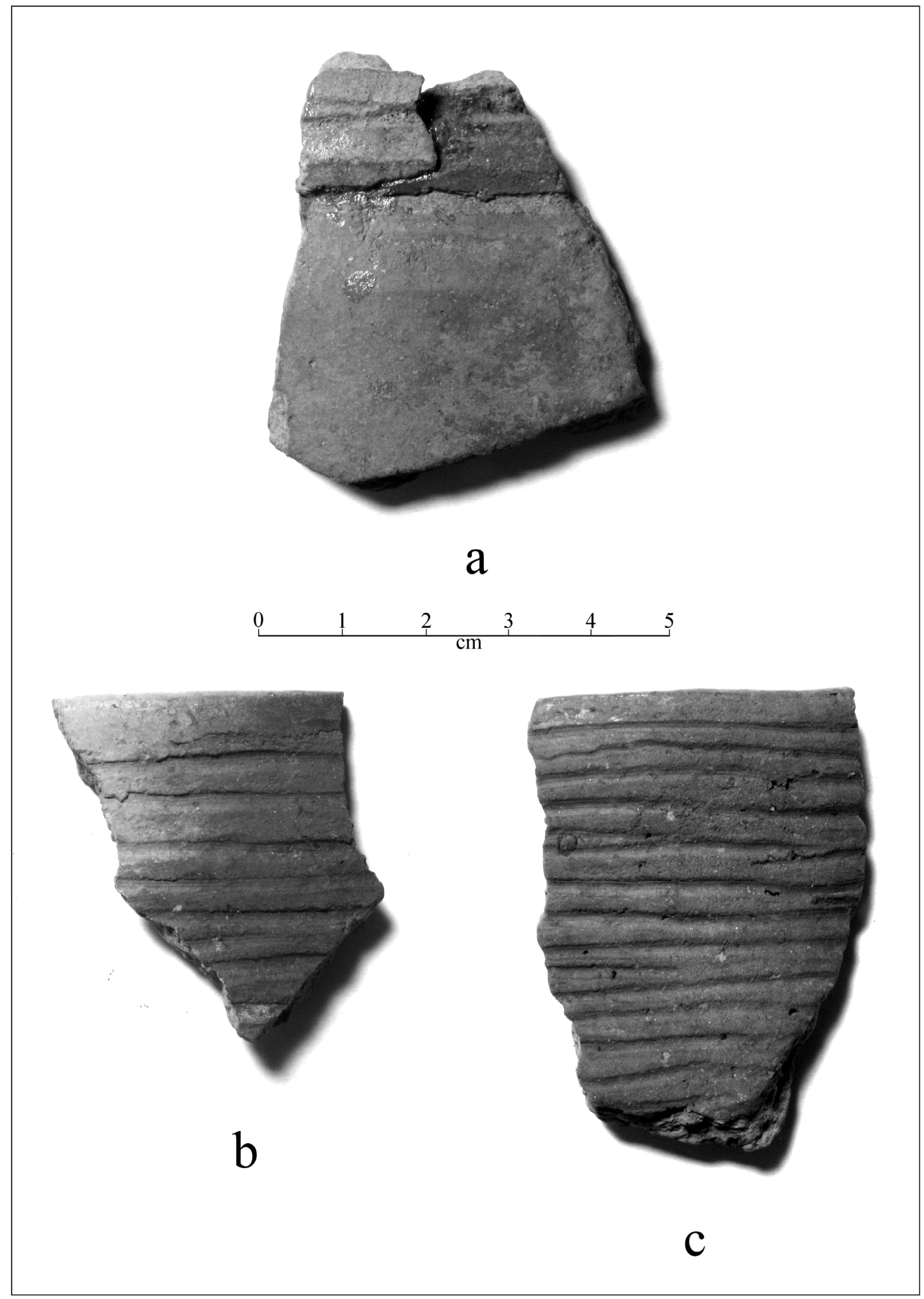

Figure 35. Coles Creek Incised sherds from the sub-mound midden deposits: a, Coles Creek Incised, var. Chase; b-c, Coles Creek Incised, var. Mott. Provenience: a, no provenience; b-c, N95 E115, 0-10 cm in midden. 


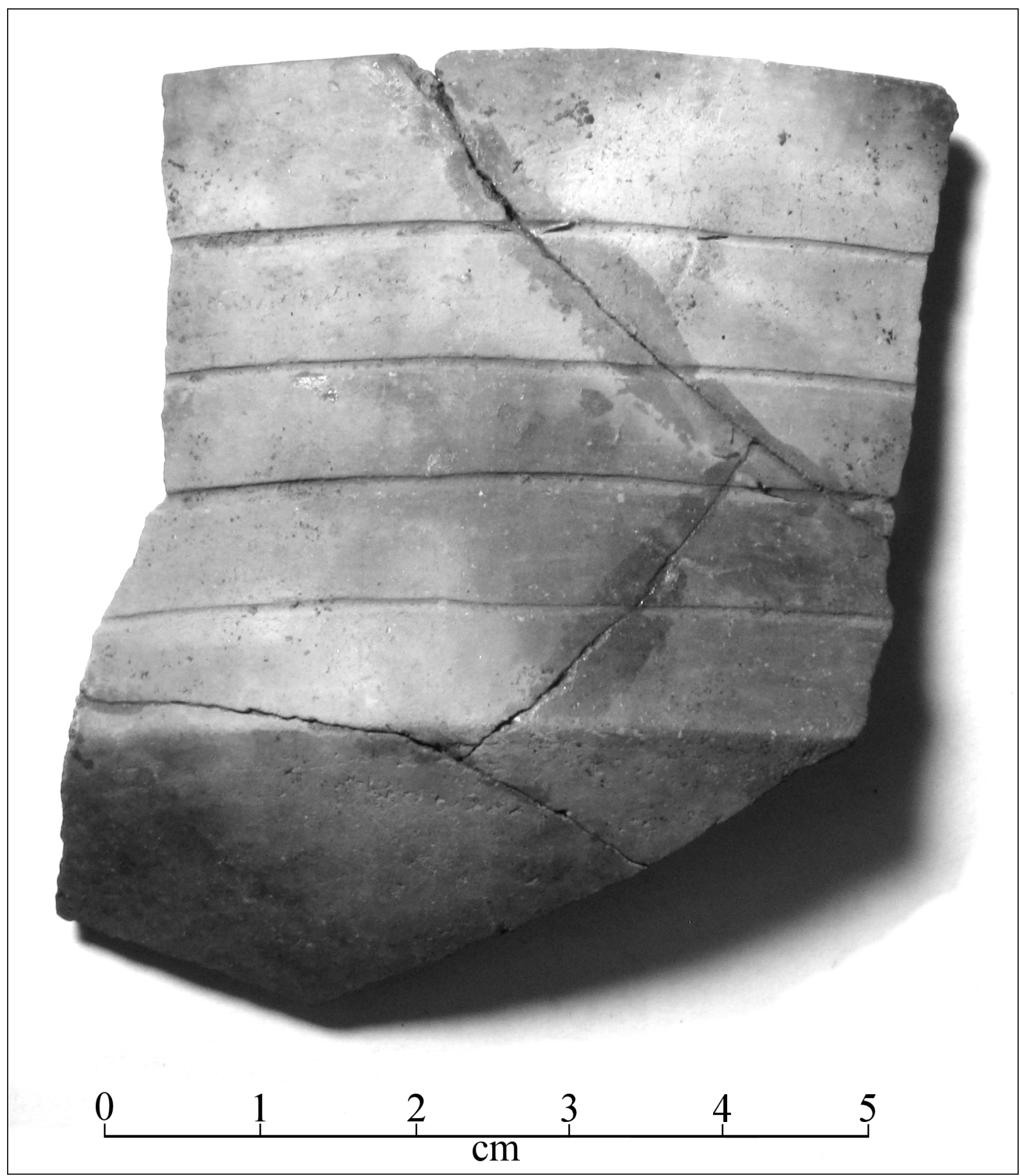

Figure 36. Coles Creek Incised, var. Blakely carinated bowl. Provenience: N100 E110, midden.

Two body sherds (1.5 percent of the decorated sherd assemblage) from the sub-mound midden deposits are from incised-punctated vessels. One has recognizable triangular incised zones filled with fingernail punctations, while the other has a set of parallel incised lines adjacent to a zone of unknown shape filled with fingernail punctations.

The pinched ridged sherds are from Hollyknowe Ridge Pinched vessels (see Phillips 1970:89), probably var. Hollyknowe (Brown 1998:28) or a locally produced example of the type. They comprise 


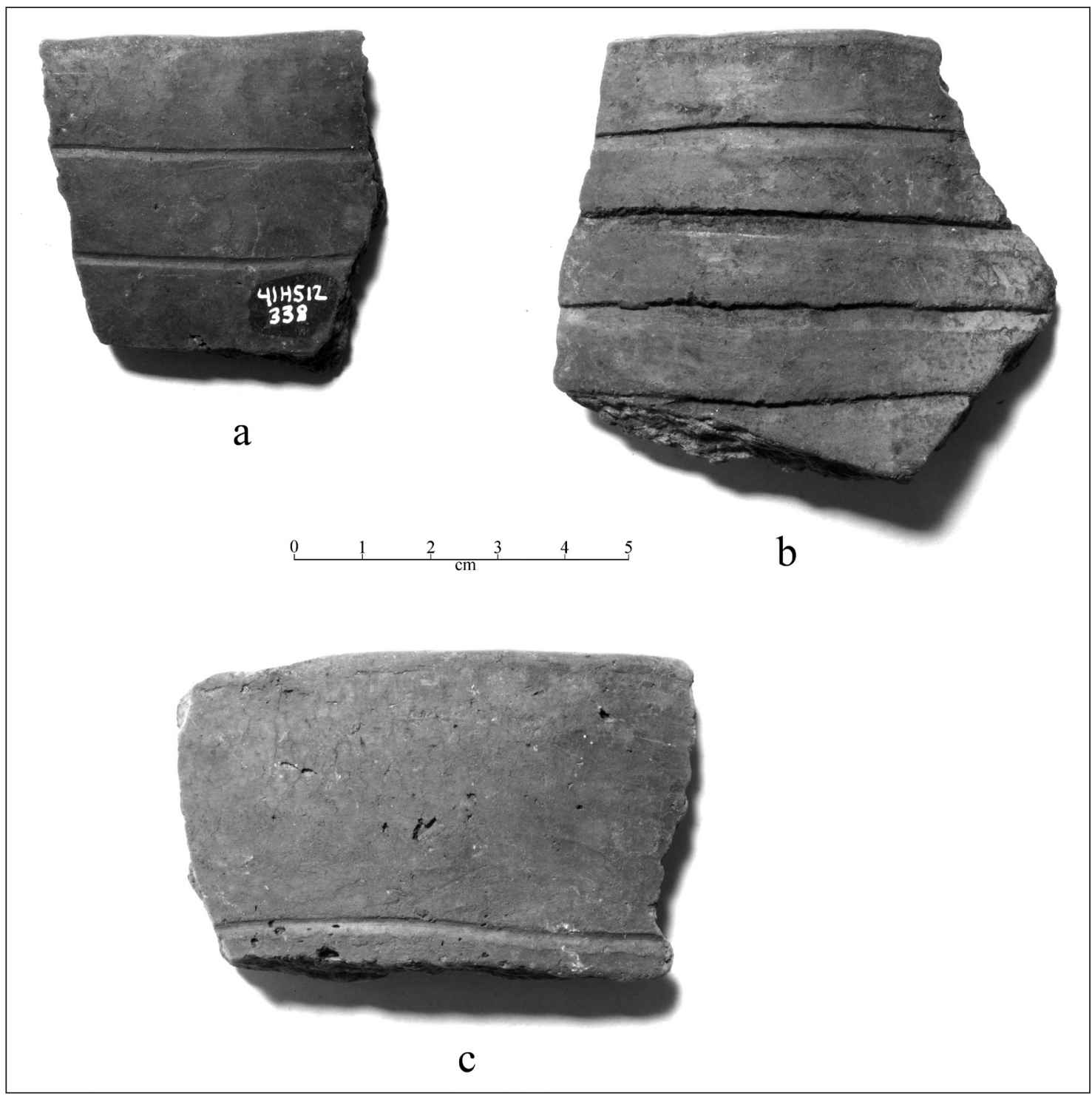

Figure 37. Coles Creek Incised, var. Coles Creek and Coles Creek Incised, var. unspecified rim sherds in the midden deposits: a-b, Coles Creek Incised, var. Coles Creek; c, Coles Creek Incised, var. unspecified. Provenience: a, N97 E111, 0-5 cm in the midden; b, N97 E115, 0-10 cm in midden; c, N97 E113, midden surface.

1.5 percent of the decorated sherds in the sub-mound midden component at the site. These sherds have vertical and straight-parallel pinched ridges covering the rim and body.

Only a single punctated sherd (0.8 percent) is represented in the sub-mound midden deposit assemblage. This is a body sherd with rows of punctations (see Table 13).

The assemblage from sub-mound midden contexts has five non-descript engraved vessel body sherds from fine ware vessels, with curvilinear to straight engraved lines in uncertain motifs or undefined elements. At 3.8 percent of the decorated sherd assemblage, they are nowhere near as common in this deposit when compared to their proportional frequencies in the Area B and the Mound fill deposits (see Table 8). 


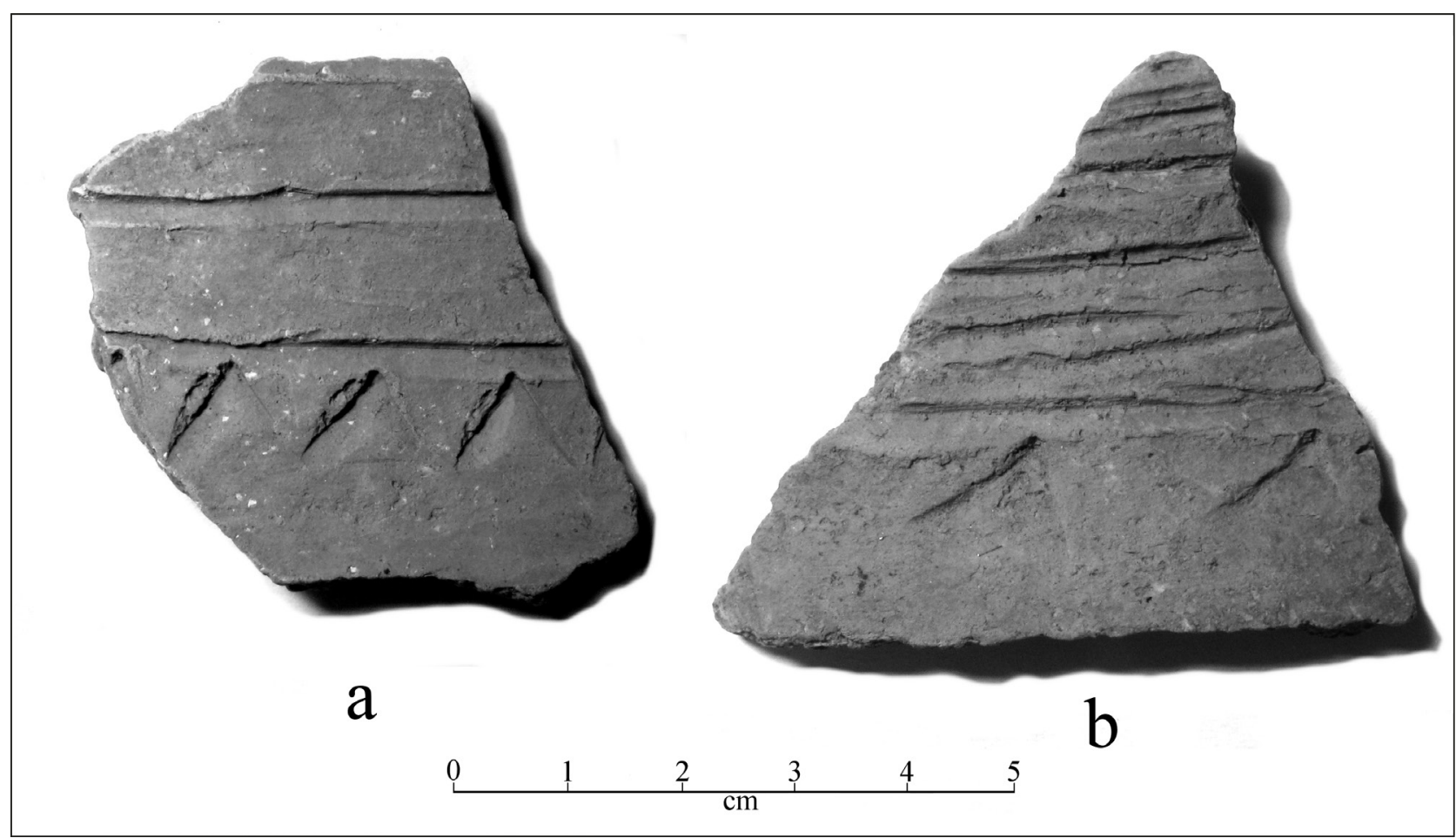

Figure 38. Coles Creek Incised, var. Coles Creek sherds with horizontal incised lines and lower impressed triangles. Provenience: a, N97 E115, 0-10 cm in midden; b, N97 E113, midden surface.

\section{Area B}

A total of 11 decorated rim and body sherds were recovered in Area B, a habitation area near the mound at the Mound Pond site. They include fingernail punctated, band punctated, incised, and engraved sherds (Table 14). The two rims are from horizontal incised vessels, but neither have overhanging incised lines, and may be from Davis Incised vessels. The one horizontal incised sherd that has overhanging and closely-spaced lines may be from a Coles Creek Incised, var. Mott vessel (see Brown 1998:9). One sherd has a band punctated decoration; that is, a row of punctations has been placed between a band of horizontal incised lines. Sherds from vessels with this decorated motif have been considered to be of Early Caddo period age (cf. Webb 1963:Figure 9r-s, u; Jeffrey S. Girard, April 2010 personal communication; Perttula 2011a:23 and Figure 10a).

Table 14. Area B decorated sherds.

\begin{tabular}{lccc}
\hline Decoration & Rim & Body & N \\
\hline $\begin{array}{l}\text { Fingernail punctated, free } \\
\text { Fingernail punctated, single punctate }\end{array}$ & - & 1 & 1 \\
Band [incised-]punctated & - & 1 & 1 \\
$\begin{array}{l}\text { Horizontal incised lines, closely- } \\
\text { spaced, overhanging, Coles Creek Incised } \\
\text { Horizontal incised lines, closely-spaced }\end{array}$ & - & 1 & 1
\end{tabular}


Table 14. Area B decorated sherds, cont.

\begin{tabular}{lccc}
\hline Decoration & Rim & Body & N \\
\hline Horizontal incised lines & 1 & - & 1 \\
Parallel incised lines & - & 2 & 2 \\
Single straight incised line & - & 1 & 1 \\
$\begin{array}{l}\text { Curvilinear engraved lines } \\
\text { Horizontal, vertical, and diagonal } \\
\text { engraved lines, carinated bowl }\end{array}$ & - & 1 & 1 \\
\hline Totals & - & 1 & 1 \\
\hline
\end{tabular}

Both fine ware sherds in the Area B decorated sherd assemblage are from engraved vessels. The decorative elements suggest that both sherds may be from two different Holly Fine Engraved bowls, beakers, or carinated bowls (see Suhm and Jelks 1962:Plates 39 and 40).

\section{Orifice Diameter of Decorated Rim Sherds}

Twenty-eight decorated rim sherds from the mound $(n=10)$ and sub-mound midden $(n=18)$ deposits at the Mound Pond site were large enough in circumference to measure their orifice diameter, and thus obtain information relating to vessel size in both archaeological contexts. The measurable sub-mound midden rim sherds have a mean orifice diameter of $20.9 \pm 4.3 \mathrm{~cm}$, with a range from $13-32 \mathrm{~cm}$. The rim sherds from mound deposits are smaller, with a mean orifice diameter of $18.4 \pm 3.6 \mathrm{~cm}$; the range is $11-28 \mathrm{~cm}$. In both cases, the decorated sherds are from vessels that are larger than the plain wares (see Marceaux, above), but the range in sizes point to their use by both individuals and communal groups of people.

\section{Technological Parameters of the Decorated Sherds}

A sample of decorated sherds from the mound and sub-mound midden assemblages were analyzed in detail to gather information on temper use, firing conditions, surface treatment, and vessel wall thickness (Appendix 4). Grog temper was the preferred temper inclusion in the decorated sherds in both ceramic assemblages, although its use is more common in the sub-mound midden deposits. This was also the case in the plain wares from both contexts (see Table 4).

Table 15. Temper and paste attributes in the decorated sherds from the Mound Pond site.

\begin{tabular}{lcc}
\hline Temper-paste categories & Mound & Sub-mound Midden \\
\hline grog & & 85.7 \\
grog-sandy paste & - & 7.1 \\
grog-bone & 13.3 & 7.1 \\
grog-hematite-sandy paste & 6.7 & - \\
bone & 3.3 & - \\
bone-grog & 3.3 & - \\
no temper-sandy paste & 3.3 & -
\end{tabular}


Table 15. Temper and paste attributes in the decorated sherds from the Mound Pond site, cont.

\begin{tabular}{lcc} 
Temper-paste categories & Mound & Sub-mound Midden \\
\hline Summary: & 93.4 & 100.0 \\
sherds with grog temper & 20.0 & 7.1 \\
sherds with bone temper & 6.7 & - \\
sherds with hematite temper & 10.0 & 7.1 \\
sherds with sandy paste & 30 & 14 \\
\hline Totals & 30 \\
\hline
\end{tabular}

* percentage

Crushed pieces of burned bone and hematite were also used as tempering materials, particularly in the mound deposits (see Table 15). Bone temper was much more abundant in the plain wares from the mound deposits compared to the plain wares in the sub-mound midden deposits, and this is the case with the decorated vessel sherds. However, bone-tempered decorated sherds are between 21-33 percent less frequent than are bone-tempered plain ware sherds. Hematite-tempered sherds are absent in the decorated sherd assemblage in sub-mound midden deposits. Sherds from sandy paste vessels represent 7.1-10 percent of the decorated sherds in the two assemblages, and the use of a naturally sandy clay is a bit more common in the mound deposits. A similar case of sandy paste vessel sherds is noted in the plain ware sherds (see Table 4).

Data on the firing conditions observed in the decorated sherds from both mound and sub-mound midden contexts indicate that they are from vessels most commonly fired in a reducing or low oxygen environment: 80 percent in the mound deposits, and 85.8 percent in the sub-mound midden deposits (Table 16). In the plain wares, between 62.0-72.9 percent of the sherds are from vessels fired in a reducing environment (see Table 5). Most of the reduced-fired sherds, especially in the mound deposits for both plain and decorated sherds (60.3-63.3 percent), were from vessels that were subsequently cooled in the open air; in the sub-mound deposits, sherds from vessels fired in this manner comprise 45.5-62 percent of the plain and decorated sherd samples.

Table 16. Firing conditions in the decorated sherds from the Mound Pond site.

\begin{tabular}{lcc} 
Firing condition & Mound & Sub-mound Midden \\
\hline Oxidizing (A) & $13.3^{*}$ & 7.1 \\
Incompletely Oxidized (C-E) & 3.3 & - \\
Reducing (B) & 16.7 & 42.9 \\
Reducing and cooled in open air (F-H) & 63.3 & 42.9 \\
Sooted, smudged, re-heated (I-L) & 3.3 & 7.1 \\
\hline Totals & 30 & 14 \\
\hline
\end{tabular}

*percentage 
Vessels fired in an oxidizing environment are not common in the Mound Pond ceramic assemblages, either in the plain sherds (6.9-13.3 percent) or in the decorated sherds (7.1-13.3 percent) (see Tables 5 and 16). However, sherds from incompletely oxidized vessels are much more common in the plain wares, regardless of context (15.3-26.7 percent), than is the case among the decorated wares (0-3.3 percent). Finally, sherds from sooted, smudged, or reheated vessels are more common among the decorated wares (3.3-7.1 percent) than they are among the plain wares (0.7-1.0 percent). These differences in firing conditions between the mound and sub-mound midden deposits, and between the plain and decorated wares, likely relates to the differences in the intended functions and uses of the Mound Pond ceramic wares for cooking, food serving, and as containers for liquids.

As with the plain sherds discussed above, the decorated sherds from the Mound Pond site are thickest in the sub-mound midden assemblage than they are in the overlying mound deposits, most notably in the rim sherds. The rim sherds in the sub-mound midden have a mean thickness of $7.59 \mathrm{~mm}$, compared to $6.88 \mathrm{~mm}$ in the mound assemblage. The decorated rim sherds are from thicker vessels than the plain wares $(6.2-6.7 \mathrm{~mm})$ in both assemblages. Decorated body sherds in the mound and sub-mound midden assemblages are virtually the same thickness: $6.87 \mathrm{~mm}$ (mound) and $6.89 \mathrm{~mm}$ (sub-mound midden).

\section{Summary of the Ceramic Assemblages}

Girard (2009a:27-28) has developed a relatively detailed ceramic chronology for the early Caddo occupations along the Red River in Northwest Louisiana that appears to be directly relevant to understanding the age and ceramic character of the Mound Pond ceramic assemblage. He noted that:

between A.D. 900 and 1050, decorated specimens increased in number, but still constituted only about 10 percent or less of most assemblages. Horizontal incising was common, and distinctive elements associated with Coles Creek Incised, var. Coles Creek (overhanging lines, sometimes with underlying triangular punctations) often occurred. I suspect that the type Weches Fingernail Punctated is a regional variant of this Coles Creek theme. Body sherds with large fingernail punctations (e.g., Kiam Punctated Incised) also appeared. This interval might be the time of initial use of engraved pottery, although percentages were very low (Girard 2009a:27-28).

The ceramics from this era, as best exemplified by sub-mound midden deposits in several contexts at the Mounds Plantation site on the Red River, bear strong resemblances to the sub-mound midden assemblage of decorated sherds from the Mound Pond site. On first reflection, it seemed likely that the submound midden assemblage at Mound Pond would also date to this 10th and mid-11th century A.D. temporal interval. The calibrated radiocarbon dates from sub-mound midden deposits, however, range as late as the early 12th to the early 13th century A.D. in current calibration curves, almost a century later than

expected based on the character of Northwest Louisiana Early Caddo ceramic assemblages. It is possible, however, that the flattening of the calibration curve at this time may mean that the sub-mound midden dates may better relate to the mid- to late 11th century. In any case, more radiocarbon dates are warranted from both sub-mound and mound deposits at the Mound Pond site.

Girard (2009b:52) had also suggested that there was a period of strong Lower Mississippi Valley Coles Creek influence among Caddo peoples in parts of the Caddo area between ca. A.D. 900-1050, and this influence (and presumably considerable contact) would be most notably detected in the character of the ceramic wares from the Mound Pond site, especially in the sub-mound midden deposits, and in the ceramic assemblages at sites like James Pace and Mounds Plantation (Table 17). That period of influence may have lasted longer in the Mound Pond area than it did in the major mound centers, where we might expect more rapid changes in ceramic vessel designs and styles. 
Table 17. Sherd assemblage comparisons between the Mound Pond site and selected sites in Northwest Louisiana and East Texas.

Ceramic Categories

Sites

\begin{tabular}{|c|c|c|c|c|c|}
\hline & \multirow[t]{2}{*}{$\underline{\text { Pace }}$} & \multicolumn{4}{|c|}{ Mound Plantation contexts: } \\
\hline & & Md. 2 & $\begin{array}{r}\text { Borrow } \\
\text { Pit }\end{array}$ & $\begin{array}{l}\text { Md. 3, } \\
\text { pre-md. }\end{array}$ & Md. 3 \\
\hline Plain sherds & 2282 & 636 & 380 & 249 & 655 \\
\hline Decorated & 561 & 55 & 60 & 36 & 109 \\
\hline $\mathrm{P} / \mathrm{DR}$ & 4.1 & 11.6 & 6.3 & 6.9 & 6.0 \\
\hline Beldeau Incised & $1 \%$ & - & - & - & $1 \%$ \\
\hline Punctated & $2 \%$ & - & $3 \%$ & $6 \%$ & $2 \%$ \\
\hline Incised & $21 \%$ & $73 \%$ & - & - & - \\
\hline Coles Creek Incised & $72 \%$ & $7 \%$ & $92 \%$ & $75 \%$ & $50 \%$ \\
\hline Crockett Curvilinear Incised & $\mathrm{T}$ & $4 \%$ & - & - & - \\
\hline Hollyknowe Ridge Pinched & $1 \%$ & $2 \%$ & $2 \%$ & - & $1 \%$ \\
\hline Incised-Punctated & $1 \%$ & - & - & - & $3 \%$ \\
\hline Appliqued & $\mathrm{T}$ & - & - & - & - \\
\hline Engraved & $1 \%$ & $7 \%$ & - & $14 \%$ & $22 \%$ \\
\hline Grooved & - & - & - & - & - \\
\hline Band-Punctated & - & - & - & - & - \\
\hline Lip Notched & - & - & - & - & - \\
\hline Incised-Pinched & - & - & - & - & - \\
\hline French Fork Incised & - & - & $3 \%$ & - & - \\
\hline $\begin{array}{l}\text { Weches Fingernail } \\
\text { Impressed }\end{array}$ & - & - & - & - & - \\
\hline $\begin{array}{l}\text { cal C14 age range } \\
\text { (A.D.) }\end{array}$ & $\begin{array}{c}780- \\
1010\end{array}$ & $\begin{array}{l}981- \\
1146\end{array}$ & - & - & - \\
\hline \multicolumn{2}{|l|}{ Ceramic Categories } & Sites & & & \\
\hline$\frac{\text { Mound Pla }}{\text { Md. 6, } \mathrm{st}}$ & $\begin{array}{l}\text { itation } \\
\text { ib-md. } \\
\text { aidden }\end{array}$ & $\frac{\text { Grace Creek }}{\underline{\# 1}}$ & $\begin{array}{r}\text { Boxed } \\
\text { Springs }\end{array}$ & $\frac{\text { Mound }}{\underline{\text { Pond }}}$ & \\
\hline Plain sherds & 153 & N/A & 718 & - & \\
\hline Decorated & 16 & 343 & 153 & 133 & \\
\hline $\mathrm{P} / \mathrm{DR}$ & 9.6 & N/A & 4.7 & N/A & \\
\hline
\end{tabular}


Table 17. Sherd assemblage comparisons between the Mound Pond site and selected sites in Northwest Louisiana and East Texas, cont.

Ceramic Categories

Sites

$\begin{array}{rrrr}\frac{\text { Mound Plantation }}{\text { Md. 6, sub-md. }} & \text { Grace Creek } & \underline{\text { Boxed }} & \underline{\text { Mound }} \\ \begin{array}{r}\text { midden }\end{array} & \underline{\text { Springs }} & \underline{\text { Pond }} \\ \text { sub-md. }\end{array}$

\begin{tabular}{lrrrr}
\hline Beldeau Incised & - & $1 \%$ & - & - \\
Punctated & - & $7 \%$ & $17 \%$ & $1 \%$ \\
Incised & $88 \%$ & $66 \%$ & $35 \%$ & $51 \%$ \\
Coles Creek Incised & - & $13 \%$ & $3 \%$ & $41 \%$ \\
Hollyknowe Ridge Pinched & - & $3 \%$ & $6 \%$ & $2 \%$ \\
Incised-Punctated & - & $7 \%$ & $2 \%$ & $2 \%$ \\
Appliqued & - & - & $1 \%$ & - \\
Engraved & $13 \%$ & $6 \%$ & $35 \%$ & $4 \%$ \\
Grooved & - & - & $1 \%$ & - \\
Band-Punctated & - & $\mathrm{T}$ & $1 \%$ & - \\
Lip Notched & - & $1 \%$ & - & $2 \%$ \\
Incised-Pinched & - & $1 \%$ & - & - \\
French Fork Incised & - & $1 \%$ & - & - \\
Weches Fingernail Impressed & - & $1 \%$ & - & - \\
& & & $970-$ & - \\
cal C14 age range & $981-1045$ & - & 1260 & \\
(A.D.) & & & &
\end{tabular}

T=Trace percentage (less than 1 percent); Sources: James Pace (Story 1990a:Table 77; see also Girard 1992); Mounds Plantation (Webb and McKinney 1975:Table 1; Girard 2009b:Table 3; Jeffrey Girard, April 2010 e-mail communication); Grace Creek \#1 (Perttula 2011a); Boxed Springs (Perttula 2011b:Table 5).

The sherds in the sub-midden deposits at the Mound Pond site are dominated by horizontal incised Coles Creek Incised types with overhanging lines. The Borrow Pit and sub-mound midden deposits in Mounds 3 and 6 at Mounds Plantation are the same, as they contain substantial amounts of Coles Creek Incised ceramics (see Table 17). Radiocarbon dates from these Mounds Plantation deposits range from the late 10th to the early to mid-11th century A.D. (Girard 2012:Table 6); one date from a midden deposit near Mound 2 has a 2 sigma calibration of A.D. 1030-1160, generally contemporaneous with one of the calibrated dates from Mound Pond. The other calibrated dates from Mound Pond sub-mound midden deposits suggest that this distinctive Early Caddo occupation dates to the 11th and 12th centuries A.D.

The occurrence and relative proportion of Coles Creek Incised pottery in ceramic assemblages from prehistoric Late Woodland and Early Caddo sites in Northwest Louisiana is considerable, dwarfing its use on East Texas Caddo sites of the same age (Story 1990b), with the exception of the Mound Pond site. At the Mounds Plantation site, in pre-A.D. 1050 archaeological deposits, Coles Creek Incised (or related horizontal incised sherds) comprise between 91.6-100 percent of the decorated sherds; the plain to decorated sherd ratios in these occupations range from 6.3-9.6 (i.e., between 9-15 percent of the sherds are decorated), indicating that there may well have been many plain vessels in these same assemblages. At the James Pace site (with median calibrated ages of A.D. 780 and A.D. 1010 [see Girard 1994; McGimsey and van der Koogh 2001) on the Sabine River, apparently occupied between ca. A.D. 
800-1000, Coles Creek Incised pottery, including var. Hardy ( $\mathrm{n}=190)$, var. Coles Creek ( $\mathrm{n}=87)$, var. Mott $(\mathrm{n}=71)$, and var. Greenhouse or var. Blakely $(\mathrm{n}=6)$, accounts for 72 percent of the decorated sherds (Story 1990a:Table 77). Engraved sherds only account for 1.2 percent of the decorated sherds from the James Pace site, and the Borrow Pit at the Mounds Plantation site did not have any engraved pottery.

The mound deposits at Mound Pond have a more diverse decorated ceramic assemblage than the submound midden deposits, and must date as late as ca. A.D. 1200 based on the results of recent radiocarbon dating of charred plant remains samples from the sub-mound midden. Incised sherds remain common in the assemblage, but with few Coles Creek Incised vessel sherds. More common in the assemblage, which dates later than the sub-mound midden deposit, are incised-punctated, punctated, band punctated, engraved, and slipped sherds. Engraved sherds comprise almost 7 percent of the decorated sherds from the Mound Pond site mound deposit assemblage. Similar decorated sherd assemblages have been dated to as late as cal A.D. 1260 at the Boxed Springs site, but engraved sherds constitute 35 percent of the decorated sherd assemblage there (see Table 17), suggesting an important trend in fine ware manufacture and use in East Texas Caddo sites that may have occurred ca. A.D. 1200.

Engraved pottery at the Mounds Plantation site are found in contexts that have calibrated radiocarbon age ranges of A.D. 989-1257 (see Table 17). In sherd assemblages they account for no more than 7.9-22 percent of the decorated sherds, while they account for 80 percent of the vessels from the Mound 5 burial pits. In other Northwest Louisiana ceramic assemblages, and the Crenshaw site, fine wares are not common before cal A.D. 1000, and even after that date, engraved wares are not as well represented in these sites compared to contemporaneous East Texas Caddo sites; Mound Pond is an important exception when it comes to the use of engraved wares, as is also the case at the Grace Creek site in the Sabine River (see Table 17 and Perttula [2011a]). In the pre-A.D. 1200 Smithport Landing, 16BO450, 16BO473, and Hanna sites, in Northwest Louisiana, for example, engraved sherds only account for between 3-20 percent of the decorated sherds (see Perttula 2011b:Table 14).

In sum, the ceramic assemblages from the sub-mound midden and mound deposits at the Mound Pond site are culturally distinctive, particularly when considered with respect to the 11 th and 12 th century A.D. radiocarbon dates that have been obtained from the sub-mound midden deposits. The sub-mound midden deposits are defined by the high frequencies of horizontal incised vessels, many of them identified as several varieties of Coles Creek Incised. Very similar Northwest Louisiana ceramic assemblages appear to date one or two generations earlier, namely from the late 10th century to the mid-11th century. The ceramics from the mound deposits at Mound Pond resemble Early Caddo assemblages from both East Texas and Northwest Louisiana, with a considerable number of incised, punctated, and incised-punctated vessel sherds, and relatively low frequencies of engraved fine ware sherds. Given the stratigraphic position of the mound deposits relative to the sub-mound midden deposits - in combination with the calibrated ages of the sub-mound midden radiocarbon dates - the mound ceramics at Mound Pond apparently date to the early years of the 13 th century A.D.

\section{Ceramic Ear Spool}

A single ceramic ear spool was found in shallow (level 2 below the modern ground surface) mound deposits in N100 E108 (Figure 39). The ear spool (4.6 mm thick) has a pronounced exterior flange, and is virtually identical in style and form to ear spools from Early Caddo contexts at the Hudnall-Pirtle site (41RK4, Bruseth and Perttula 2006:Figure 29d-e). 


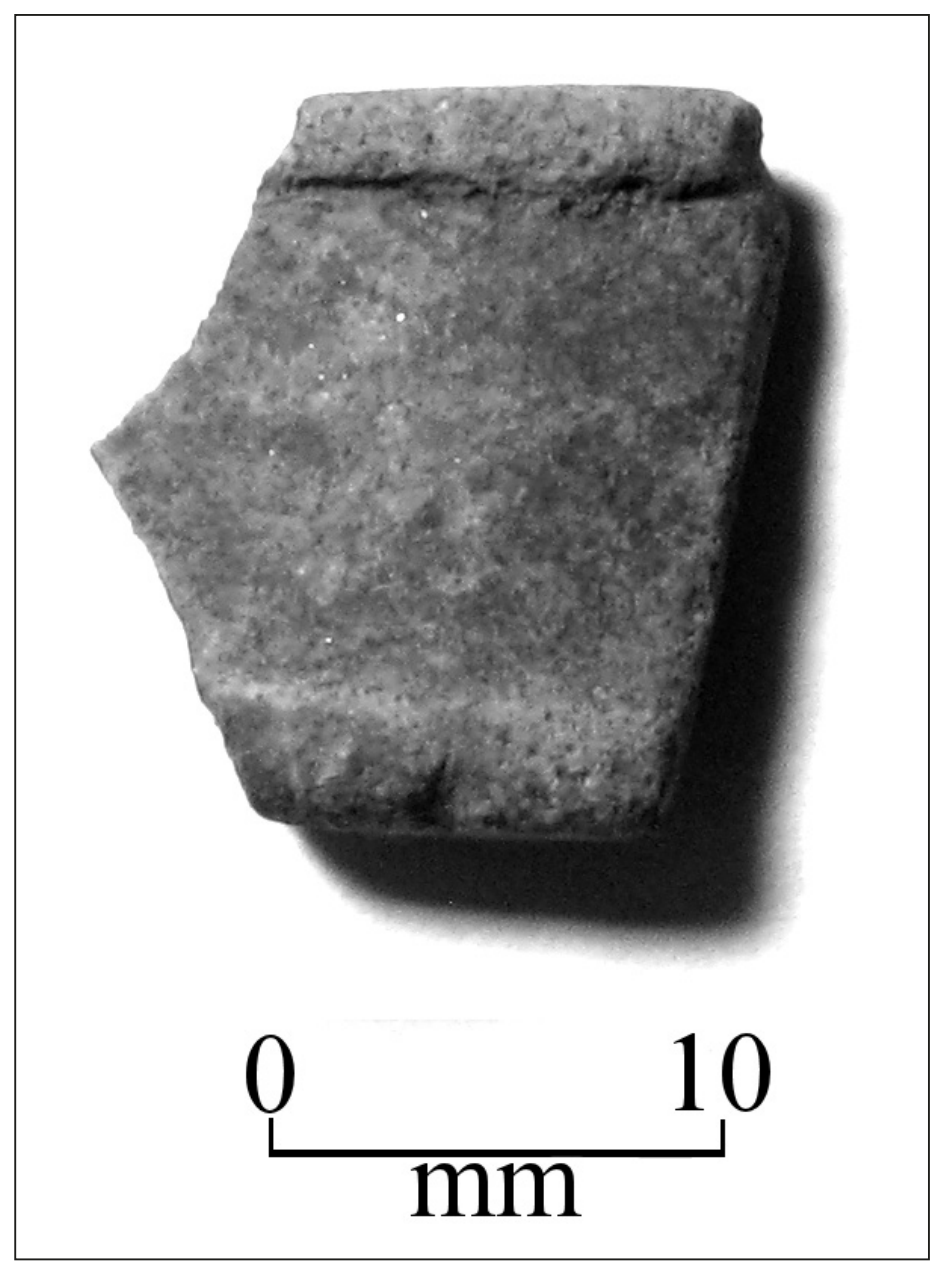

Figure 39. Ceramic Ear Spool from the Mound Pond site.

\section{Burned Clay, Daub, and Mud Dauber Nests}

Several small pieces of burned clay were present in the archaeological deposits, including: N97 E113, 0-10 cm in midden $(n=1)$ and N110 E118, level $1(n=1)$, in the uppermost mound deposits. One piece of daub was recovered in the upper mound deposits (N100 E106, 35-50 cm bs).

The midden deposits under the mound (N100 E110, $175 \mathrm{~cm} \mathrm{bs}$ ) contained three small pieces of mud dauber nests as well as a larger chamber covering two large mud dauber nests. The concentration of mud dauber nest pieces in this unit, and at this depth, suggest that the midden deposits accumulated near or in a standing structure that likely burned down, preserving the mud dauber nests that were attached to one of the walls or roof of the wood structure. ${ }^{2}$ 


\section{Chapter 6, Faunal Analysis from the Mound Pond Site: an Early Caddo Mound Site in Harrison County, Texas}

\section{LeeAnna Schniebs}

Archaeological investigations at the Mound Pond site (41HS12) in 1977 by students from the University of Texas and various avocational archaeologists yielded a total of 443 faunal specimens; the absence of fish remains is notable. Total weight of the collection is 69.4 grams, and 84 (19 percent) bone fragments are identifiable. The majority of the faunal assemblage is burned ( $\mathrm{n}=368,83$ percent). In general, the sample is fragmented but these small pieces are fairly well preserved and most bone surfaces are undamaged. The high rate of fragmentation is likely due in part to laboratory or processing conditions. Table 18 summarizes the results of the faunal analysis.

Table 18. Summary of faunal taxonomic recovery from the Mound Pond site (41HS12).

\begin{tabular}{lccccc}
\hline Taxon & NISP & MNI & Habitat* & Percent & $\begin{array}{c}\text { No. } \\
\text { Burned }\end{array}$ \\
\hline Vertebrata (indeterminate) & 20 & - & - & 4.5 & 20 \\
Musk/Mud turtle (Kinosternidae) & 1 & 1 & A & 0.2 & - \\
Indeterminate turtle (Testudinata) & 12 & - & - & 2.7 & 9 \\
$\begin{array}{l}\text { White-tailed deer } \\
\text { Odocoileus virginianus) }\end{array}$ & 71 & 1 & WE & 16.0 & 34 \\
Mammal (size indeterminate) & 146 & - & - & 33.0 & 131 \\
Mammal (small Mammalia) & 63 & - & - & 14.2 & 63 \\
Mammal (large Mammalia) & 130 & - & - & 29.3 & 130 \\
\hline Total & 443 & 2 & & 100 & 368 \\
\hline
\end{tabular}

NISP=number of identified specimens; $\mathrm{MNI}=$ minimum number of individuals

* Preferred Habitat (Davis 1978): A=aquatic (rivers, swamps, marshes); WE=wooded edges (open meadows, parkland).

Standard zooarchaeological identification techniques were employed in this analysis, using comparative skeletal collections. Attributes that were examined for each of the bone fragments include taxon, element and portion of that element, symmetry, burning, and weight. This analysis is concerned with identifying general animal exploitation preferences of the Early Caddo peoples that lived at this particular site in the East Texas Pineywoods.

The faunal remains were recovered from 16 proveniences (including the combined grid eastings of 109 and 111 on the North Wall and midden recovery); 45 specimens are from unknown locations. Depths range from 0 to $175 \mathrm{~cm}$ bs in the archaeological deposits (Table 19). 
Table 19. Distribution of Mound Pond site (41HS12) Faunal Remains by Provenience.

\begin{tabular}{|c|c|c|c|}
\hline $\begin{array}{l}\text { Provenience } \\
\text { (North/East; cm bs) }\end{array}$ & Taxon & NISP & $\begin{array}{l}\text { Total NISP } \\
\text { by Unit level }\end{array}$ \\
\hline \multicolumn{4}{|l|}{ Sub-Mound Midden Deposits } \\
\hline N93/E115, 0-10 & indeterminate mammal & 35 & 35 \\
\hline N95/E110, 0-10 & small mammal & 9 & 9 \\
\hline \multirow[t]{2}{*}{ N95/E110, 10-15 } & unidentifiable & 17 & \\
\hline & large mammal & 3 & 20 \\
\hline \multirow[t]{3}{*}{ N95/E110, 15-20 } & unidentifiable & 2 & \\
\hline & deer & 2 & \\
\hline & large mammal & 5 & 9 \\
\hline \multirow[t]{2}{*}{ N95/E111, 0-15 } & deer & 10 & \\
\hline & indeterminate mammal & 6 & 16 \\
\hline N97/E109, surface & indeterminate mammal & 6 & 6 \\
\hline \multirow[t]{3}{*}{ N97/E109, 5-10 } & deer & 1 & \\
\hline & indeterminate mammal & 20 & \\
\hline & large mammal & 9 & 30 \\
\hline N97/E110, 5-10 & indeterminate mammal & 10 & 10 \\
\hline \multirow[t]{4}{*}{ N97/E111, 0-5 } & turtle & 2 & \\
\hline & deer & 3 & \\
\hline & indeterminate mammal & 21 & \\
\hline & large mammal & 20 & 46 \\
\hline N97/E111, 5-10 & indeterminate mammal & 2 & 2 \\
\hline \multirow[t]{2}{*}{ N97/E115, 0-10 } & deer & 12 & \\
\hline & large mammal & 26 & 38 \\
\hline \multirow[t]{2}{*}{ N97/E109+111, North Wall } & deer & 1 & \\
\hline & large mammal & 2 & 3 \\
\hline $\begin{array}{l}\mathrm{N} 100 / \mathrm{E} 108, \text { surface to } \\
5 \mathrm{~cm} \text { in midden }\end{array}$ & large mammal & 5 & 5 \\
\hline N100/E110, 175 (midden) & small mammal & 15 & \\
\hline large mammal & & 3 & 18 \\
\hline
\end{tabular}


Table 19. Distribution of Mound Pond site (41HS12) Faunal Remains by Provenience, cont.

\begin{tabular}{|c|c|c|c|}
\hline $\begin{array}{l}\text { Provenience } \\
\text { (North/East; cm bs) }\end{array}$ & Taxon & NISP & $\begin{array}{l}\text { Total NISP } \\
\text { by Unit level }\end{array}$ \\
\hline
\end{tabular}

Sub-Mound Midden Deposits

N100/E110, midden

deer 1

indeterminate mammal $\quad 15$

large mammal 17

Subtotal, sub-mound Midden Deposits

Mound Deposits

N100/E100, 50-65

deer

4

large mammal 13

17

N100/E102, 35-50

turtle

1

N100/E106, Level 2

large mammal

2

N100/E108, 127-150

small mammal

39

N100/E133, 0-15

musk/mud turtle

turtle

N100/E133, 15-30

turtle

large mammal

N110/E118, 0-5

large mammal

Unit 1, 15-30

unidentifiable

turtle

17

Unit 1, 45-60

deer

indeterminate mammal large mammal

Subtotal, Mound Deposits

General Site

$\begin{array}{lr}\text { turtle } & 5 \\ \text { deer } & 21 \\ \text { indeterminate mammal } & 14 \\ \text { large mammal } & 5\end{array}$


Despite the high quantity of unidentifiable faunal remains and severe fragmentation, a few inferences can be made about the Mound Pond site faunal sample. The musk/mud turtle shell fragment suggests that the site is located near a water source (i.e., Big Cypress Creek), and that aquatic habitat was utilized. At least some of the 12 indeterminate turtle shell fragments compare favorably to box turtle, and woodlands and bottomlands were probably exploited. The box turtle is a slow-moving animal and is easily caught when the occasion arises by passive hunting methods, often by women or children. There is no evidence of the larger pond turtles, which is surprising as they are usually common in East Texas Caddo faunal collections. The deer molar is from an individual approximately seven months of age at time of death; this deer was killed in the late summer since fawns are born in the early spring. The other deer elements recovered appear to be from an older individual based on their size and the fused epiphyses on the long bones.

Most of the unidentifiable large mammal bone fragments are probably deer remains, inferring that wooded edges were utilized for hunting. The unidentifiable small mammal bones could be cottontail, squirrel, pocket gopher, or any other small rodent as these are common in Caddo faunal assemblages. The indeterminate vertebrate remains could represent any taxonomic class.

Hunting was probably done in all seasons throughout the year. The high rate of burning suggests subsistence preparation and subsequent debris disposal. Further investigations at the Mound Pond site could provide additional information as to the subsistence preferences and animal hunting activities of Early Caddo peoples.

\section{Faunal Assemblage Comparisons}

\section{Timothy K. Perttula}

Although the sample sizes of faunal remains from the sub-mound midden $(n=280)$ and the mound deposits $(\mathrm{n}=118)$ are rather small, it is worth noting that the faunal assemblages do differ between the two temporally sequent occupations, with the later mound deposits more diverse in composition. In the earlier sub-mound midden deposits, the faunal assemblage is dominated by deer and large mammal bones (also likely deer), accounting for 82.1 percent of the identifiable remains (Table 20). In the mound deposits, on the other hand, while deer and large mammal bones are also abundant (53.4 percent), small mammal and turtle remains are from two to four times as common in this assemblage when compared to the earlier midden deposits under the mound.

Table 20. Faunal assemblage comparisons between the mound and sub-mound midden deposits at the Mound Pond site.

\begin{tabular}{lcllll}
\hline Assemblage & $\begin{array}{c}\text { Small } \\
\text { Mammal }\end{array}$ & $\begin{array}{l}\text { Large } \\
\text { Mammal }\end{array}$ & Deer & Turtle & N \\
\hline $\begin{array}{l}\text { Sub-mound } \\
\text { Midden }\end{array}$ & $16.6 \%$ & $\underline{\mathbf{6 1 . 4 \%}}$ & $\underline{\mathbf{2 0 . 7 \%}}$ & $1.4 \%$ & 145 \\
Mound & $\underline{\mathbf{3 7 . 8 \%}}$ & $34.0 \%$ & $19.4 \%$ & $\underline{\mathbf{5 . 8 \%}}$ & 103 \\
\hline
\end{tabular}

Note: bold and underlined entries indicate significant differences by row in the proportions of several faunal categories

How does the Mound Pond fauna compare to other Early Caddo mound centers and settlements in East Texas and Northwest Louisiana that have reasonably well-preserved faunal remains? In general, 
large mammal (probably primarily deer, although unidentifiable to genus) and deer were important animal foods, contributing meat and fat to the diet in other Early Caddo sites, in addition to bone and hides as raw materials for clothing, tools, and ornaments (Table 21). Fish were not apparently gathered by the Caddo peoples that lived at Mound Pond.

Table 21. Faunal assemblage composition on other Caddo sites dating from ca. AD.970-1200.

\begin{tabular}{|c|c|c|c|c|}
\hline Sites/Age & $\% \mathrm{LM}$ & $\%$ Deer & $\%$ Fish & $\%$ Turtle \\
\hline $\begin{array}{l}\text { Charles Webb (16RR86) } \\
\text { A.D. 900-1000 } \\
\text { Hunter et al. 2002:Table } 20\end{array}$ & 44.8 & 27.6 & 7.2 & 14.1 \\
\hline $\begin{array}{l}\text { Taddlock (41WD482) } \\
\text { A.D. } 970-1160 \\
\text { Bruseth and Perttula } \\
\text { 1981:Table } 7-3\end{array}$ & N/A & 8.6 & 45.6 & 26.4 \\
\hline $\begin{array}{l}\text { Boyette (41NA285) } \\
\text { A.D. } 880-1080 \\
\text { Schniebs 2008: } \\
\text { Table 10-5 }\end{array}$ & 50.0 & 18.0 & - & 9.0 \\
\hline $\begin{array}{l}\text { Broadway (41SM273) } \\
\text { A.D. 900-1000 } \\
\text { Perttula and Nelson } \\
\text { 2004:Table } 54\end{array}$ & 49.1 & 17.7 & - & 13.3 \\
\hline $\begin{array}{l}\text { Boxed Springs (41UR30) } \\
\text { A.D. 970-1200 } \\
\text { Schniebs 2011:Table } 27\end{array}$ & 53.4 & 37.2 & - & 3.3 \\
\hline $\begin{array}{l}\text { Hudnall-Pirtle (41RK4) } \\
\text { A.D. 1000-1200 } \\
\text { Yates 2006:Table } 13\end{array}$ & $15.0^{*}$ & 75.0 & - & 7.2 \\
\hline
\end{tabular}

*possible bison present; LM=large mammal

The Charles Webb and Taddlock sites have different faunal characteristics than the other Early Caddo sites, including Mound Pond. While the other sites are dominated by large-sized mammals, deer, and turtle (as well as other animal species), the former sites have more fish and turtle, especially at the ca. A.D. 970-1160 Taddlock occupation on Lake Fork Creek in the Sabine River basin (Bruseth and Perttula 1981). Although fish is present in the ca. A.D. 900-1000 assemblage at the Charles Webb site on the Red River, the relative proportions of large animals, deer, and turtle are very similar to that of the Broadway site in the upper Angelina River basin (Perttula and Nelson 2004). Jackson (1981) and Davidson (1997) have also both noted that deer, turtle, and fish were common in the faunal assemblages from the George C. Davis site, a large Early Caddo mound center on the Neches River in East Texas. The Hudnall-Pirtle site had at least one bone from a bison, and bison has been occasionally found in Middle and Late Caddo faunal assemblages in East Texas. 
In general, these Early Caddo groups had a diverse strategy of animal exploitation, sometimes emphasizing fish and turtle over larger game animals, but when large game animals were the focus of hunting activities, diets were either supplemented by fish, turtle, and/or small and medium-sized mammals. The use of fish or turtle may have had little to do with the location of sites with immediate access to large floodplain areas or apparent aquatic resources and more to do with dietary preferences and/or seasons of occupation, since these sites are situated in the uplands above small streams as well as on the banks of the Sabine and Red rivers, the largest streams in the region. 


\section{Chapter 7, Shell Analysis}

\section{Jesse Todd}

An examination of the shell material from sub-mound midden deposits in Unit N100 E110 (Lot 92) at the Mound Pond site (41HS12) in Harrison County, Texas, yielded little information mainly due to the shell's eroded and fragmented conditions and lack of diagnostic features. One left valve fragment, however, was identifiable based upon its pseudocardinal tooth. The fragment belongs to a Plectomerus dombeyanus, commonly called Bankclimber. Bankclimbers are well named due to the fact that they like to live on the banks of moderate to slow current streams. Bankclimbers can survive in a variety of environments except sand, but prefer mud to be present. The can live in ditches and lowland rivers (Howells et al. 1996:89). Mound Pond would be an ideal location for them since it is a "backwater" area from Big Cypress Bayou.

A shell fragment containing a sulcus was also found, but the shell could belong to Amblema plicata, Megalonaias nervosa, Plectomerus dombeyanus, and a few other species. 



\section{Chapter 8, Floral Remains from the 1977 Investigations at Mound Pond (41HS12)}

\section{Leslie L. Bush}

Twenty-one samples of carbonized plant material collected in 1977 were submitted for identification from the Mound Pond site. These samples came from both mound deposits and sub-mound midden deposits.

\section{Laboratory Methods}

Because charcoal from radiocarbon dating was to be chosen from the Mound Pond botanical material, radiocarbon protocols were followed for all samples. Samples were sorted on clean glassware and handled only with latex gloves. They were not screened, and contact with paper was avoided.

Each charcoal fragment was examined under a stereoscopic microscope at 7-28 X magnification for initial identification. For most lots in this study, genus identification was attempted for all wood charcoal fragments. For Lots 282 (N100 E104, level 6) and 337 (N100 E100, level 4, 50-65 cm), where wood charcoal was abundant, a sample of 20 specimens were selected at random for identification. As indicated below, Lots 282 and 337, therefore, included carbonized botanical remains that were identified as wood but were not further examined for genus and species identification. Wood charcoal fragments were snapped to reveal a transverse section and examined under a stereoscopic microscope at 28-180 X magnification. When necessary, tangential or radial sections were examined for ray seriation, presence of spiral thickenings, types and sizes of inter-vessel pitting, and other minute characteristics that can only be seen at the higher magnifications of this range.

Botanical materials were identified to the lowest possible taxonomic level by comparison to materials in the Macrobotanical Analysis comparative collection and through the use of standard reference works (Core et al. 1979; Davis 1993; Hoadley 1990; InsideWood 2004-onwards; Martin and Barkley 2000; Panshin and de Zeeuw 1980). Plant nomenclature follows that of the PLANTS Database (USDA, NRCS 2011).

Non-botanical materials in the samples were identified to class for examination by another specialist (Table 22). When identification was complete, weights were measured on an Ohaus Scout II 200 x $0.01 \mathrm{~g}$ electronic balance, counts were recorded, and all material was bagged and labeled for curation.

Table 22. Non-botanical items identified in carbon samples from the Mound Pond site (41HS12).

\begin{tabular}{llccl}
\hline Lot \# & Item & Count & Weight $(\mathbf{g})$ & Comments \\
\hline 005 & Ceramic & 1 & 0.80 & \\
014.1 & Fauna, tooth & 1 & 0.09 & deer \\
014.1 & Fauna, bone & & 0.90 & burned \\
036 & Petrified wood & 1 & 2.38 & \\
093 & Residue & & 8.20 & soil and charcoal flecks \\
101 & Soil/Ceramic/Daub & & 0.32 & \\
131 & Residue & 1.63 & soil and charcoal flecks \\
252 & Soil/Ceramic/Daub & 1.20 & \\
282 & Residue & & 14.57 & soil and charcoal flecks \\
282 & Soil & & 14.79 &
\end{tabular}


Table 22. Non-botanical items identified in carbon samples from the Mound Pond site (41HS12), cont.

\begin{tabular}{|c|c|c|c|c|}
\hline Lot \# & Item & Count & Weight (g) & Comments \\
\hline 337 & Residue & & 2.35 & soil and charcoal flecks \\
\hline 341 & Residue & & 0.33 & soil and charcoal flecks \\
\hline 353 & Soil/Ceramic/Daub & & 0.08 & \\
\hline
\end{tabular}

\section{Results}

Counts and weights of plants identified in the samples are given in Table 23. Examples of acorn nutmeat from Lot 93 (N100 E110, sub-mound midden deposits, $175 \mathrm{~cm}$ bs) are illustrated in Figure 40.

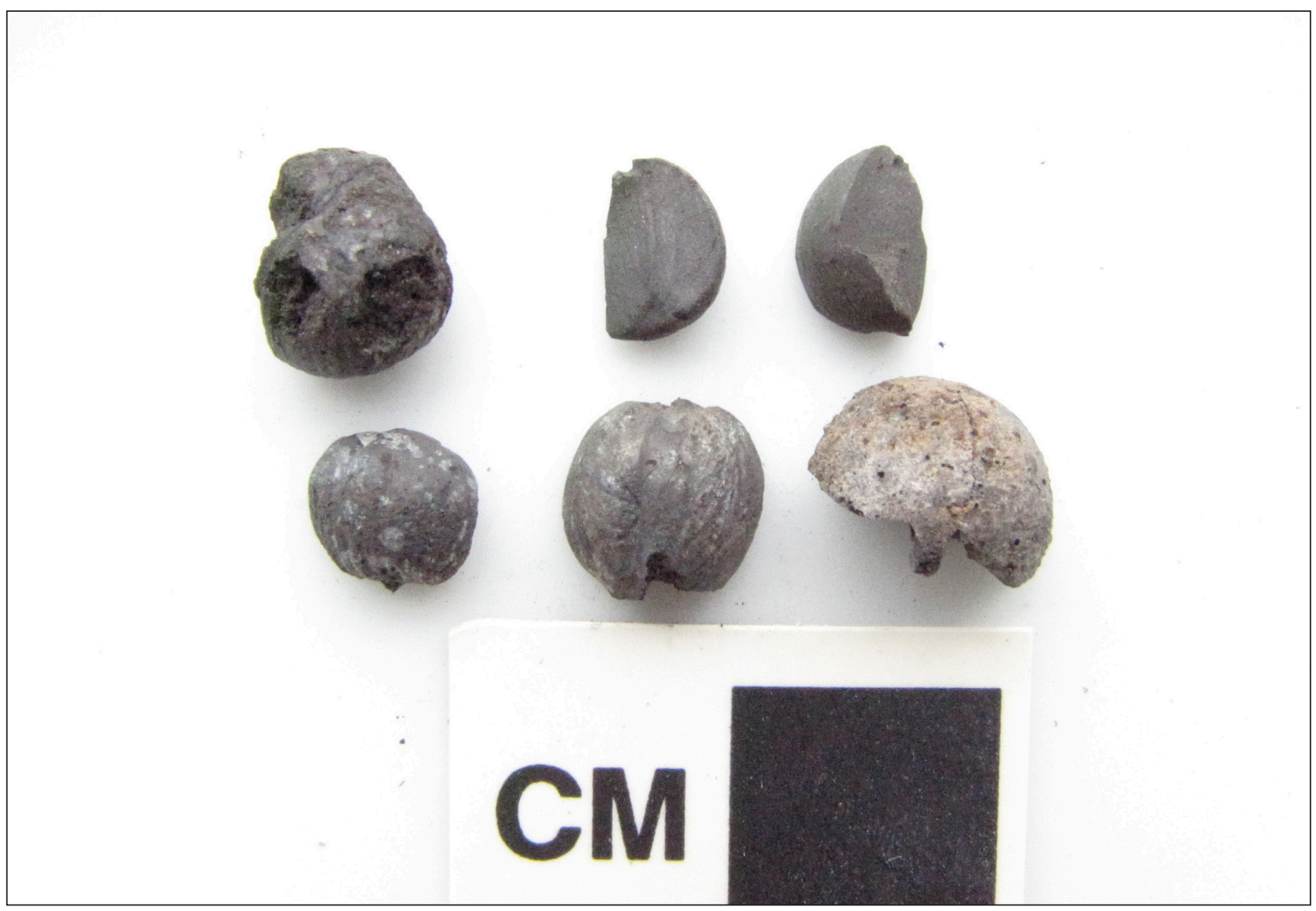

Figure 40. Acorn nut meat from Lot 93, N100 E110, sub-mound midden deposits, $175 \mathrm{~cm}$ bs.

\section{Discussion}

The sample size is small, but the plants recovered in the 1977 University of Texas investigations at Mound Pond are consistent with exploitation of upland or upland slope plant communities that would have occurred in the immediate vicinity of the Mound Pond site rather than riparian or wetland communities along Big Cypress Creek. 


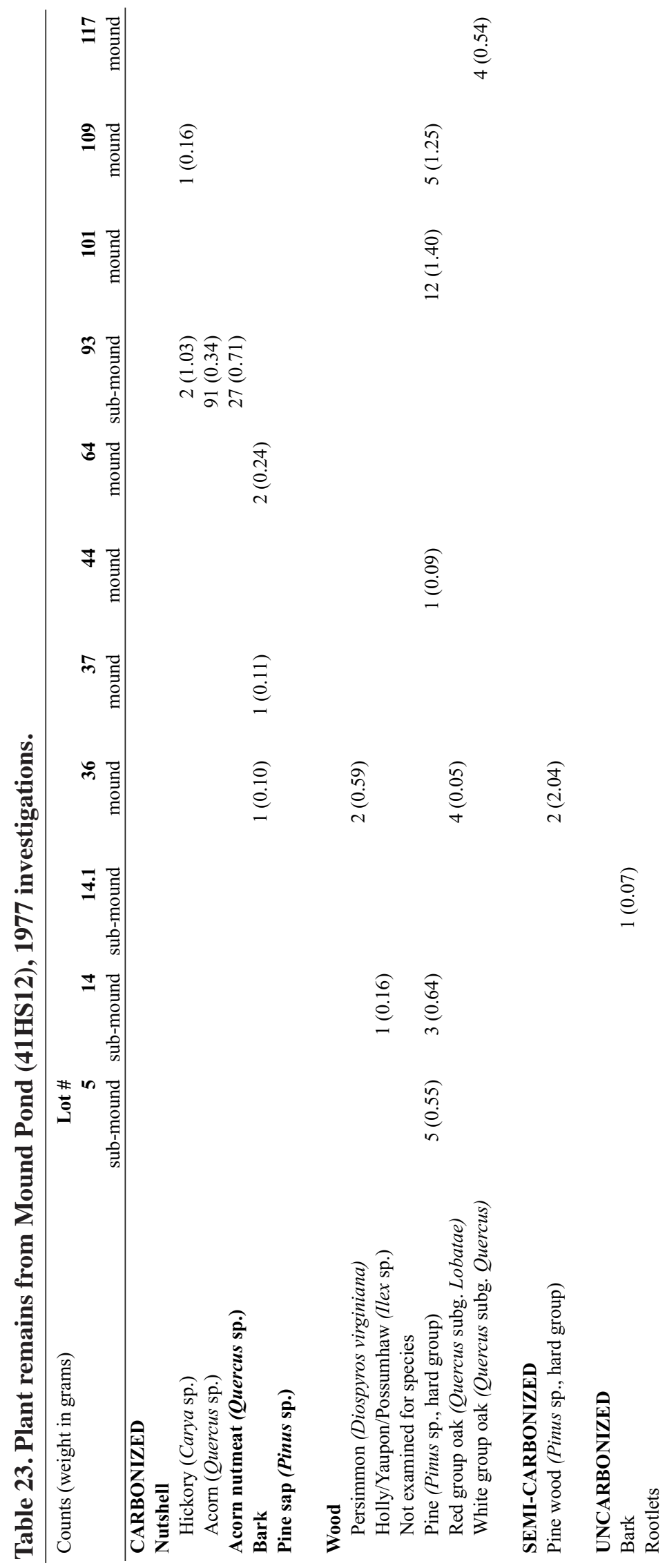




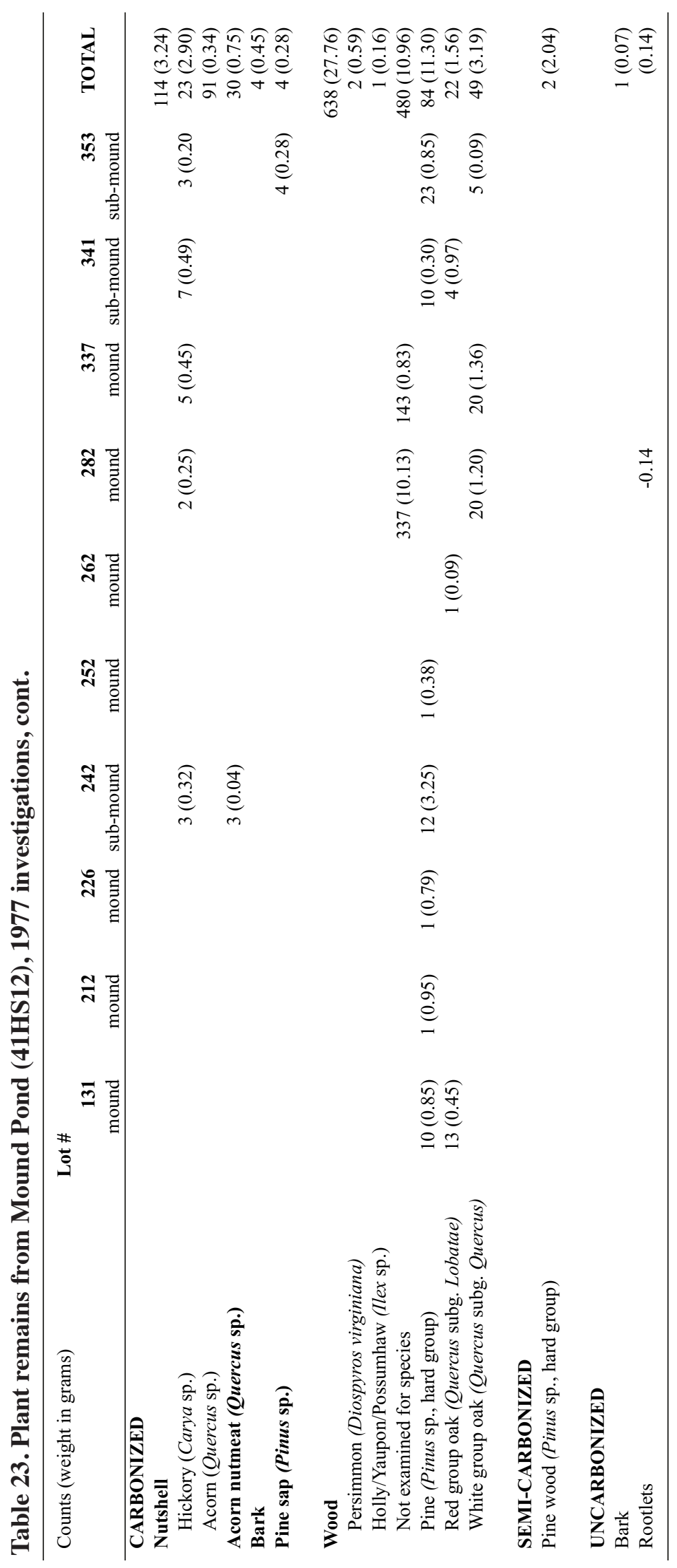


Nut mast is the only food plant debris represented in the floral remains. This is not surprising because nutshell is relatively large and tough, and it is likely to have been disposed of in a fire, which would also have contributed to its preservation on an archaeological site. The two types of nut resources represented at Mound Pond differ nutritionally. Hickory nutmeat is high in fat and contains more protein than most plant foods. Acorns are nutritionally more similar to grains such as corn in protein content than they are to hickory nuts (Table 24). Only sub-mound contexts contained acorn, but this may be the result of a small sample size rather than a difference in subsistence practices between earlier and later deposits. Otherwise, there is little difference between sub-mound and mound plant remains. No corn was present in either context.

Table 24. Proximate analysis of three edible tree nuts and corn meal per $100 \mathrm{~g}$ dry weight (USDA, ARS 2010).

\begin{tabular}{lccrr}
\hline & Hickory & Walnut & Acorn & $\begin{array}{c}\text { Yellow } \\
\text { Cornmeal }\end{array}$ \\
\hline Fat (g) & 64 & 59 & 31 & 4 \\
Protein (g) & 13 & 24 & 8 & 8 \\
Carbohydrate (g) & 18 & 10 & 53 & 77 \\
Water (g) & 2 & 5 & 5 & 4 \\
Energy (kcal) & 657 & 618 & 509 & 362 \\
\hline
\end{tabular}





\section{Chapter 9, Summary and Conclusions}

\section{Glenn T. Goode and Timothy K. Perttula}

Excavations conducted at the Mound Pond Site during July 1977 produced a substantial quantity of both ceramic and lithic artifacts, as well as various botanical and faunal remains. Several radiocarbon dates place the major activity at the site between the late 10th century and the early 13th century A.D. With the exception of a single test pit in Area B-50 m southwest of the mound-all of the excavations occurred within the mound, just beyond its east and west perimeters, and below the mound.

The flat-topped mound partially excavated at Mound Pond was of modest dimensions, being approximately $30 \mathrm{~m}$ in diameter and $1.85 \mathrm{~m}$ in height. It was constructed in three stages over a structure that was built at ground level, and then burned as apparently dictated by some significant but unknown event. The most numerous distinctive artifacts of this first occupation, found mostly in a dense midden deposit, are ceramics that Clarence Webb described in 1977 as being representative of the "Coles Creek Culture." It was his thinking that this earliest ceramic component possibly meant that Mound Pond was an outlier of the "Coles Creek Culture," rather than being a component of "Caddoan" affiliation. However, the radiocarbon dates from Mound Pond and certain Caddo ceramics in the sub-mound midden would seem to argue against this premise.

Precise cultural affiliation aside, it is clear that the original mound builders departed and were not immediately replaced at the site. This appears to be the case because the sandy mound (Stage 1) placed over the burned structure sat there unattended for an unknown period of time; however, hiatus on mound construction or use does not necessarily imply that the site was abandoned. Evidence of inactivity on the mound is seen in mound disfiguration and in the deposits of erosional wash that accumulated along its margins. This first mound was not capped with clay.

The next inhabitants at the site made and used typical Caddo ceramics. These Caddo enlarged the mound (Stage 2) by adding on to sandy Stage 1 at its highest points and expanding the diameter significantly, first with a clay lens - that was left to erode for a while - and then a sandy cap to top it off. Having expanded the flat, highest part significantly, the Caddo then apparently placed a structure of some sort on it: a post hole in the East Trench is believed to be evidence of the first structure on the mound.

The final stage of mound building (Stage 3) consisted of adding alternating layers of clay and sand, and sometimes mixed layers, that were relatively level in the mound's central portion, but became mixed and difficult to follow on the flanks. Perhaps as many as four separate additions of clay, followed by sand, were applied; but only from the last addition was a post hole, indicative of a structure, detected. And nowhere was there any evidence that a structure was burned on the mound.

The only apparent evidence of modern disturbances to the mound was a pothole at mound center. It was less than $2 \times 2 \mathrm{~m}$ in size, became smaller with depth, such that the final delving into the sub-mound deposit was apparently done with posthole diggers.

The mound vs. sub-mound midden deposits have distinctive ceramic assemblages, with a particular abundance of Coles Creek Incised sherds from the sub-mound deposits (cf. Story 1990a), although the available radiocarbon dates from the site indicate that there is not that much of a temporal difference between the two. As part of our work, we obtained 2-sigma calibrated age ranges for two samples of charred Carya sp. nutshells from sub-mound midden deposits. They range from A.D. 1030-1220, with 
calibrated intercepts at A.D. 1050, A.D. 1090, A.D. 1130, A.D. 1140, and A.D. 1170. These calibrated age ranges fall squarely in the Early Caddo period (ca. A.D. 1000-1200). The mean of the conventional ages for all four radiocarbon samples (from sub-midden deposits and sub-mound floor deposits) from the Mound Pond site is $920 \pm 35$ B.P. (A.D. $1030 \pm 35$ ). The IntCal09 calibration of the averaged dates at the 2-sigma age range is A.D. 1024-1212. OxCal v4.1.7 calibrations at 2-sigma for the two most recent Mound Pond dates have age ranges that extend from A.D. 1025-1221. The principal peaks in probability for both calibrated dates range from A.D. 1025-1169 and A.D. 1150-1220.

A large assemblage of ceramic sherds $(n=3063)$ was recovered from the mound and sub-mound midden deposits. The midden deposits under the mound are dominated by sherds from incised vessels, many of the Coles Creek Incised type, as well as sherds from vessels with incised lines and impressed triangles (also Coles Creek Incised), and a few engraved, pinched, punctated, and incised-punctated vessel sherds. At the Mounds Plantation site, in pre-A.D. 1050 archaeological deposits, sherds of Coles Creek Incised comprise between 91.6-100 percent of the decorated sherds, not much different than in the sub-mound midden deposits at the Mound Pond site. At the James Pace site (with median calibrated ages of A.D. 780 and A.D. 1010), Coles Creek Incised pottery accounts for 72 percent of the decorated sherds (Story 1990a:Table 77).

Incised sherds remain common in both the Mound and Area B assemblages, but with few Coles Creek Incised vessel sherds. More common in these two assemblages, which both date sometime later than the sub-mound midden deposit, are incised-punctated, punctated, band punctated, engraved, and slipped sherds. Similar decorated sherd assemblages have been dated to as late as cal A.D. 1260 at the Boxed Springs site (41UR30), but engraved sherds constitute 35 percent of the decorated sherd assemblage there. At Mound Pond, only 8.7 percent of the decorated sherds are from engraved and/or slipped fine ware vessels. Engraved pottery at the Mounds Plantation site are found in contexts that have calibrated radiocarbon age ranges of A.D. 989-1257. In sherd assemblages they account for no more than 7.9-22 percent of the decorated sherds, quite comparable to the Mound Pond assemblage. In other Northwest Louisiana ceramic assemblages, and the Crenshaw site, fine wares are not common before cal A.D. 1000, and even after that date, engraved wares are not as well represented in these sites compared to contemporaneous East Texas Caddo sites; Mound Pond is an important exception when it comes to the use of engraved wares.

It is fair to state that the ceramic assemblages from the sub-mound midden and mound deposits at the Mound Pond site are culturally distinctive, particularly when it is considered that there are 11th and 12th century A.D. radiocarbon dates that have been obtained from the sub-mound midden deposits. The sub-mound midden deposits are defined by the high frequencies of horizontal incised vessels, many of them identified as several varieties of Coles Creek Incised. Very similar Northwest Louisiana ceramic assemblages appear to date one or two generations earlier, namely from the late 10th century to the mid11th century. The ceramics from the mound deposits at Mound Pond resemble Early Caddo assemblages from both East Texas and Northwest Louisiana, with a considerable number of incised, punctated, and incised-punctated vessel sherds, and relatively low frequencies of engraved fine ware sherds. Given the stratigraphic position of the mound deposits relative to the sub-mound midden deposits - in combination with the calibrated ages of the sub-mound midden radiocarbon dates - the mound ceramics at Mound Pond apparently date as late as the early years of the 13th century A.D.

In comparing the technological character of the mound vs. sub-mound midden ceramic assemblages, grog temper was the preferred temper inclusion in the decorated sherds in both ceramic assemblages, although its use is more common in the sub-mound midden deposits. This was also the case in the plain wares from both contexts. Crushed pieces of burned bone and hematite were also used as tempering 
materials, particularly in the mound deposits. Bone temper was much more abundant in the plain wares from the mound deposits compared to the plain wares in the sub-mound midden deposits, and this is also the case with the decorated vessel sherds. Data on the firing conditions observed in the decorated sherds from both mound and sub-mound midden contexts indicate that they are from vessels most commonly fired in a reducing or low oxygen environment: 80 percent in the mound deposits, and 85.8 percent in the sub-mound midden deposits. In the plain wares, between 62.0-72.9 percent of the sherds are from vessels fired in a reducing environment. Vessels fired in an oxidizing environment are not common in the Mound Pond ceramic assemblages, either in the plain sherds (6.9-13.3 percent) or in the decorated sherds (7.113.3 percent). However, sherds from incompletely oxidized vessels are much more common in the plain wares, regardless of context, than is the case among the decorated wares. Finally, sherds from sooted, smudged, or reheated vessels are more common among the decorated wares than they are among the plain wares. These differences in firing conditions between the mound and sub-mound midden deposits, and between the plain and decorated wares, likely relates to the differences through time in the intended functions and uses of the Mound Pond ceramic wares for cooking, food serving, and as containers for liquids. The decorated sherds from the Mound Pond site are thickest in the sub-mound midden assemblage than they are in the overlying mound deposits, most notably in the rim sherds. The rim sherds in the submound midden have a mean thickness of $7.59 \mathrm{~mm}$, compared to $6.88 \mathrm{~mm}$ in the mound assemblage. The decorated rim sherds are from thicker vessels than the plain wares $(6.2-6.7 \mathrm{~mm})$ in both assemblages. Decorated body sherds in the mound and sub-mound midden assemblages are virtually the same thickness: $6.87 \mathrm{~mm}$ (mound) and $6.89 \mathrm{~mm}$ (sub-mound midden).

The assemblage of lithic tools and debitage from Mound Pond consists of approximately 1500 specimens. The great majority of this material is debitage, and it is primarily the debitage of siliceous pebbles from local and regional sources. Red River Jasper is the dominant material, the majority of it believed to have been acquired from the Red River drainage approximately $30 \mathrm{~km}$ to the east. Much smaller samples of most of the lithic resources common to Northeast Texas occur at the site, as well as only one or two specimens of much more distant resources such as novaculite and Central Texas flint.

Another important feature of the lithic assemblage is the overall small size of the artifacts, a feature directly related to the small size of the available resources. Chipping such materials is a challenge, and one that frequently required using a hammer-anvil, direct-percussion, technology that often involves more luck than skill to be successful; the Mound Pond knappers were not lucky nearly as often as they would have liked. They also frequently used the more standard hard and soft-hammer methods for making flake blanks and small bifaces, and the pressure-flaking method to finish certain of their small formal tools such as arrow points.

The sample of stone tools is approximately 7 percent of the total lithic artifact sample, with the most common tool form being the arrow point; blanks and preforms (mostly failures) also contribute to the overall arrow point-related assemblage. Among the identified arrow points are several of the types common to the Early Caddo period, including Friley, Alba, Bonham, and Colbert. Also in the projectile point category are three dart points, but there is no detectable evidence that the Caddo made them. If not left at Mound Pond by Archaic inhabitants, then they most likely were brought in by the Caddo for purposes other than projectile points. Other siliceous stone tools, very few in number, include utilized flakes and trimmed flakes for use in minor cutting and scraping tasks, small biface fragments of unknown purpose, and possible gravers. In the category of ground, battered, and polished tools there is a possible axe fragment, two small hammerstones, and small numbers of pitted stones and grinding slab fragments. In sum, the overall character of the lithic artifact assemblage at Mound Pond, then, is typical in every way of Early Caddo occupations of the region. 
Despite the findings from the investigations reported on herein, the Mound Pond site (41HS12) still remains poorly known, and the non-mound archaeological deposits at the site warrant study to assess their material culture character relative to the mound and sub-mound midden deposits in the mound itself, and to determine the nature of features and occupational remains in those deposits. Also sorely needed is the comprehensive radiocarbon dating from key contexts in the site's archaeological deposits of charred plant remains, ceramic residues, and organic residues incorporated in the paste of ceramic sherds to definitively establish the age of the village deposits at Mound Pond, as well as the sub-mound midden deposits, and the mound deposits and its structural features. Hopefully, there will be future archaeological investigations at this important East Texas Caddo mound center. 


\section{End Notes}

1. The specimen inventory recorded by students at TARL lists the following lithic artifacts that, for the most part, could not be found for the present analysis. According to the inventory, at least 1411 specimens of lithic debitage were recovered, compared to the 522 discussed in the present analysis.

In the way of tools, preforms, and failures, the following totals represent that recovered sample as best as possible, with the main problem being the inexperience of the cataloguers, inexperience in identifying tools, etc: dart points ( $n=3$ unidentified); arrow points $(n=27)$; the following identifications were made: Friley ( $n=3)$; Colbert $(n=4)$; Alba $(n=2)$; Alba/Bonham $(n=5)$; Hayes-like $(n=1)$; unidentified $(n=12)$; arrow point performs $(\mathrm{n}=4$; it is likely that some unidentified arrow points are in fact preforms); lithic points $(n=18)$, no additional information as to what kinds of points; bifaces $(n=14)$, the only additional information on these tools is that one biface is novaculite; some of these are biface fragments, and it is likely that some, probably most, were not completed tools); preforms/blanks $(n=3)$; perforators $(n=2)$; and unifaces/utilized flakes $(\mathrm{n}=6)$.

Although missing, this modest sample of chipped stone tools at least provides certain basic information regarding the kinds and quantities of tools used at this mound and habitation site. Only three dart points indicates that there was not a significant Archaic presence there; chances are that if these dart points were not made and used by the Caddo inhabitants, then they were at least collected and brought there by Caddo people. The most numerous tools are arrow points, and the several types present are among the most common in the region in pre-A.D. 1300 contexts. The other tools, blanks, and preforms indicate that a diverse but typical range of activities involving both chipped stone and ground stone tools occurred at Mound Pond.

2. Six historic artifacts postdating ca. 1890 were found during the archaeological investigations in the upper levels of the mound at the Mound Pond site. These included a post-1890 wire nail (N100 E104, 0-20 $\mathrm{cm}$ bs), a .22 cal bullet (N100 E102, 35-50 cm bs), two small pieces of lead (either slag or sprue, N110 E118, level 1), a fragmented lead bullet (N100 E108, level 2), and two pieces of coal (N100 E133, 0-15 cm bs). 



\section{References Cited}

Arnold, D. E.

2000 Does the Standardization of Ceramic Pastes Really Mean Specialization? Journal of Archaeological Method and Theory 7:333-375.

Arthur, J. W.

2006 Living with Pottery: Ethnoarchaeology among the Gamo of Southwest Ethiopia. The University of Utah Press, Salt Lake City.

Banks, L. D.

1990 From Mountain Peaks to Alligator Stomachs: A Review of Lithic Sources in the Trans-Mississippi South, the Southern Plains, and Adjacent Southwest. Memoir No. 4. Oklahoma Anthropological Society, Norman.

Bezanson, D.

2000 Natural Vegetation Types of Texas and their Representation in Conservation Areas. Master's thesis, Department of Geography, University of Texas at Austin

Bradley, R. S., K. R. Briffa, J. Cole, M. K. Hughes, and T. J. Osburn

2003 The Climate of the Last Millennium. In Paleoclimate, Global Change and the Future, edited by K. D. Alverson, R. S. Bradley, and T. F. Pedersen, pp. 105-141. Springer-Verlag, Berlin.

Brewington, R. L., J. E. Dockall, and H. J. Shafer

1995 Archaeology of 41MX5: A Late Prehistoric Caddoan Hamlet in Morris County, Texas. Report of Investigations No. 1., Center for Environmental Archaeology, Texas A \& M University, College Station.

Brown, I. W.

1998 Decorated Pottery of the Lower Mississippi Valley: A Sorting Manual. Mississippi Archaeological Association and Mississippi Department of Archives and History, Jackson.

Brown, K. M.

1976 Fused Volcanic Glass from the Manning Formation. Bulletin of the Texas Archeological Society 47: 189-207.

Bruseth, J. E.

1991 Hudnall-Pirtle Site: An Early Caddoan Mound Complex in Northeast Texas. Caddoan Archeology Newsletter 2(3):9-15.

1998 The Development of Caddoan Polities along the Middle Red River Valley of Eastern Texas and Oklahoma. In The Native History of the Caddo: Their Place in Southeastern Archeology and Ethnohistory, edited by T. K. Perttula and J. E. Bruseth, pp. 47-68. Studies in Archeology 30. Texas Archeological Research Laboratory, The University of Texas at Austin.

Bruseth, J. E. and T. K. Perttula

1981 Prehistoric Settlement Patterns at Lake Fork Reservoir. Texas Antiquities Permit Series, Report No. 2. Texas Antiquities Committee and Southern Methodist University, Austin and Dallas. 
2006 Archeological Investigations at the Hudnall-Pirtle Site (41RK4): An Early Caddo Mound Center in Northeast Texas. Caddo Archeological Journal 15:57-158.

Corbin, J. E. and J. P. Hart

1998 The Washington Square Mound Site: A Middle Caddo Mound Complex in South Central East Texas. Bulletin of the Texas Archeological Society 69:47-78.

Core, H. A., W. A. Cote and A. C. Day

1979 Wood Structure and Identification. 2nd edition. Syracuse University Press, Syracuse, New York.

Creel, D. G., D. Hudler, S. M. Wilson, T. C. Schultz, and C. P. Walker

2005 A Magnetometer Survey of Caddoan Mounds State Historic Site. Technical Report 51. Texas Archeological Research Laboratory, The University of Texas at Austin.

Dahmer, F.

1995 Caddo was --: A Short History of Caddo Lake. University of Texas Press, Austin.

Davidson, B.

1997 Appendix 2: Preliminary Study of the Faunal Remains from the George C. Davis Site, 1968-1970 Excavations. Bulletin of the Texas Archeological Society 68:108-111.

Davis, L. W.

1993 Weed Seeds of the Great Plains: A Handbook for Identification. University Press of Kansas, Lawrence.

Davis, W. B.

1978 The Mammals of Texas. Bulletin No. 41, revised. Texas Parks and Wildlife Department, Austin.

Diggs Jr., G. M., B. L. Lipscomb, M. D. Reed and R. J. O'Kennon

2006 Illustrated Flora of East Texas, Volume One: Introduction, Pteridophytes, Gymnosperms, and Monocotyledons. Sida, Botanical Miscellany, No. 26. Botanical Research Institute of Texas, Fort Worth.

Dowd, E. L.

2011 Sourcing Red River Jasper: An Archeological and Geological Investigation of a Gravel Chert in the Red River Drainage. Caddo Archeology Journal 21:89-106.

Emerson, T. E. and J. S. Girard

2004 Dating Gahagan and Its Implications for Understanding Cahokia-Caddo Interactions. Southeastern Archaeology 23(1):57-64.

Fields, R. C. and E. F. Gadus (editors)

2012 Archeology of the Nadaco Caddo: The View from the Pine Tree Mound Site (41HS15), Harrison County, Texas. 2 Vols. Report of Investigations No. 164. Prewitt and Associates, Inc., Austin.

Girard, J. S.

1992 Regional Archaeology Program, Management Unit 1: Third Annual Report. Northwestern State University, Natchitoches. 
1994 Investigations at the James Pace Site (16DS268), De Soto Parish, Louisiana. Caddoan Archeology Newsletter V(1):8-16.

1997 Caddoan Settlement in the Red River Floodplain: Perspectives from the Willow Chute Bayou Area, Bossier Parish, Louisiana. Louisiana Archaeology 22:143-162.

2009a Regional Archaeology Program Management Unit 1, Twentieth Annual Report. Northwestern State University of Louisiana, Natchitoches. Report on file with the Louisiana Division of Archaeology, Department of Culture, Recreation and Tourism, Baton Rouge.

2009b Comments on Caddo Origins in Northwest Louisiana. Journal of Northeast Texas Archaeology 31:51-60.

2012 Recent Investigations at the Mounds Plantation Site (16CD12), Caddo Parish, Louisiana. Caddo Archeology Journal 22:21-62.

2014 The James Pace Site (16DS268) and Early Caddo Developments Along the Upper Sabine River. Bulletin of the Texas Archeological Society 85:61-81.

Goode, G. T.

2002 The Anthon Site: A Prehistoric Encampment in Southern Uvalde County, Texas. Report 38. Texas Department of Transportation, Environmental Affairs Division, Archeological Studies Program, Austin.

Goodyear, A. C.

1974 The Brand Site: A Techo-Functional Study of a Dalton Site in Northeastern Arkansas. Research Series 7. Arkansas Archeological Survey, Fayetteville.

Gow, J. E.

1905 An Ecological Study of the Sabine and Neches Valleys, Texas. Proceedings of the Iowa Academy of Sciences 12:39-50.

Hamilton, D. L.

1997 Observations on Caddoan Burial Practices at the Sanders Site (41LR2). Bulletin of the Texas Archeological Society 68:115-134.

Hayden, B.

1980 Confusion in the Bipolar World: Bashed Pebbles and Splintered Pieces. Lithic Technology 9:2-7.

Hoadley, R. B.

1990 Identifying Wood: Accurate Results with Simple Tools. The Taunton Press, Newtown, Connecticut.

Howells, R. G., R. W. Neck and H. D. Murray

1996 Freshwater Mussels of Texas. Inland Fisheries Division, Texas Parks and Wildlife Department, Austin.

Hunter, D. G., C. E. Pearson, J. LeBoeuf, and D. B. Kelley

2002 Cultural Resources Evaluations of the T.C. Bearden (16NA494), Ramblin Wreck (16NA495), and Charles Webb (16RR86) Archaeological Sites, Located Along Red River in Natchitoches and Red River Parishes, Louisiana. Coastal Environments, Inc., Baton Rouge. 
InsideWood

2004-onwards Published on the Internet. http://insidewood.lib.ncsu.edu/search. Accessed May 6, 2011.

Jackson, J. M.

1981 Floral and Faunal Remains. In Archeological Investigations at the George C. Davis Site, Cherokee County, Texas: Summers of 1979 and 1980, edited by D. A. Story, pp. 347-360. Occasional Papers No. 1. Texas Archeological Research Laboratory, The University of Texas at Austin.

Leudtke, B. E.

1992 An Archaeologist's Guide to Chert and Flint. Archaeological Research Tools 7. Institute of Archaeology, University of California, Los Angeles.

Luke, C. J.

1978 The Marshall Powder Mill Site. Publications in Archeology Report 11. Texas Department of Highways and Public Transportation, Highway Design Division, Austin.

Malof, A. F., D. J. Prikryl, and G. T. Goode

2007 Excavations at 41CM25, Comal Power Plant Redevelopment Project, Comal County, Texas. Cultural Resources Report No. 12. Lower Colorado River Authority, Austin.

Martin, A. C. and W. D. Barkley

2000 Seed Identification Manual. The Blackburn Press, Caldwell, New Jersey

McGimsey, C. R. and J. van der Koogh

2001 Louisiana's Archaeological Radiometric Database. Special Publication No. 3. Louisiana Archaeological Society, Baton Rouge.

Panshin, A. J. and C. de Zeeuw

1980 Textbook of Wood Technology: Structure, Identification, Properties, and Uses of the Commercial Woods of the United States and Canada. Fourth edition. McGraw-Hill Book Company, New York.

Perttula, T. K.

1993 The Development of Agriculture in Northeast Texas before A.D. 1600. In Archeology in the Eastern Planning Region, Texas: A Planning Document, edited by N. A. Kenmotsu and T. K. Perttula, pp. 121-146. Cultural Resource Management Report 3. Department of Antiquities Protection, Texas Historical Commission, Austin.

2007 Upper Neches River Basin Caddo Ceramics, an Attempt at an Updated Seriation and a Context for Understanding Frankston to Allen Phase Ceramic Stylistic and Technological Changes. Journal of Northeast Texas Archaeology 26:154-158.

2008b Trends and Varieties in Late Caddo and Historic Caddo Fine Ware Pottery Types in the Upper Neches River Basin. Journal of Northeast Texas Archaeology 28:51-55.

2008c Caddo Agriculture on the Western Frontier of the Eastern Woodlands. Plains Anthropologist 53(205):79-105. 
2010 Woodland and Caddo Ceramic Traditions in East Texas. In Regional Summaries of Prehistoric and Early Historic Ceramics in Texas for the Council of Texas Archeologists, assembled and edited by L. W. Ellis and T. K. Perttula, pp. 13-41. CTA Ceramics Protocol Committee, Austin accessed on June 8, 2011, at http://www.counciloftexasarcheologists.org/index.php?option=com_content\&task= view\&id=87\&ltemid $=94$

2011a Another Look at the Grace Creek \#1 Site in Gregg County, Texas, as Seen Through Ceramic Analysis. Journal of Northeast Texas Archaeology 35:11-45.

2011b Analysis of the Ceramic Artifacts from the Boxed Springs Site. In Archaeological and Archaeogeophysical Investigations at an Early Caddo Mound Center in the Sabine River Basin of East Texas, assembled by T. K. Perttula, pp. 47-77. Special Publication No. 15. Friends of Northeast Texas Archaeology, Austin and Pittsburg.

Perttula, T. K. (assembler)

2011 (assembler) Archaeological and Archaeogeophysical Investigations at an Early Caddo Mound Center in the Sabine River Basin of East Texas, Special Publication No. 15. Friends of Northeast Texas Archaeology, Austin and Pittsburg.

Perttula, T. K. (editor)

2005 Archeological Investigations at the Pilgrim's Pride Site (41CP304), a Titus Phase Community in the Big Cypress Creek Basin. 2 Vols. Report of Investigations No. 30. Archeological \& Environmental Consultants, LLC, Austin.

2008a Lake Naconiche Archeology, Nacogdoches County, Texas: Results of the Data Recovery Excavations at Five Prehistoric Archeological Sites. 2 Vols. Report of Investigations No. 60. Archeological \& Environmental Consultants, LLC, Austin.

Perttula, T. K. and B. Nelson

2003 The Nawi haia ina Site (41RK170): Archeological Investigations in the City of Henderson's Southside Wastewater Treatment Plant, Rusk County, Texas. Report of Investigations No. 51. Archeological \& Environmental Consultants, LLC, Austin.

2004 Woodland and Caddo Archeology at the Broadway or Kanduts'ah Kuhnihdahahdisa' Site (41SM273) on the City of Tyler-Lake Palestine WTP Project, Smith County, Texas. Report of Investigations No. 50. Archeological \& Environmental Consultants, LLC, Austin.

2011 Archeological Investigations of the Proposed University East Approach Road In the City of Texarkana and Bowie County, Texas. Report of Investigations No. 118. Archeological \& Environmental Consultants, LLC, Austin.

Perttula, T. K. and D. E. Wilson, with contributions by M. Walters

2000 An Early Caddoan Period Cremation from the Boxed Springs Mound Site (41UR30) in Upshur County, Texas, and a Report on Previous Archaeological Investigations. Journal of Northeast Texas Archaeology 12:31-71.

Phillips, P.

1970 Archaeological Survey in the Lower Yazoo Basin, Mississippi, 1949-1955. 2 Parts, Papers Volume 60. Peabody Museum of Archaeology and Ethnology, Harvard University, Cambridge. 
Reimer, P. J., M. G. L. Baillie, E. Bard, A. Bayliss, J. W. Beck, P. G. Blackwell, C. Bronk Ramsey, C. E. Buck, G. S. Burr, R. L. Edwards, M. Friedrich, P. M. Grootes, T. P. Guilderson, I. Hajdas, T. J. Heaton, A. G. Hogg, K. A. Hughen, K. F. Kaiser, B. Kromer, F. G. McCormac, S. W. Manning, R. W. Reimer, D. A. Richards, J. R. Southon, S. Talamo, C. S. M. Turney, J. van der Plicht, and C. E. Weyhenmeyer

2009 IntCal09 and Marine09 radiocarbon age calibration curves, 0-50,000 years cal BP. Radiocarbon 51(4):1111-1150.

Rice, P. M.

1996 Recent Ceramic Analysis: 1. Function, Style, and Origins. Journal of Archaeological Research 4(2):133-163.

Schniebs, L.

2008 Faunal Analyses. In Lake Naconiche Archeology, Nacogdoches County, Texas: Results of the Data Recovery Excavations at Five Prehistoric Archeological Sites, edited by T. K. Perttula, pp. 581-610. Report of Investigations No. 60. 2 Vols. Archeological \& Environmental Consultants, LLC, Austin.

2011 Analysis of Faunal Remains from the Boxed Springs Site (41UR30): An Early Caddo Mound Center in Upshur County, Texas. In Archaeological and Archaeogeophysical Investigations at an Early Caddo Mound Center in the Sabine River Basin of East Texas, assembled by T. K. Perttula, pp. 147-150. Special Publication No. 15. Friends of Northeast Texas Archaeology, Pittsburg and Austin.

Shafer, H. J.

1973 Lithic Technology at the George C. Davis Site, Cherokee County, Texas. Ph.D. dissertation, Department of Anthropology, The University of Texas At Austin.

2011 Comparing the Boxed Springs Lithics to Other Early Caddo Sites. In Archaeological and Archaeogeophysical Investigations at an Early Caddo Mound Center in the Sabine River Basin of East Texas, assembled by T. K. Perttula, pp. 112-137. Special Publication No. 15. Friends of Northeast Texas Archaeology, Austin and Pittsburg.

Story, D. A.

1990a Excavated Caddoan Sites with Coles Creek Style Ceramics. In The Archeology and Bioarcheology of the Gulf Coastal Plain, by D. A. Story, J. A Guy, B. A. Burnett, M. D. Freeman, J. C. Rose, D. G. Steele, B. W. Olive, and K. J. Reinhard, pp. 736-748. Research Series No. 38. 2 Vols. Arkansas Archeological Survey, Fayetteville.

1990b Cultural History of the Native Americans. In The Archeology and Bioarcheology of the Gulf Coastal Plain, by D. A. Story, J. A Guy, B. A. Burnett, M. D. Freeman, J. C. Rose, D. G. Steele, B. W. Olive, and K. J. Reinhard, pp. 163-366. Research Series No. 38. 2 Vols. Arkansas Archeological Survey, Fayetteville.

1997 1968-1970 Archeological Investigations at the George C. Davis Site, Cherokee County, Texas. Bulletin of the Texas Archeological Society 68:1-113.

1998 The George C. Davis Site: Glimpses into Early Caddoan Symbolism and Ideology. In The Native History of the Caddo: Their Place in Southeastern Archeology and Ethnohistory, edited by T. K. Perttula and J. E. Bruseth, pp. 9-43. Studies in Archeology 30. Texas Archeological Research Laboratory The University of Texas at Austin. 
2000 Introduction. In The George C. Davis Site, Cherokee County, Texas, by H. P. Newell and A. D. Krieger, pp. 1-31. 2nd Edition. Society for American Archaeology, Washington, D.C.

Story, D. A. (editor)

1981 Archeological Investigations at the George C. Davis Site, Cherokee County, Texas: Summers 1979 and 1980. Occasional Papers, Vol. 1. Texas Archeological Research Laboratory, The University of Texas at Austin.

Suhm, D. A. and E. B. Jelks (editors)

1962 Handbook of Texas Archeology: Type Descriptions. Special Publication No. 1, Texas Archeological Society, and Bulletin No. 4, Texas Memorial Museum, Austin.

Teltser, P. A.

1993 An Analytic Strategy for Studying Assemblage-Scale Ceramic Variation: A Case Study from Southeast Missouri. American Antiquity 58(3):530-543.

Thurmond, J. P.

1990 Archeology of the Cypress Creek Drainage Basin, Northeastern Texas and Northwestern Louisiana. Studies in Archeology 5. Texas Archeological Research Laboratory, The University of Texas at Austin.

Trubitt, M. B.

2009 Burning and Burying Buildings: Exploring Variation in Caddo Architecture in Southwest Arkansas. Southeastern Archaeology 28(2):233-247.

USDA, ARS (United States Department of Agriculture, Agricultural Research Service)

2010 USDA National Nutrient Database for Standard Reference. Release 23. http://www.ars.usda.gov/ba/ bhnrc/ndl. Accessed May 12, 2011.

USDA, NRCS (United States Department of Agriculture, Natural Resources Conservation Service)

2011 The PLANTS Database. http://plants.usda.gov. National Plant Data Center, Baton Rouge, Louisiana 70874-4490. Accessed May 10, 2011.

Viau, A. E., K. Gajewski, P. Fines, D. E. Atkinson, and M. C. Sawada

2002 Widespread Evidence of 1500 yr Climatic Variability in North America during the Past 14,000 yr. Geology 30:455-458.

Walker, C. P.

2009 Landscape Archaeogeophysics: A Study of Magnetometer Surveys from Etowah (9BW1), The George C. Davis Site (41CE19), and the Hill Farm Site (41BW169). Ph.D. Dissertation, Department of Anthropology, The University of Texas at Austin.

Walters, M. and T. K. Perttula

2010 The Holmes Site (41SM282): An East Texas Site with Lower Mississippi Valley Ceramic Sherds. Louisiana Archaeology 31:34-42.

Webb, C. H.

1963 The Smithport Landing Site: An Alto Focus Component in DeSoto Parish, Louisiana. Bulletin of the Texas Archeological Society 34:143-187. 
Webb, C. H., and M. Dodd, Jr.

1939 Further Excavations of the Gahagan Mound: Connections with a Florida Culture. Bulletin of the Texas Archeological and Paleontological Society 11:92-126.

Webb, C. H. and R. R. McKinney

1963 An Unusual Pottery Vessel from Mounds Plantation, Caddo Parish, Louisiana. The Arkansas Archeologist 4(5):1-9.

1975 Mounds Plantation (16CD12), Caddo Parish, Louisiana. Louisiana Archaeology 2:39-127.

Webb,. C. H., F. E. Murphey, W.esley G. Ellis, and H. R. Green

1969 The Resch Site, 41HS16, Harrison County, Texas. Bulletin of the Texas Archeological Society 40: 3-106.

Wilson, D.

2012 Bioarchaeological Evidence of Subsistence Strategies among the East Texas Caddo. In The Archaeology of the Caddo, edited by T. K. Perttula and C. P. Walker, pp. 86-116. University of Nebraska Press, Lincoln.

Wilson, D. and T. K. Perttula

2013 Reconstructing the Diet of the Caddo through Stable Isotopes. American Antiquity 78(4):702-723.

Yates, B. C.

2006 The Faunal Remains from the Hudnall-Pirtle Site (41RK4). Caddo Archeology Journal 15:137-139.

Young, W. C.

1981 Test Excavations at the Tankersley Creek Site, Titus County, Texas. Publications in Archaeology No. 22. Texas State Department of Highways and Public Transportation, Austin. 


\section{Appendix 1, Lot Numbers and Proveniences, Mound Pond Site (41HS12)}

\begin{tabular}{|c|c|c|c|}
\hline Lot No. & Provenience & Level & Comments \\
\hline 001-005 & N97 E109 & - & Surface of trench floor \\
\hline 006-014 & N97 E109 & $1,0-5 \mathrm{~cm}$ & In trench floor \\
\hline 015-019 & N97 E109 & $2,5-10 \mathrm{~cm}$ & In trench floor \\
\hline $020-023$ & N97 E109 & $3,10-15 \mathrm{~cm}$ & In trench floor \\
\hline 024-029 & N97 E110 & $2,5-10 \mathrm{~cm}$ & In trench floor \\
\hline 030-038 & N110 E118 & 1 & From mound surface \\
\hline 039-044 & N110 E118 & $1 / 2,0-15 \mathrm{~cm}$ & From mound surface \\
\hline $045-49$ & Trench 4 & $0-20 \mathrm{~cm}$ & surface to clay cap \\
\hline $050-57$ & N95 E111 & $1,0-15 \mathrm{~cm}$ & Midden surface, trench floor \\
\hline $058-065$ & N97 E109-111 & - & from north wall to $1 \mathrm{~m}$ south \\
\hline $066-067$ & N100 E110 & $5,70-90 \mathrm{~cm}$ & From mound surface \\
\hline 068-069 & N100 E110 & $6,90-110 \mathrm{~cm}$ & From mound surface \\
\hline $070-074$ & N100 E110 & $7,110-130 \mathrm{~cm}$ & From mound surface \\
\hline $075-076$ & N100 E110 & $173 \mathrm{~cm}$ & Midden \\
\hline 077-085 & N100 E110 & $175 \mathrm{~cm}$ & Midden surface \\
\hline 086-094 & N100 E110 & - & Midden \\
\hline 095-101 & N95 E110 & $1,0-10 \mathrm{~cm}$ & In trench floor \\
\hline 102-109 & N95 E110 & $2,10-15 \mathrm{~cm}$ & In trench floor \\
\hline $110-116$ & N93 E115 & $1,0-10 \mathrm{~cm}$ & In trench floor \\
\hline $117-121$ & N95 E110 & $3,15-20 \mathrm{~cm}$ & In trench floor \\
\hline $122-123$ & N100 E112 & $2,20-35 \mathrm{~cm}$ & From mound surface \\
\hline $124-125$ & N100 E112 & $3,35-50 \mathrm{~cm}$ & From mound surface \\
\hline $126-127$ & N100 E112 & $4,50-60 \mathrm{~cm}$ & From mound surface \\
\hline $128-131$ & N100 E112 & $5,60-80 \mathrm{~cm}$ & From mound surface \\
\hline 132 & N100 E112 & $135 \mathrm{~cm}$ & From mound surface \\
\hline $134-136$ & N100 E112 & $138-150 \mathrm{~cm}$ & From mound surface \\
\hline $137-138$ & N100 E112 & $160 \mathrm{~cm}$ & Midden surface \\
\hline $139-141$ & N100 E112 & - & below midden floor \\
\hline $142-146$ & N100 E110 & $1,0-20 \mathrm{~cm}$ & From mound surface \\
\hline $147-152$ & N100 E108 & 2 & From mound surface \\
\hline $153-155$ & N100 E108 & $1,0-20 \mathrm{~cm}$ & From mound surface \\
\hline $156-162$ & N100 E133 & $2,15-30$ & From mound surface \\
\hline
\end{tabular}




\begin{tabular}{|c|c|c|c|}
\hline Lot No. & Provenience & Level & Comments \\
\hline $163-168$ & Area B, Unit 1 & $1,0-15 \mathrm{~cm}$ & \\
\hline $169-174$ & Area B, Unit 1 & $2,15-30 \mathrm{~cm}$ & \\
\hline $175-177$ & Area B, Unit 1 & $3,30-45 \mathrm{~cm}$ & \\
\hline $178-183$ & Area B, Unit 1 & $4,45-60 \mathrm{~cm}$ & \\
\hline $184-191$ & Backhoe Trench \#3 & - & Midden floor \\
\hline $192-197$ & N100 E133 & $1,0-15 \mathrm{~cm}$ & From mound surface \\
\hline $198-204$ & N100 E104 & $1,0-20 \mathrm{~cm}$ & From mound surface \\
\hline $205-212$ & N100 E104 & $2,20-35 \mathrm{~cm}$ & From mound surface \\
\hline $213-217$ & N100 E104 & $3,35-50 \mathrm{~cm}$ & From mound surface \\
\hline $218-221$ & N100 E104 & 4 & Clay cap \\
\hline 222 & N100 E104 & 5 & \\
\hline $223-226$ & N100 E108 & $85-100 \mathrm{~cm}$ & From mound surface \\
\hline $227-229$ & N100 E108 & $80-97 \mathrm{~cm}$ & From mound surface \\
\hline $230-233$ & N100 E108 & $97-127 \mathrm{~cm}$ & \\
\hline $234-236$ & N100 E108 & - & Midden surface \\
\hline $237-242$ & N100 E108 & - & $\begin{array}{l}\text { Midden surface to } 5 \mathrm{~cm} \\
\text { below midden surface }\end{array}$ \\
\hline $243-246$ & N100 E108 & $127-150 \mathrm{~cm}$ & \\
\hline $247-253$ & N100 E106 & 1 & From mound surface \\
\hline $254-262$ & N100 E106 & 2 & From mound surface \\
\hline $263-267$ & N100 E102 & $1,0-15 \mathrm{~cm}$ & From mound surface \\
\hline $268-269$ & N100 E102 & $7,95-110 \mathrm{~cm}$ & From mound surface \\
\hline $270-271$ & N100 E100 & $1,0-20 \mathrm{~cm}$ & From mound surface \\
\hline $272-277$ & N100 E100 & $2,20-35 \mathrm{~cm}$ & From mound surface \\
\hline $278-280$ & N100 E100 & $5,65-75 \mathrm{~cm}$ & From mound surface \\
\hline $281-282$ & N100 E104 & 6 & surface of clayey sub-mound \\
\hline $283-291$ & N100 E102 & $3,35-50 \mathrm{~cm}$ & From mound surface \\
\hline $292-296$ & N100 E102 & $2,20-35 \mathrm{~cm}$ & From mound surface \\
\hline $297-302$ & N100 E102 & $4,50-65 \mathrm{~cm}$ & From mound surface \\
\hline $303-308$ & N100 E102 & $5,65-80 \mathrm{~cm}$ & From mound surface \\
\hline $309-313$ & N100 E102 & $6,80-95 \mathrm{~cm}$ & From mound surface \\
\hline $314-320$ & N100 E106 & 3 & From mound surface \\
\hline $321-326$ & N100 E106 & $3,35-50 \mathrm{~cm}$ & From mound surface \\
\hline $327-337$ & N100 E100 & $4,50-65 \mathrm{~cm}$ & From mound surface \\
\hline
\end{tabular}




\begin{tabular}{llll} 
Lot No. & Provenience & Level & Comments \\
\hline 338 & N97 E111 & $1,0-5 \mathrm{~cm}$ & In trench floor \\
339 & N97 E111 & $1,0-5 \mathrm{~cm}$ & In trench floor \\
340 & N96 E117 & $1,0-20 \mathrm{~cm}$ & From mound surface \\
341 & N97 E111 & $2,5-10 \mathrm{~cm}$ & In trench floor \\
342 & N97 E111 & - & Midden in trench floor \\
343 & N97 E111 & $2,5-10 \mathrm{~cm}$ & In trench floor \\
344 & N97 E111 & $2,5-15 \mathrm{~cm}$ & In trench floor, east \\
345 & N97 E111 & $4,15-20 \mathrm{~cm}$ & In trench floor \\
346 & N95 E113 & $1,0-15 \mathrm{~cm}$ & In trench floor \\
347 & N96 E117 & 2 & From mound surface \\
348 & N97 E113 & $1,0-10 \mathrm{~cm}$ & In trench floor \\
349 & N97 E113 & - & Midden surface \\
350 & N97 E115 & $2,10-20 \mathrm{~cm}$ & In trench floor \\
351 & N97 E115 & $1,0-10 \mathrm{~cm}$ & In trench floor \\
353 & N95 E115 & -- & Trench profile \\
& N05 E115 & $1,0-10$ & In trench floor \\
\hline
\end{tabular}





\section{Appendix 2, Radiocarbon Analysis Forms}





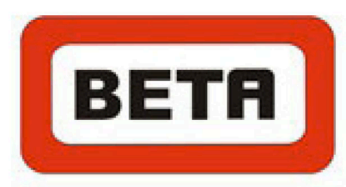

Consistent Accuracy ... ... Delivered On-time
Beta Analytic Inc.

August 15, 2011

Dr. Timothy K. Perttula

Archeological \& Environmental Consultants, LLC

10101 Woodhaven Drive

Austin, TX 78753

USA

RE: Radiocarbon Dating Results For Samples HS12-1, HS12-2, UR315-1, UR315-2

Dear Tim:

Enclosed are the radiocarbon dating results for four samples recently sent to us. They each provided plenty of carbon for accurate measurements and all the analyses proceeded normally. The report sheet also contains the method used, material type, and applied pretreatments and, where applicable, the two-sigma calendar calibration range.

As always, this report has been both mailed and sent electronically. All results (excluding some inappropriate material types) which are less than about 20,000 years BP and more than about $\sim 250 \mathrm{BP}$ include this calendar calibration page (also digitally available in Windows metafile (wmf) format upon request). The calibrations are calculated using the newest (2004) calibration database with references quoted on the bottom of each page. Multiple probability ranges may appear in some cases, due to shortterm variations in the atmospheric $14 \mathrm{C}$ contents at certain time periods. Examining the calibration graphs will help you understand this phenomenon. Don't hesitate to contact us if you have questions about calibration.

We analyzed these samples on a sole priority basis. No students or intern researchers who would necessarily be distracted with other obligations and priorities were used in the analyses. We analyzed them with the combined attention of our entire professional staff.

Information pages are also enclosed with the mailed copy of this report. If you have any specific questions about the analyses, please do not hesitate to contact us.

Thank you for prepaying the analyses. As always, if you have any questions or would like to discuss the results, don't hesitate to contact me.

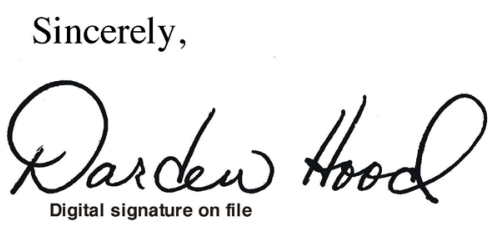




\section{REPORT OF RADIOCARBON DATING ANALYSES}

Dr. Timothy K. Perttula

Report Date: 8/15/2011

Archeological \& Environmental Consultants , LLC

Material Received: 8/8/2011

Sample Data

\author{
Measured \\ Radiocarbon Age
}

$13 \mathrm{C} / 12 \mathrm{C}$
Ratio

$-24.6 \mathrm{o} / \mathrm{oo}$

Beta - 303736

SAMPLE : HS12-1

ANALYSIS : AMS-Standard delivery

MATERIAL/PRETREATMENT : (plant material): acid/alkali/acid

2 SIGMA CALIBRATION :

Cal AD 1040 to 1100 (Cal BP 910 to 850) AND Cal AD 1120 to 1220 (Cal BP 830 to 730)

Beta - 303737

$890+/-30$ BP

$-22.5 \mathrm{o} / 00$

$930+/-30 \mathrm{BP}$

SAMPLE : HS12-2

ANALYSIS : AMS-Standard delivery

MATERIAL/PRETREATMENT : (plant material): acid/alkali/acid

2 SIGMA CALIBRATION : $\quad$ Cal AD 1030 to 1170 (Cal BP 920 to 780 )

Beta - 303738

$380+/-30 \mathrm{BP}$

$-26.8 \mathrm{o} / \mathrm{oo}$

$350+/-30 \mathrm{BP}$

SAMPLE : UR315-1

ANALYSIS : AMS-Standard delivery

MATERIAL/PRETREATMENT : (organic material): acid/alkali/acid

2 SIGMA CALIBRATION : $\quad$ Cal AD 1450 to 1640 (Cal BP 500 to 310)

Beta - 303739

$350+/-30 \mathrm{BP}$

$-26.1 \mathrm{o} / 00$

$330+/-30 \mathrm{BP}$

SAMPLE : UR315-2

ANALYSIS : AMS-Standard delivery

MATERIAL/PRETREATMENT : (organic material): acid/alkali/acid

2 SIGMA CALIBRATION : $\quad$ Cal AD 1460 to 1650 (Cal BP 490 to 300)

Dates are reported as RCYBP (radiocarbon years before present, "present" = AD 1950). By international convention, the modern reference standard was $95 \%$ the $14 \mathrm{C}$ activity of the National Institute of Standards and Technology (NIST) Oxalic Acid (SRM 4990C) and calculated using the Libby $14 \mathrm{C}$ half-life (5568 years). Quoted errors represent 1 relative standard deviation statistics (68\% probability) counting errors based on the combined measurements of the sample, background, and modern reference standards. Measured $13 \mathrm{C} / 12 \mathrm{C}$ ratios (delta $13 \mathrm{C}$ ) were calculated relative to the PDB-1 standard.
The Conventional Radiocarbon Age represents the Measured Radiocarbon Age corrected for isotopic fractionation, calculated using the delta $13 \mathrm{C}$. On rare occasion where the Conventional Radiocarbon Age was calculated using an assumed delta $13 \mathrm{C}$, the ratio and the Conventional Radiocarbon Age will be followed by "*". The Conventional Radiocarbon Age is not calendar calibrated. When available, the Calendar Calibrated result is calculated from the Conventional Radiocarbon Age and is listed as the "Two Sigma Calibrated Result" for each sample. 


\section{CALIBRATION OF RADIOCARBON AGE TO CALENDAR YEARS}

\section{(Variables: $\mathrm{C} 13 / \mathrm{C} 12=-24 \cdot 6: 1 \mathrm{ab} . \mathrm{mult}=1)$}

Laboratory number: Beta-303736

Conventional radiocarbon age: $\quad 880 \pm 30 \mathrm{BP}$

2 Sigm a calibrated results: Cal AD 1040 to 1100 (Cal BP 910 to 850) and

(95\% probability) Cal AD 1120 to 1220 (Cal BP 830 to 730)

Intercept data

Intercept of radiocarbon age

with calibration curve: Cal AD 1170 (Cal BP 780)

1 Sigma calibrated result: Cal AD 1160 to 1210 (Cal BP 800 to 740)

(68\% probability)

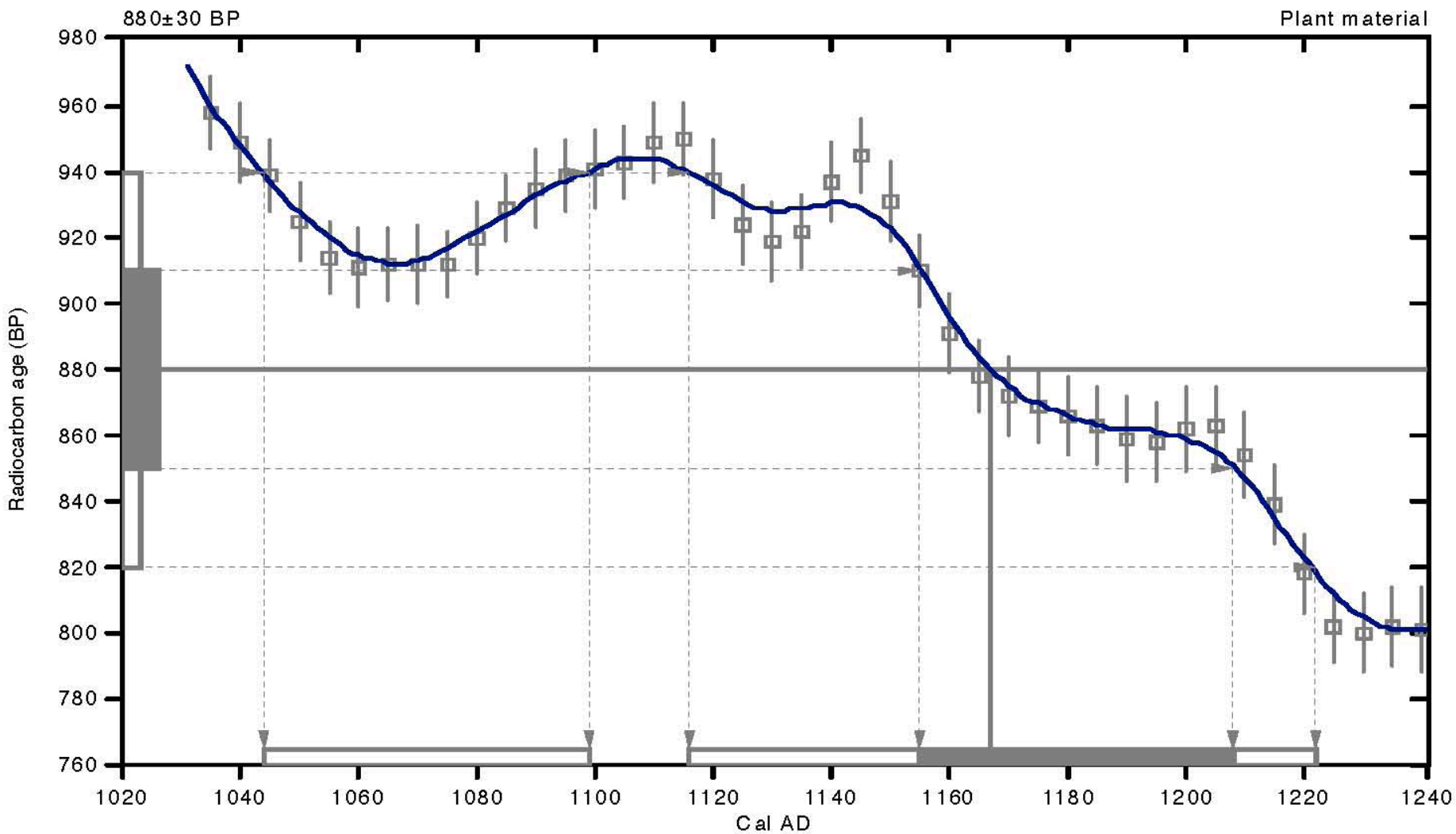

References:

Database used

INTCALO4

Calibration Database

INTCALO4 Radiocarbon Age Calibration

IntCal04: Calibration Issue of Radiocarbon (Volume 46, $n r$ 3, 2004).

Mathematics

A Simplified Approach to Calibrating C14 Dates

Talma, A.S., Vogel, J. C., 1993, Radiocarbon 35(2), p317-322 


\section{CALIBRATION OF RADIOCARBON AGE TO CALENDAR YEARS}

(V ariables: C13/C12 $=-22.5: 1 \mathrm{ab} . \mathrm{mult}=1)$

Laboratory number: Beta-303737

Conventional radiocarbon age: $930 \pm 30 \mathrm{BP}$

2 Sigm a calibrated result: Cal AD 1030 to 1170 (Cal BP 920 to 780 )

(95\% probability)

Intercept data

Intercepts of radiocarbon age

with calibration curve: Cal AD 1050 (Cal BP 900) and

Cal AD 1090 (Cal BP 860) and

Cal AD 1130 (Cal BP 820) and

Cal AD 1140 (Cal BP 810) and

Cal AD 1140 (Cal BP 810)

1 Sigma calibrated result: Cal AD 1040 to 1160 (Cal BP 920 to 790)

(68\% probability)

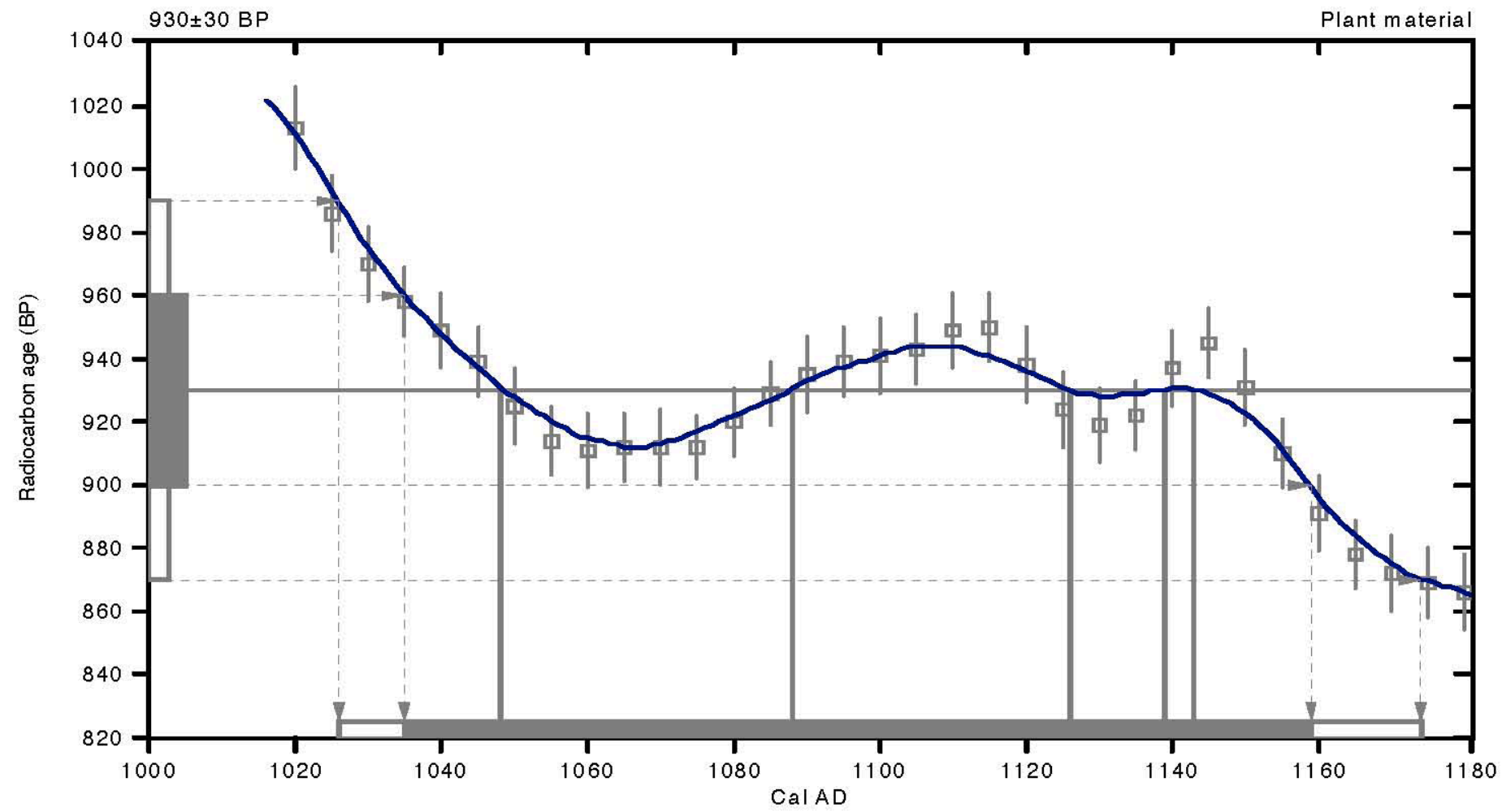

References:

Database used

INTCALO4

Calibration Database

INTCAL04 Radiocarbon Age Calibration

Int Cal04: Calibration Issue of Radiocarbon (Volume 46, $\mathrm{nr} 3,2004$ ).

Mathematics

A Simplified Approach to Calibrating C14 Dates

Talma, A.S., Vogel, J. C., 1993, Radiocarbon 35(2), p317-322 


\section{Appendix 3, Detailed Analysis of a Sample of Plain Sherds from the Mound Pond Site (41HS12)}

\section{P. Shawn Marceaux}

Plain Sherds from the Mound Deposits at the Mound Pond site (41HS12)

\begin{tabular}{|c|c|c|c|c|c|c|c|}
\hline \multicolumn{8}{|c|}{ Rim } \\
\hline Lot & Temper/Paste & $\begin{array}{l}\text { Surface } \\
\text { Treatment }\end{array}$ & $\begin{array}{c}\text { Firing } \\
\text { Conditions }\end{array}$ & $\begin{array}{l}\text { Thickness } \\
(\mathrm{mm})\end{array}$ & $\begin{array}{l}\text { Rim form- } \\
\text { Lip form }\end{array}$ & $\begin{array}{c}\text { Orifice } \\
\text { Diameter }(\mathrm{cm})\end{array}$ & $\begin{array}{l}\text { Vessel } \\
\text { Form }\end{array}$ \\
\hline 305 & grog & I SM & B & 4.7 & D-Rn & 15 & \\
\hline 305 & bone & & $\mathrm{F}$ & 4.0 & D-Th & $25+$ & \\
\hline 275 & grog & & B & 5.4 & Inv-Rn & $20+$ & \\
\hline 258 & bone & I E SM & $\mathrm{F}$ & 5.4 & D-Rn & $25+$ & \\
\hline 232 & grog & & $\mathrm{F}$ & 8.7 & D-Flat & & \\
\hline 71 & bone & I E SM & $\mathrm{G}$ & 5.5 & D-Rn & & \\
\hline 208 & bone-grog & E SM & $\mathrm{C}$ & 4.5 & D-Rn & 8 & BT \\
\hline 208 & grog & & $\mathrm{G}$ & 6.2 & $-\mathrm{Rn}$ & & \\
\hline 258 & grog & & $\mathrm{E}$ & 7.6 & D-Flat & & \\
\hline 232 & bone-grog & I E SM & $\mathrm{F}$ & 8.2 & $-\mathrm{Rn}$ & & \\
\hline 208 & grog & E SM & $\mathrm{C}$ & 5.5 & $-\mathrm{Rn}$ & & \\
\hline 250 & grog & & $\mathrm{H}$ & 7.3 & $-\mathrm{Rn}$ & & \\
\hline 220 & grog & I E SM & $\mathrm{E}$ & 6.9 & D-Flat & & \\
\hline 258 & bone-grog & E SM & $\mathrm{C}$ & 5.7 & $-\mathrm{Rn}$ & & \\
\hline 288 & bone-grog & & $\mathrm{F}$ & 5.2 & $-\mathrm{Rn}$ & & \\
\hline 288 & grog & & G & 3.9 & $-\mathrm{Rn}$ & & \\
\hline 305 & grog & & B & 6.1 & $\mathrm{D}-\mathrm{Rn}$ & & \\
\hline 323 & grog & & $\mathrm{F}$ & 6.6 & D-Rn & & \\
\hline 323 & bone-grog & & $\mathrm{G}$ & 8.3 & D-Flat & & \\
\hline 318 & bone & & $\mathrm{G}$ & 6.9 & $-\mathrm{Rn}$ & & \\
\hline 318 & bone-grog & & $\mathrm{F}$ & 6.9 & D-Rn & & \\
\hline 318 & bone-grog & & $\mathrm{G}$ & 6.5 & D-Rn & $10+$ & \\
\hline 294 & bone-grog & I E SM & A & 5.2 & -Flat & & \\
\hline 67 & grog & I E SM & $\mathrm{F}$ & 8.0 & D-Rn & $22+$ & \\
\hline
\end{tabular}


Body

\begin{tabular}{|c|c|c|c|c|c|}
\hline Lot & Temper/Paste & $\begin{array}{l}\text { Surface } \\
\text { Treatment }\end{array}$ & $\begin{array}{c}\text { Firing } \\
\text { Conditions }\end{array}$ & $\begin{array}{l}\text { Thickness } \\
(\mathrm{mm})\end{array}$ & Vessel Form \\
\hline 135 & grog-hematite & I SM & E & 7.5 & \\
\hline 294 & grog & I E SM & B & 6.7 & $\mathrm{CB}$ \\
\hline 47 & grog-hematite/sandy & I E SM & $\mathrm{F}$ & 8.3 & \\
\hline 310 & bone & I SM & $\mathrm{H}$ & 5.6 & \\
\hline 305 & bone-grog & E SM & $\mathrm{H}$ & 6.8 & \\
\hline 258 & grog & & $\mathrm{G}$ & 5.7 & $\mathrm{CB}$ \\
\hline 208 & grog & E SM & $\mathrm{F}$ & 6.9 & \\
\hline 250 & bone-grog & & B & 4.1 & \\
\hline 275 & grog & E SM & G & 6.0 & \\
\hline 159 & bone-grog & E SM & G & 4.7 & \\
\hline 154 & bone-grog & & $\mathrm{E}$ & 9.0 & \\
\hline 145 & grog & I E SM & $\mathrm{F}$ & 5.4 & \\
\hline 193 & grog & I E SM & $\mathrm{F}$ & 4.5 & \\
\hline 132 & grog-hematite & I SM & G & 6.7 & \\
\hline 275 & bone-grog & I E SM & $\mathrm{G}$ & 6.4 & \\
\hline 154 & grog & I E SM & $\mathrm{G}$ & 7.5 & \\
\hline 288 & bone-grog & & $\mathrm{F}$ & 6.0 & \\
\hline 154 & grog-hematite & & G & 4.7 & \\
\hline 250 & none/sandy & I E SM & A & 3.7 & \\
\hline 250 & grog & E SM & B & 4.5 & \\
\hline 154 & bone-grog & E SM & G & 5.8 & \\
\hline 130 & grog/sandy & I E SM & G & 7.7 & \\
\hline 232 & grog & I E SM & $\mathrm{H}$ & 4.2 & \\
\hline 258 & grog & I SM & K & 6.1 & \\
\hline 258 & bone-grog & I SM & $\mathrm{F}$ & 6.6 & \\
\hline 215 & grog & I E SM & B & 6.7 & \\
\hline 250 & bone-grog & I E SM & G & 6.0 & \\
\hline 224 & grog & I E SM & $\mathrm{F}$ & 7.6 & \\
\hline 215 & bone & I SM & $\mathrm{F}$ & 6.2 & \\
\hline 258 & grog & I E SM & $\mathrm{H}$ & 7.5 & \\
\hline 220 & bone-grog & I E SM & B & 7.2 & \\
\hline 220 & bone-grog & I E SM & A & 7.5 & \\
\hline 215 & bone & I E SM & G & 6.0 & \\
\hline
\end{tabular}




\begin{tabular}{|c|c|c|c|c|c|}
\hline 224 & bone-grog & I E SM & $\mathrm{A}$ & 4.9 & \\
\hline 215 & bone-grog & I E SM & $\mathrm{C}$ & 7.4 & \\
\hline 215 & bone-grog & I E SM & $\mathrm{C}$ & 6.7 & \\
\hline 244 & bone & I E SM & $\mathrm{F}$ & 7.4 & \\
\hline 244 & grog & I E SM & G & 10.2 & \\
\hline 288 & bone/sandy & & G & 6.0 & \\
\hline 288 & bone/sandy & I E SM & $\mathrm{L}$ & 3.5 & \\
\hline 288 & grog & & $\mathrm{E}$ & 6.5 & \\
\hline 288 & grog/sandy & & $\mathrm{H}$ & 3.7 & \\
\hline 288 & bone-grog & & A & 7.3 & \\
\hline 288 & bone & & A & 6.3 & \\
\hline 288 & grog & & B & 7.1 & $\mathrm{CB}$ \\
\hline 305 & grog & & $\mathrm{H}$ & 7.9 & \\
\hline 305 & bone-grog & I SM & $\mathrm{G}$ & 5.7 & \\
\hline 305 & grog & & B & 5.6 & \\
\hline 305 & bone-grog & I E SM & $\mathrm{J}$ & 5.2 & \\
\hline 305 & bone-grog & & $\mathrm{E}$ & 5.6 & \\
\hline 305 & bone-grog & I SM & G & 6.2 & \\
\hline 323 & grog & I E SM & G & 4.5 & \\
\hline 323 & bone-grog & & A & 7.2 & \\
\hline 323 & grog & I E SM & $\mathrm{E}$ & 10.4 & \\
\hline 323 & bone-grog & & $\mathrm{F}$ & 6.4 & \\
\hline 159 & grog-hematite & E SM & A & 5.9 & \\
\hline 159 & grog & & $\mathrm{F}$ & 7.8 & \\
\hline 159 & grog & I E SM & B & 4.1 & \\
\hline 159 & grog & I E SM & B & 7.6 & \\
\hline 159 & bone & I SM & G & 5.7 & \\
\hline 318 & bone & & $\mathrm{F}$ & 5.1 & \\
\hline 318 & none/sandy & & A & 6.1 & \\
\hline 318 & grog & & G & 7.4 & \\
\hline 318 & bone-grog & & G & 8.1 & \\
\hline 318 & bone-grog & E SM & D & 9.5 & \\
\hline 318 & grog & I E SM & B & 4.9 & \\
\hline 318 & grog & & A & 4.8 & \\
\hline 318 & bone-grog & & $\mathrm{F}$ & 6.6 & \\
\hline
\end{tabular}




\begin{tabular}{|c|c|c|c|c|c|}
\hline 318 & grog & E SM & $\mathrm{G}$ & 5.6 & \\
\hline 318 & bone-grog & & $\mathrm{C}$ & 5.9 & \\
\hline 318 & bone-grog & I E SM & $\mathrm{B}$ & 3.7 & $\mathrm{CB}$ \\
\hline 318 & bone-grog & & $\mathrm{F}$ & 5.7 & \\
\hline 318 & bone-grog & I SM & $\mathrm{B}$ & 6.0 & \\
\hline 333 & grog & & $\mathrm{E}$ & 6.8 & \\
\hline 333 & grog & & A & 8.1 & \\
\hline 333 & bone-grog & I E SM & $\mathrm{G}$ & 8.4 & \\
\hline 333 & bone-grog & I E SM & $\mathrm{F}$ & 7.0 & \\
\hline 333 & bone & I E SM & $\mathrm{F}$ & 4.1 & \\
\hline 333 & none/sandy & I SM & $\mathrm{F}$ & 4.0 & \\
\hline 333 & bone-grog & E SM & $\mathrm{H}$ & 6.3 & \\
\hline 333 & bone-grog & I E SM & $\mathrm{F}$ & 4.2 & \\
\hline 333 & bone & I SM & $\mathrm{F}$ & 5.1 & \\
\hline 333 & bone-grog & I E SM & $\mathrm{F}$ & 8.9 & \\
\hline 333 & bone-grog & I E SM & $\mathrm{F}$ & 8.4 & \\
\hline 333 & bone & & $\mathrm{A}$ & 4.7 & \\
\hline 333 & bone & I E SM & $\mathrm{B}$ & 5.1 & \\
\hline 310 & bone & E SM & G & 7.0 & \\
\hline 310 & bone & & G & 5.7 & \\
\hline 310 & bone-grog & E SM & $\mathrm{G}$ & 7.2 & \\
\hline 294 & bone-grog & I E SM & G & 5.7 & \\
\hline 294 & bone-grog & & $\mathrm{E}$ & 7.3 & \\
\hline 294 & bone-grog & & $\mathrm{E}$ & 7.2 & \\
\hline 294 & grog & I E SM & $\mathrm{F}$ & 4.4 & \\
\hline 300 & bone & & G & 6.1 & \\
\hline 300 & bone-grog & I SM & G & 7.1 & \\
\hline 300 & bone-grog & & G & 5.9 & \\
\hline 300 & bone-grog & I E SM & $\mathrm{F}$ & 5.1 & \\
\hline 300 & grog & & $\mathrm{F}$ & 6.0 & \\
\hline 347 & bone-grog & E SM & $\mathrm{H}$ & 6.5 & \\
\hline 151 & grog & & $\mathrm{E}$ & 7.1 & \\
\hline 340 & bone-grog & & G & 5.1 & \\
\hline 151 & grog & I E SM & $\mathrm{F}$ & 4.6 & \\
\hline 258 & grog & & $\mathrm{F}$ & 9.2 & \\
\hline
\end{tabular}




\begin{tabular}{|l|l|c|c|c|c|}
\hline 151 & grog & & G & 4.3 & \\
\hline 151 & grog & & E & 7.3 & \\
\hline 151 & bone-grog & & F & 6.5 & \\
\hline 340 & grog & & F & 7.0 & \\
\hline 265 & bone-grog & E SM & G & 7.7 & \\
\hline 288 & bone & E SM & A & 5.8 & \\
\hline 154 & grog & I E SM & B & 4.8 & \\
\hline 208 & grog & & E & 9.3 & \\
\hline 250 & grog & I SM & A & 7.8 & \\
\hline 208 & grog & I E SM & F & 6.5 & \\
\hline 135 & grog & I E SM & G & 7.4 & \\
\hline 135 & bone-grog & I E SM & B & 5.2 & \\
\hline 47 & grog & I E SM & E & 6.8 & \\
\hline 135 & grog & I E SM & E & 6.8 & \\
\hline
\end{tabular}

\section{Base}

\begin{tabular}{|c|c|c|c|c|}
\hline Lot & Temper/Paste & $\begin{array}{c}\text { Surface } \\
\text { Treatment }\end{array}$ & $\begin{array}{c}\text { Firing } \\
\text { Conditions }\end{array}$ & $\begin{array}{l}\text { Thickness } \\
\text { (mm) }\end{array}$ \\
\hline 47 & bone-grog & I E SM & G & 10.7 \\
\hline 300 & bone & & G & 8.4 \\
\hline 224 & grog & & $\mathrm{X}$ & 9.2 \\
\hline 159 & grog & E SM & $\mathrm{G}$ & 13.1 \\
\hline 288 & grog-hematite & & G & 10.7 \\
\hline 47 & bone-grog & I E SM & G & 12.0 \\
\hline 305 & grog-hematite & I E SM & B & 11.1 \\
\hline 300 & bone-grog & & G & 6.8 \\
\hline 294 & grog & I E SM & G & 13.1 \\
\hline 258 & grog & I E SM & $\mathrm{E}$ & 11.1 \\
\hline
\end{tabular}


Plain Sherds from the Sub-Mound Midden Deposits at the Mound Pond site

Rim

\begin{tabular}{|c|c|c|c|c|c|c|}
\hline Lot & Temper/Paste & $\begin{array}{c}\text { Surface } \\
\text { Treatment }\end{array}$ & $\begin{array}{c}\text { Firing } \\
\text { Conditions }\end{array}$ & $\begin{array}{l}\text { Thickness } \\
\text { (mm) }\end{array}$ & $\begin{array}{l}\text { Rim form- } \\
\text { Lip form }\end{array}$ & $\begin{array}{c}\text { Orifice } \\
\text { Diameter }(\mathrm{cm})\end{array}$ \\
\hline 138 & none/sandy & I E SM & G & 7.8 & Inv-Rn & $19+$ \\
\hline 349 & grog & I E SM & G & 9.5 & D-Rn & \\
\hline 189 & grog & I E SM & $\mathrm{F}$ & 9.6 & $\mathrm{D}-\mathrm{Rn}$ & \\
\hline 60 & grog & I E SM & B & 5.5 & D-Flat & \\
\hline 238 & grog & I E SM & B & 8.3 & D-Rn & \\
\hline 22 & grog & E SM & A & 7.4 & $-\mathrm{Rn}$ & \\
\hline 10 & grog & I E SM & I & 7.4 & D-Rn & \\
\hline 349 & grog & I E SM & B & 6.5 & $\mathrm{D}-\mathrm{Rn}$ & \\
\hline 10 & grog & I E SM & B & 4.6 & -Flat & \\
\hline 353 & bone-grog & I E SM & $\mathrm{F}$ & 6.8 & $-R n$ & \\
\hline 350 & grog & I E SM & B & 4.8 & D-Rn & \\
\hline 138 & grog & I E SM & A & 10.0 & -Flat & \\
\hline 3 & bone-grog & I SM & $\mathrm{X}$ & 7.6 & $-\mathrm{Rn}$ & \\
\hline 238 & bone-grog & E SM & G & 5.0 & $-\mathrm{Rn}$ & \\
\hline 98 & bone-grog & I SM & G & 5.1 & -Flat & \\
\hline 80 & grog-hematite & I E SM & B & 7.6 & D-Th & 15 \\
\hline 89 & grog & I E SM & B & 6.5 & $\begin{array}{c}\text {-Rn and folded } \\
\text { outward }\end{array}$ & \\
\hline 353 & grog & I E SM & $\mathrm{F}$ & 3.8 & $-\mathrm{Rn}$ & \\
\hline 348 & bone-grog & & $\mathrm{H}$ & 5.5 & $-\mathrm{Rn}$ & \\
\hline 56 & grog & I E SM & I & 5.1 & D-Flat & 12 \\
\hline
\end{tabular}

Body

\begin{tabular}{|c|l|c|c|c|c|}
\hline Lot & Temper/Paste & $\begin{array}{c}\text { Surface } \\
\text { Treatment }\end{array}$ & $\begin{array}{c}\text { Firing } \\
\text { Conditions }\end{array}$ & Thickness (mm) & Vessel Form \\
\hline 55 & grog & I E SM & E & 5.1 & \\
\hline 189 & grog-hematite & I E SM & E & 5.3 & \\
\hline 189 & grog & I E SM & F & 7.7 & \\
\hline 119 & grog-hematite & I E SM & G & 4.6 & \\
\hline 80 & grog & I E SM & B & 6.5 & CB \\
\hline 140 & grog & I E SM & F & 5.2 & CB \\
\hline 189 & grog & IE SM & E & 5.5 & \\
\hline 189 & grog & I E SM & G & 9.1 & \\
\hline 10 & grog & I E SM & G & 7.0 & \\
\hline
\end{tabular}




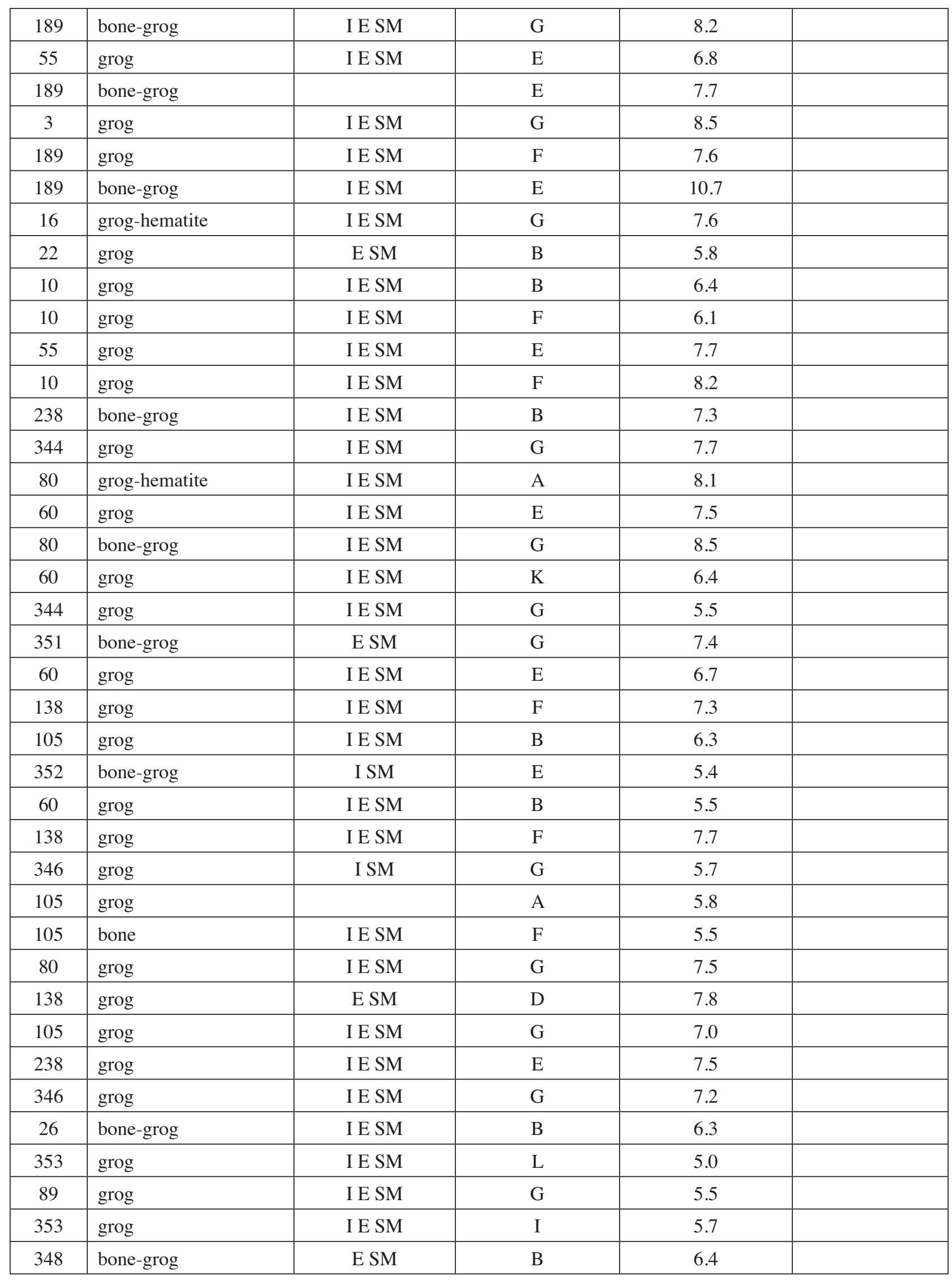




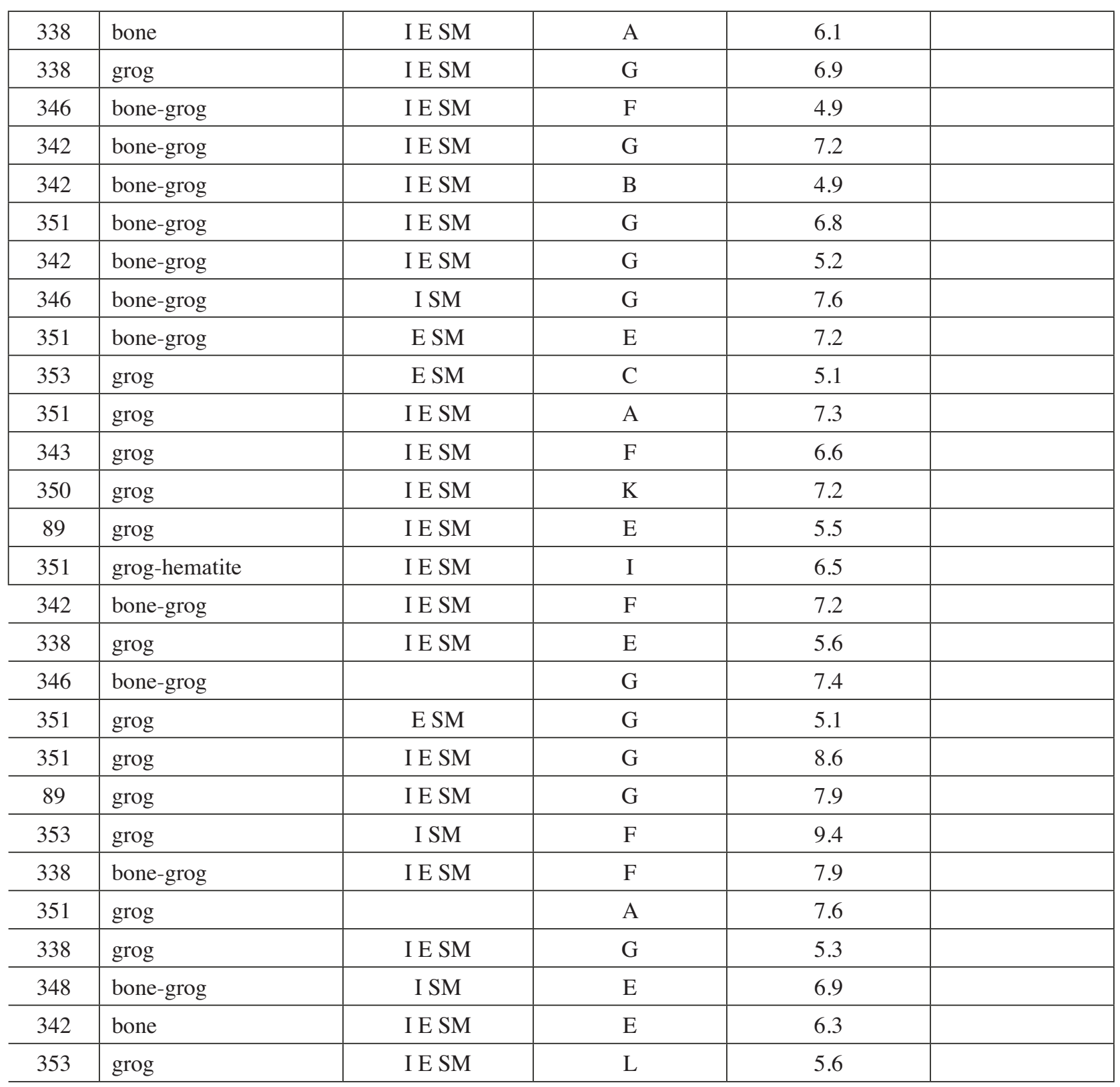

\section{Base}

\begin{tabular}{|c|c|c|c|c|}
\hline Lot & Temper/Paste & $\begin{array}{c}\text { Surface } \\
\text { Treatment }\end{array}$ & $\begin{array}{c}\text { Firing } \\
\text { Conditions } \\
\end{array}$ & Thickness (mm) \\
\hline 89 & grog & I E SM & E & 16.8 \\
\hline 89 & grog & I E SM & $\mathrm{E}$ & 17.9 \\
\hline 338 & bone-grog & I E SM & E & 17.0 \\
\hline 343 & grog & I E SM & B & 8.3 \\
\hline 75 & grog & I E SM & $\mathrm{E}$ & 13.0 \\
\hline
\end{tabular}


Plain Sherds from Area B at the Mound Pond site (41HS12)

Body

\begin{tabular}{|c|l|c|c|c|}
\hline \multicolumn{2}{|l}{ Lot } & \multicolumn{1}{c}{$\begin{array}{c}\text { Surface } \\
\text { Treatment }\end{array}$} & $\begin{array}{c}\text { Firing } \\
\text { Conditions }\end{array}$ & Thickness (mm) \\
\hline 176 & grog & I E SM & I & 6.4 \\
\hline 167 & grog & & B & 9.0 \\
\hline 176 & bone & I SM & F & 6.5 \\
\hline 176 & bone-grog & I SM & C & 7.6 \\
\hline 176 & bone-grog & & C & 6.1 \\
\hline 176 & bone-grog & & C & 6.6 \\
\hline 176 & bone-grog & I SM & A & 6.2 \\
\hline 181 & grog & I E SM & F & 5.7 \\
\hline 173 & grog & I SM & F & 4.0 \\
\hline 176 & grog & I SM & B & 5.2 \\
\hline 173 & grog & I E SM & I & 4.5 \\
\hline 167 & bone-grog & I E SM & C & 4.6 \\
\hline 176 & grog & & F & 6.2 \\
\hline 181 & bone-grog & & B & 5.3 \\
\hline 167 & grog & & & \\
\hline
\end{tabular}





\section{Appendix 4, Detailed Analysis of Decorated Sherds from the Mound Pond Site (41HS12)}

Timothy K. Perttula

\begin{tabular}{|c|c|c|c|c|c|c|}
\hline $\begin{array}{l}\text { Lot } \\
\text { No. }\end{array}$ & Sherd Type & Temper & $\mathrm{FC}$ & $\begin{array}{l}\mathrm{ST} \\
(\mathrm{mm})\end{array}$ & $\mathrm{Th}$ & Decoration \\
\hline \multicolumn{7}{|c|}{ Mound Deposits } \\
\hline 071 & body & grog & $\mathrm{F}$ & I SM & 5.9 & $\begin{array}{l}\text { V-shaped punctations } \\
\text { and parallel incised } \\
\text { lines }\end{array}$ \\
\hline 136 & rim & grog & $\mathrm{B}$ & $\mathrm{I} / \mathrm{E} \mathrm{B}$ & 5.1 & $\begin{array}{l}\text { Crockett Curvilinear } \\
\text { Incised; } 13 \mathrm{~cm}+\text { OD }\end{array}$ \\
\hline 150 & body & grog & G & $\begin{array}{l}\mathrm{I} / \mathrm{E} \\
\mathrm{SM}\end{array}$ & 5.6 & Holly Fine Engraved \\
\hline 150 & rim & grog & $\mathrm{F}$ & E B & 6.7 & Holly Fine Engraved \\
\hline 155 & body & grog & $\mathrm{B}$ & - & 6.0 & $\begin{array}{l}\text { parallel-diagonal } \\
\text { incised lines }\end{array}$ \\
\hline 155 & rim & grog & $\mathrm{F}$ & I SM & 7.3 & $\begin{array}{l}\text { tool punctated rows } \\
\text { with diagonal incised } \\
\text { lines between; } 13+\mathrm{cm} \\
\text { OD }\end{array}$ \\
\hline 155 & rim & grog & $\mathrm{F}$ & I SM & 5.5 & diagonal incised lines; $15+\mathrm{cm}$ OD \\
\hline 203 & $\begin{array}{l}\text { lower rim- } \\
\text { body }\end{array}$ & grog-bone & $\mathrm{F}$ & - & 9.7 & $\begin{array}{l}\text { collared rim with diagonal } \\
\text { incised lines; fingernail } \\
\text { punctated rows on body; } \\
16 \mathrm{~cm} \text { OD }\end{array}$ \\
\hline 204 & body & grog & $\mathrm{F}$ & - & 8.1 & free fingernail punctates \\
\hline 209 & rim & grog-bone & $\mathrm{F}$ & - & 7.2 & $\begin{array}{l}\text { diagonal-horizontal incised } \\
\text { panels; } 26 \mathrm{~cm} \mathrm{OD}\end{array}$ \\
\hline 209 & rim & grog & $\mathrm{F}$ & - & 7.5 & $\begin{array}{l}\text { horizontal incised lines; } 19 \\
\text { cm OD }\end{array}$ \\
\hline 209 & rim & grog-bone & $\mathrm{F}$ & - & 6.7 & $\begin{array}{l}\text { Holly Fine Engraved; } 18 \mathrm{~cm} \\
\text { OD }\end{array}$ \\
\hline 216 & body & grog & $\mathrm{B}$ & - & 6.0 & opposed incised lines \\
\hline 216 & body & $\begin{array}{l}\text { grog- } \\
\text { hematite-SP }\end{array}$ & $\mathrm{K}$ & - & 7.2 & free fingernail punctates \\
\hline 225 & rim & grog & A & $\mathrm{I} / \mathrm{E} \mathrm{B}$ & 5.4 & $\begin{array}{l}\text { band punctated; } 11 \mathrm{~cm} \mathrm{OD;} \\
\mathrm{CB}\end{array}$ \\
\hline 229 & body & grog & $\mathrm{F}$ & I SM & 7.0 & V-shaped punctated rows \\
\hline 233 & rim & grog & $\mathrm{F}$ & E SM & 6.5 & $\begin{array}{l}\text { horizontal and diagonal } \\
\text { engraved lines; red pigment }\end{array}$ \\
\hline 250 & body & grog & $\mathrm{F}$ & - & 7.8 & cross-hatched incised; CB \\
\hline 251 & body & grog & B & I SM & 6.4 & $\begin{array}{l}\text { vertical punctations and } \\
\text { incised chevron }\end{array}$ \\
\hline
\end{tabular}




\begin{tabular}{|c|c|c|c|}
\hline Lot & Sherd Type & Temper & $\mathrm{FC}$ \\
\hline
\end{tabular}

\section{Mound Deposits, cont.}

259 rim

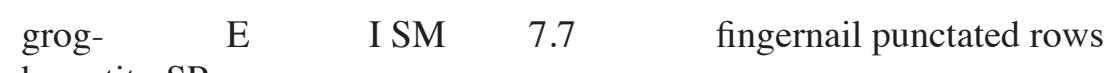

\begin{tabular}{|c|c|c|c|c|c|c|}
\hline & & gios & & & & above tool punctated zone \\
\hline 259 & rim & grog & $\mathrm{G}$ & I SM & 6.2 & $\begin{array}{l}\text { tool punctated rows with } \\
\text { horizontal incised lines } \\
\text { between: } 15+\mathrm{cm} \mathrm{OD}\end{array}$ \\
\hline 259 & body & grog & $\mathrm{G}$ & - & 6.6 & $\begin{array}{l}\text { curvilinear incised zone } \\
\text { filled with triangular tool } \\
\text { punctates }\end{array}$ \\
\hline 276 & body & grog & A & I SM & 7.3 & triangular tool punctates \\
\hline 287 & rim & SP & $\mathrm{B}$ & I SM & 6.8 & $\begin{array}{l}\text { curvilinear incised zone } \\
\text { filled with small circular } \\
\text { punctations }\end{array}$ \\
\hline 295 & body & grog & $A$ & - & 6.0 & $\begin{array}{l}\text { vertical incised panels with } \\
\text { diagonal incised lines }\end{array}$ \\
\hline 295 & rim & bone & $\mathrm{F}$ & E SM & 7.2 & $\begin{array}{l}\text { horizontal and diagonal } \\
\text { hatched engraved lines }\end{array}$ \\
\hline 295 & rim & bone-grog & $\mathrm{H}$ & - & 7.1 & $\begin{array}{l}\text { horizontal incised lines; } 16 \mathrm{~cm}+ \\
\text { OD }\end{array}$ \\
\hline 295 & rim & grog & A & I SM & 6.9 & $\begin{array}{l}\text { tool punctated row under lip } \\
\text { and diagonal incised lines } \\
\text { on rim; } 28 \mathrm{~cm} \text { OD }\end{array}$ \\
\hline 305 & rim & grog-bone & $\mathrm{F}$ & - & 8.9 & horizontal incised lines \\
\hline
\end{tabular}

\section{Sub-Mound Midden Deposits}

\begin{tabular}{|c|c|c|c|c|c|c|}
\hline 090 & rim & grog & $\mathrm{G}$ & $\mathrm{I} / \mathrm{E} \mathrm{B}$ & 6.3 & $\begin{array}{l}\text { Coles Creek Incised; } 32 \mathrm{~cm} \\
\text { OD; CB }\end{array}$ \\
\hline 239 & body & grog & $\mathrm{F}$ & I SM & 9.2 & diagonal opposed incised lines \\
\hline 338 & rim & grog & $\mathrm{B}$ & - & 7.1 & $\begin{array}{l}\text { horizontal incised lines; } 14+ \\
\text { cm OD }\end{array}$ \\
\hline 338 & rim & grog/SP & $\mathrm{B}$ & $\mathrm{I} / \mathrm{E} \mathrm{B}$ & 7.6 & Coles Creek Incised; $27 \mathrm{~cm}$ OD \\
\hline 346 & body & grog & $\mathrm{L}$ & $\begin{array}{l}\text { E B/ } \\
\text { I SM }\end{array}$ & 6.9 & Coles Creek Incised \\
\hline 349 & body & grog & $\mathrm{F}$ & - & 7.0 & Coles Creek Incised \\
\hline 349 & rim & grog & $\mathrm{F}$ & - & 9.7 & Coles Creek Incised; $24 \mathrm{~cm}$ OD \\
\hline 351 & body & grog-bone & A & I SM & 5.5 & Coles Creek Incised \\
\hline 351 & rim & grog & $\mathrm{B}$ & $\begin{array}{l}\mathrm{I} / \mathrm{E} \\
\mathrm{SM}\end{array}$ & 8.8 & $\begin{array}{l}\text { Coles Creek Incised, var. } \\
\text { Coles Creek; } 19 \mathrm{~cm} \text { OD }\end{array}$ \\
\hline 351 & body & grog & $\mathrm{B}$ & I SM & 8.0 & parallel pinched ridges \\
\hline
\end{tabular}


$\begin{array}{llllll}\text { Lot } & \text { Sherd Type } & \text { Temper } & \text { FC } & \begin{array}{l}\text { ST } \\ (\mathrm{mm})\end{array} & \text { Th }\end{array}$

\section{Sub-Mound Midden Deposits, cont.}

$\begin{array}{lllllll}351 & \begin{array}{l}\text { lower rim- } \\ \text { body }\end{array} & \text { grog } & \text { B } & \text { E B/ } & 7.9 & \text { Coles Creek Incised } \\ 351 & \text { body } & \text { grog } & \text { G } & \text { I/E B } & 4.9 & \text { curvilinear engraved lines } \\ 353 & \text { rim } & \text { grog } & \text { B } & \text { I SM } & 6.4 & \text { Coles Creek Incised; 19 cm OD } \\ 353 & \text { rim } & \text { grog } & \text { H } & \text { I SM } & 7.2 & \text { Coles Creek Incised; } 14 \mathrm{~cm}+\text { OD }\end{array}$

No Provenience



SP=sandy paste; FC=firing conditions; A-L designations follow Teltser (1993:Figure 2a-h) and Perttula (2005:Figure 5-30i-1);

$\mathrm{ST}=$ surface treatment: $\mathrm{I}=$ interior; $\mathrm{E}=$ exterior; $\mathrm{SM}=$ smoothed; $\mathrm{B}=$ burnished; Th=thickness; $\mathrm{OD}=$ orifice diameter; $\mathrm{CB}=$ carinated bowl 
